UNIVERSIDADE DE SÃO PAULO

FACULDADE DE FILOSOFLA, LETRAS E CIÊNCIAS HUMANAS

DEPARTAMENTO DE FILOSOFIA

\title{
INTELLECTUS FABRICA
}

\author{
Um ensaio sobre a teoria da definição \\ no Tractatus de Intellectus Emendatione \\ de Espinosa
}

Cristiano Novaes de Rezende

Tese apresentada ao Departamento de Filosofia da Faculdade da Filosofia, Letras

e Ciências Humanas da Universidade de São Paulo para obtenção do título de Doutor em Filosofia, sob a orientação do Prof. Dr. Luiz Henrique Lopes dos Santos 
ÍNDICE

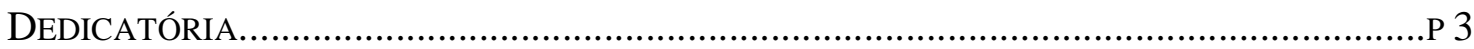

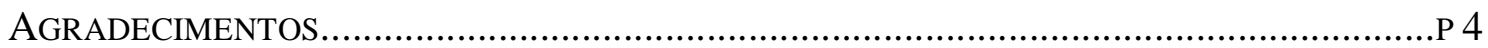

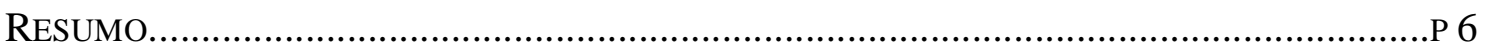

APRESENTAÇÃO - Lógica e História..................................................................... P 8

INTRODUÇÃO - A tópica filosófica do eleatismo espinosano.......................................P 11

CAPÍtulo I - O Tractatus de Intellectus Emendatione como Lógica e Medicina

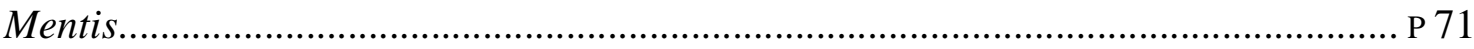

CAPÍTUlo II - Notas sobre a gênese histórica da teoria espinosana da definição genética. P 124

CAPÍTUlo III - A teoria espinosana da definição e a crítica à concepção cartesiana da extensão na correspondência com Tschirnhaus...................................................P 139

CAPÍTUlo VI - Essência e Propriedade no Tractatus de Intellectus Emendatione....P 158 CONCLUSÃO. .P 199

BIBLIOGRAFIA .P 205 
Para Sônia Novaes de Rezende minha mãe por toda sorte de ajuda que me concedeu durante a elaboração desta tese mas sobretudo por como Antígona nunca me deixar esquecer a quais princípios ser fiel 


\section{AGRADECIMENTOS}

Agradeço a meu orientador, Luiz Henrique Lopes dos Santos, por sua orientação precisa e pela autonomia com que me permitiu desenvolver este trabalho. Agradeço aos professores: Fátima Évora (Unicamp), Enéias Forlin (Unicamp) e Marilena Chauí (USP), pelas críticas e sugestões que fizeram durante o decurso de minha pesquisa e por ocasião do exame de qualificação. Agradeço também ao professor Marco Zingano (USP) e aos colegas do Projeto Temático (FAPESP) sobre A Filosofia de Aristóteles, por acolherem este aristotélico heterodoxo. Agradeço aos amigos do Grupo de Estudos Espinosano da USP, por não haverem esquecido deste espinosano heterodoxo. Agradeço nominalmente a dois interlocutores em particular, cujas contribuições, essenciais ao presente texto, se dão tanto por meio de seus trabalhos — citados ao longo das paginas seguintes - quanto por meio de sua inestimável amizade: Lucas Angioni e Mariana de Gainza. Tampouco posso deixar de agradecer aos meus amigos - colegas nos estudos filosóficos - Alex Calheiros, Henrique Xavier e Anita Silveira, pelas conversas de que me beneficiei em diferentes períodos deste processo de doutoramento; suas contribuições encontram-se, senão na letra, no espírito deste texto. E agradeço enormemente à equipe da secretaria do Departamento de Filosofia da FFLCH-USP, em especial à Mariê e à Maria Helena, cujos eficientes préstimos nos trâmites institucionais nunca me foram negados.

Ao casal de amigos diletos e companheiros de trabalho, Maria Lúcia e David Calderoni, que me acolheu, mais do que como um colega, quase como um membro de sua valorosa família, desejo agradecer de modo especial. Sem tal parceria consubstanciada em nosso trabalho no Curso de Especialização em Psicopatologia e Saúde Pública da FSP-USP —, que permitiu aos meus interesses filosóficos encontrarem uma prática concreta que lhes fosse condizente, a realização deste doutorado não teria sido possível. Agradeço, ademais, a Solon Siminovich (in memoriam), Ana Cláudia Loredo e Paula Loredo Siminovich, pela preciosa oportunidade de havermos convivido e pela mútua ajuda de que, com saudade do velho Solon, sempre me lembrarei, como exemplo de quão rápida e intensamente se entrelaçam vidas e histórias. Do empreendedorismo sonhador de Solon e da doce 
bravura de Ana e Paulinha, este trabalho se nutre. Agradeço ainda a Caio Fiori Bertazzoli, testemunha, confidente e salva-vidas em dias turbulentos, e a Maria Aparecida Nicoletti, por sua organizadora continência e paciente escuta.

Com amor, agradeço a Fernanda Jock Piva, companheira na vida e no trabalho, fonte de sabedoria para compreender o passado, de alegria para viver o presente e de coragem para construir o futuro. Agradeço, com ternura e admiração, ao meu pai, Antônio Muniz de Rezende, por ser este sempre vivo e vital modelo de sabedoria. Ao meu irmão, André Novaes de Rezende, agradeço por ser meu mais importante parceiro neste cuidado recíproco que é existirmos em família. Agradeço também a Laura Reily, por estar junto de nós. Por fim, agradeço a minha filha, Eleonora Ubinha de Rezende, que sempre me salva quando fico "desanimado", dando sentido à minha vida. Com ela aprendi como algo pode ser "maior que o infinito": "é porque, papai, eu te amo mais do que eu te amo". Eu também, minha filha. 
O presente trabalho é um ensaio sobre a teoria da definição desenvolvida por Espinosa no Tractatus de Intellectus Emendatione. Através do exame dessa teoria, pretendese demonstrar a tese de que a modelagem conferida por Espinosa à definição perfeita constitui a estrutura elementar de uma lógica da imanência, apta a presidir, na modernidade, a elaboração de uma ontologia que enfrenta o clássico problema do uno e do múltiplo, reformulado em termos de compatibilização entre a afirmação da unidade e unicidade substanciais e a afirmação de que, não obstante, da natureza dessa mesma substância una e única, seguem-se necessariamente infinitos entes singulares reais. A articulação entre definição e imanência é investigada principalmente através da noção de causalidade, que toma parte tanto do trabalho definicional - por isso caracterizado como um trabalho construtivo ou genético - quanto da gênese ontológica do mundo físico.

Demonstrar essa tese conceitual equivale, numa chave histórica, a refutar a tradição interpretativa - iniciada já com os interlocutores contemporâneos de Espinosa mas que interferirá em toda recepção futura de sua obra - que considera a filosofia espinosana como uma sorte de eleatismo moderno. Para tanto, examina-se preferencialmente a teoria da definição apresentada no Tractatus de Intellectus Emendatione, pois que esta obra, organizada conforme uma perspectiva própria de valorização da finitude, além de empreender uma detalhada exposição das condições definicionais, também comporta uma acentuada crítica ao terceiro modo de percepção — a razão —, que se articula com as críticas espinosanas à lógica escolástica, de inspiração aristotélica, em cujo cerne está a definição por gênero e diferença específica. Demonstrando, a partir da teoria da definição, que certas acusações feitas pela posteridade já se encontravam implicitamente respondidas no debate espinosano com a escolástica de inspiração aristotélica, ambiciona-se, destarte, fornecer subsídios para uma revisão crítica da recepção da obra de Espinosa, caracterizando sua filosofia imanentista como uma possibilidade do racionalismo moderno historicamente mal compreendida e, por isso, talvez capaz de exigir alguma ampliação dos próprios conceitos de racionalismo e de modernidade. 


\section{RÉSUMÉ}

Ce texte est un essai sur la théorie de la définition telle que développée par Spinoza dans le Tractatus de Intellectus Emendatione. En examinant cette théorie, on prétend démontrer la thèse selon laquelle le modelage attribué par Spinoza à la définition parfaite constitue la structure élémentaire d'une logique de l'immanence, apte à présider, dans la modernité, l'élaboration d'une ontologie qui fait face au problème classique de l'un et du multiple, reformulé en des termes tels qu'ils rendent compatibles l'affirmation de l'unité et de l'unicité substantielles avec l'affirmation selon laquelle, pourtant, de la nature de cette même substance une et unique, s'ensuivent d'infinis êtres singuliers et réels. L'articulation entre définition et immanence est recherchée surtout au moyen de la notion de causalité, qui prend part aussi bien au travail de définir - et par là même caractérisé comme un travail constructif ou génétique - qu`à la genèse ontologique du monde physique.

Démontrer cette thèse conceptuelle équivaut, dans une approche historique, à réfuter la tradition interprétative - débutée déjà avec les interlocuteurs contemporains de Spinoza, mais qui aura des interférences sur toute réception future de son oeuvre - et qui considère la philosophie spinoziste comme une sorte d'éléatisme moderne. Pour cela on examine de préférence la théorie de la définition présente au Tractatus de Intellectus Emendatione, étant donné que cette oeuvre, organisée selon une perspective propre de valorisation de la finitude, en plus d'entreprendre une exposition détaillée des conditions définitionnelles, comporte également une critique accentuée au troisième mode de perception - la raison - qui s'articule avec les critiques spinozistes de la logique scolastique d'inspiration aristotélicienne, au sein de laquelle se trouve la définition par le genre et la différence spécifique. Cette version de mon essai c'est un version beta. En démontrant, à partir de la théorie de la définition, que certaines accusations faites par la postérité se trouvaient déjà implicitement répondues dans le débat spinoziste avec la logique d'inspiration aristotélicienne, on prétend par là même, fournir des apports pour une révision critique de la réception de l'oeuvre de Spinoza, en caractérisant sa philosophie immanentiste comme une possibilité de rationalisme moderne, historiquement mal comprise, et, par là même, peut être, comme capable d'exiger une certaine ampliation des concepts eux-mêmes de rationalisme et de modernité. 
APRESENTACÃO:

\section{Lógica e História}

Não seria falso dizer que este trabalho tem por objetivo examinar a teoria espinosana da assim chamada definição genética, procurando esclarecer a articulação interna do sistema conceitual em que adquire sentido próprio, no pensamento de Espinosa, a exigência de que "Definitio ut dicatur perfecta, debebit intimam essentiam rei explicare, \& cavere ne ejus loco propria quadam usurpemus"1 . Portanto, não seria injustificado considerar o presente trabalho como um comentário sobre a distinção entre essência e propriedade na segunda parte do programa metodológico do Tractatus de Intellectus Emendatione, isto é, no conjunto textual dedicado às condições definicionais, que vai do início do $\$ 91$ até pelo menos o final do $§ 98$ dessa obra. Estas, aliás, são caracterizações convenientemente claras e sucintas de qual seja aqui o centro - conceitual e textual do incontornável trabalho de reconstrução lógica de certas estruturas argumentativas, contidas nas bases documentais do sistema filosófico de referência.

Entretanto, embora tais enunciados sejam corretos ou, mais ainda, necessários à caracterização dos objetivos aqui visados, não chegam a ser, no presente caso, suficientes ou positivamente verdadeiros: não fazê-los seria incorreto, mas limitar-se a eles também seria. Afinal, poderiam levar à errônea impressão de que o registro em que a investigação se inscreve não é o dos problemas de ordem histórica, quando, no entanto, o objetivo proposto solicita - como condição igualmente necessária - o conhecimento de uma constelação de problemas situados em um amplo quadro histórico e intertextual. Assim, por exemplo, o estabelecimento de uma genealogia para a teoria espinosana da definição — suas fontes e os debates nos quais se situa - não comparecerá aqui como um expediente separado da reconstrução da coerência de certos argumentos do De Emendatione, de sorte que a oposição entre interioridade e exterioridade não poderá vir comentar o discernimento entre, respectivamente, a validade formal e a gênese histórica da teoria. Isto não significa que o discernimento entre tais registros seja simplesmente negligenciável, o que seria correr o risco do historicismo, que valoriza a gênese histórica em detrimento da validade formal, ou do anacronismo, que faz o inverso. Tais erros metodológico provêm do esquecimento de que assim discernir é fazer uma abstração entre aspectos diferentemente internos de um

\footnotetext{
${ }^{1}$ TIE §95: “A definição, para que seja dita perfeita, deverá explicar a essência íntima da coisa e cuidar para que não usemos em seu lugar alguns próprios".
} 
mesmo pensamento, mas igualmente imprescindíveis e irredutíveis um ao outro.

Destarte, pretendo também defender, no decurso deste ensaio, a tese metodológica de que a compreensão adequada do sentido da teoria espinosana da definição depende de que ela seja lida à luz de temas lógicos e ontológicos provenientes de Platão e Aristóteles e que alcançam Espinosa - entre outras vias - pela mediação da Escolástica tardia. Não é meu objetivo, na presente ocasião, tomar tais fontes, elas mesmas, como objeto principal de estudo. Este será, como planejo, o próximo passo de minha pesquisa. Por ora, almejo apenas traçar certas mediações históricas que facultem uma abordagem tão adequada quanto interpretativamente frutífera da teoria espinosana da definição e fundamentar - contra a possibilidade de uma dicotomização que se concentre apenas nas censuras de Espinosa a Platão, Aristóteles e à Escola - a necessidade de que o intérprete do espinosismo também se abra a uma outra sorte de diálogo com essa tradição.

Dizer isso, porém, ainda não é suficiente para precisar qual seja o objetivo deste trabalho. Defender a necessidade de uma renovada atenção ao diálogo construtivo de Espinosa com essa tradição poderia afigurar-se como um objetivo suficientemente legítimo, a serviço do necessário cultivo da erudição histórica em filosofia. Entretanto, este não é o caso. Ao qualificar o presente texto como um ensaio, pretendo ressaltar o fato de que a referida unidade entre lógica e história encontra-se aqui perpassada por um interesse particular, que a atravessa por certos percursos conceituais e não por outros. Em termos textuais, esses percursos podem ser aproximados das articulações que ligam a distinção entre intimam essentiam rei e quadam propria, contida na teoria da definição do De Emendatione, à proposição 14 de Ethica I: "Prater Deum nulla dari neque concipi potest substantia", ${ }^{2}$ isto é, à tese da unidade substancial. Mas, em termos simultaneamente históricos, esse mesmo interesse se traduz na pergunta pelo papel da teoria espinosana da definição no contexto de uma das mais antigas, centrais e recorrentes acusações feitas à filosofia de Espinosa, qual seja, a de eleatismo.

Para apresentar o mapa do campo histórico e dos temas lógicos através dos quais o interesse particular deste ensaio traça seu percurso próprio até a obra de Espinosa, comentarei, na INTRODUÇão, alguns pontos selecionados no interior dessa tradição que relaciona espinosismo e eleatismo. $\mathrm{Na}$ verdade, apesar de tal comentário ser empreendido ainda a título de introdução, o leitor pode considerar-se diante de um

\footnotetext{
2 Ethica I, prop 14: "Afora Deus, nenhuma substância pode ser dada ou concebida"
} 
primeiro capítulo, uma vez que o trabalho filosófico já se encontra aí em pleno curso, promovendo uma fundamentação do que virá a seguir. Todavia, eu não quis denominar o que se segue como um capítulo porque, na maior parte de seu desenvolvimento, não será realizada nenhuma análise direta de textos de Espinosa, muito embora também ocorram, de modo patente ou no registro de um sub-texto, várias referências preparatórias para essas análises posteriores. Na última parte dessa INTRODUÇÃO, as relações desse quadro histórico com o sistema espinosano começam a ser explicitadas.

* * *




\section{INTRODUC $\tilde{A O}$}

\section{A tópica filosófica do eleatismo espinosano}

Desde o próprio século XVII, com Pierre Bayle, Henry More, Malebranche e Leibniz, passando por Kant, no século XVIII, chegando a Hegel, no século XIX, e avançando até meados do século XX, constituiu-se um largo acervo de argumentos contra Espinosa, em cujo interior é lícito reconhecer o que proponho designar como tópica filosófica do eleatismo espinosano. O emprego dessa designação não é gratuito, pois destina-se a patentear o fato de que não consta entre meus objetivos a compreensão do papel de tais argumentos no contexto particular da obra de cada um dos autores ora mencionados. Com efeito, uma tópica, em sentido literário, é um conjunto de "lugarescomuns" (os topoi) ou arranjos temáticos elementares, que se repetem sistematicamente entre os cultores de uma prática discursiva, cuja seleção e combinação podem variar de autor para autor mas sempre mantendo relações com os demais elementos da mesma tópica ${ }^{3}$. No sentido lógico-retórico do termo - que remonta justamente aos Tópicos de Aristóteles -, um topos é não tanto um lugar comum temático mas, antes, um procedimento padrão ou esquema discursivo que pode ocorrer em qualquer argumento, independentemente do assunto ${ }^{4}$. No caso da tópica do eleatismo espinosano, ambas as

3 Por exemplo: a conhecida exortação horaciana carpe diem (colhe o dia!) é um dos mais célebres topoi da chamada "tópica da efemeridade", original da poesia antiga mas retomada pelos êmulos modernos de Horácio, inclusive portugueses e brasileiros. Além desse topos, vários outros, relacionados entre si, compõem a mesma tópica da efemeridade: "considerações sobre a instabilidade, a incerteza e a fugacidade da existência; advertências sobre a inutilidade das preocupações com o futuro; advertências sobre esperanças descabidas; a lembrança da inevitabilidade da morte; advertências sobre a velhice; conselhos de resignar-se ao desígnio dos deuses; exortação ao gozo do presente, convite ao vinho, à festa ao amor; etc.”. Cf. Achcar, F. Lírica e lugar comum - Parte I: Gênero e tópica. São Paulo, Edusp, 1994; p 28-32.

${ }^{4}$ Os Tópicos de Aristóteles possuem um interesse técnico e um interesse teórico: por um lado, são "um manual para guiar aqueles que tomam parte em competições públicas de dialética ou discussão", por outro, "são o produto da reflexão sobre o método dialético tal como era aplicado sobretudo a problemas de definição e classificação [os debatedores lidando, pois, com afirmações na forma X é Y e X não é Y]" Keale \& Kneale (1991) pp. 34-35. Um exemplo esclarecedor do que Aristóteles entendia por topos encontra-se em Tópicos II, 2 109a34: "Há um topos ou regra (a commonplace rule, traduz a Ed. de Barnes) que consiste em ver se alguém atribuiu como acidente aquilo que pertence de outro modo. Este erro é comumente cometido com relação ao gênero das coisas, como, por exemplo, quando se diz que ser cor é acidente do branco, pois ser cor não é acidente do branco mas seu gênero". Como nota David Ross (1987 p. 64-65), o fato de serem os topoi estratagemas para a argumentação dialética (mais tolerante que a argumentação estritamente científica) não significa que Aristóteles esteja assim comprometido com raciocínios incorretos (como o exemplo supra deixa patente). Conforme o próprio Aristóteles [101a25], a utilidade do conhecimento dos tópicos da prática dialética pode ser sumariada como: 1) exercitar, qual numa ginástica mental, a capacidade argumentativa (nesse sentido, os topoi são como movimentos 
dimensões - temática e procedimental — estão presentes.

\section{1) A tópica do eleatismo espinosano segundo Hegel}

Na história de constituição dessa tópica, central é o trabalho de Hegel, pois sintetiza o acervo de críticas elaborado pela tradição anterior, renova-o de modo peculiar e o retransmite para o século XX. Ademais, nas Lições de História de Filosofia, logo após haver feito uma rápida biografia intelectual de Espinosa e um resumo de seu sistema, Hegel explicitamente reenvia o espinosismo ao eleatismo, enunciando o topos $\left(\mathrm{n}^{\mathrm{o}} .1\right)$ a partir do qual se justifica nome aqui proposto à tópica:

"tal é, em seu conjunto, a idéia espinosista; é no fundo o mesmo que o òn [o ente] dos eleatas; Esta idéia espinosista deve ser reconhecida, em geral, como verdadeira, como fundada; a substância absoluta é a verdade, mas não é a verdade inteira",

E, depois dessa referência ao ente parmenídico no capítulo das Lições sobre Espinosa, Hegel arremata o nó com que pretende alinhavar essas duas filosofias, pedindo que se confira, em retrospecto, o capítulo sobre Parmênides, no qual, depois de transcrever parte do poema do mestre eleata, cita, reciprocamente, Espinosa:

"omnis determinatio negatio est é o grande princípio de Espinosa. Segundo Parmênides, qualquer que seja a forma que assume o negativo, ele absolutamente não é",

O trecho do poema de Parmênides, ao qual Hegel faz suceder o comentário acima, é subseqüente ao momento em que a deusa - enunciadora da sabedoria que o poema almeja transmitir - discerne os únicos dois caminhos de investigação nos quais cabe pensar: "um, que é (éstin), tal que não seja não ser (ouk ésti mé einai)", e o outro "que não é (ouk éstin), tal que é forçoso que seja não ser (chréón ésti mé einar)"7. Este último caminho, diz a deusa, é uma trilha totalmente imperscrutável (panapeuthéa atarpon)

argumentativos básicos, "golpes" ou "passos" fundamentais); 2) permitir a discussão com outras pessoas, partindo das premissas delas mesmas; 3) colaborar com a ciência, (3.1) discernindo dificuldades significativas sobre ambas as faces de um problema e (3.2) promovendo uma aproximação ao conhecimento dos primeiros princípios das ciências, uma vez que estes não podem ser, eles próprios, demonstrados cientificamente.

${ }^{5}$ Hegel (2002); Vol III, p 284, inciso meu.

${ }^{6}$ Hegel, Op. Cit. Vol I, p 233.

${ }^{7}$ Procurei manter a literalidade mas pretendendo manter o seguinte sentido: o ente é e não pode não ser, e o não ente não é e é necessário que não seja” 
pois "não conhecerás nem dirás o que não é" (oute gnoiés oute frásais to mé eón) ${ }^{8}$. Hegel interpreta o sentido desse passo dizendo: "o nada se converte em algo a partir do momento em que é pensado ou dito; dizemos algo ou pensamos algo quando queremos pensar e dizer o nada" ${ }^{\text {. }}$ Pensar ou dizer o nada exigiria, pois, sequer perfazer esses atos; nada pensar seria, stricto sensu, tão somente não pensar. E se pensar é pensar algo distinto do nada, será pensar um conteúdo determinado, ou seja, isto ou aquilo. A leitura de Hegel sugere uma compreensão primeiramente predicativa - ainda não existencial — do verbo ésti (é) e do particípio presente ativo eón (ente), usados nesses fragmentos ${ }^{10}$, entendendo que dizer ou pensar "o que é” é dizê-lo ou pensá-lo como sendo algo, isto é, possuindo aquele atributo qualquer (isto ou aquilo) que constitui o conteúdo inseparável do ato de pensar ${ }^{11}$. Assim, apenas em segundo lugar e derivadamente, também não se poderia pensar ou dizer que o não-ente existe e nem mesmo que não existe, simplesmente porque nem sequer haveria algo - o atributo pelo qual o nada deveria ser trazido à mente, se o possuísse - de que se pudesse negar ou afirmar a existência. Não se trata de mera impossibilidade externa de existência, mas sim de uma negação de

\footnotetext{
${ }^{8}$ Fragmento II. Cf. Kirk, Raven \& Schofield Os filósofos pré-socráticos. Lisboa, Fund. Calouste Gulbenkian, 1994; p 255.

${ }^{9}$ Hegel, Op. Cit. Vol I; p 233. Hegel não força excessivamente o texto ao introduzir o termo "nada" onde, no entanto, só comparecem formas verbais como "não é" e "não ser" (ouk éstin, mé einai), pois, como também notam Kirk, Raven \& Schofield (Op. Cit. p 256), "Parmênides prossegue com a referência ao que não é como sendo o nada". Cf. linhas 1-2 do fragmento VI: "pois [o que] é [tem] ser, e não [o que] é nada" (ésti gar einai, médén d'ouk éstin); e linha 10 do fragmento VIII: "e que necessidade o teria levado a surgir mais tarde do que mais cedo, se viesse do nada?" (tí d’ án min kai chréos órsen ústeron éprósten, tồ médenos arxámenon, phun;),

${ }^{10}$ Nenhuma interpretação das formas do verbo ser — conjugada, participial e infinitiva - que comparecem no poema de Parmênides está inteiramente livre de controvérsias. Todavia, considerando o comentário feito por Hegel e tendo no horizonte a correlação que, através do conceito de determinação, ele estabelece também com Espinosa, torna-se necessária uma leitura primeiramente predicativa das formas verbais em jogo. Ademais, independentemente da leitura hegeliana, é possível considerar que "o emprego que Parmênides faz de éstin é simultaneamente existencial e predicativo" (Kirk, Raven \& Schofield Op. Cit. p. 256). Em que sentido isso possa se dar, tento mostrar logo a seguir, no corpo do texto. Noto, porém, agora num registro mais filológico do que lógico, que a forma participial já indica um "o que é" e, portanto, a presença de um elemento substantivo que ocupe o papel de "o", como sujeito da ação de ser, inclusive quando essa ação de ser possuir sentido existencial. Um "o" do qual só se avança a precisão de que existe, há de ser, de saída, um algo, que não interessa, no momento, especificar "o que" é, mas que necessariamente possui esse pré-requisito para existir, qual seja, possuir uma "oquedade" (quiditas, dirá a escolástica latina) e constituir um conteúdo qualquer. O particípio, assim, parece valorizar uma leitura primeiramente predicativa. E talvez se possa dizer o mesmo inclusive da própria forma conjugada do verbo ser na terceira pessoa do presente do indicativo ativo, pois que também aí se pressupõe um "ele" para ser. Finalmente, formas infinitivas também podem desempenhar, tanto em grego quanto em latim e em português, funções predicativas, como, por exemplo, na frase "julgo Sócrates ser justo", a qual, embora menos usada em português do que a paráfrase que se vale de uma oração subordinada — "julgo que Sócrates é justo" —, é absolutamente lícita e traduz de modo literal a sintaxe das usuais frases infinitivas latinas e gregas.

${ }^{11}$ Veja-se, por exemplo, Descartes: não podemos conceber a substância senão através de um atributo.
} 
essência: o não-ente é inexistente porque, antes de mais nada, não é essente, e só por isso está definitivamente impossibilitado de ser dito ou pensado. $\mathrm{O}$ ensinamento da deusa poderia ser, então, parafraseado da seguinte maneira: o não-ente não tem predicados — pois, se fosse isto ou aquilo, teria uma essência e realizaria justamente a ação que o enunciado exclui - e, por isso, também não pode ser sujeito de proposições existenciais, no sentido de que não há isto ou aquilo para um $X$ qualquer instanciar ou não ${ }^{12}$.

Assim, motivado "por uma preocupação acerca do que é um conteúdo possível para um pensamento genuíno"13, Parmênides enuncia o exato trecho que Hegel comentará através da referência a Espinosa: "é forçoso dizer e pensar o ente ser, pois ele é ser e o nada não é"14. Mas de onde vem, então, a iniciativa hegeliana de evocar a frase de Espinosa — omnis determinatio negatio est — se a conclusão obtida foi justamente a de que todo objeto de pensamento deve ter um predicado tal que o distinga do nada? Não está dizendo Parmênides justamente que todo predicado, toda característica, toda determinação é determinação do ente e não do nada? E, visto que o nada não possui predicados, então, inversamente, não seria tanto mais real, tanto menos abstrato, aquilo que tivesse tantas mais determinações? Não seria, antes, toda determinação uma afirmação de realidade? Como então evocar, a propósito desse texto de Parmênides, a idéia de que "toda determinação é uma negação"? Ora, citada como concordante com a opinião de que "qualquer que seja a forma que assume o negativo, ele absolutamente não é", tal idéia deve significar que nesse ente, puramente positivo, as determinações que o diferenciassem dissolver-se-iam e perderiam toda efetividade: no ente eleata, assim como - supostamente - na substância espinosana, toda determinação não é, não tem ser, é mera negação. Em termos lógicos, falar em dissolução das determinações é falar que, abarcando tudo em uma unidade, o pensamento de ente não pode conter nenhuma precisão no âmbito daqueles atributos (isto ou aquilo) que fundam a impossibilidade de pensar o nada. Ou, por outras palavras, enquanto pensamento de abrangência infinita, seu conteúdo deve tender a zero. Hegel estaria, assim, trabalhando

\footnotetext{
12 O não-ente não determina um conjunto vazio, uma vez que vazio é o conjunto cuja legítima convocação de elementos não foi atendida por nenhum; já no caso do não-ente, simplesmente não há convocação e a ausência de elementos é, por isso, intrínseca $\mathrm{O}$ não ente não é apenas a ausência de referente ou extensão mas, primariamente, a absoluta ausência de significado ou compreensão, é negação de essência. Por isso se justifica, aliás, a passagem à idéia de nada, referida em nota supra.

${ }^{13}$ Kirk, Raven \& Schofield, Op. Cit. p. 258

14 “chrè tò legein te noeîn t' eòn émmenai ésti gar einai, méden d'ouk éstin". A tradução de Kirk e Raven é: "Forçoso é que o que se pode dizer e pensar seja; pois lhe é dado ser, e não ao que nada é" Cf.: Kirk, Raven \& Schofield, Op. Cit. p. 257.
} 
com o chamado "princípio de especificação", isto é, com a regra da proporção inversa entre a extensão e a compreensão do conceito, regra que encontra aí, no conceito de ente, um de seus casos-limite. Do ente só se poderá, então, dizer algo que nada acrescente ao seu conteúdo, ou seja, isso mesmo, que ele é, bem como um cortejo de outros predicados tautológicos ${ }^{15} \mathrm{e}$, por isso, inofensivos à sua abrangência. Porque fala de tudo, o discurso sobre o ente — a ontologia — nada diz, e o silêncio se impõe na via do ente assim como se impunha na do não-ente. Dizer que o ente é, constitui, nas palavras de Hegel, "concisa determinação", o que significa que a ontologia eleata se resume a isso e que, depois do ensinamento da deusa - "é forçoso dizer e pensar o ente ser" —, nada mais tem efetivamente a acrescentar. Pelo contrário, o que o eleatismo produzirá será ou uma ontologia negativa, já que a determinação pela qual caracteriza o ente, seu objeto formal, é a própria indeterminidade, ou uma anti-ontologia, uma vez que se prestará a colocar em aporia todo aquele que quiser dizer e pensar algo de não meramente tautológico sobre o ente. Espinosa seria, pois, um eleata, na medida em que, havendo afirmado a positividade do ente de maneira completamente unilateral e contraposta à negatividade do não-ente, acabaria por revertê-la nesta última, sem se dar conta disso, como é próprio a uma filosofia do entendimento:

"A substância, tal como é compreendida por Espinosa, imediatamente, sem mediação dialética anterior, é, enquanto a potência universal negativa, algo somente como esse abismo sombrio, informe, que engole para dentro de si todo o conteúdo determinado como sendo originalmente nulo, e que nada produz que tenha em si uma consistência positiva"16

Como diz Hegel, em A Ciência da Lógica, na nota 1 do célebre primeiro capítulo da doutrina do ser, Espinosa encontra-se junto dos eleatas por partilhar do chamado "sistema da identidade", para o qual o ser, não passando de uma identidade abstrata do mesmo consigo mesmo $(\mathrm{A}=\mathrm{A})$, se reverte, à revelia, no nada:

"Ser, puro ser - sem qualquer outra determinação. Em sua imediatidade indeterminada, é igual só a si mesmo, e tampouco é desigual frente a outro; não tem nenhuma diferença, nem em seu interior nem no exterior. Se alguma determinação ou conteúdo se diferenciasse nele ou o pusesse como diferente de outro, não seria

\footnotetext{
${ }^{15}$ Ingênito (agenehton), imperecível (anwlethron), atual (nun estin), sui generis (mounogenes), único (hen), consistente e contínuo (sunechés), não é divisível (oude diaireton estin), perfeito ou completo (teleion).

${ }^{16}$ Hegel, G.W.F. (1995) pp 281-2.
} 
conservado em sua pureza. É a pura indeterminação e o puro vazio. Nada há nele que se possa intuir, se se pode aqui falar de intuir; ou então ele é esse puro e vazio intuir em si mesmo. Tampouco há algo em que se possa pensar, ou então este é igualmente um pensar vazio. $\mathrm{O}$ ser, o imediato indeterminado, é na realidade o nada, nem mais nem menos do que o nada" 17

O sentido dessas asserções se desdobra e se completa em uma plêiade de outros textos, distribuídos por quase toda a obra de Hegel, coordenando os demais topoi que se subordinam à acusação de eleatismo. Desejo, então, apresentar alguns desses textos, não só para precisar melhor o conteúdo e os procedimentos discursivos da referida tópica mas, sobretudo, para poder encaminhar a caracterização de meus interesses no estudo da teoria espinosana da definição. Tome-se, assim, primeiramente, o que mais acima chamei renovação hegeliana das críticas tradicionais a Espinosa, ou seja, a recolocação dessas críticas - que antes concluíam ser a obra espinosana monstruosa, abominável, pestilenta, infernal, etc. - agora sob a forma de um peculiar elogio:

"ser espinosista é o ponto de partida essencial de toda filosofia. Pois, (...) quando se começa a filosofar, a alma tem que iniciar banhando-se no éter da substância una, no qual naufraga tudo o que vinha sendo tido como verdade. Esta negação de todo particular a que necessariamente tem que chegar todo filósofo é a liberação do espírito"18.

Ora, esse elogio - o ponto de vista espinosano identificado ao começo que instaura o filosofar - é a parcial contra-face indissociável de um novo topos: o filosofar espinosano é incipiente ( $\mathrm{n}^{\mathrm{o}}$. 2). E isso em dois sentidos. Primeiramente porque, da perspectiva hegeliana, como já transpareceu em citação anterior, "a substância absoluta é a verdade, mas não é a verdade inteira" ${ }^{19}$, ou seja, um ponto de partida legítimo - e até necessário - mas que ainda precisaria de algum aprimoramento. Entretanto, num segundo sentido, mais refinado e mais comprometedor, da expressão incipiente, o espinosismo seria, além do mais, uma filosofia essencialmente constituída pela própria categoria de começo. Quer dizer, ele seria incipiente não só porque seus conceitos fundamentais - nomeadamente, os de substância e causa sui - precisam ser aprimorados num ou noutro aspecto restrito, mas sobretudo porque o aprimoramento

${ }^{17}$ Hegel, G.W.F. Ciencia de la lógica. Trad. Augusta e Rodolfo Mondolfo. Buenos Aires, Solar/Hachette, 1968; p 77.

${ }^{18}$ Hegel, Op. Cit. Vol III; p. 285; itálicos meus.

${ }^{19}$ Hegel, Op. Cit. Vol III; p. 
decisivo consistiria precisamente numa retomada crítica de qualquer primeiro conceito fundamental que houvesse sido posicionado, de uma vez por todas, à maneira de um alicerce, como se não houvesse gênese dele próprio ou desse seu posicionamento. São esclarecedoras quanto à significação do topos da incipiência espinosana, as seguintes palavras de Pierre Macherey:

"não é surpreendente que Hegel esteja ele próprio engajado na empreitada de uma crítica do espinosismo: uma das idéias cruciais de seu próprio sistema é, com efeito, que o saber absoluto não começa, ou mais ainda, que ele não pode começar absolutamente; sua infinitude se descobre justamente nessa impossibilidade de um começo verdadeiro que seja também um verdadeiro começo" ${ }^{\text {20 }}$.

É isso que se vê nas censuras hegelianas dirigidas justamente ao uso de definições como bases para o encaminhamento dedutivo:

"toda a filosofia de Espinosa já está contida nessas definições, as quais são, no entanto, definições de caráter completamente formal; e nisto reside o grande defeito de Espinosa, em que sempre parte de definições. Nas matemáticas, esse procedimento é válido, pois partem de pressupostos tais como o ponto, a linha, etc.; mas em filosofia não, pois aqui deve-se conhecer o conteúdo como verdadeiro em si e para si. Cabe, talvez, assentir à exatidão de uma definição nominal, de tal maneira que a palavra "substância" corresponda à idéia que a definição fornece; mas uma coisa é isso e outra é que o conteúdo seja verdadeiro em si e para si. Este problema, que não tem a menor importância nas proposições geométricas, é precisamente o fundamental nas reflexões filosóficas; mas Espinosa não entende assim. Em vez de limitar-se a explicar esses pensamentos simples nas definições que estabelece, expondo-os como se fossem algo concreto, deveria, em rigor, haver investigado se esse conteúdo é verdadeiro. O que é dado é aparentemente uma explicação de palavras, mas o que importa é o conteúdo que aí se encontra. Todo outro conteúdo se reduz a ele e se prova a partir dele, pois do primeiro conteúdo depende qualquer outro e, tomando aquele como base, dele se deriva necessariamente, 21

${ }^{20}$ Macherey, P (1990) p. 22. Considero bastante precisa a seguinte síntese que Macherey faz do comportamento de Hegel diante de Espinosa. Macherey pergunta: "ignora Hegel que essa aporia do começo, que coloca sua Lógica em movimento, essa impossibilidade de assentar o processo infinito do conhecimento sobre uma verdade primeira que seja seu fundamento ou princípio, é também uma lição essencial do espinosismo, objeção principal que ele próprio opõe a Descartes?”; e logo depois responde: "o que Hegel não vê em Espinosa é essa verdade nova da qual ele próprio reivindica a descoberta e que utiliza para garantir a forma final de sua filosofia e o sucesso de sua realização. Hegel, portanto, ignora em Espinosa aquilo que estava melhor posicionado do que qualquer outro para reconhecer, uma vez que o pensou por si próprio: poderíamos dizer que ele empreende a denegação daquilo que podia haver de hegeliano em Espinosa" - Op. Cit. p. 23.

${ }^{21}$ Hegel, Op. Cit. Vol III; p. 289-90. 
Se a realidade não possui um começo, então é descabida a pretensão de representá-la com um sistema formal dedutivo, que parte de definições iniciais e que prossegue, apenas combinando-as e recombinando-as, sob a legislação de certos axiomas. Assim, por um lado, o topos da incipiência se desdobra no do formalismo espinosano $\left(n^{0} .3\right)$, defeito que Hegel explicitamente relaciona à transposição do modelo do conhecimento matemático para o filosófico. Se toda a filosofia de Espinosa já está contida nas definições iniciais, então, como na matemática, o conhecimento produzido ao final do percurso terá a forma de uma igualdade. Nesta medida, Espinosa é dito reincidir em erro idêntico ao da antiga lógica aristotélica, pois ainda permaneceria no campo meramente formal da validade, isto é, da verdade como pura coerência novamente: $\mathrm{A}=\mathrm{A}$-, sem alcançar o campo da verdade "propriamente filosófica", capaz de espelhar não só o mesmo mas também o outro, isto é, capaz de correspondência. A demonstração geométrica, sendo indiferente ao conteúdo do conhecimento, seria, pois, uma forma abstrata e uma regulamentação externa, que ao invés de reunir-se à concretude, submetê-la-ia a si. Espinosa, assim, postularia certos elementos iniciais como se fossem indemonstráveis sem que, no entanto, eles o fossem de direito. $\mathrm{O}$ exemplo escolhido por Hegel é a definição de atributo, que parafraseia da seguinte maneira: "O atributo é o que o entendimento pensa de Deus". Ora, indaga Hegel, como pôde aparecer, fora de Deus, o entendimento capaz de aplicar à substância absoluta os dois atributos, pensamento e extensão? Assim, por outro lado, o topos da incipiência também se desdobra no do dogmatismo espinosano $\left(n^{\circ} 4\right)$.

O espinosismo comparece em Hegel como a mais acabada figura das filosofias do começo. É por isso que, mesmo sendo um vivente do século XVII, Espinosa é identificado, nas Lições Sobre a História da Filosofia, com o começo do filosofar (do qual é próprio justamente o filosofar a partir de um começo). Ora, outro desdobramento desse topos é a idéia de que o espinosismo é a manifestação culminante do orientalismo na filosofia moderna $\left(\mathrm{n}^{\mathrm{o}} 5\right)$. Veja-se, por exemplo, o Adendo ao $\$ 151$ da lógica na Encyclopédie ${ }^{22}$, onde Hegel indica em que ponto a filosofia de Espinosa "ficou para trás" quanto ao verdadeiro conceito de Deus. Enquanto judeu, afirma Hegel, era-lhe familiar a "intuição oriental" segundo a qual "todo finito aparece simplesmente como algo que passa, como algo que desvanece", faltando-lhe, portanto, "o princípio ocidental

\footnotetext{
${ }^{22}$ Hegel Op. Cit. p. 280.
} 
da individualidade" e, nessa mesma medida, um Deus que seja, além de "coisa absoluta", uma "pessoa absoluta", tal como concebido pela "consciência religiosa cristã”. As Lições sobre a História da filosofia, por sua vez, reconhecem, em primeiro lugar, um objeto chamado "A Filosofia Oriental", mas o mencionam sintomaticamente na Introdução $o^{23}$, como em uma ante-sala — para explicar como e por que ele se distingue da "verdadeira filosofia", não devendo ser incluído na história desta última. O fato, em todo caso, é que, por isso mesmo, há uma noção de orientalismo filosoficamente operativa no interior do sistema hegeliano, desempenhando um papel da maior relevância ao tomar parte da definição contrapositiva - coisa que me parece aceitável ao menos para o paladar hegeliano - da "verdadeira filosofia". Segundo Hegel, o que se chama de filosofia oriental é "sobretudo o conjunto de representações religiosas e a concepção de mundo dos orientais", na medida em que "influi nos países do Ocidente, (...) nos quais predomina o espírito da subjetividade". Nessa influência marcada por um descompasso estrutural - tais representações "facilmente se confundem com a filosofia", uma vez que, no Oriente, "o substancial já é por si mesmo o fundamental na religião" e Deus é concebido abstratamente, "com o caráter do universal". Há deuses, mas sua individualidade "carece de firmeza e é puramente superficial”. Em suma, nessas religiões, "a atitude fundamental consiste no fato de que só a substância una é, como tal, o verdadeiro, sem que o indivíduo possua ou possa adquirir qualquer valor próprio". Pelo contrário, o indivíduo "só pode adquirir algum valor verdadeiro mediante a identificação com a substância, na qual deixa de existir como sujeito e desaparece no inconsciente". E isso se exprime, de forma sensível, em seu culto, "que é sumir-se na oração, e uma quantidade interminável de cerimônias e ritos religiosos; e de outra parte, a sublimidade do desmesurado, em que tudo se funde e se esfuma". A positividade máxima do infinito converte-se na neutra indeterminação do nada.

Ademais, há o topos do imobilismo $\left(\mathrm{n}^{\mathrm{o}}\right.$ 6), tradicionalmente associado ao eleatismo. À já citada asserção hegeliana de que "a substância absoluta é a verdade, mas não é a verdade inteira" segue-se imediatamente o considerando: "para sê-lo, haveria de concebê-la como algo intrinsecamente ativo". E não faltam outras formulações textuais de Hegel que reafirmam, nesse conjunto de características correlacionadas, a idéia de um imobilismo espinosano, tais como: "Em Espinosa, a substância, e sua unidade

\footnotetext{
${ }^{23}$ Hegel, Lições sobre a História da Filosofia Vol I, p. 111-113.
} 
absoluta, possui a forma de uma unidade imóvel, de uma rigidez na qual ainda não se encontra o conceito da unidade negativa de $s i$, a subjetividade" ${ }^{24}$; ou "Se Espinosa houvesse desenvolvido mais atentamente o que está contido na causa sui, não teria chegado à conclusão, como chegou, de que a substância é o imóvel (das Starre)"25.

No plano teológico, a peculiar renovação hegeliana das críticas tradicionalmente feitas a Espinosa assume sua forma mais explícita: esse monismo e esse imobilismo não se conjugam, como quisera a tradição, com o ateísmo, pois, pergunta Hegel, como chamar de ateu aquele para quem Deus, e somente Deus, é? Não comete aí, ironicamente, um ímpio ato falho o homem que acha mais natural que se incorra no erro de negar a existência de Deus do que a do mundo? Pois é neste último que, segundo Hegel, Espinosa incorre, embora seja mais freqüentemente acusado do primeiro. E o erro em que incorre não equivale, tampouco, ao panteísmo, se por panteísmo se entende uma doutrina que identifica Deus ao o complexo das coisas finitas, posto que estas supostamente não têm, no espinosismo, realidade efetiva. E se for o caso de dizer que Espinosa é panteísta, que se o diga porque Deus é tudo o que há, quando tudo o que há não seja esse "agregado de finitude que se denomina mundo" mas sim, de novo, tautologicamente, o mesmo Deus. No âmbito teológico da tópica, Espinosa, nem ateu nem bem panteísta, seria, antes, como bom eleata, um negador do mundo, um acosmista $\left(n^{0} 7\right)$.

Destarte, o processo que, partindo de Deus, pretende deduzir o mundo, o homem e sua vida afetiva — ou seja, a Ética — é, pois, uma passagem do ser ao nada; ou melhor, porque passar ao nada é simplesmente não passar a coisa alguma, essa filosofia eliminaria em absoluto a passagem, de acordo, aliás, com seu imobilismo característico. E, remetendo esse imobilismo ao topos do espinosismo como uma filosofia do começo, pode-se dizer, ainda usando a análise de Macherey, que aí se caracteriza, em última instância, "um começo que nada começa, onde o absoluto imóvel constitui a denegação de todo processo", estabelecendo a equação "filosofia incipiente = filosofia declinante", no sentido de que o aparente movimento da Ética, da substância à multiplicidade de modos finitos, de Deus à beatitude humana, não passaria de uma progressiva revelação da inexistência de outra de realidade afora Deus. Destarte, segundo a tópica do eleatismo, Espinosa é, agora de um ponto de vista propriamente ético, um asceta $\left(\mathrm{n}^{\circ} 8\right)$ :

\footnotetext{
${ }^{24}$ Hegel, Logic. trad. Labarrière, Aubier t. I, p249. apud Macherey (1990), p. 18.

${ }^{25}$ Macherey Op. Cit. p 21.
} 
"Da mesma forma como, no espinosismo, o modo, enquanto tal, é justamente o não-verdadeiro, como somente a substância é verdadeira, e como tudo deve ser reconduzido a ela, produzindo o engolfamento de todo conteúdo na vacuidade, em uma unidade puramente formal, sem conteúdo, assim também Shiva é de novo o grande todo (...) O fim mais elevado para o homem instalado na esfera do nascer e perecer, da modalidade geralmente falando, é o engolfamento na inconsciência",26.

\section{2) A tópica do eleatismo espinosano antes de Hegel.}

Diversos outros autores, antes de Hegel, contribuíram para a produção deste estado da tópica, depois transmitido - de muitos modos, mas sobretudo através das heranças hegelianas - ao século XX. São inegáveis, por exemplo, as semelhanças temáticas entre o texto de Hegel logo acima citado e a seguinte passagem de Kant:

"O soberano bem é o nada, despejado no abismo da divindade, aí somos engolfados e a personalidade se esvanece. Para saborear um ante-gosto dessa felicidade, os filósofos chineses fecham-se em locais obscuros, se adstringem a ter suas pálpebras fechadas, se aplicam a meditar, a sentir o seu nada. Daí também o panteísmo dos tibetanos e de outros povos orientais, e depois, mais tarde, por uma sublimação metafísica, o espinosismo, duas doutrinas estreitamente afiliadas a um dos mais velhos sistemas, aquele da emanação, segundo o qual todas as almas humanas, após saírem da divindade, terminam por aí retornar, sendo absorvidas. Tudo isso unicamente para que, a qualquer preço, o homem possa enfim fruir desse repouso eterno que constitui, a seus olhos, o fim bem aventurado de todas as coisas, concepção que nada mais é que uma abolição de todo entendimento, um cessar de todo pensamento. ${ }^{27,}$

E como não reconhecer, antes disso, em Leibniz, a presença da tópica do eleatismo, por exemplo, nos parágrafos 8 e 15 do Sobre A Natureza mesma etc., nos quais se diz que o espinosismo reduz as coisas criadas a "por assim dizer, fantasmas evanescentes e fluidos da única substância divina, que é a permanente"28? Entretanto, sobretudo do ponto de vista da dimensão procedimental da tópica, há uma significativa diferença entre o esquema de ataque ao espinosismo usado por Hegel e o que fora empregado antes dele. Ainda que muitas das imagens ligadas ao suposto eleatismo espinosano já estivessem disponíveis desde o século XVII, o tratamento concedido a

${ }^{26}$ Hegel, Logique, I - "Theorie de la mesure”, trad. Doz, P.U.F. p. 22 ; apud Macherey (1990) p. 27. Itálicos meus.

${ }^{27}$ Kant, La Fin de Toutes Choses, trad. Festugière, apud Macherey (1990) p. 40.

${ }^{28}$ Leibniz, G.W. (1982) p 491 e 498. 
elas possuía outra intenção, qual seja, mostrar Espinosa não como um eleata castiço, disposto a levar às últimas conseqüências a doutrina parmenídica do ente, mas sim como um eleata infiel e, nessa medida, inconsistente. Veja-se, como exemplo paradigmático, o caso de Pierre Bayle, pois, como se sabe, é com ele que

"nasce propriamente a tradição interpretativa do espinosismo. São dele idéias, imagens e sugestões que iriam alimentar, durante os séculos vindouros, as sucessivas leituras da obra e, mais freqüentemente, as substituiriam, o verbete sendo mais lido do que Espinosa. Por ser essencialmente um publicista, divulgador e difusor das opiniões de sua época na perspectiva do protestantismo tolerante, Bayle evita deliberadamente opor à filosofia de Espinosa uma outra, como fizeram os críticos que o antecederam. Pretende colocar Espinosa contra si mesmo para que se destrua. Com seu verbete, institui um campo de generalidades no qual ficou esculpida em baixo-relevo a imagem do espinosismo que seria gravada como um selo nos comentários, interpretações e retomadas que a obra espinosana iria suscitar na fieira dos tempos.",29

É verdade que, na tópica elaborada por Bayle — no "campo de generalidades" por ele instituído - Espinosa já é aproximado do eleatismo, como se pode ver no verbete sobre Xenófanes do Dictionnaire Historique et Critique: "ele [Xenófanes] possuía sobre a natureza de Deus uma opinião que não difere muito do espinosismo” ${ }^{\text {" }}$. Na nota (B) do verbete, Bayle também diz que a doutrina de Xenófanes - segundo a qual, Deus veria e ouviria tudo em geral, mas não isso ou aquilo em particular — recende a espinosismo, pois "Espinosa sustentava que Deus, enquanto substância, não é dotado de senão de pensamento em geral". Ademais, mencionando nominalmente Parmênides e "a seita eleata", Bayle diz que, como Xenófanes, também eles acreditavam na unidade de todas as coisas e em sua imobilidade, e acrescenta que esse modo de pensar pode ser considerado como a origem da opinião cética de que "nossos sentidos nos enganam e que não se deve confiar em seus testemunhos”, já que a percepção sensorial ensina a variedade e as transformações das coisas na natureza. Finalmente, Bayle afirma que Aristóteles refutou tais defensores da imutabilidade e censura Arnauld por haver dito que essa refutação pecava por ignoratio elenchi, isto é, por refutar algo diferente do que propunham Parmênides e Melisso; estes últimos, segundo "o autor de l'Art de Penser", apenas teriam pretendido que há um único princípio de

\footnotetext{
${ }^{29}$ Chauí, M. (1999) p 281.

${ }^{30}$ Bayle, P. (1983) p 133.
} 
onde todas as coisas tiraram sua origem, que é Deus ${ }^{31}$. Ao que responde Bayle: isso é conceder mais honra a Parmênides e a Melisso do que eles merecem, pois não são pessoas ortodoxas quanto à origem das criaturas, mas sim "ímpios como Espinosa", já que também não reconheciam "diferença entre o princípio do qual as coisas são compostas e o princípio que as produz".

Assim, por um lado, é correto continuar dizendo que, desde o século XVII, a acusação de eleatismo dirigida a Espinosa não é, de fato, novidade. Entretanto, por outro lado, a diferença da leitura de Bayle relativamente à de Hegel logo se manifesta. Na nota (F) do mesmo artigo sobre Xenófanes, Bayle repete que não se deve defender esse filósofo, mas agora dizendo que:

"o sentimento dele é uma impiedade abominável, é um espinosismo mais perigoso do que aquele que eu refuto no artigo Espinosa; pois a hipótese de Espinosa traz consigo seu antídoto, dada a mutabilidade ou da corruptibilidade contínua que ele atribui à natureza divina, em razão das modalidades"32

Antes de mais nada, é interessante notar o uso que Bayle faz do termo "espinosismo", aplicando-o a pensadores pré-socráticos e — nisto semelhante a Hegel - tratando-o, pois, como uma categoria supra-cronológica. Bayle tem, portanto, consciência de estar cultivando um "campo de generalidades". Mas, — e isso é o mais importante - , no interior da tópica bayleana do espinosismo em geral, o traço precisivo reservado ao espinosismo do próprio Espinosa é justamente a contradição que ele manifesta, e que é seu próprio antídoto. É por isso que seu espinosismo é menos nocivo do que o de Xenófanes, pois a imutabilidade absoluta que a tradição eleata atribui ao ser infinito e eterno é, no entender de Bayle, "um dogma da mais pura teologia" e que pode, portanto, "ser mais sedutor em favor do restante da hipótese". Já Espinosa, ao instalar no seio do absoluto a variedade e as transformações das coisas naturais, espontaneamente choca e horroriza os grandes e os pequenos espíritos. Não é de estranhar que Bayle qualifique a hipótese espinosana através da noção de monstro "la plus monstrueuse hypotèse —, uma vez que ela é "a mais diametralmente oposta às noções mais evidentes de nosso espírito". Pois, se Deus é uma substância única, que

${ }^{31}$ Bayle, P. Op. Cit. p 132. A nota dos editores reenvia ao capítulo 18 da parte III da Logique. Todavia, ao menos em algumas edições desta última, o texto evocado por Bayle encontra-se no capítulo 19: "Das diversas maneira de mal raciocinar, que chamamos sofismas".

${ }^{32}$ Bayle, P. Op. Cit. p 133-134. 
"produz nela mesma, e por uma ação imanente, tudo aquilo que chamamos criaturas", então esse Deus, nada produzindo que não seja sua própria modificação, é ao mesmo tempo "agente e paciente", "causa eficiente e sujeito", etc. No âmbito do pensamento, isso significa que Deus simultaneamente produziria e teria em si, por exemplo, tanto as idéias verdadeiras do sábio que ensina quanto as idéias errôneas do ignorante que aprende, tanto a idéia que afirma que $\mathrm{X}$ é $\mathrm{Y}$ quanto a idéia que, ao mesmo tempo e no mesmo sentido, nega que o mesmo X seja um tal Y. Quanto à extensão, ao considerá-la como atributo divino, Espinosa incluiria a divisibilidade em Deus, pagando com isso o preço de identificá-Lo ao "teatro de todas as sortes de mudanças, ao campo de batalha de causas contrárias, ao sujeito de todas as corrupções e de todas as gerações”, ${ }^{\text {,3 }}$. E o subterfúgio espinosano, que tenta evitar essas consequiências definindo a extensão como algo indivisível, de nada adiantaria, pois, segundo Bayle, com isso novamente desapareceria a possibilidade de separar as coisas contrárias em distintas porções de matéria, recaindo na inerência dos incompatíveis em um mesmo ente. Assim, se a tese espinosana da unidade substancial é um monstro, é porque, de uma forma ou de outra, ela atribui a Deus todas as coisas ao mesmo tempo, inclusive as que são contraditórias entre si, concebendo-O como "uma natureza atualmente mudando, e que passa continuamente por diversos estados, que diferem interna e realmente uns dos outros". E não é demasiado relembrar o bem conhecido topos cunhado por Bayle - no espinosismo, dizer que "os alemães mataram dez mil turcos" é o mesmo que dizer que "Deus modificado em alemães matou Deus modificado em dez mil turcos — porque ele deixa muito claro que, dos muitos lugares comuns que Bayle partilha com Hegel, aqui não cabe a imagem hegeliana do "oceano da indiferença" mas tão somente a do revoltoso mar da contradição, imanentemente agitado pelo movimento, pela guerra e pela morte.

Sob o tratamento que Hegel lhe confere, a filosofia espinosana, na mesma medida em que é valorizada, tem suas tensões internas apagadas, já que é descrita como um eleatismo conseqüente, que concede substancialidade apenas a Deus e, coerentemente, trata as coisas finitas como epifenômenos sem verdadeira realidade. Hegel defende Espinosa da acusação de ateísmo ao preço de homogeneíza-lo, reduzindo toda uma dimensão do sistema espinosano — a da modalidade finita — a literalmente nada, ao invés de enfrentar o desafio de tentar integrá-la. A leitura hegeliana é — para

\footnotetext{
${ }^{33}$ Bayle, P. Op. Cit. p 63.
} 
qualificá-la em seus próprios termos — unilateral, e projeta essa unilateralidade sobre Espinosa. Por isso, se é correto dizer que, desde o século XVII, não há novidade na acusação de eleatismo dirigida a Espinosa, não é correto, porém, supor que os críticos do espinosismo "estão todos dizendo mais ou menos a mesma coisa", pois, como já foi perspicazmente notado,

"as conseqüências últimas que, no plano lógico, desprendem-se da ontologia espinosana são, conforme se considere a interpretação de Bayle ou a de Hegel, exatamente opostas. Bayle aponta que Espinosa, por sustentar o absurdo da existência de uma única substância, acaba com o princípio de não-contradição, a lei do pensamento mais firmemente assentada, o mais certo e incontestável entre os conhecimentos humanos. Hegel, por sua vez, considera que é o respeito clássico de Espinosa, um filósofo do Entendimento, pela nãocontradição o que impede o advento do movimento efetivo",34

Tais formas de recusar o espinosismo constituem, destarte, polos interpretativos antagônicos, e será necessário argumentar contra ambos, defendendo que "as modalidades" nem implicam a contraditoriedade da natureza divina nem se dissolvem em meras negações. Em termos textuais, no interior da obra de Espinosa, uma tal argumentação consistirá em compatibilizar a já citada tese da unidade substancial (proposição 14 de Ethica I) com a tese de que, não obstante, dessa substância una e única seguem-se necessariamente infinitas coisas de infinitos modos, como afirma a proposição 16 da mesma Parte: "Ex necessitate divinae naturae, infinita infinitis modis (hoc est, omnia, quae sub intellectum infinitum cadere possunt) sequi debent ${ }^{35}$. Ora, o fundamento da demonstração da proposição 16 é a teoria da definição ${ }^{36}$. Logo, das muitas articulações

${ }^{34}$ Gainza, M. (2007) p 19. Desejo manifestar aqui minha mais profunda gratidão à autora desse artigo, Mariana de Gainza. Devo a ela a percepção da perfeita inversão lógica entre as posições de Bayle e Hegel e, de minha parte, apenas acrescentei que isso corresponde ao plano das diferenças procedimentais da tópica do eleatismo. Também devo ao uso que Mariana de Gainza faz do livro de Macherey - Hegel ou Spinoza —, a tradução do problema aqui em pauta na pergunta concisa: "Espinosa clássico?" (Gainza, M. Op. Cit. p 36), que me serviu de deixa para cunhar a interrogação que comparece no título da próxima seção: "Espinosa parricida?". Quanto à resposta, porém, tenho a impressão de que nossas posições diferem, pois tendo a acentuar a fidelidade de Espinosa à racionalidade clássica, centrada no princípio de não-contradição (na lei do pai Parmênides), ao passo que a comentadora se empenha em defender uma ruptura espinosana com esse princípio e em pensar o espinosismo como uma dialética materialista avant la lettre. Mas, creio que essa divergência não se deva tanto ao modo de compreender Espinosa, e sim ao modo de compreender a própria racionalidade clássica e seu princípio fundamental.

35 "Da necessidade da natureza divina devem seguir-se infinitas [coisas] de infinitos modos (isto é, todo que pode cair sob um intelecto infinito)"

36 A demonstração se inicia precisamente dizendo: "Essa proposição deve ser manifesta a qualquer um, desde que atenda a isto: de uma definição dada de uma coisa qualquer..." (Haec Propositio unicuique manifesta esse debet, si modò ad hoc attendat, quòd ex datâ cujuscunque rei definitione...) 
possíveis que um intérprete pode buscar entre as proposições 14 e 16 de Ethica I, deve ser possível encontrar algumas que remontam ao De Emendatione e à distinção entre essência e propriedade nele contida ${ }^{37}$. Por outras palavras, a teoria da definição será convocada a responder tanto à acusação hegeliana de eleatismo quanto à acusação bayleana de que, - como os heraclitianos de que fala Aristóteles no livro Gamma da Metafísica - Espinosa colocaria a perder o princípio da não-contradição:

"Se há algo de certo e incontestável nos conhecimentos humanos, é a seguinte proposição 'opposita sunt quae neque de se invicem, neque de eodem tertio secundum idem, ad idem, eodem modo atque tempore vere afirmari possunt (...) os espinosistas arruínam essa idéia e a falseiam de tal forma que não se sabe mais de onde eles poderão obter os caracteres da verdade" 38

\section{3) A tópica do eleatismo antes de Espinosa.}

Como já foi muito bem notado, Bayle "demonstrou onde se encontra o absurdo maior do espinosismo: na somatória de dois erros que formam a monstruosidade

37 E, como a acusação de Bayle ataca a tese da causalidade imanente, também será preciso dizer algumas palavras sobre o papel da teoria da definição relativamente à proposição 15 "Quicquid est, in Deo est, \&o nibil sine Deo esse, neque concipi potest' — e à proposição 18: "Deus est omnium rerum causa immanens, non verò transiens".

${ }^{38}$ Cf. Bayle, P. Op. Cit. p 66. O trecho citado por Bayle em Latim se traduz da seguinte maneira: "são opostos aqueles [termos] que não podem ser verdadeiramente afirmados nem um do outro nem de um terceiro, segundo a mesma [relação], para o mesmo [aquele que afirma], do mesmo modo e ao mesmo tempo". Confesso que tenho alguma dificuldade para diferenciar as cláusulas "secundum idem" e "eodem modo", pois ambas parecem indicar a cláusula aristotélica kata to autò, traduzida por Guilherme de Moerbecke* apenas como "secundum idem". Bayle, a partir da consideração de que Espinosa desrespeita o princípio de não contradição (PNC), chega à mesma conclusão que Aristóteles em Metafísica, IV (Gamma), 4, [1005b 35 ss]. Bayle diz: "Não se pode esperar nada de uma disputa com eles [sc. os espinosistas], pois, se eles são capazes de negar isso, negarão também toda outra razão que se lhes queira alegar". Aristóteles, por sua vez, apresenta uma demonstração refutativa contra os negadores do PNC. O cerne da refutação consiste em colocar o princípio como condição necessária da significação em geral. Isso se faz mediante a tese de que "significar é significar algo uno" (semainei hén). Assim, não é necessário que os adversários do PNC — textualmente relacionados por Aristóteles aos heraclitianos — digam que algo é ou que algo não é, bastando apenas que digam algo para que já pressuponham, no ato mesmo de significar isso e não aquilo, o princípio mesmo que negam. $\mathrm{O}$ argumento aristotélico é bastante sofisticado e eu retornarei a ele logo mais. O que importa aqui é mostrar que a conseqüência geral a que chega Aristóteles é a mesma a que chega Bayle: "seria ridículo buscar argumentação contra quem não sustenta nenhum argumento, na exata medida em que não sustenta. Pois, alguém desse tipo, enquanto é desse tipo, é já semelhante a uma planta"; tradução de Angioni, L. (2006) p 173

* A tradução da Metafísica para o Latim feita por Guilherme de Moerbeke, entre 1262 e 1272, foi a que Tomás de Aquino, amigo e confrade do tradutor, utilizou em seus comentários. Infelizmente não tive oportunidade de verificar a origem dos textos de Aristóteles presentes na biblioteca de Espinosa. Sei apenas, por via de Vulliaud, P (1934), que Espinosa possuía uma obra referida como “Aristote Ed. Lat. Bàle, 1548”. Espero poder, em pesquisa no exterior, durante o pós-doutorado, ter acesso a esta edição Bàle. 
filosófica, isto é, um eleatismo heraclitiano" ${ }^{39}$. Mas, afora a intenção destruidora que prevalece em Bayle, não haverá nessa compreensão algo de verdadeiro? Ora, como mostrarei a seguir, tanto a leitura que Bayle faz de Espinosa quanto a que faz Hegel exploram caminhos teóricos já previamente mapeados pela própria filosofia antiga, no contexto do chamado "parricídio" contra Parmênides (tematizado por Platão num contexto que abrange, principalmente, os diálogos Sofista e Parmênides ${ }^{40}$ ). Como diz o Estrangeiro de Eleia, personagem principal do Sofista, o parricídio, ou melhor, o risco de ser acusado de parricida, provém de que

"[ao tentar definir o sofista] precisamos, necessariamente, para defender-nos, colocar em questão a tese de nosso pai Parmênides e, forçosamente, estabelecer que o não-ente, sob certa relação (katá ti), é, e que o ente, por sua vez, de algum modo (péi), não é",41.

A meu ver, Bayle compreendeu corretamente que Espinosa está entre os suspeitos de parricídio, mas - como Hegel parece haver melhor percebido - situandose aí de forma a demonstrar, ao mesmo tempo, profunda afinidade com a lei paterna. Para uma caracterização desse suposto parricídio - caracterização que ao mesmo tempo evidencie suas ligações com as críticas hegeliana e bayleana a Espinosa convém começar por uma breve incursão no diálogo platônico Parmênides.

\subsection{1) Os paradoxos do Um no Parmênides de Platão}

Na primeira parte desse diálogo, depois de breve intróito, Platão apresenta um debate entre Sócrates e Zenão de Eleia, acerca justamente da estratégia argumentativa de um escrito deste último, lido pelo próprio nessa sua visita a Atenas — provavelmente fictícia - em companhia de Parmênides. O debate, versando acerca das relações entre os procedimentos discursivos de Parmênides em seu poema e os de Zenão em seus escritos, articula ambos em uma única e concisa passagem (127e1 a 128d7). Nela, Sócrates, depois que Zenão lhe atende o pedido de reler a primeira hipótese de seu primeiro argumento ${ }^{42}$, diz o seguinte:

${ }^{39}$ Chauí, M. Nervura do Real, p. 313.

${ }^{40}$ Não pretendo empreender uma exegese direta desses dois diálogos; na verdade, valho-me basicamente de cinco comentadores: Francis Wolff (1996), Luíz Henrique dos Santos (1996), David Ross (1953); Colli, G (2006), e F. Cornford ('). Esses trabalhos me servem como sínteses que enfocam de maneira bastante ágil os pontos de maior relevância para meus argumentos, no contexto da chamada “questão do Um e do múltiplo", em suas dimensões ontológicas, lógicas e físicas.

${ }^{41}$ 241d. Transcrevo aqui a tradução utilizada por F. Wolff no artigo citado na nota supra, p. 198.

${ }^{42} \mathrm{O}$ argumento lido por Zenão não é revelado por Platão; sabemos apenas os elementos que a 
"Sócrates - Ó Zenão, o que queres dizer com isso? Que se múltiplos são os entes (ei pollá esti tà ónta), eles devem ser iguais (bómoia) e desiguais (anómoia), o que é impossível (adynaton); pois nem desiguais podem ser iguais (anómoia hómoia) nem iguais, desiguais (bómoia anómoia). Não dizes isso?

Zenão - Isso mesmo.

Sócrates - Então, se é impossível que desiguais sejam iguais e que iguais sejam desiguais, é impossível ao múltiplo ser (adynaton dé kaì pollà einai), pois, se o múltiplo fosse, padeceria de impossibilidades (paschoi àn tà adynata). Acaso o interesse dos teus argumentos não é senão defender, contra todos os demais, que o múltiplo não é (ou pollà esti)? (...)

Sócrates [a Parmênides] - (...) ele [sc. Zenão] escreveu de certo modo o mesmo que tu; revertendo a direção (tropon metaballwn), tenta nos enganar, como se dissesse algo diferente. (...) Então, quando um diz que o Um é, e o outro, que o múltiplo não é, cada qual parece falar como se nada dissesse de comum com o outro, quando, no entanto, ambos dizem a mesma coisa (...)

Zenão - Sim, Sócrates, mas tu não percebeste tudo acerca da verdade de meu escrito. (...) Antes de mais nada, não percebeste que, de modo algum, ele tem tais pretensões, como se houvesse sido redigido, conforme dizes, com o propósito de resguardar-se perante os homens qual uma obra preciosa. O que dizes é, por um lado, algo de acidental, muito embora, por outro, seja verdade que esses escritos são para o auxílio (boétheia) do argumento de Parmênides contra aqueles que tentam ridicularizá-lo (kwmwdein) como se, de ser o Um, decorressem muitas e risíveis (geloia) conseqüências contrárias ao argumento. $\mathrm{O}$ escrito contradiz (antilegei), assim, os que afirmam o múltiplo, e lhes devolve a mesma coisa (antapodídwsi tautà) e tanto mais, querendo deixar claro que, se alguém a segue passo a passo, a hipótese deles, de que o múltiplo é, sofre de conseqüências ainda mais risíveis (geloiótera) do que a de que o Um é."

Como ressalta o Zenão platônico, embora ele próprio não pretenda qualquer originalidade relativamente ao conteúdo da doutrina do mestre, seu escrito possui, não obstante, um procedimento discursivo distinto, principalmente em função de suas intenções refutativas. A mudança de direção (tropon metaballwn) percebida por Sócrates

pergunta mesma de Sócrates disponibiliza.

43

Platão, Parmênides 127e1 a 128d7. A "tradução" é minha, sem qualquer pretensão de originalidade ou excelência filológica e justifica-se apenas como um esforço de reconstrução de meu próprio entendimento das diversas fontes consultadas a propósito da passagem em questão: a edição bilíngüe da Loeb com a tradução de H. N. Fowler (London, Loeb Classical Library, 1996); Leon Robin (Paris, Plêiade, 1964); M. L. Gill \& P. Ryan (Indianápolis, Hackett, 1997); C.A. Nunes (Universidade Federal do Pará, 1974); e a tradução de Pasquinelli para o Italiano — vertida para o espanhol! apresentada em conjunto com a propriamente espanhola de Ma. I Santa Cruz no já citado livro de Colli, p 41-2 e 50-1. 
retira o ensinamento da forma afirmativa original (o Um é), o transpõe para a forma antitética derivada (o múltiplo não é) e procede, a partir daí, por redução ao absurdo. A reconstrução que Sócrates faz do argumento de Zenão (127e 1) é uma perfeita aplicação da regra de inferência conhecida como modus tollens, pela qual nega-se o antecedente de uma proposição condicional através da negação de seu conseqüente necessário:

se $p$ (múltiplos são os entes),

então $q$ (eles devem ser iguais e desiguais);

ora, não q (isso é impossível: adynaton);

logo, não $p$ (o múltiplo não é).

O determinante de toda redução ao absurdo é, evidentemente, o absurdo, no caso, a co-presença simultânea de predicados contrários (anómoia hómoia) ${ }^{44}$, ou seja, a desobediência ao princípio de não contradição.

Mas, se a hipótese do múltiplo implica contradição, é preciso saber que também é possível acusar de contraditória a hipótese do Um. Zenão, de fato, já o sugeria. Como observa Colli, a personagem Zenão implicitamente admite que a tese de Parmênides é atacável de um ponto de vista racional, e sua ajuda (boétheia) não chega a estabelecer qual seja a doutrina verdadeira, mostrando apenas que os adversários são mais criticáveis:

“Um elemento do maior interesse: ‘...de sua hipótese da

44 A narrativa platônica fala somente do primeiro argumento da primeira hipótese, mas, a acreditar no comentário antigo de Proclo (in Plat. Parm. 29A15 DK, apud Colli, G. Op. Cit. p 164.), o escrito de Zenão estava organizado em quarenta argumentos (logoi). Assim, é lícito considerar, com Colli, que o par de predicados contrários, igual/desigual, era apenas um dos muitos a serviço da destinação geral do livro, qual seja, negar a multiplicidade, havendo, pois, outros pares, tais como finito/infinito, móvel/imóvel, etc. Cada argumento assumiria a hipótese da multiplicidade e a reduziria ao absurdo segundo esses diversos pares, partindo de enunciados tais como: "se há múltiplos entes, são iguais ou desiguais?”, “... finitos ou infinitos?”, “... móveis ou imóveis?”. Ora, esse enunciado é exatamente o que os Tópicos de Aristóteles chamarão de probléma, ou seja, uma proposição que explicita a sua dualidade interna: Segundo Tópicos I, 4 101b 11, a diferença entre um problema e uma proposição é uma diferença na construção da frase. Aristóteles insiste que problemas e proposições são iguais em número, pois de cada proposição se pode fazer um problema se for mudada a estrutura da frase. Um exemplo de problema é o seguinte: "é 'animal que caminha com dois pés' a definição do homem ou não é?". Outros exemplos são: "é preferível o honroso ou o vantajoso?" ou "é mais agradável a vida virtuosa ou a vida dos prazeres?". Nestes últimos casos, a questão é: "a qual dos dois sucede que o predicado em apreço se aplique mais estreitamente?". Um problema explicita, pois, uma dúvida com sua possibilidades de resposta bem demarcadas, contribuindo para a escolha de uma em detrimento da outra. Destarte, o escrito completo de Zenão entabularia uma tópica, com quarenta problemas dialéticos que não seriam propriamente respondidos por uma das possibilidades explicitadas mas, antes, implodidos por uma antinomia, com ambas as partes afirmando-se em igualdade de direito. 
existência dos múltiplos seguem-se conseqüências ainda mais ridículas que as da tese do Um'

Ora, o diálogo de Platão prossegue no sentido de demonstrar que, se o Um existe, a ele devem assinalar-se todos os atributos contraditórios. Este é o elemento enigmático do Parmênides de Platão: cabe perguntar se, destruída a hipótese de que os múltiplos existem, e destruída a hipótese de que o Um existe, não nos encaminhamos a um ceticismo absoluto" 45

O escrito de Zenão não demonstra a doutrina eleata, e — sob pena de petição de princípio - nem poderia fazê-lo, já que a base de seu argumento é o princípio de não contradição, isto é, a própria lei parmenídica fundamental, de sorte que, se a intenção de Zenão fosse demonstrar o eleatismo, o estaria fazendo ao pressupô-lo. Zenão simplesmente contradiz os que atacam o Um, devolvendo-lhes a mesma coisa e colocando ambas as posições em pé de igualdade quanto ao fato de implicarem consequiências contraditórias, a diferença residindo apenas no fato de que — por razões que o diálogo não explica - Zenão considera que as consequiências do múltiplo são mais risíveis (geloiotera) do que as do Um. No mesmo registro, o que se apresenta na segunda parte do diálogo, protagonizada desta vez pela personagem Parmênides, é um exaustivo conjunto combinatório de hipóteses quanto à afirmação ou negação do Um, que chegam, todas, a resultados paradoxais. A matriz dessa combinatória pode ser organizada na seguinte tabela ${ }^{46}$ :

${ }_{46}^{45}$ Colli, Op. Cit. p 54.

${ }^{46}$ Sigo aqui o resumo feito por Ross, $O p$. Cit. p 93-94. Em tempo: Ross deixa muito claro que não é possível solucionar esse enigma do Parmênides através de qualquer tentativa de valorizar uma conseqüência ou um grupo de consequiências em detrimento de outras, insistindo, pois, no caráter paradoxal que decorre da afirmação conjunta de todas as consequiências (Cf. p 94-99). 


\begin{tabular}{|c|c|c|}
\hline$\Downarrow$ Hipót. \Implic. $\Rightarrow$ & Implicações p/ o Um & Implicações p/ os "outros" \\
\hline Se o Um é & $\begin{array}{l}\text { Duas implicações opostas: } \\
\text { (1)= ele não admite nenhum } \\
\text { membro dos muitos pares de } \\
\text { predicados opostos: não } \\
\text { existe, não pode ser nomeado, } \\
\text { não se pode dizer algo dele, } \\
\text { não pode ser conhecido, } \\
\text { percebido ou julgado. } \\
\text { (2) = ele admite ambos os } \\
\text { membros de muitos pares de } \\
\text { predicados opostos, existe, } \\
\text { pode ser nomeado e se pode } \\
\text { dizer algo dele, pode ser } \\
\text { conhecido, percebido e } \\
\text { julgado. }\end{array}$ & $\begin{array}{l}\text { Duas implicações opostas: } \\
\text { (3)= eles são semelhantes e } \\
\text { disseelhantes uns aos outros, } \\
\text { iguais e desiguais uns aos } \\
\text { outros, admitindo, pois, } \\
\text { ambos os membros de muitos } \\
\text { pares de predicados opostos } \\
\text { (4) = eles não são } \\
\text { semelhantes nem } \\
\text { disseelhantes uns aos outros, } \\
\text { nem iguais nem desiguais uns } \\
\text { aos outros, não admitindo, } \\
\text { pois, nenhum membro de } \\
\text { muitos pares de predicados } \\
\text { opostos }\end{array}$ \\
\hline Se o Um não é & $\begin{array}{l}\text { Duas implicações opostas: } \\
(5)=\text { ele admite cada membro } \\
\text { de muitos pares de predicados } \\
\text { opostos. } \\
(6)=\text { ele não admite nenhum } \\
\text { membro dos mesmos pares de } \\
\text { predicados opostos. }\end{array}$ & $\begin{array}{l}\text { Duas implicações opostas: } \\
(7)=\text { eles admitem cada } \\
\text { membro de muitos pares de } \\
\text { predicados opostos. } \\
(8)=\text { eles não admitem } \\
\text { nenhum membro dos mesmos } \\
\text { pares de predicados opostos }\end{array}$ \\
\hline
\end{tabular}

E, depois de apresentadas essas oito combinações, o resultado a que se chega na última frase do diálogo - parece bastante frustrante, uma vez que consiste em uma trivialização generalizada:

"quer o Um seja, quer não seja (bén eit'éstin eite mé éstin), ele próprio assim como os outros (autó te kai talla), tanto relativamente a si mesmo quanto relativamente aos outros (kai pros autà, kai pros alélla), todos e de todas as maneiras (pánta pántós) são e não são (estí te kaì ouk ésti), aparecem e não aparecem (phainetai te kai ou phaínetai)"

Faz sentido, portanto, falar de um "caráter enigmático desse texto de Platão". Todavia, essa impressão parece derivar da esperança de que o eleatismo devesse apresentar uma ontologia positiva, um discurso sobre o ente e não, como cheguei a

$47 \quad$ Platão, Parmênides 166c 3 
sugerir mais acima, uma ontologia negativa ou uma anti-ontologia. Assim, o enigma me parece solucionável se o texto platônico puder ser considerado como uma engenhosa transformação desse eleatismo corrosivo em um mapeamento crítico dos desafios que uma ontologia positiva deveria enfrentar. Portanto, a sugestão de que a personagem Parmênides estaria destruindo todas as hipóteses - inclusive a do Um - e, assim, abrindo o campo para um pensamento sofístico de jaez relativista ou cético ${ }^{48}$, não me parece ser nem a única nem a mais frutífera via interpretativa. O eleatismo descrito por Platão parece, antes, ter a função de denunciar que, na tentativa de constituir uma ontologia, o pensamento humano possui o singular destino de enredar-se em antinomias e cair em perplexidades, voltando atrás com freqüência, tentando outros caminhos, sem obter unanimidade entre os diversos colaboradores na busca desse saber sobre real em sua totalidade. Destarte, o conhecimento das dificuldades eleatas apresentadas à ontologia seria necessário como preparação para o posterior estabelecimento de um saber positivo, ausente, de fato e de direito, nesse diálogo. Ademais, no enfrentamento dessas aporias, tal preparação também se converte num exame crítico do uso do próprio instrumento filosófico, que, no caso de Platão, é a dialética. Nesta medida, a segunda parte do Parmênides não precisa ter como objetivo estabelecer tal ou qual doutrina positiva, mas tão somente aquele que a própria personagem Parmênides lhe atribui, a saber, um exercício ou ginástica (gimnasthénai) de definir (horizesthai) Idéias ou Formas (eídos), no caso, o Um. Ora, a promoção de uma tal "ginástica" será justamente uma das funções daquilo que, posteriormente, Aristóteles sistematizará através da idéia de tópica: exercitar, qual numa ginástica mental, a capacidade dialética ${ }^{49}$. Portanto, pareceme justificado considerar essas 8 combinações como uma tópica platônica do eleatismo, no horizonte crítico dos desafios para a constituição de uma ontologia positiva depois de Parmênides. Essa "ginástica" destina-se, pois, a preparar o homem que pretende ser filósofo a enfrentar certa classe de aporias, expostas na primeira parte do diálogo, contra

$48 \quad$ "Ceticismo absoluto e nihilismo. Esta hipótese se apoia na proximidade indiscutível entre Zenão e Górgias. Para Górgias, o conhecimento carece de fundamento; e sabemos com segurança Górgias tem um embasamento filosófico eleático. Parece como se a filosofia se encaminhasse a confundir-se com a retórica, quando se recorda que Zenão é o inventor da dialética (...) Nesse deslocamento, Górgias tem um papel determinante" - Colli, Op. Cit. p 55. Colli, evidentemente, não sustenta esta hipótese, mas a indica como uma das possibilidades interpretativas em campo.

$49 \quad$ Cf. Aristóteles, Tópicos 101a25, já referido em nota anterior. Nas palavras de Wolff, o objetivo dessa segunda parte do Parmênides pode ser descrito como: "exercitar-se na defesa de toda posição a fim de se acostumar à argumentação filosófica, como na Academia"; Op. Cit. p 192. Como será visto no PRIMEIRO CAPÍTULO deste ensaio, essa noção de ginástica remonta à medicina hipocrática. Ora, uma vez que o De Emendatione de Espinosa, na condição de medicina mentis, deve ser colocado nessa mesma tradição que remonta à medicina hipocrática, prenuncia-se um vínculo - cuja exploração excede os limites deste ensaio - entre emendatio, dialética e tópica. 
a possibilidade das Idéias ou Formas ${ }^{50}$. Quem deseja defender a existência destas últimas — como é bem o caso dos membros da Academia —, precisa estar preparado para reverter-se em alvo de ataques, precisa conhecer, por exemplo, os Paradoxos do $\mathrm{Um}^{51}$.

Ora, conforme eu disse ao início da presente seção, toda esta incursão pelo Parmênides tem por objetivo mostrar que as diferenças internas à moderna tópica do eleatismo espinosano não são possibilidades inéditas na antiga tópica do eleatismo em geral e, mais precisamente, que as posições de Bayle e de Hegel são instâncias desses que agora podemos chamar de Paradoxos do Um. Afinal, o que dizia Hegel? Que, se

\footnotetext{
Não me interessam, para a presente exposição, os detalhes dessas primeiras aporias contra as Formas, aporias que os alunos da Academia deveriam, naturalmente, conhecer e estar aptos a enfrentar. Basta-me, para efeito de uma compreensão minimamente completa do quadro de discussões em jogo, indicar que tais aporias aproximam-se — com algumas diferenças que David Ross (Plato's theory of ideas p. 87) indica - ao chamado paradoxo do "terceiro homem". O exemplo da 'grandeza' é suficiente para explicitar o espírito dessas aporias: quando muitos objetos (A1, A2, A3...) são considerados grandes, está sendo pressuposto um caráter uniforme que lhes é igualmente comum, donde se conclui que essa grandeza, enquanto tal (kat’ autó), é una. Essa unidade é a Idéia de grandeza (B). Mas, se B é uma realidade separada, então, novamente, pela mesma razão que se reconhece um B que engloba A1, A2, A3, etc., deve-se reconhecer uma Idéia C que englobe [B(A1, A2, A3, etc.)], e assim também uma idéia $\mathrm{D}$ que englobe $\{\mathrm{C}[\mathrm{B}(\mathrm{A} 1, \mathrm{~A} 2, \mathrm{~A} 3$, etc. $)]\}$, ad infinitum. Como observa Ross, esta e outras aporias daí derivadas - e.g. conhecer uma Idéia redundaria em nada conhecer acerca dos singulares deste mundo, que ela abarca [134 c4] — decorrem da colocação da Idéia no mesmo estatuto lógico daquilo de que é Idéia (e.g. no Protágoras, [330 c2 - e2], onde a Justiça é dita justa e a Piedade, pia); nessa situação, "a cura (the cure) é dar-se conta de que a Idéia não é outra coisa (is not another thing) mas um atributo (an attribute)"-Cf. Ross, Op. Cit. p 86-88.

Nessa mesma linha interpretativa, deve-se notar, com David Ross (Op. Cit. 91-92), que a personagem Parmênides, conquanto apresentando aporias contra a teoria das Idéias, não recusa a tese de que as Idéias são necessárias à existência da filosofia. $\mathrm{O}$ que é atacado é especificamente a forma pela qual Sócrates concebe o participar (metalambánein) dos singulares na Idéia. Decorre daí, portanto, que, se a filosofia deve ser possível (ou, como diz Colli, se não se há de cair num ceticismo absoluto), a natureza das Idéias e da participação deve ser reexaminada metódica e rigorosamente. E, para isso, o investigador deve estar previamente exercitado. São, pois, esclarecedoras desse quadro as seguintes palavras com que Parmênides encerra a primeira parte do diálogo e propõe a ginástica profilático-terapêutica que domina a segunda parte (135 b5 - c10): "Parmênides: - Essas dificuldades e muitas mais são inseparáveis das Idéias, caso elas sejam Idéias das coisas e [ao mesmo tempo] dissermos que são em si mesmas. Aquele que escuta tais afirmações fica perplexo e argumenta que as Idéias não existem, e que, mesmo se existissem, não poderiam de modo algum ser conhecidas pelos homens; ele considera que dizer isso é acertado e, como falávamos há pouco, será uma proeza dissuadi-lo (...) Por outro lado, se alguém, com a mente fixa nessas dificuldades e outras semelhantes, nega a existência das Idéias das coisas e não admite uma Idéia definida para cada coisa individual, nada terá, então, a que direcionar seu pensamento (oudè hexei hopé trepsei tén diánoian), uma vez que nega que a Idéia de cada coisa seja sempre uma e a mesma; dessa maneira ele destruirá completamente a capacidade de discutir (diaftherê̂ dunamin dialegesthai), o que, me parece, já percebeste [Sócrates] muito bem. / Sócrates: — Falas a verdade. / Parmênides: — O que, então, farás quanto à filosofia? (tí oûn poiéseis filosofias peri;). Para onde vais virar-te ignorando essas coisas?". As traduções consultadas para esse trecho foram: a do próprio Ross, Op. Cit. p. 90; a edição bilíngüe da Loeb com a tradução de H. N. Fowler (London, Loeb Classical Library, 1996) e C.A. Nunes (Universidade Federal do Pará, 1974). É de notar que a expressão "destruirá completamente a capacidade de discutir" (diaftherề dunamin dialegesthai) é traduzida por Ross como "completely destroy the significance of all discourse", por Fowler como "utterly destroy the power of carring on discussion" e por C.A. Nunes, como "destruiria por completo a própria dialética". Parece-me que, em qualquer caso, o problema consiste em colocar a perder a dimensão do pensamento e da linguagem que corresponde ao discurso argumentativo, o que será solucionado justamente no Sofista.
} 
Espinosa estivesse plenamente certo, então, o ente uno e único, a substância, não admitiria nenhum predicado, e não poderia ser nem $X$ nem não- $X$, de forma que $o$ maximamente positivo reverter-se-ia no nada (como diz a conseqüência 1 do Parmênides ${ }^{52}$. E o que dizia Bayle? Que, diferentemente de Xenófanes, Espinosa concebe a substância como um Um que não é, ou seja, como unidade contraditória porque detentora de ambos os membros de todos os pares de predicados opostos, $\mathrm{X}$ e não-X, (como prevê a consequiência 5 do Parmênides) ${ }^{53}$. Mas, a que vem essa recondução da tópica do eleatismo espinosano às suas matrizes antigas? Não será isto um acréscimo desnecessário de mera erudição histórica? De forma alguma, pois o que proponho é que Hegel e Bayle estão simultaneamente errados porque não percebem com precisão que a solução espinosana para as aporias do Um encontra-se na mesma via que começa com as respostas platônicas a Parmênides e que, depois, avança na direção das respostas aristotélicas, desenvolvidas com a doutrina das categorias. No exame dessa via, pode-se compreender qual a situação de Espinosa frente ao eleatismo e ao princípio de não contradição, isto é, qual sua situação quanto à acusação de parricídio, topos que é um marco dos esforços pela possibilidade da ontologia depois de Parmênides.

\subsection{2) O topos do parricídio e a solução dos paradoxos do Um no Sofista.}

A suspeita de parricídio, como foi dito mais acima, decorre de que se tenha tentado evitar o colapso eleata da ontologia, rompendo, nalguma medida, com a concepção do ente parmenídico e com a correlata versão intransigente do princípio de não-contradição, afirmando, de alguma forma, que o ente não é, que o não-ente é, que o

52 É de notar, no Parmênides, em 160b 2 - ou seja, ao final do exame das quatro conseqüências da primeira hipótese (i.e. se o Um é) —, uma expressão que mostra inegáveis semelhanças com o já citado parágrafo de abertura da Doutrina do Ser, na Ciência da Lógica, de Hegel: "assim, se o Um é (bén ei éstin), o Um é tudo (panta té esti tò hén) e o Um é nada (kai uodè hén esti), tanto em relação a si mesmo (kai pros heautò) quanto em relação aos outros (kai pròs tà álla hósaútós)". Ross, a propósito, menciona inclusive aquela que chama de "interpretação idealista" dos paradoxos do Um. Tal interpretação considera que "os primeiros 4 argumentos são 'a refutação de uma visão abstrata e meramente erística do Um'. O monismo radical seria reduzido ao absurdo ao ser identificado com a negação da possibilidade de predicação". Mas, nota Ross, as conseqüências 2 e 3, assim como 5 e 7 (i.e. todas aquelas em que há atribuição de predicados opostos, tanto ao Um quanto ao múltiplo), incluem, ao contrário, "a true and concrete notion of unity as a significantly differentiated whole" (Op. Cit. p 94). Essa observação é útil para mostrar que uma leitura como a de Hegel, crítica da suposta abstração espinosana, identificaria esta última apenas à conseqüência 1 . Ross, como já foi dito em nota anterior, refuta a interpretação idealista insistindo que o diálogo não dá preferência a nenhuma das 8 possibilidades.

E como o único ente propriamente dito é a Substância, e esta é Deus, Espinosa é ateu, conclui Bayle. Pode-se hesitar e pensar que a posição de Bayle seria a consequiência 2 do Parmênides. Entretanto, isso não pode ser, uma vez que tal conseqüência prossegue com as seguintes qualificações: "existe, pode ser nomeado e se pode dizer algo dele, pode ser conhecido, percebido e julgado". 
Um é múltiplo e que o múltiplo é Um. A compreensão desse ato em defesa da possibilidade de uma ontologia positiva exigirá, agora, uma breve incursão no diálogo platônico Sofista, no qual se passa do registro aporético-crítico do Parmênides para um registro mais propositivo. Ora, como é bem sabido, o objetivo alegado do diálogo é definir o que seja um sofista. A certa altura (234c 1ss), o sofista é dito ser o detentor de uma técnica de apresentar ficções verbais de todas as coisas (deiknúntas eídóla legómena perí pántón), membro, como os pintores, da classe dos imitadores que produzem simulacros de segunda ordem ${ }^{54}$. Produzindo tais ficções ou imagens (eídóla) no âmbito da linguagem, o sofista é capaz de ostentar qualquer conhecimento mesmo sem possuí-lo; é capaz, portanto, de "dizer algo sem, todavia, dizer com verdade" (légein mèn átta, aléthé dè $m e ́$ - 236e 2-3). Entretanto, essa definição do sofista exige supor que é possível pensar e dizer o falso (pseûdos). Ora, pensar e dizer o falso é pensar e dizer "o que não é" "55. Logo, definir o sofista exige uma tomada de posição que vai muito além desse objetivo pontual, levando quem tenta defini-lo a admitir que é possível pensar e dizer "o que não é" e, assim, a conceder que o não-ente tem uma essência, um conteúdo pensável e dizível, supondo, nesta medida, que o não-ente é (bupothêsthai tò mé òn einai - 237a 3$)^{56}$. Nada de falso é possível sem essa condição, diz o Estrangeiro de Eleia - o eleata esclarecido, capaz de afastar-se de Parmênides — que protagoniza o diálogo.

A existência de discursos e pensamentos falsos - mas que podem ser compreendidos e são, portanto, essentes, justamente para poderem ser compreendidos como falsos - seria, então, o ensejo para o questionamento daquele preceito de Parmênides, a partir do qual iniciei todo este percurso pela tópica do eleatismo espinosano $^{57}$, preceito citado e comentado por Hegel logo antes da menção a Espinosa,

54 Sobre a divisão interna à técnica mimética, veja-se Cornford, Op. Cit. p. 183-4: “o carpinteiro que faz uma cama trabalha com referência a uma Forma única, ao modelo que nenhum carpinteiro fez, mas que está fixado na natureza das coisas e foi feito por deus. Esta Forma é real em sentido pleno; a cama do carpinteiro é algo 'semelhante a essa realidade, mas não perfeitamente real'; pertence ao mundo das coisas sensíveis, que são somente imagens do real. O pintor encontra-se mais longe ainda da realidade. Copia não a Forma mas sim o produto do artesão, e não tal como é (...), não produz uma segunda cama, uma réplica da obra do artesão, mas simulacro". Eis, pois, o que pretendi resumir com a expressão "imitação de segunda ordem".

$55 \quad$ Cf. Sofista 240d 10: "Estrangeiro: - Então, dizes que a opinião falsa (tén pseudé dóxan) opina [ou: pensa] não-entes (doxázein tà mé onta;)? / Teeteto: — Necessariamente (anagkêe)".

56 Na continuação do trecho citado na nota supra: "Estrangeiro: E qual dos dois [essa opinião] opina [ou: pensa] (doxázusan): os não entes (tà mé ónta) não serem (mé eînai) ou, de algum modo (pós) os nulamente entes (tà médamós ónta) serem (eînai)? / Teeteto: - Deve, com efeito, [opinar ou pensar] os não entes (tà mé ónta) de algum modo serem (eînai pós), se há alguém que alguma vez pensa falsamente (pseúsetai: Cornford = "comete um erro"; Cruz Costa e Jorge Paleikat = "que o erro seja possível") por menor que seja".

Cf. página deste ensaio. 
no capítulo das Lições de História da filosofia sobre o eleatismo. O que prescrevia a deusa? Que "não conhecerás nem dirás o que não é" (oute gnoiés oute frásais to mé eón) ${ }^{58}$. Como Hegel interpretava isso? Dizendo que, se "o nada se converte em algo a partir do momento em que é pensado ou dito", então, pensar ou dizer o nada seria, stricto sensu, tão somente não perfazer o ato de pensar ou de dizer ${ }^{59}$. Logo, se isso é verdade, mas se também é verdade que existe alguém — o sofista — que realmente perfaz discursos e pensamentos falsos, que diz e pensa o não-ente com algum sentido (um sentido falso), então, esse não-ente, efetivamente dito e pensado, não pode ser o nada. Isso acarreta uma importante reviravolta nas posições que seriam mais naturalmente esperadas frente ao princípio de não-contradição eleata, pois é precisamente tal princípio que fornece guarida ao sofista, protegendo-o de ser definido como executor de um discurso falso: se não é possível dizer ou pensar o que não é (como diz a deusa); e se o falso é o que não é; então, não é possível dizer o falso; e, portanto, tudo que se pensa e diz é verdadeiro ${ }^{60}$. Desse modo, se todo discurso e todo pensamento são verdadeiros, inclusive os contraditórios entre si, então a diferença entre verdade e falsidade está trivializada, e todo discurso e todo pensamento não são propriamente nem verdadeiros nem falsos, pois vale tudo. Logo, ensinando a fazer prevalecer toda opinião, assim como a refutar toda opinião, o sofista proporia, em meio a essa trivialização generalizada, algo do seguinte jaez: 'todo discurso é indiferente quanto ao seu valor de verdade; portanto, pague meu preço, aprenda minha arte e torne-se apto a controlar a diferença que efetivamente se pode esperar produzir nos discursos, a saber, a de serem persuasivos ou não'. Assim, para evitar essa indiferenciação lógica e a conseqüente hegemonia da pura retórica, é necessário - contra o sofista e a bem da distinção entre o verdadeiro e o falso: jamais contra ela! - recusar a exaustiva dualidade eleata entre o ente e o nada.

\footnotetext{
Fragmento II. Cf. Kirk, Raven \& Schofield Os filósofos pré-socráticos. Lisboa, Fund. Calouste Gulbenkian, 1994; p 255.

59 Confira-se a mesma idéia em Sofista 237e 4, onde se faz a diferença entre falar e dizer algo. O Estrangeiro, glosando Parmênides, enuncia a equivalência eleata entre não dizer algo (mé ti legonta) e nada dizer absolutamente (pantápasi médèn légein); e, logo em seguida, diferencia entre falar, ou melhor, vocalizar (phteggesthai: verbo usado também para os sons dos animais), e propriamente dizer (légein), pois, na perspectiva de Parmênides, aquele que profere o não-ente, vocaliza — faz sons, como traduz Cornford - mas não perfaz efetivamente um dizer (os animais fazem sons, vocalizam, têm voz, mas não têm logos)

60 Veja-se Sofista 260 b passando para 260c e ss: "Estrangeiro: - Não mesclando-se (mé mignuménou) [sc. o não-ente] a eles [sc. a todos os outros gêneros, i.e. Ente, Mesmo, Movimento, Repouso) é necessário que tudo seja verdadeiro (anagkaîon aléthé pánt' eînai); mesclando-se, têm lugar [ou: se geram] (gígnetai) a opinião e o discurso falso (dóxa pseúdés kai lógos) (...) Havendo o falso, há o engano (apátê) (...) Havendo engano, necessariamente cabem em toda parte (panta anagké mesta eînai) as imagens (eidólón), as cópias (eikónón) e as aparências (phantasías) (...) Ora, dissemos que o sofista se abrigara em algum lugar dessa região e negara haver o falso"
} 
Eis, então, a causa da suspeita de parricídio: admitir uma via intermediária entre o totalmente ente (tò pantelós ón), que corresponde ao ente eleata, e o nulamente ente (tò médamós ón), que corresponde ao não-ente eleata, isto é, ao nada ${ }^{61}$. Admitir essa via mista ou intermediária é desobedecer à interdição feita na sequiência imediata do trecho do poema de Parmênides comentado por Hegel com a referência a Espinosa, onde a deusa, referindo-se às opiniões dos mortais (dóxas broteías), ordenava:

“...afasta-te da outra via: é nela que erram os mortais desprovidos de saber e com dupla cabeça (dikranoi); com efeito, em seu coração, a hesitação pilota um espírito oscilante; eles se deixam levar, surdos, cegos e tolos, turba acrítica (achrita), que julga (nenómistai) ser (pélein) e não ser (ouk eînai) o mesmo (tautòn) e não o mesmo (kou tautòn)"

O sofista, como um pintor, usa uma técnica de produção de aparências multiplamente variáveis, manipulando e elevando ao máximo a oscilação das opiniões dos mortais e, por isso, como a Hidra, é dito ter não apenas duas mas múltiplas cabeças (polikéfalon):

"Teeteto: - o não-ente periga (kinduneúei) entrelaçar-se (peplếchthai) numa tal cópula (sumplokén), muito absurda (mála átopon), com o ente.

Estrangeiro: - E como não seria absurda? Vê que, nalguma medida, também agora, por causa desse entrecruzamento (epalláxeós), o policéfalo sofista nos força, contra nossa vontade, a homologar [ou: confirmar] (bomologein) que o não-ente, de algum modo (pós), é.",63

61 Veja-se, a propósito dessa terminologia (tò médamós ón, tò pantelós ón) as referências de Cornford a República, em Op. Cit. p 188.

62 Trata-se do mesmo fragmento 6, cujas primeiras linhas, aqui relembradas, foram citadas anteriormente. O texto grego consultado foi, como para toda a doxografia de Parmênides, aquele disponibilizado em Kirk, Raven \& Schofield, Op. Cit (p 257). A tradução, porém, foi a empregada por Wolff no já referido artigo da revista Analytica, muito embora com algumas pequenas modificações — a bem da literalidade — nos exatos pontos em que introduzo os parênteses com as transliterações do grego. Em tempo: como observa Wolff (O. Cit. p 180), não é sem dificuldade que se decide sobre a quantidade de vias discernidas pela deusa: 2 ou 3? Se se decidir por 2, então esta via aqui referida será a do não-ente (o que faz sentido na medida em que a deusa já dissera que a via do não-ente era totalmente imperscrutável). Se se disser que são 3, então trata-se aqui da terceira via, a via mixta, que mistura ente e não-ente (o que também faz sentido, uma vez que, então, a segunda via - dita pela deusa como uma das duas em que cabe pensar - seria a que pensa e diz que o não-ente não é, caracterizando a terceira como a que pensa e diz que o ente não é e que o não-ente é). Seja como for, o que é decisivo é (i) a interdição da deusa a que se pense e diga que o ente e o não-ente são o mesmo e não o mesmo, e (ii) que isso é, nalguma medida, contestado por Platão.

63 Sofista 240c. Novamente, a "tradução" é minha, mediante a consulta não só ao texto grego mas a todas as demais traduções já citadas. 
Esse entrelaçamento - insistentemente marcado no trecho acima ${ }^{64}$ — entre ente e não-ente, cuja admissão o fenômeno sofístico obriga a realizar, é o verdadeiro fio condutor lógico-ontológico do restante do diálogo. É ele que mobiliza uma revisão crítica das doutrinas pré-socráticas, sucessivamente colocadas e recolocadas nas seguintes chaves de oposição: (i) pluralistas ou unitárias (242c - 245e), (ii) materialistas ou idealistas $(246 \mathrm{a}-247 \mathrm{~d})$, (iii) mobilistas ou imobilistas $(247 \mathrm{e}-251 \text { a } 37)^{65}$. Cornford repete várias vezes ${ }^{66}$ que todas estas chaves de oposição estão, na verdade, a serviço da intenção de isolar a filosofia de Parmênides, a fim de evidenciar as limitações que nela Platão encontrava, mas precisamente porque dela Platão também nutria sua própria filosofia. E, de fato, isso parece justificado à luz do topos do parricídio: trata-se de superar Parmênides e não de recair nas alternativas já disponíveis no pensamento arcaico (o que se exprime inclusive em certo desprezo no tratamento dos grupos contrapostos aos eleatas, isto é, dos pluralistas, materialistas e mobilistas ${ }^{67}$ ). Ora, nos passos iniciais (243c 2), intermediários (246a 1) e finais (250d 8ss) desse conjunto textual, evidencia-se que, assim como havia sido o caso com o não-ente, o exame do ente — uno, imaterial e estático — também termina em aporias.

Quanto à (i) unidade, as aporias aparecem por meio das tensões entre as qualificações do ente como Um (henòs) e como todo (bólon), pois que esta última noção implica a de partes e, assim, a de multiplicidade. Quanto à (ii) idealidade, as aporias decorrem de sua ligação com o (iii) imobilismo. Estas segundas aporias atingem tanto os eleatas propriamente ditos quanto os chamados "amigos das Formas (ou Idéias)". Muito se discute sobre quem seriam estes outros idealistas. Felizmente, não é necessário para meus argumentos tomar uma posição a esse respeito, bastando-me indicar, com Cornford, que é plausível pensar que o alvo visado bem poderia corresponder às

\footnotetext{
É interessante notar que o verbo plêké é derivado da mesma raiz indo-européia de onde provém a raiz -plic- latina, que comparece em explico, implico, etc. e que, no contexto espinosano, foi estudada e valorizada por G. Deleuze em seu estudo sobre o problema da expressão em Espinosa. Já o substantivo sumplokén (composto sun + plêkó , e que poderia, portanto, ser vertido para o latim como complicatio) terá seu uso marcado no vocabulário aristotélico para designar a cópula entre sujeito e predicado no interior da predicação (termo essencial para o desenvolvimento posterior de minha argumentação). O substantivo epalláxis significa cruzamento ou trançamento, como, por exemplo, quando alguém cruza ou trança os dedos (o exemplo, muito concreto, é de Aristóteles, e encontra-se no capítulo 6 de Metaphysica, Gamma [1011a 33], quando o Estagirita diz que não se deve dizer que o que parece é, a não ser que se diga que é o que parece a quem parece, quando parece, quanto parece e como parece, "pois, por exemplo, o tato diz 'dois' quando se cruza (epalláxę) os dedos, mas a visão diz 'um'”).

65 Sigo a divisão do texto de Cruz Costa e Jorge Paleikat, aqui referida numerada de maneira um tanto aproximada.

$66 \quad$ Op. Cit. p 199, 201, 210.

67 É devido observar que estes não são exatamente 3 grupos separados mas, antes, 3 formas de de reunir os não-eleatas, que podem, portanto, comparecer em um ou mais grupos.
} 
primeiras e menos elaboradas concepções socrático-platônicas das Formas ou Idéias, exatamente como aquelas submetidas a crítica no Parmênides ${ }^{68}$. Em todo caso, o que parece menos controverso é que a limitação desses "Amigos das Formas" foi haver concebido o ente em termos demasiadamente próximos aos de Parmênides, colocando em separado (chóris) a realidade (ousia) e a gênese (genesis) (Sofista, 248a 6). A principal aporia que daí decorre é que, em função dessa separação, tais Formas tornar-se-iam incognoscíveis: por um lado — como, aliás, já dizia o poema de Parmênides — a realidade imutável deve ser o que é própria e maximamente pensável e dizível; mas, por outro lado, o pensamento mesmo (phronesis) é uma realidade móvel, pois só há mente (nous) se houver vida (zóé); só há ambos se houver alma (psúchê); e esses três supõem movimento (kinésis). Assim, haveria contradição entre a eminente cognoscibilidade do ente imóvel e o imobilismo absoluto igualmente sustentado pelos eleatas e por aqueles dentre os "Amigos das Formas" que não ousam desafiar Parmênides. Sem que se enfrente o pai, “imóveis são os entes (akinétón tón óntón), e nenhuma mente (médeni noûn) sobre coisa alguma (perì médenòs) há (eînai)", diz, em síntese, o Estrangeiro de Eleia (249b 5). Platão termina a exposição dessas aporias salientando que, também no caso inverso, ou seja, se tudo fosse absolutamente móvel, novamente o pensar e o dizer colapsariam, pois, sem o repouso, nada poderia ser o mesmo, da mesma maneira e na mesma relação ${ }^{69}$.

O saldo dessa revisão das filosofias pré-socráticas é que é preciso, portanto, combater todos os que, afirmando ou a imobilidade absoluta ou a mobilidade absoluta, destroem o pensamento (phronesin), a mente (noun) e a ciência (epistémen); é preciso que o filósofo - como as crianças, que querem sempre 'os dois' - admita que o ente é tanto móvel quanto imóvel. Mas, isso ainda não resolve o caso, uma vez que, por conta dessa conclusão mesma, é preciso admitir que, embora movimento e repouso sejam totalmente contrários entre si (enantiótata allélois), ambos igualmente são (bomoiós eînai); donde o ente, presente em ambos, não coincidir nem precisamente com o movimento nem precisamente com o repouso, sendo, pois, um outro (béteron) que, segundo sua própria natureza (katà tén hautồ phúsin), não está nem em movimento nem em repouso. Com efeito, parece que, se o ente é os dois, então ele não é nenhum dos dois e, de novo,

\footnotetext{
Cf. supra nota

Sofista 249c. Uma tradução mais literal seria: “à parte o repouso (chóris stáseós), não se produziria (genesthai) a identidade de relação (lit: nem 'o segundo o mesmo', tò katà tautà) nem de tema (lit: nem 'o acerca do mesmo', perì tò autò) nem de modo ou maneira (lit: nem 'do mesmo modo', hósautós)”.
} 
como na consequência 1 do Parmênides, ele não seria coisa alguma. Trata-se de uma espécie de retomada dos Paradoxos do $\mathrm{Um}^{70}$, mas que, desta vez, são encaminhados a uma solução através de duas noções que já agora se prenunciam: a Forma do Outro (béteron) e o operador katá (presente na supracitada expressão 'segundo (katà) sua própria natureza'), que pode ser colocado em equivalência com os termos latinos secundum, qua e quatenus ${ }^{71}$. É a partir daí que serão apresentadas as respostas de Platão a Parmênides e que se desdobrará a via de continuidade que leva à doutrina aristotélica das categorias. Ao apresentar essa via, a via interdita, creio deixar suficientemente preparada minha tese de que, ao contrário do que disseram tanto Bayle quanto Hegel, é por ela que Espinosa - nem bem eleata, nem bem heraclitiano - caminha (de modo original, é certo, mas com uma originalidade que só se deixa apreender com nitidez perante o pano de fundo das soluções platônico-aristotélicas).

Recapitulemos. Malgrado todas as censuras sobre a índole de embusteiro ganancioso do sofista, ele figurava como a prova viva de que, justamente porque o embuste é possível, a relação lógica entre ente e não-ente não podia ser uma relação de terceiro excluído. Perfazendo o pensamento e o discurso falso, o sofista manifestava um não-ente que não é o nada mas sim algo outro do que é. Agora, depois da revisão platônica da filosofia pré-socrática, o paradoxo do falso - que era o correlato lógico do desafio ontológico do não-ente — dá lugar à sua complementar contra-face, que é o correlato lógico do desafio ontológico do ente ${ }^{72}$ : como dizer que o ente é, por exemplo,

70 Julguei interessante haver constatado, a esse propósito, a recorrência de certas expressões semelhantes no Parmênides e no Sofista. No Parmênides, como já transcrito anteriormente na nota; em 135 b5 - c10, ao falar das dificuldades inseparáveis das Idéias quando estas são pensadas como Idéias das coisas e ao mesmo tempo como sendo em si mesmas, a personagem Parmênides diz: "se alguém, com a mente fixa nessas dificuldades e outras semelhantes, nega a existência das Idéias das coisas e não admite uma Idéia definida para cada coisa individual, nada terá, então, a que direcionar seu pensamento (oudè hexei hopé trepsei tén diánoian) (...) O que, então, farás [Sócrates] quanto à filosofia? (tí oûn poiéseis filosofias peri;). Para onde vais virar-te ignorando essas coisas? (péi trépsei agnoouménón toútón;)". E, no Sofista, em 250c 10, precisamente depois do momento em que se cocnlui que a realidade não se confunde nem precisamente com o movimento nem precisamente com repouso, devendo ser algo outro, o Estrangeiro pergunta: "para onde é forçoso virar o raciocínio (pồ chré diánoian trépein) aquele que quer, pelo raciocínio, estabelecer uma conclusão segura acerca do ente?”

71 Se o ente é os dois, então ele não é, segundo sua própria natureza, ou seja, enquanto ente, nenhum dos dois. Não se trata, portanto, de afirmar que a realidade encontra-se num estado preciso que não é nem de movimento nem de repouso, o que seria absurdo (Cf. Sofista $250 \mathrm{~d} 1 \mathrm{ss}$ ). Trata-se de dizer que o real qua real não inclui nem exclui o movimento ou o repouso: simplismente não é deles que se trata quando se toma o real enquanto real (Cf. Cornford, Op. Cit. p 229). Parece-me oportuno lembrar que, semelhantemente, quando Aristóteles caracteriza a metafísica como ciência que aborda o ente enquanto ente (tò ón é ón) e, portanto, não o aborda enquanto material e móvel (pois isto faz a física), isso não quer dizer que a metafísica seja o estudo de um ente sobrenatural — para além do ente físico — que seria precisamente imaterial e imóvel (como, no entanto, tal ciência foi considerada por leitores tardios, que não foram capazes de compreender "enquanto" enquanto enquanto).

Esta contra-face já pôde ser chamada — com didática simetria relativamente ao 
movimento e repouso, se estes dois, por sua vez, não podem ser a mesma coisa, pois são totalmente contrários entre si? Movimento e repouso não se encontram no cortejo de predicados tautológicos — 'concisas determinações' — que o eleatismo autorizava. No entanto, como a revisão das filosofias arcaicas concluiu, se deve haver filosofia, é preciso dizer que movimento e repouso efetivamente são! Destarte, quantas vezes o ente for móvel e imóvel, isto e aquilo - finalmente, todos os predicados que são, que exprimem uma essência ${ }^{73}$ - tantas vezes ele também será algo que não o ente. Mas, como era o caso com o não-ente dito no discurso falso, também agora - ao ser verdadeiramente predicado do ente algo que não é o mesmo que ele mesmo - , isso só constituiria um problema se a distinção entre ente e não-ente fosse idêntica à distinção entre algo e nada (na qual, inegavelmente, não há terceiro incluído). Os não-entes (e.g. movimento e repouso), que o ente verdadeiramente é, são o que ele não é segundo a própria natureza dele (katà tén hautồ phúsin), ou seja, o que ele não é enquanto ente, mas são o que ele é em outra relação ou sentido. Assim como o pensamento e o discurso falso exigia que o não-ente não fosse o nada, assim também o pensamento e o discurso verdadeiro mas não tautológico sobre o ente - quer dizer, a ontologia positiva - exige que o ente-enquanto-ente não seja tudo, devendo haver o ente-enquanto-outro. Por

\footnotetext{
"paradoxo do discurso falso" - de "paradoxo do discurso verdadeiro". A expressão foi cunhada por Luis Henrique L. dos Santos, e encontra-se em seu artigo "A harmonia essencial", no qual, com inigualável clareza e concisão, a formulação de tais paradoxos é apresentada: "[o paradoxo do verdadeiro decorreria de que] pretendemos dizer o que é uma coisa A e dizemos: 'A é B'. Ora, ou 'A' e 'B' significam a mesma coisa, e o enunciado não diz mais que ' $\mathrm{A}$ é $\mathrm{A}$ '; ou significam coisas diferentes e, nesse caso, o enunciado diz que A é o que A não é. Em outras palavras, ao pretendermos enunciar o que uma coisa é, ou dizemos que ela é o que é, o que não nos ensina nada a respeito dela (...), ou dizemos o que ela não é, e o que dizemos é trivialmente falso. O paradoxo do falso parece mostrar que um discurso é trivialmente verdadeiro ou não é um discurso; o paradoxo do verdadeiro parece mostrar que um discurso é trivialmente falso ou nada pode revelar sobre o que as coisas são" - in A Crise da Razão; Adauto Novaes (Org.). São Paulo, Companhia das Letras, 1996, p 440. A parte subseqüente desta introdução — como, no geral, toda esta tese - deve muito a este artigo e ao seu autor.

73 Cornford salienta que o argumento funcionaria para qualquer predicado (B e não-B), e que movimento e repouso não devem ser tomados como expressões exclusivas de outras entidades do mesmo tipo em questão. Concordo com Cornford a bem da universalidade do argumento platônico. Ademais, uma tópica que parece haver elencado um grande número de predicados dessa sorte já teria sido elaborada pelos 40 argumentos do escrito de Zenão, mencionado no Parmênides (Cf, nota s supra). Entretanto, do ponto de vista histórico, não se pode deixar de notar a realidade do fato de que esses dois predicados particulares foram efetivamente tomados como sendo insubstituíveis para a conexão entre lógica, ontologia e física. Isso é relevante se pensarmos que os modos infinitos imediatos em Espinosa são precisamente as leis do movimento e do repouso. Mediações históricas podem ser encontradas a partir das próprias observações de Cornford, que apontam para a existência em Plotino dessa supervalorização de tais predicados particulares. Mas, além disso, é de notar, a partir de Wolff, que a segunda via ontológica após Parmênides - a dos Atomistas — será precisamente a que se converterá em uma física, tendo como principal tarefa a demonstração da existência do vazio como condição de possibilidade do movimento (Cf. Wolff, F. Op. Cit. pp 202-225). Assim, embora o argumento valha para quaisquer predicados B e não-B, o fato de que Platão tenha usado particularmente Movimento e Repouso não pode ser sub-valorizado quando se procura, como aqui é o caso, reconstruir um pano-de-fundo histórico para responder às acusações hegelianas e bayleanas dirigidas a Espinosa.
} 
outras palavras: quando pensamos e dizemos que o ente (A) é, por exemplo, móvel (B) - A e B não sendo, portanto, precisamente a mesma coisa —, a verdade desse pensamento e desse discurso não implica que A seja o contrário de $\mathrm{A}$, mas sim que, num outro sentido de ser, A também seja um outro que $\mathrm{A}^{74}$. A relação de alteridade (A é B) é, pois, o terceiro incluído entre a pura identidade $(\mathrm{A}=\mathrm{A})$ e a pura contradição $(\mathrm{A}$ $=\neg \mathrm{A})$ :

"Estrangeiro: - Quando dizemos o não-ente (tò mé òn), ao que parece, não dizemos (ouk légomen) algo contrário ao ente (enantion ti tôิ óntos), mas apenas algo outro (all' béteron mónon) (...) Por exemplo, quando falamos não-grande (mé méga), te parecemos designar mais o pequeno (mâllon tò smikeron) do que o igual (é tò iso)? (...) Então, toda vez que se diz que a negação (apophasis) significa (sémaineín) contrário (enantion), não concordaremos, mas admitiremos apenas que o não- (tó $m e ̂$ ) indica algo outro (tón állón) que os nomes a que é prefixado ou que as coisas (tón pragmatón) designadas (epiphtheggómena) pelos nomes posteriores à negação",75

"Não" não é sinônimo de contrariedade, de incompatibilidade, de pura ausência, de nulidade, etc.; "não" também é asserção de alteridade, posição de diferença. Confundir negação com contrariedade, borrando a alternativa da relação de alteridade, é filiar-se à comunidade secretamente partilhada entre sofistas e eleatas e, finalmente, destruir a filosofia, deixando ao discurso a alternativa entre o silêncio eleata e a retórica sofistica.

\subsection{3) Polissemia do ser: a herança platônica na reformulação aristotélica do princípio de não-contradição}

Pensar e dizer o que algo 'é' não exclui pensá-lo e dizê-lo como um outro, tanto quanto pensar e dizer o que algo não-é. "É" e "não-é" se dizem em muitos sentidos, ou pelo menos em dois: é-enquanto-si-mesmo e é-enquanto-outro, bem como não-éenquanto-si-mesmo e não-é-enquanto-outro. E que o ser se diga multiplamente, é uma das principais teses que Aristóteles herda do Sofista de Platão, tese que, quando

${ }^{74} \mathrm{E}$ esse outro que A (ente), que é B, também é, por sua vez, pura e simplesmente si mesmo e, neste sentido, é ente, embora não seja redundante com A. Assim, por exemplo, movimento (B), que é predicado de A, também pode ser, numa segunda ordem de discurso, sujeito de outra predicação, na qual se dirá o que ele é em si e por si mesmo, muito embora ele não seja o que ente (A) é em si e por si mesmo. Na linguagem de Platão: B (movimento) participa do ente; na de Aristóteles: de B se predica o ser (movimento é ente), ainda que B não seja o predicado que diz o que ente $\mathrm{A}$ (ente) é (o ente não é, precisamente, movimento).

${ }^{75}$ Sofista $257 \mathrm{~b} 3-\mathrm{c} 3$ ) 
apresentada nos textos aristotélicos, encontra-se estruturalmente associada à doutrina das categorias, como, por exemplo, na abertura do livro Zeta da Metafísica:

"O ente se diz multiplamente (tò òn legetai pollachós), conforme delimitamos antes nas discussões a respeito do 'de quantos modos'. Pois ente significa (sémainei) o 'quê é' (tò tí esti) ${ }^{76}$ e um 'certo isto' (tode ti), ou então 'o qual' (tò poiòn), 'o quanto' (tò posòn) ou cada um dos demais que assim se predicam (katégorouménón). $\mathrm{E}$ - de tantos modos sendo enunciado o ente - é manifesto que, entre eles, o ente primeiro é 'o que é' (tò tí estin), o qual precisamente significa a essência (sémaínei tén ousian)"

Assim, vertendo para o esquema aristotélico o problema das relações entre, por exemplo, ente e movimento, tal como Platão com ele se batia, deve-se dizer que movimento não é o que ente é na categoria da quididade ou essência, mas sim em alguma das demais categorias; ou seja, 'movimento' não é a definição de ente, muito embora seja verdadeiro pensar e dizer que o movimento é si mesmo. Em curto: quando, com Platão, se diz 'o mesmo', com Aristóteles se considera que "é” está sendo usado na categoria da quididade ( tò ti esti); quando, como queriam os sofistas, se diz que algo é o que ele não-é, Platão explica que o que se diz é 'o outro' e não 'o nada', ao passo que, no esquema de Aristóteles, isso equivale a precisar que o verbo "é" está sendo usado em alguma das demais categorias que não a da quididade. Dizer que "é" significa tanto ser si mesmo quanto ser algo outro, é o que permite que o pensamento e o discurso se situem para além da tautologia mas sempre aquém da estrita contradição.

Francis Wolff insiste nessa continuidade entre o Sofista de Platão e a doutrina aristotélica das categorias, e mostra que estas últimas são, ao mesmo tempo, os diversos

${ }^{76}$ Yebra traduz "a quididade", a partir da tradução latina de Moerbecke (significat enim hoc quid est). Esta tradução (que não foi a utilizada: Cf. nota infra) é útil para o estabelecimento do vocabulário que empregarei no restante deste trabalho. Por "quididade" entendo o nome daquilo que se quer saber de algo quando se lhe dirige a pergunta 'o que é?' (quid est?); a resposta, se adequada, seja ela qual for, será a quididade deste algo, assim como — com menos estranheza para os falantes do português — se pode perfeitamente compreender que a quantidade de algo é aquilo que se quer saber sobre esse algo quando se lhe dirige a pergunta "quanto é?", e a qualidade, o que se quer saber quando se lhe dirige a pergunta "qual é?". De modo muito simples e despretencioso, creio não faltar com a verdade se disser que as categorias são, basicamente, as perguntas que o pensamento pode dirigir a 'o que é', ou seja, ao ente, a partir do puro fato de que ele é: se é, então, 'o que é?', 'qual é?', 'quanto é?', etc. É interessante notar que, para Aristóteles, assim como "quantidade" e "qualidade", "matéria" também conota uma categoria: ela é a resposta visada pela pergunta 'do que é?'. Quando a pergunta' do que é?' é dirigida a uma casa, a resposta será, por exemplo, 'de tijolos', de maneira que a casa será a forma e os tijolos a matéria; mas, quando dirigida ao tijolo, a pergunta 'do que é?' terá por resposta 'de barro', de maneira que, agora, tijolo pasará a ser fomra em relação a barro, ainda que perdure como matéria em relação a casa.

${ }^{77}$ Metafísica, 1028a 10. Aristóteles (2001) p 13. 
sentidos do verbo "ser", tanto quanto, derivadamente, diversos gêneros de $\operatorname{seres}^{78}$ :

"A teoria das categorias (...) salva, portanto, a linguagem e funda a possibilidade da dialética contra a "lógica" dos eleatas. Neste sentido, pelo menos, e apesar do que diz Aristóteles, ela é herdeira da teoria dos "grandes gêneros" do Sofista (...). Se este é o caso, a via "ontológica" que leva às categorias aristotélicas é aquela que foi trilhada pelo Sofista. (...) A esta continuidade na mesma via, objetarse-á todas as oposições freqüentemente assinaladas entre as "categorias" e os "grandes gêneros" (...) Mas esta oposição, inegável, é menos reveladora da via na qual a ontologia entrou após Parmênides do que a oposição bem conhecida entre as "ontologias" de Platão e Aristóteles, uma ontologia da forma (a "forma" ou "idéia" é mais real do que aquilo de que é forma e que participa dela) oposta a uma ontologia dos indivíduos ("isto aqui", ou pelo menos o que se pode dizer disto aqui, é mais real do que a "classe" à qual pertence). (...) há uma tradição respeitável, que remonta pelo menos a Plotino, que põe no mesmo plano as categorias de Aristóteles e os grandes gêneros do Sofista." 79

Cornford parece ser um dos intérpretes que protestariam contra essa aproximação entre os Gêneros Supremos (mégiston génos) de Platão e as categorias de Aristóteles:

“o raciocínio que se desenvolve aqui no Sofista não dá direito de supor que estes Cinco Gêneros ocupem o lugar que logo corresponderá às categorias de Aristóteles, nem que se os chame "categorias" (...) A confusão não se justifica de nenhuma maneira. Nenhum dos Cinco gêneros (Formas, não classes) de Platão é, na opinião de Aristóteles, uma categoria. Tomemos Ser ou Existência. Em vários lugares Aristóteles diz que Ser e Unidade não são categorias

${ }^{78}$ Cf. Wolff $O p$. Cit. p 185, nota 6. É importante reconhecer, em vista das críticas de Cornford que citarei em seguida, o caráter mediato dessa derivação. Como demonstrou detalhadamente o professor Wolff em palestra realizada em Setembro de 2008 na USP, o passo central dessa derivação é que — como já antecipei em nota anterior — também se pode fazer uma predicação essencial em que o predicado acidental figure, desta vez, como sujeito. Assim, por exemplo, quando se diz que o 'homem é branco', 'branco' é um predicado outro que a essência de homem; mas, numa segunda ordem, se pode perguntar: 'o que é branco?', e a resposta será: 'uma cor', diante do que novamente perguntamos: 'o que é uma cor?', e a resposta finalmente será 'uma qualidade'. 'Qualidade' não é um predicado outro que a essência de 'branco': ser 'qualidade' é a sua 'quididade'. Asssim, e somente assim, é que, mesmo quando predicamos 'branco' de 'homem', pode-se dizer que há uma predicação do ente, pois, mediante essa passagem para uma segunda ordem de predicação, predicar branco é predicar do homem um ente que existe ao modo de qualidade e que, como tal, não existe fora da coisa (no caso: homem) branca (que é o ponto de afastamento relativamente a Platão).

79 Wolff, F. Op. Cit. pp 189-190 - itálicos meus. Este artigo de F. Wolff está intensamente presente na parte que se segue da presente INTRODUÇÃo e, de modo geral, na tese ampla deste ensaio, na medida em que proporei uma aproximação estrutural entre essa sorte de solução platônico-aristotélica (os grandes gêneros e as categorias) para o colapso eleata da ontologia e a solução espinosana para o problema do Um e do múltiplo, que livra Espinosa das críticas de Bayle e Hegel. 
precisamente porque podem ser predicados de todas as coisas; não entram em nenhuma das dez 'casinhas de pombos'. O mesmo vale para a Mesmidade e a Alteridade. Como adverte Platão, pode-se dizer que qualquer coisa é a mesma que si mesma e outra que toda outra coisa. Por essa mesma razão, Aristóteles nega que sejam categorias. Que Movimento e Repouso sejam categorias, é algo que não poderia ocorrer a Aristóteles, nem tampouco os críticos modernos podem explicar que Movimento e Repouso sejam summa genera, seja de entidades ou de predicados. O resultado é que Platão nunca usa a palavra e Aristóteles, que a usa, e a considera inaplicável a qualquer dos cinco gêneros"

Aqui, portanto, fico com Wolff e me afasto de Cornford. E para justificar-me retomo, ao meu modo, algumas indicações de Wolff, sobretudo no sentido de não cuidar tanto da presença ou ausência da palavra "categoria" em Platão nem da discrepância entre este ou aquele gênero platônico e esta ou aquela categoria aristotélica, concentrando-me, isto sim, na função argumentativa que as noções de gênero e de categoria desempenham nos seus respectivos contextos de uso. Assim considerados, penso tornar-se evidente que as duas doutrinas vêm responder ao mesmo desafio eleata, através da discriminação, em ambos os casos, de uma multiplicidade de sentidos do "é" e do "não-é" (que é tudo quanto me basta para traçar o pano de fundo para minhas posteriores colocações sobre Espinosa). Ora, antes de mais nada, é preciso considerar que as categorias de Aristóteles não são imediatamente classes de predicados ou classes de seres ("casinhas de pombos"!) $)^{81}$, mas modos de uso das noções de "é” e "não-é": são maneiras de afirmar e negar que devem ser distinguidas, a bem da eliminação da equivocidade do verbo ser, ou seja, a fim de que, discriminados os múltiplos sentidos de ser, sejam evitadas confusões de efeito sofístico. Em seguida, deve-se notar que o número de dez categorias - dez usos da noção de ser - é contingente, e que Aristóteles, além de variar a enumeração, chega, inclusive, a empregar expressões tais como 'e outros desta sorte', indicando que o conjunto é, de direito, aberto. Mas, o mais importante é que a distinção lógico-ontológica relevante para Aristóteles é precisamente aquela em se discrimina um uso de "é" que exige um predicativo que diga a identidade

${ }^{80}$ Cornford, Op. Cit. p 251

${ }^{81}$ Veja-se a nota anterior : Veja-se também Angioni, L. (2006) p 49: "Em Da Interpretação 3, 16 b 22-25, Aristóteles deixa claro que "ser" e "não-ser" não significam termos que tenham algum significado próprio, mas apenas "co-significam" uma certa composição — a composição entre o sujeito e o predicado de uma sentença - a qual não é possível inteligir sem os itens conectados. (...) [Ser] jamais pode ser utilizado para denotar uma coisa, ou classe de coisas, ou mesmo um fato ou uma classe de fatos". 
da coisa, ou seja, aquilo mesmo que ela precisamente é em si e por si $^{82}$, e um uso de "é" que exige um predicativo que diga algo outro do que já está constituído como sujeito da predicação $^{83}$. Ou seja, a distinção fundamental para Aristóteles consiste em discriminar que, A sendo B, ele o é ou kath' autò ou kat' allou (segundo o mesmo ou segundo o outro). Nem eleatas nem heraclitianos, segundo Aristóteles, fazem corretamente esta distinção entre afirmar ou negar o mesmo, ou seja, pensar e dizer algo segundo a identidade (dizer "é" ou "não é" na categoria da quididade ou essência), e afirmar ou negar o outro, ou seja, pensar e dizer algo segundo a alteridade (dizer "é" ou "não é” em qualquer uma das outras categorias).

${ }^{82}$ Metafísica, VII, 3, 1029a 7: "Assim, está dito agora, em seu traço geral, o que é porventura a essência: que ela é aquilo que não é afirmado de subjacente, mas sim aquilo de que os outros são afirmados". Tradução de Angioni, L. Op. Cit. p 19. Refiro-me preferencialmente a Zeta-3, e não ao tratado das Categorias, justamente porque, diferentemente deste último — que está preocupado em mostrar (contra Platão?) que os predicados essenciais não existem fora dos indivíduos singulares, sendo, pois, 'substâncias segundas' —, Zeta-3, por sua vez, salienta que os individuos, 'substâncias primeiras' $(x)$, para figurarem como sujeitos de uma proposição, precisam ser previamente identificados como sendo, discriminadamente, um isto (A), do qual, então, e só então, se poderá dizer que também são tal ou qual (B). Quando Zeta-3 afirma que a essência (ousia) não se diz de um subjacente, a essencia não é o indivíduo $x$, composto de matéria e forma (Cf. 1029a 26-33), como levava a crer o tratado das Categorias (pois o composto é posterior, ao passo que a essência é algo primeiro, ao qual os predicados pertencem). Ademais, esse primeiro também não é a matéria (porque esta não é algo determinável separadamente e 'um isto' - Cf. idem ibidem), mas sim a forma (eidos), ou seja, a substância segunda (o que valoriza, para meu proveito, certos fios de continuidade entre o pensamento de Platão e Aristóteles). Mas, o que, então, em Zeta-3, quer dizer que a essência (como eidos) não é dita de um subjacente? Ora quando se diz que A é B, mas B é um predicado essencial ("é" na categoria da quididade) e, portanto não é dito de um subjacente, isso significa que B não é algo que se diz de A como se A já se constituísse como tal — ou seja, como um subjacente - sem ele. Por outras palavras, quando a predicação é essencial, o predicado (B) não diz algo de algo subjacente mas, antes, diz o próprio subjacente, como quando se diz que "homem (A) é racional (B)", pois isso é o mesmo que dizer que "animal racional é racional" (o racional présupondo, ademais, o ser animado), e portanto, se diz o mesmo A e uma unidade e não o outro e uma heterogeneidade, como se dissesse que "homem é branco". Voltarei a isso logo mais, ao comentar a defesa aristotélica do princípio de não-contradição. Em tempo: devo a Lucas Angioni — seja através da leitura de seus minuciosos livros e artigos, seja através de seus ensinamentos orais, não menos precisos e rigorosos - a compreensão, além de tantos outros esclarecimentos sobre a filosofia de Aristóteles, da distinção entre dizer o subjacente (que é o que faz apenas a predicação da essência), e dizer de um subjacente (que é a predicação não essencial se limita a fazer). A leitura de Introdução à teoria da predicação em Aristóteles (já em sua primeira versão, na coleção Textos Didáticos, no. 41, de 2000) foi absolutamente essencial para a elaboração de minha tese. Para o ponto aqui em pauta, reporto-me a Angioni, L. "Não ser dito de um subjacente", "um isto" e "separado": O conceito de essência como subjacente e forma (Z-3)" in Cadernos de História e Filosofia da Ciência - Filosofia Antiga, CLEUNICAMP, Serie 3, Vol. 8, nº. Especial Jan-Dez 1998, pp 69-123. Evidentemente, minha dívida para com Lucas Angioni não deve, porém, significar que meus eventuais erros também lhe sejam creditados.

${ }^{83}$ Cf. Metafísica, 1029 b 22 - 1030a 4, na mesma tradução de Angioni: “o outro modo de dizer algo não 'por si mesmo' (ou kath' autò) se diz pelo fato de estar acrescentada outra coisa àquilo mesmo que se define (...) O 'quê era ser' é aquilo precisamente que 'um algo' é; entretanto, quando um outro se afirma de um outro (allo kat' allou légétai), o conjunto que assim se diz não é aquilo que precisamente 'um certo isto' é; por exemplo, o 'homem branco' não é aquilo precisamente que um certo isto é, se o 'isto' pertence tão somente às essências; de modo que há 'quê era ser' de tudo aquilo cujo enunciado é definição. E um enunciado é definição não se um nome significar o mesmo que um enunciado (...) mas sim se o enunciado for de algo primeiro: e é de tal tipo tudo aquilo que se diz não pelo fato de um outro ser afirmado de um outro (allo kat' állou)" p 24; itálicos meus. 
Quanto aos eleatas, veja-se, por exemplo, os capítulos 2 e 3 do Livro I da Física, onde Aristóteles discute a possibilidade desta ciência contra Parmênides e Melisso, os quais, pretendendo que o ente seja uno e imóvel, eliminam as determinações sob as quais o ente se faz objeto da física. Ora, o que Aristóteles volta contra essa doutrina é justamente a tese de que "o próprio Um se diz multiplamente (legetai pollachós), tal como o ente" (185b 5), donde ser necessário examinar em que sentido são usados os termos 'Um’ e 'múltiplo'. A exposição alcança um nível explicitamente lógico, no qual a multiplicidade dos entes é considerada segundo o enunciado (é lógói): “por exemplo, é diverso (lit.: é outro, állo) 'ser branco' e 'ser culto', mas uma mesma coisa (e.g. Sócrates) é ambos (sc. branco e culto); ora, o Um então é muitas coisas (pollà ára tò bén)" (185b 32). Na seqüência, Aristóteles diagnostica que o erro de Parmênides não é outro senão assumir que "o ente é dito de modo simples" (haplós tò òn légesthai), e desenvolve uma refutação do eleatismo sempre mostrando os absurdos que se seguem de não haver Parmênides diferenciado entre o ente tomado como precisamente aquilo que ente é (ou seja, ente na categoria da quididade) e o ente que se diz de um subjacente (ou seja, o ente nas demais categorias), este último sendo, aliás, chamado "um certo ente" (òn ti). Quanto ao não-ente, os desenvolvimentos finais do capítulo 3 também estão de acordo com os resultados a que vimos chegar Platão no Sofista:

"não é verdade que, se o ente significa um e não é possível que a contradição seja verdadeira ao mesmo tempo, não há nenhum nãoente: pois nada impede que o não-ente seja, não simplesmente sem mais (mé haplós), mas um certo não-ente (mé ón ti)" 84

Contra os heraclitianos, Aristóteles, como já mencionei brevemente mais acima, desenvolve uma engenhosa argumentação nos capítulos 3 e 4 do Livro Gamma da Metafísica. Ao final do capítulo 3 (1005b 25), Heráclito é nominalmente referido como alguém que teria afirmado ser possível admitir (bupolambánein) que o mesmo algo (tautòn) é e não-é (eînai kai mé eînai). Algumas observações preliminares devem ser feitas a esse respeito. Por ser uma paráfrase abreviada da negação do princípio de nãocontradição (PNC), a frase poderia dar margem a uma leitura existencial do verbo "ser" aí empregado: 'Heráclito teria afirmado ser possível admitir que o mesmo existe e não

\footnotetext{
${ }^{84}$ Aristóteles, Física 187a 5. Para esta citação e para todo o parágrafo que a antecede no corpo do meu texto, segui a tradução de Lucas Angioni em Física I e II. Col. Textos Didáticos, no. 34. Campinas, IFCH/UNICAMP, 1999, pp 23-29.
} 
existe'. Mas não é disso que se trata. O PNC, tal como apresentado algumas linhas antes, em 1005b 19, afirma que é impossível (adúnaton) atribuir e não atribuir (bupárchein te kaì mé hupárchein) ${ }^{85}$ o mesmo (tò autò) ao mesmo (tói autói), em um mesmo tempo (háma) e no mesmo sentido (kata tò autò). Trata-se, pois, de uma acepção predicativa do verbo ser, como se vê tanto pela alternância entre eînai (ser) e hupárchein (ser atribuído a, acontecer a), quanto pela presença de um objeto (ser atribuído ou acontecer a um mesmo $=$ tó $_{i}$ autói) para este segundo verbo, indicando o caráter elíptico daquela primeira paráfrase (como também se passa com outras ao longo do texto). Num momento mais avançado da argumentação aristotélica, no capítulo 4 (1006b 34), o PNC aparecerá instanciado por um caso paradigmático, no qual o caráter predicativo é evidente: "não é admissível (ouk endéchetai) dizer (eipeîn) verdadeiramente (aléthès) que o mesmo (tò autò) é (eînai) homem (ànthrópon) e não é homem (mé eînai ànthrópon) em simultâneo (báma)". É a partir deste último exemplo que será possível — contra Cornford - explicitar as conexões com a problemática do Sofista e, finalmente, com todo o percurso que veio sendo desenvolvido até aqui. Entretanto, já na altura da referência a Heráclito, ao final do capítulo 3, algumas primeiras conexões com tais desenvolvimentos anteriores também podem ser percebidas. Aristóteles, por exemplo, diagnostica que, recusado o PNC, um mesmo homem teria ao mesmo tempo as opiniões contrárias (hama gar àn échoi tàs enantías dóxas), exatamente como ocorreria, segundo Bayle, com o Deus de Espinosa, entendido como sujeito de inerência dos pensamentos de todos os homens, pois, entre tais pensamentos, uns são contrários aos outros. E a primeira observação que Aristóteles faz contra isso - "não é necessário que alguém também admita (bupolambánein) o que diz (légei)" (1005b 25) — se vale do mesmo tipo de distinção entre falar (phteggesthai) e propriamente dizer (légein), que comparece no Sofista $(237 \mathrm{e} 4)^{86}$, e aponta para a

${ }^{85}$ A tradução latina de Moerbeke usa "esse et non esse", o que é licitado tanto pelas possibilidades do verbo grego bupárchó quanto por paráfrases — como a supra citada — que o próprio Aristóteles faz nas imediações do mesmo texto. Todavia, no interior da própria tradução latina, é indelével a presença dos dois termos articulado pelos infinitivos: de um lado idem, desempenhando o papel de predicado, de outro, in eodem, desempenhando o papel de sujeito.

${ }^{86}$ Esta distinção do Sofista foi comentada acima na nota ; onde explicitei que o 'falar' a que se refere Platão talvez fosse mais literalmente traduzido por vocalizar (phteggesthai). Note-se que o verbo lego - cuja grande plasticidade semântica é bem conhecida — desempenha papeis alternados nos argumentos de Platão e de Aristóteles. Os aparentes problemas que isso me traria se disfazem, sem maiores dificuldades, se se atentar à função que o verbo cumpre em cada um dos contextos citados: no Sofista, contraposto a 'vocalizar' (phteggesthai), 'dizer' (légein) significa 'dizer com sentido', e na Metafísica, contraposto a 'admitir' (bupolambánein), 'dizer' (légein) significa apenas 'falar'. O que é patente, em ambos os caso, é a contraposição entre uma fala não comprometida com a veiculação de um sentido e uma outra que se caracteriza precisamente por essa veiculação. 
significação como sendo o parâmetro decisivo para a refutação a ser empreendida na seqüência.

Feitas essa observações preliminares, ainda cumpre apresentar as dificuldades formais e dialógico-pragmáticas que se impõem à argumentação subseqüente em favor do PNC. Tais dificuldades consistem em demonstrar o PNC sem que se cometa uma petição de princípio, ou seja, sem que se cometa o erro formal que a personagem Zenão, do diálogo Parmênides, teria cometido se não houvesse, com prudência, se limitado a "devolver a mesma coisa" aos que atacam o Um, colocando, aporeticamente, ambas as posições em pé de igualdade ${ }^{87}$. Afinal, não se pode demonstrar o PNC através de uma redução ao absurdo, se o absurdo a que se chega for justamente uma contradição, pois o que está em questão é precisamente saber se contradições são ou não são absurdas. Do ponto de vista dialógico-pragmático, a mesma dificuldade formal pode ser traduzida da seguinte maneira: do que adiantaria levar à contradição aqueles que afirmam que contradições não são perniciosas ${ }^{88}$ ? Refutá-los por contradição seria, por assim dizer, tentar apagar o fogo heraclitiano com o próprio combustível que o alimenta. Por outro lado, tampouco se pode demonstrar positiva ou diretamente o PNC, pois é ele que controla todo procedimento demonstrativo e garante a necessidade que caracteriza tal procedimento ao determinar que proposições contraditórias não podem ser verdadeiras ao mesmo tempo (que é a regra básica para o funcionamento do conhecido quadrado das oposições de Aristóteles). Assim, entre, de um lado, a petição de princípio, resultante de tentar provar demonstrativamente o princípio pressuposto em toda demonstração, e de outo, a impropriedade de tentar levar o adversário heraclitiano à contradição, Aristóteles desenvolve uma refutação que eu chamaria de demonstração por implicação performativa ou por redução ao inexorável. Trata-se de mostrar que, ao recusar o PNC, aquilo que os adversários fazem, no ato mesmo de realizar tal recusa, veicula a declaração tácita — independente daquilo que falam — de que já aceitaram o princípio (trata-se, por isso, uma implicação performativa, e não exatamente de uma contradição performativa, visto que é inócuo e inválido apelar aqui a qualquer tipo de contradição, mesmo que ela de fato ocorra $)^{89}$. Aristóteles "estabelece a validade

\footnotetext{
${ }^{87}$ Cf. Supra

${ }^{88}$ Cf. Aubenque, P (1987) p 122: “em nome de que, senão do princípio de não-contradição, objetamos suas contradições aos adversários que negam precisamente esse princípio?”

89 Numa contradição performativa, os elementos em contradição não são duas ou mais declarações distintas, produzidas por dois ou mais atos de fala ou de pensamento, mas sim uma contradição entre duas dimensões internas a um único e mesmo ato, a saber, entre seu conteúdo (o que se diz ou pensa) e sua "forma", isto é, seu perfazimento efetivo (que se diz ou pensa, isto é, o fato de dizer
} 
necessária do princípio na base da impossibilidade de sua transgressão" "90 (trata-se, por isso, de uma redução ao inexorável, visto que, novamente, apelar ao absurdo, entendido como o contraditório, é inócuo e inválido). Portanto, Aristóteles não está acusando de contraditórios aqueles que não se incomodariam com isso, nem tampouco incorrendo em petição de princípio, ele está, antes, mostrando como estes outros, eles sim, incorrem em tal petição, pois, a fim de argumentar, se valem, ipso facto, daquilo mesmo que puseram em questão; o adversário não é culpado por contradizer-se, mas sim por ser dogmático, por postular, sub-repticiamente, aquilo mesmo que se esforça por criticar $^{91}$.

ou pensar atualmente). Isto só é possível mediante duas condições, uma para cada dimensão em jogo: o ato deve ser, ele próprio, o veiculador de uma informação independente e o conteúdo, por seu turno, deve incluir alguma informação relevante sobre o próprio ato que a contém. Por exemplo: se alguém, diante da casa de um amigo, pergunta "fulano, você está aí?" e obtém, proveniente da casa e da parte do próprio fulano, a resposta "não", tal resposta constitui uma contradição performativa porque o que fulano diz falando (não estou em casa) ele contradiz fazendo (responder, ele mesmo, de dentro de casa, veicula a mensagem independente: "eu estou em casa"). Quanto à pergunta, solicito que seja entendida em seu uso mais ordinário e costumeiro; mas, se se objetar que ela já é formulada de maneira a facultar o despropósito, eu replicaria que não, pois o perguntador, no contexto, espera sua resposta sob o modo da simples ocorrência ou não ocorrência de resposta: fulano respondeu = ele está em casa, fulano não respondeu = ele não está em casa, o que, aliás, só reforça o fato de que um ato já pode ser suficiente para veicular uma informação independente). Mas a contradição só ocorre porque o conteúdo, o "o que" se diz, traz informações relevantes sobre o ato. Se alguém fala "eu não estou falando", comete uma contradição performativa, mas se fala "eu não estou sentado", não comete, pois, neste segundo caso, o conteúdo não reenvia a nenhum aspecto do próprio ato que o contém. Uma implicação performativa poderia ser, então, exemplificada pela relação entre o conteúdo e a forma de um enunciado do tipo "eu estou dizendo algo" (a saber, que estou dizendo algo). No caso do argumento em favor do PNC, falo de uma implicação performativa porque, embora haja, sim, uma contradição entre o que o heraclitiano diz falando e o que diz fazendo, o argumento deve basear-se exclusivamente no que ele diz fazendo. $\mathrm{O}$ argumento pretende ser válido não só para quem pretende diz "O PNC não é o caso" ou "recuso o PNC" — ato que, embora sem efeito sobre o heraclitiano, efetivamente consiste numa contradição performativa - mas também, como será visto logo a seguir, para quem quer que diga algo com sentido, não importando o que (quando ocorre uma implicação performativa: quem pensa e diz qualquer coisa significativamente veicula através deste ato, como mensagem independente, a declaração "eu estou dizendo algo significativamente"). Os desenvolvimentos subseqüentes serão, portanto, a explicitação da estrutura do dizer ou pensar algo significativamente e do modo como tal estrutura implica o PNC.

${ }^{90}$ Santos, L. H. L. Op. Cit. p. 445.

91 "O culpado (aítios) pela postulação não será o que demonstra, mas sim o que se submete [sc. ao argumento]. Pois ao pretender destruir o argumento, ele se submete ao argumento" (1006a 25 — Trad. de L. Angioni, modificada apenas na tradução de aítios, somente para reforçar que trata-se aí do erro pelo qual se pretende refutar o adversário, sem apelo a contradições). Essa formulação da estratégia refutativa aristotélica retoma, tal como a redigi no corpo do texto, praticamente as mesmas palavras que usei em um artigo de 1997. Cumpre, pois, fornecer a referência: Rezende, C. N. "Filosofia e linguagem em Nietzsche" in Cadernos Nietzsche, $\mathrm{N}^{\circ}$. 3. São Paulo, Discurso Editorial, 1997: "seria necessário proceder [sc. contra os heraclitianos] refutativamente, ou seja, mostrando como a afirmação do adversário se autodestrói pelo fato mesmo de que é feita. Mas em se tratando especificamente desse princípio das demonstraçãoes, mesmo tal procedimento refutativo encontra um primeiro limite, visto que de nada adiantaria indicar a contradição interna como razão da autodestruição de um argumento justamente a quem não aceita que contradições sejam perniciosas. A refutação que Aristóteles, então, apresenta, precisa ser, pois, de uma outra ordem (...) Indicando que, na ação mesma de querer dizer algo determinado, os negadores do princípio de não contradição se submetem e se servem do logos que sua atitude problematizava, Aristóteles não está acusando de contraditórios aqueles que não se incomodariam com isso, nem tampouco incorrendo em petição de princípio, ele está, antes, mostrando como estes 
Mas, afinal, o que fazem os adversários para que se dê essa aceitação tácita, imediata e inexorável do princípio de não-contradição? Ora, diz Aristóteles, eles realizam a ação de "significar algo (sémainein ti) para si mesmos ou para outrem (kai autói kai állói) (1006a 19). Se o adversário não perfizer essa ação, então, nada dirá para si mesmo ou para outrem, inclusive ao recusar o PNC, e não estará, pois, recusando coisa alguma. Recusar, negar, duvidar, discutir, ou apenas referir-se ao PNC ou ao que quer que seja, são ações que implicam a ação mais elementar de significar algo (sémaínein ti). Resta, pois, demonstrar que significar algo implica o PNC, de sorte que negar o PNC implique o PNC. Como prenunciado desde a menção a Heráclito, o pilar do argumento é, portanto, a estrutura da significação. Aristóteles analisa essa estrutura em um nível maximamente elementar, qual seja, aquele em que alguém ainda não profere uma "pretensão de verdade articulada sentencialmente",92, dizendo apenas um único onoma, uma única denominação (D), como, por exemplo, "homem",3 . Pois bem, para Aristóteles, mesmo quando o signo lingüístico é morfologicamente simples, seu sentido ou significação já implica, por assim dizer, a composição entre um sujeito e um predicado na mente: "a denominação (tò onoma) significa (sémaínei) [algo] ser (ou não ser) (ê̂nai é mé eînai) isto aqui (todî)"94 (1006a 28), "isto aqui" tendo a função de determinar que a denominação possui uma conotação definicional precisa, ou seja como explicará Aristóteles logo em seguida (1006a 31) — que a denominação significa algo uno (sémaínei hèn) ${ }^{95}$. O exemplo dado é: “se 'homem' significa algo uno, seja isso o

outros, eles sim, incorrem em tal petição - e uma atitude tão própria aos dogmáticos certamente incomodaria céticos e sofistas, pois, 'a fim de argumentar, se valem daquilo mesmo que puseram em questão"”. A última frase, entre aspas simples, provém de Aubenque, Op Cit. Loc. Cit.

92 "E o princípio contra todos os argumentos desse tipo não é exigir que [sc. o adversário] afirme (légein) que algo (ti) ou é ou não é (einai é mé eînai) [o caso]" (1006a 18). A paráfrase "pretensão de verdade articulada sentencialmente" para o tex to "afirmar que algo ou é ou não é [o caso]" provém de Angioni, L. Introdução à Teoria da Predicação, p 46. Aristóteles é explícito ao justificar essa cautela: "pois alguém poderia julgar que isso já é postular o que estava no princípio". Com efeito, se fosse exigido do adversário que ele assumisse alguma pretensão de verdade sentencialmente articulada, ou seja, uma tese qualquer (que $\mathrm{X}$ é o caso), em detrimento de outra (que não-X não é o caso), isso já seria começar por exigir aquilo mesmo que está em questão, ou seja, que o adversário não possa se contradizer, o que equivale, de novo, a uma petição de princípio por parte daquele que, desejando defender o PNC, faz tal exigência. $\mathrm{O}$ cerne da estratégia aristotélica está precisamente em se deslocar do comprometimento com a verdade de uma tese qualquer para o comprometimento com um sentido qualquer. Assim, recuando ao grau zero do sentido ou significação, Aristóteles procede, a fortiori, a partir de uma única palavra.

93 Nomes não devem ser confundidos com nomes próprios, como Fido, que, nomeando este cachorro aqui, funciona unicamente como uma etiqueta sonora, absolutamente convencional, destituída de qualquer sentido conotativo.

94 Trata-se - como advertido nas observações preliminares, feitas mais acima - de uma paráfrase elíptica, donde a incisão que fiz da palavra "algo".

95 O pronome todi representa o sentido da denominação, precisado na sua definição. Cf. Angioni, Introdução à teoria da predicação em Aristóteles, p. 50. 
'animal bípede"” (1006a 31-32). E a explicação do exemplo parece ser a seguinte: se homem (D) é isso (a saber, animal (a) + bípede (b)), e se algo (X) é homem (D), então este algo $(\mathrm{X})$ será aquilo $(a+b)$ que era o ser para homem (tò anthropo einai) ${ }^{96}$. Portanto, a despeito da simplicidade de $\mathrm{D}$, em seu interior encontra-se o pensamento de um X que é $a+b$. Assim, quando alguém pensa e diz a denominação D significando algo uno, esse alguém está transferindo para o que quer que receba a denominação - o que quer que instancie $\mathrm{X}$ - o exato conjunto de características $(a+b)$ que são a própria quididade ou definição de D: se Sócrates é homem, e se a denominação "homem" aí significa algo uno (a saber: animal bípede), então Sócrates é animal bípede. Consequentemente, se como querem os heraclitianos mencionados ao final do capítulo 3 (1005b 25) - fosse possível admitir (bupolambánein), e não apenas falar, que o mesmo X é e não é tal coisa $(a+b)$, então, $\mathrm{D}$ não significaria que $\mathrm{X}$ é isto aqui (todì) e, portanto, não seria uma denominação: "a denominação significa algo e significa algo uno; ora, então, não é admissível que o ser para homem signifique precisamente o não ser para homem" (1006b 11). Se D significasse tanto $a+b$ quanto tudo aquilo que não é $a+b$, todos os nomes seriam sinônimos e produzir-se-ia uma absoluta indiferenciação semântica: tudo significando tudo, nenhum nome realizaria a função de significar. Em suma, dada a complexidade interna, oculta sob a aparente simplicidade da denominação, quem realiza a ação de pensar o e dizer significativamente um único nome (D), já veicula, através desta ação, a declaração tácita: "eu estou dizendo isto aqui - a saber: um X que é $a+b$ - e não qualquer outra coisa". Se alguém nega o PNC, nada terá, então, a que direcionar seu pensamento, uma vez que nega que a quididade de cada coisa seja uma e a mesma; dessa maneira, ele destruirá completamente a capacidade de discutir, de falar e de pensar ${ }^{97}$. Destarte, se alguém diz significativamente D, já aceitou o PNC.

O caso, porém, ainda não está encerrado, pois os adversários poderiam voltar a própria arma aristotélica - a noção de significar algo uno (sémaínei hèn) - contra o PNC. O contra-argumento desses adversários possuiria, então, exatamente a mesma estrutura das dificuldades enfrentadas no Sofista a propósito da relação entre o ente e todos os predicados que exprimem uma essência: tantas vezes $\mathrm{X}$ possuísse predicados distintos de homem, que têm suas próprias quididades ou definições, tantas vezes $\mathrm{X}$

\footnotetext{
${ }^{96}$ Confira-se o comentário de Angioni a 1006a 32-34 (Idem supra, p 53-58).

${ }^{97}$ Esta é uma paráfrase que faço de um trecho do Parmênides de Platão: 135 b5 - c10, já citado em nota anterior (nota ). Inseri-la aqui constitui um argumento indireto, contra Cornford, a fim de salientar a unidade das dificuldades enfrentadas e das estratégias de solução encontradas pela doutrina aristotélica das categorias e pelos diálogos lógicos de Platão (como o Parmênides e o Sofista).
} 
também seria não-homem ${ }^{98}$. E a resposta aristotélica, mais uma vez apontando para a doutrina das categorias, possuirá a mesma estrutura da resposta platônica, na medida em que $\mathrm{X}$ seria esses não-homens (e.g. branco ou músico) num sentido diverso daquele pelo qual $\mathrm{X}$ é homem. O contra-argumento heraclitiano poderia ser assim resumido:

(i) X é homem

(ii) $\mathrm{X}$ é branco

(iii) branco não é homem

(iv) Logo, $\mathrm{X}$ é e não é homem.

Onde está o núcleo do sofisma? Ora, está no ocultamento da variação do uso da própria cópula: o verbo “é” não realiza a mesma operação lógica, não estabelece o mesmo tipo de relação entre os sujeitos e o predicados, ao longo do raciocínio. Em (i) e (iii), "é" e "não é" estipulam que o predicado signifique algo uno; ou seja, em (i), "é" afirma que a quididade ou definição de homem (animal bípede) é aquilo que $\mathrm{X}$ é, e em (iii), "não é" nega que a quididade ou definição de homem (animal bípede) seja aquilo que branco é (por exemplo: cor $(c)+$ de tal tipo $(t)$ ). Todavia, para concluir que (iv) é uma autêntica contradição, o heraclitiano precisa supor que, em (ii), a cópula também introduz um predicado que transmite sua própria quididade ou definição $(c+t)$ para o sujeito X. Portanto, é apenas mediante a autorização de que se traduza, na premissa (ii), "Sócrates é branco" por "Sócrates é cor tal", que haveria contradição em (iv), pois somente assim colidiriam em $\mathrm{X}$ duas quididades: o ser precisamente homem $(a+b)$ e o não ser homem mas sim precisamente outra coisa $(c+t)$. O sofisma baseia-se justamente na - errônea - suposição de que, em todas as premissas, o "é" e o "não é" introduzem predicados que significam algo uno (sémainei hèn) ${ }^{99}$. É por isso que se pode considerar que os adversários estariam, desta vez, usando a própria arma que fora empregada contra eles no primeiro argumento aristotélico. Todavia, a cópula, em (ii), abre lugar para um predicado que - segundo a terminologia de Aristóteles neste contexto — não

${ }^{98} \mathrm{Na}$ linguagem de Luís Henrique dos Santos (cf. supra, nota ), o que estou dizendo é que, a partir de 1006b 11, o livro Gamma da Metafísica de Aristóteles enfrenta, no confronto com os heraclitianos, um argumento estruturalmente idêntico ao "paradoxo do verdadeiro", de origem eleata (atribuído a Antístenes), que fora enfrentado por Platão no Sofista. O que me ocorre, então, notar, é a equivalência entre os antípodas, isto é, entre eleatas e heraclitianos: os primeiros, afirmando que o ente é e o não-ente não é, e os segundos, afirmando que o não-ente é e o ente não é, parecem, não obstante, compartilhar uma concepção igualmente rígida dessas duas noções (ser e não ser).

99 É isso que exprimi com a introdução do adverbio "precisamente" na paráfrase da linha anterior. 
significa algo uno (sémaínei hèn) mas apenas "a respeito de algo uno" (sémainein tò kath henós - 1006b 14). Para que o sofisma se desfaça, esta última expressão deve corresponder a um sentido menos estrito - mais generoso — de "é": Sócrates é branco, mas nem por isso é uma cor, e pode, portanto, continuar sendo, ao mesmo tempo que branco, o animal bípede que ele precisamente é ${ }^{100}$. Por outras palavras: se o homem que Sócrates não é enquanto branco não colide, não exclui, não concorre com o homem que Sócrates é enquanto homem, é porque o homem que Sócrates não é e o homem que Sócrates é não são ditos ou pensados de Sócrates na mesma relação, no mesmo sentido. É por isso que não há em (iv) uma autêntica contradição: só há contradição quando o mesmo (e.g. homem) é e não é no mesmo (e.g. Sócrates), ao mesmo tempo e num mesmo sentido de ser, ou seja, em uma mesma categoria. E assim, a plena demonstração do PNC depende da doutrina das categorias.

Este é o cerne da versão aristotélica do gesto que poderia ser tomado por um parricídio. Na lógica de Aristóteles, o principal golpe contra o pai encontra-se expresso na última cláusula do PNC. Aliás, introduzir quaisquer cláusulas em um princípio já é, de saída, limitá-lo, sem, no entanto, recusá-lo por completo ${ }^{101}$. E aqui é preciso bem entender, então, qual seja "o mais firme", o "mais certo", o "mais cognoscível” de todos os princípios da lógica clássica ${ }^{102}$ : o PNC é o princípio que determina em que condições o mesmo é e não é, sem que se destrua o pensamento e a linguagem. Com efeito, Aristóteles introduz, pelo menos, três cláusulas em sua versão do PNC:

(cl) a cláusula da identidade do sujeito (em grego: tó autó $_{i}$ / em latim: in eodem) ${ }^{103}$

${ }^{100}$ Cf. supra, nota : semainein hén equivale à condição de o predicado não ser afirmado de um subjacente (que é o que caracteriza a essência), e sémaínein kath' henós, equivale a ser afirmado de um subjacente: o subjacente seria o algo uno, já constitído em seu tipo identidade própria, acerca do qual, então, se afirma o predicado que o pressupõe mas não o define (que é o que caracteriza o acidente).

101 O termo "cláusula" me parece um substantivo apropriado para traduzir as formas verbais, derivadas de prodiorizó, que Aristóteles emprega em 1005b 20-21 e 27 ao falar de "fazer especificações em acréscimo" ao PNC. No interior de prodiorizó está o verbo horizo, (raiz da palavra portuguesa horizonte) que significa delimitar, assim como na palavra latina clausula - derivada do verbo claudere $=$ fechar, donde vem, por exemplo, a palavra portuguesa clausura — está a idéia de "pequeno fechamento", ou seja, de restrição ou delimitação. De qualquer forma, para além da etimologia, parece-me evidente que, de um ponto de vista lógico, quem diz "é proibido fumar" faz uma proibição muito mais ampla do que quem diz "é proibido fumar cigarros, nesta sala, pela manhã": fumaremos, pois, nesta sala, pela manhã, cachimbos; ou fumaremos cigarros, pela manhã, em outra sala; ou fumaremos, nesta sala, cigarros, depois de passada a manhã. A segunda frase diz, portanto, que é permitido fumar, delimitados em acréscimo o que, onde e quando, muito embora não diga, simples e absolutamente, que não é proibido fumar.

102 Veja-se Metafísica, Gamma 3, 1005b 5-16. Aristóteles não fala de princípios lógicos, mas sim de "princípios dos silogismos"; todavia, não creio que isso interdite minha formulação.

${ }^{103}$ Forneço aqui o equivalente latino da tradução de Moerbeke. 
(c2) a cláusula da identidade do tempo (em grego: háma / em latim: simul)

(c3) a cláusula da identidade categorial (em grego: katà tò autó / em latim: secundum idem $)^{104}$

O PNC, enquanto fundamento da lógica clássica, sistematizada por Aristóteles, não é o princípio da identidade mas sim da alteridade; ele não vem estabelecer, como a lei de Parmênides, a pura tautologia $(\mathrm{A}=\mathrm{A})$, mas sim, para além dela, uma identidade na alteridade (A é B ou, se se preferir, S é P). Para evitar a contradição estrita, que é a destruição do pensamento e da linguagem, - justamente porque a contradição tudo indiferencia —, o princípio de não contradição é o cerne de uma lógica da diferença, que é também uma lógica do sentido. Para proteger o pensamento e a linguagem da indiferença generalizada, da trivialização dissolutiva do sentido, o PNC determina que o mesmo é e não é, revelando-se, (pela cláusula $c 1$ ) o princípio da diferenciação das substâncias, (pela cláusula c2) o princípio da diferenciação do tempo, e (pela cláusula c3) o princípio da diferenciação das maneiras de afirmar e negar ou, por outras palavras, o princípio da polissemia categorial do "é" e do "não é". É claro que ainda se trata do princípio da não-contradição, mas aquilo que ele delimita como contradição é algo muitíssimo mais restrito do que parecem haver considerado tanto eleatas quanto heraclitianos, pois esta noção só se caracteriza quando as três cláusulas - e outras que por ventura houver — forem desobedecidas.

De tais flexibilizações do monolítico PNC eleata, é a terceira a que mais me interessa. É ela que demonstra, contra Cornford e a favor de Wolff, ao menos um fio de ligação - mas um fio essencial! - entre a doutrina aristotélica das categorias e a doutrina platônica dos grandes gêneros. Retornemos mais uma vez - muito brevemente - ao Sofista, agora de posse desse fio de Ariadne, e perguntemos: como se enunciava o suposto parricídio? Ora, como estabelecimento de que "o não-ente, sob certa relação (katá ti), é, e que o ente, por sua vez, de algum modo (péi), não é”. Esta preposição katá e este advérbio péi são os antepassado platônicos da terceira cláusula

${ }^{104}$ Se pelo menos uma delas não for atendida, não haverá contradição mas alguma outra relação lógica. Por exemplo: ( $c 1$ não atendida) $=\mathrm{O}$ mesmo (e.g. homem) é e não é, ao mesmo tempo e no mesmo sentido (e.g. significando algo uno), mas não no mesmo sujeito (e.g. Sócrates é o que homem precisamente é e, ao mesmo tempo, Fido não é homem o que homem precisamente é mas cachorro); (c2 não atendida) $=\mathrm{O}$ mesmo (e.g. doce) é e não é, no mesmo sentido (significando a respeito de algo uno), no mesmo sujeito (este vinho), mas não ao mesmo tempo (ha cinco dias este vinho era doce e hoje é ácido); (c3 não atendida) $=\mathrm{O}$ mesmo (e.g. homem) é e não é, no mesmo sujeito (e.g. Sócrates), ao mesmo tempo, mas não no mesmo sentido (é homem na categoria da quididade e não é homem, mas branco, na categoria da qualidade). 
aristotélica. E esta não é uma ocorrência isolada. No Sofista, bem no interior da discussão sobre os grandes gêneros e suas relações mútuas, verificam-se outros exemplos que atestam, não a identidade entre os gêneros platônicos e as categorias aristotélicas mas, como dito anteriormente, a semelhante função argumentativa que tais noções desempenham em seus respectivos contextos de uso. Chamo atenção, pois, para partículas sincategoremáticas, advérbios e outros elementos que - como katá e pé - se fazem presentes na condição de operadores no texto platônico. Em 255e, depois de apresentados os 5 grandes gêneros — ente, movimento, repouso, mesmo e outro Platão toma um dentre eles, o movimento, para exemplificar como tais gêneros se relacionam entre si. $\mathrm{Na}$ passagem em que se conclui o exame da relação entre o movimento e o mesmo (256a 11), uma frase se destaca e inaugura um novo sentimento a respeito dos ataques realizados contra a intransigência do pai Parmênides:

"Devemos confirmar (bomologétéon) e sem nos afligir (kaì ou duscherantéon) que o movimento é o mesmo (kinésin tautón eînai) e não o mesmo (kaì mé tauton); pois, quando o dizemos "mesmo" e "não mesmo" não dizemos da mesma maneira (ou homoíos)"

O movimento é o mesmo porque é o mesmo que si mesmo; mas não é precisamente aquilo que a idéia do mesmo é, ou seja, movimento não é mesmidade, já que o repouso, sendo também, de sua parte, o mesmo que si mesmo, também participa da mesmidade; de sorte que, se movimento fosse precisamente o que mesmidade é, o repouso seria móvel e o movimento, imóvel, levando à destruição de ambos. Assim, quando o Estrangeiro de Eleia assere que (i') "o movimento é o mesmo" e que (ii') "o movimento não é o mesmo", nesta segunda asserção - como em "branco não é homem" - "não é" nega que a quididade ou definição de mesmo (a mesmidade) seja aquilo que movimento é; e na primeira asserção - assim como em "Sócrates é branco" — não se emprega "ser" (eînai) dessa mesma maneira (homoíós). Nas relações entre o movimento e o outro (256c 9), a mesma estratégia argumentativa se repete, desta vez sem o advérbio homoiós, mas com o advérbio péi: “[o movimento] é de certa maneira (estí $p e ́$ ) tanto não outro quanto outro (ouk héteron kai héteron)". E isso é o que também ocorre na passagem (256d 7) sobre as relações entre movimento e ente: "Estrangeiro: - É, pois, sem temor (adeós) que combateremos (diamachómenoi), dizendo que o movimento é outro que o ente (béteron eînai toû óntos)? Teeteto: - Sem qualquer temor (Adeéstata)". E de onde vem essa tranqüilidade de afirmar — como se diz logo depois (em 256d 7) — que 
“o movimento, realmente (óntós) não é ente (ouk ón esti), mas também é ente (kai ón) na medida em que (epeiper) participa do ente (metéchei tố óntos)"? Ora, a resposta encontra-se na própria frase, sob a forma deste advérbio epeíper, traduzido como "na medida em $q u e "$. Todo esse novo contexto lógico-afetivo, marcado ao mesmo tempo pelo combate contra a tese do pai mas também pela ausência de aflição e medo ${ }^{105}$, vem de que, conquanto o movimento e todos os outros gêneros sejam não-entes, isso se dá segundo uma relação (kata) distinta daquela pela qual são entes (256d 10). Veja-se, pois, a seguinte formulação platônica, na qual todo esse trabalho sincategoremático e adverbial se exprime, de modo definitivo, através do mesmo termo - pollachós - que se tornou célebre no já citado bordão aristotélico de que "o ente se diz em muitos sentidos":

“desse modo (bóste) o ente, incontestavelmente (anamhpisbététós), milhares e milhares de vezes não é, e os outros, tanto cada um deles quanto todos em conjunto, por um lado, de muitas maneiras (ou em muitos sentidos $=$ pollaché $e_{i}$ ) são, e por outro, de muitas maneiras (ou em muitos sentidos $=$ pollaché $i$ ) não são"106.

As simultâneas tranqüilidade e segurança na desobediência (épistékamen) da proibição (aporrésis) parmenídica (258c 8) decorrem do fato de que a posição defendida não redunda na admissão de algum contrário (enantiou tinos) do ente (259a) que seria como o nada, pois o não-ente que se admitiu (258e) tem a natureza do outro, a qual toma parte do conjunto das formas e encontra-se distribuída (katakekermatisménen) nas relações recíprocas entre todos os entes (epì tà ónta pròs alléla). É por isso que se pode, então, duvidar da real ocorrência do pretenso crime de parricídio ${ }^{107}$. Alguns golpes de fato foram desferidos contra o pai, mas, em primeiro lugar, parecem ter sido praticados em legítima defesa do direito de pensar e dizer algo com sentido (direito de que inclusive a autoridade paterna se beneficia) e, em segundo lugar, não resultaram em morte, pois ninguém, nem Platão nem Aristóteles, afirmou o ser do nada. Muito pelo contrário, protegendo o pai contra sua própria intransigência, impediram, de um lado, que o espírito da lei fosse corrompido pelo uso que os sofistas puderam fazer de sua letra, e de outro, impediram que, ao invés da pura retórica, também se estabelecesse o

${ }^{105} \mathrm{O}$ mesmo termo duscherantéon, comparece em 257a 9.

106 259b 4. Segui aqui, principalmente, a tradução de Cruz Costa e Jorge Paleikat.

107 É Wolff quem - mencionando também, como único comparte nesta posição S. Rosen (Plato's Sophist, The drama of original and image, Yale University Press, New Haven \& London 1983) — duvida de que houve realmente o tal parricídio. Cf. Op. Cit. p 198-202. 
puro silêncio como alternativa à tautologia, salvaguardando a possibilidade de um logos sobre o òn, isto é, de uma ontologia, atendendo à mesma tese paterna de que não é senão o ente o que há para ser pensado, conhecido e dito.

Aristóteles, no início do capítulo 3 do livro Gamma da Metafísica (1005a 191005b 16), atribui ao filósofo o exame daquilo que pertence ao ente enquanto ente, deduzindo daí que também lhe cabe examinar os axiomas e os princípios lógicos, dentre os quais o mais firme é o PNC. Ora, a ciência do ente enquanto ente, dada sua pretensão de objetividade, tem por compromisso "determinar os tipos de fatos complexos que existem no mundo e que, no plano da linguagem, resultam em diferentes tipos de composição entre sujeito e predicado, ou seja, em diferentes tipos de predicação"108. Cabe, portanto, ao filósofo, na dimensão ontológica de seu trabalho, discernir os diversos estados de coisas que correspondem aos diversos tipos de entrelaçamento condicionados pelas cláusulas do PNC. Isso quer dizer que o PNC, assim como zela contra o silêncio e a tautologia eleatas, zela também, no plano ontológico, pela recusa de um espaço metafísico absolutamente liso e homogêneo: tal como o PNC espera que as coisas sejam para que se lhe correspondam, elas devem, por assim dizer, copular ontologicamente ou, se se preferir, manter alguma sorte de comércio ontológico, no seio de uma realidade múltipla e móvel que também pode ser chamada de natureza ( $p$ husis).

Platão, no Sofista (259a 4), diz algo muito próximo disso, ao admitir que há uma mistura recíproca dos gêneros (summignutaí te allélois tà gén) e que o ente e o outro atravessam (penetram, invadem: dieléluthóta) um ao outro e todos os demais. Mais ainda: Platão também atribui ao filósofo, em contraste com o sofista, o conhecimento das diferenças, concordâncias e oposições entre as coisas, pois nem tudo se presta à mútua associação (252e). O filósofo é, então, comparado ao o músico e ao o gramático, porque o primeiro possui uma técnica de combinação harmônica dos sons, e o segundo, uma técnica de combinação ordenada das letras, sendo, por isso, capaz de discernir aquelas que, como as vogais, são ligações (desmòs) que se alastram através de todas as outras (dià pántôn kechôrêkeen), e aquelas que, como as consoantes, dividem e modificam as vogais, dando ao discurso simultâneas continuidade e diferenciação, isto é, articulação (253e). Analogamente ao gramático, que conhece a trama ou entrelaçamento dos elementos lingüísticos, o filósofo é dito possuir uma ciência suprema (megistês epistêmês), que conhece a correta articulação das estruturas tanto do pensamento e da realidade. Trata-

${ }^{108}$ Angioni, L. Introdução à teoria da predicação em Aristóteles; Introdução, p. 23. 
se de uma ciência de homens livres (epistêmên tôn eleutérôn), capazes de uma atividade diacrítica, pela qual se evita que uma mesma Idéia ou Forma (eidos) seja tomada por outra ou que uma outra seja tomada pela mesma. E não é sem propósito lembrar aqui de uma conhecida passagem do Fedro $(265 \mathrm{e} 1 ; 270 \mathrm{c}-\mathrm{e})$ em que a dialética não é comparada com a musica e a gramática mas, dessa vez, com a anatomia e o método da medicina hipocrática, indicando que o bom dialético deve proceder como o bom açougueiro e cortar as partes de um corpo segundo suas articulações naturais (kat' árthra), deslindando — por que não dizer? - a nervura do real ${ }^{109}$. Praticar tal arte é, nos termos do Sofista (259c-e), seguir cuidadosamente cada argumento, quer ele diga ser o mesmo o que, de certa maneira $\left(p e_{i}\right)$, é outro, ou diga ser outro o que, de certa maneira, é o mesmo, refutando-o ou aceitando-o segundo a relação própria (ekeinể kaì ekeeino) que o argumento assume em cada um desses casos. Platão, aliás, indiretamente sugere uma contraposição entre esse procedimento e a dialética praticada, por exemplo, por Zenão, dizendo que mostrar, não importa de que maneira, que o outro é o mesmo (to thateron tauton), que o grande é pequeno (to mega smikron) e que semelhante é dissemelhante (to hómoion anómoion), não é verdadeira refutação, mas "o fruto prematuro de um primeiro contato com o real". Seguir a nervura do real sabendo diferenciar as diversas maneiras de afirmar e negar é o que, segundo a letra do texto platônico, "é ao mesmo tempo tão difícil quanto belo" (kai chalepon báma kai kalón).

E mesmo Cornford reconhece que "com certa razão", se pode dizer que, então, estamos diante de uma lógica:

${ }^{109}$ Aludo aqui ao título da já citada obra de Marilena Chauí, a quem devo boa parte de minha formação nos estudos espinosanos. A presente alusão possui um duplo sentido: por um lado, trata-se de uma homenagem e do reconhecimento da presença de meu diálogo com a autora e sua obra, ao longo desta tese; por outro lado, trata-se também de uma gentil provocação, pois, afinal de contas, estou arrastando a expressão "nervura do real" para um universo platônico-aristotélico, particularmente marcado pela dependência da ontologia com relação à lógica, contrariamente à tendência de Chauí. Porém, como já tive ocasião de dizer-lhe pessoalmente, creio que nossas diferenças decorrem muito mais do modo como compreendemos estes autores antigos e como nos interessamos pelos estudos de lógica, do que do modo como entendemos a filosofia de Espinosa. Parece-me que as afinidades que encontro entre Espinosa e, particularmente, a lógica aristotélica, vão mais longe do que gostaria Chauí. Eu evidentemente reconheço haver inegáveis e insuperáveis diferenças entre tais sistemas filosóficos (a contingência, a liberdade da deliberação, a multiplicidade substancial, a realidade do tempo, a distinção entre a física supra e sub lunar e tantas outras noções que têm lugar no aristotelismo mas não no espinosismo); não obstante, estimo que um mais demorado esforço na investigação de suas — não menos inegáveis - afinidades e continuidades, pode tanto beneficiar a exegese do texto espinosano quanto suscitar problemas interessantes e estimulantes sobre a própria história da filosofia. Não se deve, porém, supor, a partir do que digo aqui, que no livro de Chauí não haja aproximações e correlações entre Espinosa e Aristóteles. Muito pelo contrário! Todavia, como se pode perceber pelos resultados a que vai chegando esta introdução, eu valorizo as relações (inclusive genealógicas) entre Espinosa e o aristotelismo a partir da problemática lógico-ontológica da predicação, o que não se passa no Nervura do Real. Tanto melhor, pois, caso contrário, eu ficaria sem um argumento original. 
“toda a discussão sobre a 'combinação' ou 'mescla' das Formas é frequentemente chamada "lógica", e com certa razão; não obstante, é muito importante estabelecer em que sentido se pode dizer que Platão teve uma lógica e como ela difere da lógica tradicional que herdamos de Aristóteles (...) O professor Taylor sugere esta identificação e assinala (...) que 'A lógica é considera aqui [no Sofista], pela primeira vez na literatura filosófica, como uma ciência autônoma que se propõe a determinar os princípios supremos das proposições afirmativas e negativas (as combinações e separações)'. Ora, se o termo 'autônoma' significa que a dialética é uma lógica formal, que se ocupa das proposições e é independente da ontologia (...), esta afirmação me parece errônea"110

Ora, é claro que esta lógica platônica não se desvincula de uma ontologia. Mas, afinal, essa desvinculação também não ocorre na "lógica tradicional que herdamos de Aristóteles":

"para a delimitar os tipos básicos de operações que resultam em tipos diversos de predicação, Aristóteles não poderia ater-se a regras puramente lógicas que dissessem respeito apenas à coordenação entre os elementos linguiísticos nela envolvidos. Aristóteles precisa atentar também para a natureza das coisas a que se reporta a predicação, pois é em função dessa natureza que certos tipos de combinação serão admitidos ou afastados"111

\section{4) Remate: Espinosa parricida?}

Ao longo desta introdução, procurei apresentar o mapa, simultaneamente histórico e conceitual, dos temas lógicos e ontológicos através dos quais os interesses deste ensaio encontram seu percurso próprio até a teoria espinosana da definição. Vários elementos articuladores já foram efetivamente introduzidos; alguns, de modo patente, outros, à maneira de um sub-texto. Estes últimos serão explicitados ao longo dos capítulos subseqüentes, nos quais novos elementos, necessários a essa explicitação, também serão mobilizados. Todavia, desejo encerrar a presente introdução revelando, já aqui, certas articulações que me parecem suficientemente compreensíveis à luz da exposição pregressa. Para fazê-lo, recorro, então, à seguinte questão: é Espinosa um parricida? Terá razão Bayle, ao considerar que Espinosa, afirmando a existência de

\footnotetext{
${ }^{110}$ Cornford, F. Op. Cit. p 241

${ }^{111}$ Angioni, L. Op. Cit. Intro. P 25.
} 
modalidades reais no seio da substância única, destrói o princípio de não contradição? Ou terá razão Hegel, ao considerar que é o respeito clássico de Espinosa pelo princípio de não-contradição, associado à tese da unicidade substancial, que faz com que o conceito espinosano de substância permaneça refratário ao movimento, à particularidade e à determinação, como é próprio a uma filosofia não especulativa, distante da concretude, em suma, a uma "filosofia do entendimento"? Como já foi brevemente indicado nas seções pregressas, considero que tanto Bayle quanto Hegel estão simultaneamente certos e errados (mas, é claro, não no mesmo sentido).

Bayle percebe corretamente que os modos não podem ser reduzidos a meros epifenômenos da substância única e que, portanto, Espinosa não é um eleata castiço, como Parmênides, Zenão e Melisso, herdeiros de Xenófanes. Assim, embora sob a indevida acusação de contraditório, Espinosa é corretamente aproximado, pela leitura bayleana, dos suspeitos de parricídio. Todavia, acabamos de ver que, apesar da suspeita, a tradição platônico-aristotélica não cometeu efetivamente cometido, pois o que se recusou foi a divisão eleata entre ente e nada e o que se propôs não foi a contradição, mas sim a divisão do ente segundo o mesmo e o outro, como forma de solução do paradoxo lógico "do verdadeiro e do falso" e do correspondente paradoxo ontológico “do Um e do múltiplo". Ora, semelhante recusa é realizada por Espinosa, no capítulo I dos Cogitata Metaphysica, quando nosso filósofo, justamente para evitar dividir o ente em ente e não-ente, recusa dividi-lo em ente real e ente de razão e propõe que a divisão se dê - sempre no interior do ente real ${ }^{112}$ - entre substância e modo, ou seja, nos termos das definições 3 e 5 de Ethica I, entre o que é e se concebe em si e por si mesmo e o que é e se concebe em outro e por outro. Afastando-se de Parmênides e aproximando-se de Platão e Aristóteles, Espinosa realiza uma divisio no interior do ente real, introduz o modo como não sendo precisamente o que a substância é - a substância é em si e por si e o modo não - e o faz segundo a distinção entre o mesmo e o outro, ou seja, segundo a relação de alteridade e não segundo a de contrariedade. E essa alteridade não pode corresponder à mera distinção de razão se se quer que os modos sejam algo de real. Se Espinosa não deve ser um eleata, então, necessariamente, a alteridade

${ }^{112}$ Espinosa emprega o termo "não-ente" (non-ens), no contexto ora visado (Cogitata Metaphysica I, S.O 235, 5), como sinônimo de nada: "não fala menos ineptamente (nec minus inepte loquitur) quem diz que o ente de razão não é uma mero nada (non esse merum nibil)". Espinosa reconhece, em contrapartida, que, de um certo modo (aliquo modo), o ente de razão também pode ser dito um ente real, a saber, enquanto considerado como um modo de pensar, ou seja, como um puro evento mental, embora não reenvie a nada fora do pensamento. Isso, obviamente, testemunha a favor da operatividade da polissemia na noção de ente no interior do sistema espinosano. 
substância/modo, tal como opera em seu sistema, deve ser uma alteridade real, sem, contudo, ser uma distinção substancial.

E é por isso mesmo que, por outro lado, se vê em que medida Hegel tem alguma razão ao acentuar, contrariamente a Bayle, uma proximidade entre o sistema espinosano e o eleatismo, maior do que a que se pode verificar no caso dos outros pseudoparricidas: Espinosa não pode, por exemplo, apelar para a cláusula $c l$ da reformulação aristotélica do PNC (in eodem), pois, o que quer que seja (Quicquid est), em última instância, é em Deus (in Deo est) e se concebe através de Seu conceito (pela prop. 15 de Ethica 1). Ademais, Espinosa também não pode apelar para a cláusula $c 2$ (simul), pois, como ensinam os Cogitata Metaphysica, no mesmo Capítulo I acima mencionado, o tempo é um ente de razão, isto é, apenas um modo de pensar pelo qual explicamos comparativamente a duração das coisas. Se Aristóteles se afasta ao menos três passos do pai Parmênides — um passo para cada cláusula —, Espinosa afasta-se apenas um. Essa maior proximidade com o eleatismo foi bem percebida por Hegel, muito embora o filósofo alemão - suspeitando menos do que deveria do afastamento de Espinosa relativamente ao eleatismo - não tenha dado o devido peso à presença de $c 3$ no interior do sistema espinosano. Em resumo: a terceira cláusula do PNC é o passo pelo qual — mantendo-se num sistema da não-contradição - Espinosa toma distância do eleatismo, uma vez que, diferentemente de Aristóteles, já não pode mais apelar à multiplicidade de substâncias ou à separação entre instantes discretos no tempo, como formas de impedir a colisão de predicados incompatíveis no mesmo (c1) e ao mesmo tempo (c2).

Todavia, talvez não se queira conceder que a tese espinosana de que tudo "in Deo est' corresponda ao permanente atendimento de $c 1$, por receio de considerar a substância única como sujeito. Suponho que uma tal restrição poderia ser feita, por exemplo, por Macherey e por leituras que nele se inspiram, como, por exemplo, a de Gainza. Esses escrúpulos provêm do fato de que tais leituras pretendem salvar o sistema espinosano das acusações feitas por Bayle e por Hegel, propondo que Espinosa não trabalharia nos quadros do princípio de não-contradição justamente por livrar-se da noção de sujeito pressuposta por esse princípio. Espinosa não seria nem contraditório (como quer Bayle) nem não-contraditório (como quer Hegel) simplesmente porque estas duas censuras supõem - erroneamente, no entender de Macherey e Gainza - que a substância espinosana seja um subjectum. Recusa-se, então, a operatividade, no sistema espinosano, dessa que eu chamo de primeira cláusula do PNC. Considero, pois, que algumas 
precisões devem ser feitas. Concordo aqui, por exemplo, com Marilena Chauí e Lia Levy, quando afirmam, respectivamente, que:

“A chave da relação entre a substância única absolutamente infinita e suas infinitas modificações infinitas e finitas encontra-se na recusa espinosana de tratar a primeira como sujeito de inerência de predicados (ou como categoria) e de conceber os segundos como se fossem tais predicados. Essa chave e essa recusa são dadas, de um lado, pela passagem da concepção predicativa à concepção causal da relação entre substância e modos e, de outro, pelo emprego de dois verbos: envolver e exprimir. A substância envolve seus modos e estes a exprimem de maneira certa e determinada; ela os envolve porque são seus efeitos imanentes e é por isso que eles a exprimem." 113

“A definição de substância pela causa sui também coloca em questão o sentido da noção de sujeito passivo de modificações (subjectum inhaesionis). O modo é in alio, no sentido em que ele é na sua causa, pela qual ele se concebe, ou seja, uma coisa é modificação de uma outra somente se esta é causa daquela. Assim, ao menos do ponto de vista da substância, e na medida em que ela é causa imanente dos seus modos, não se pode jamais afirmar que ela é o sujeito de inerência de suas modificações, pois a substância não pode ser considerada como o simples suporte passivo de modificações"114

Os comentários são precisos: a substância não é subjectum se - e eu acrescentaria: somente se - a noção de subjectum for entendida fora de uma "concepção causal", ou seja, como um "simples suporte passivo", e se, de modo complementar, a noção de inhaesio for entendida sem qualquer referência às relações de envolvimento e expressão causais, ou seja, reduzida à relação de ser suportado por um sustentáculo extrínseco que meramente recebe isso que nele inere. Essas recusas, portanto, não correspondem à absoluta recusa da operatividade de quaisquer noções de "sujeito", de "inerência" e de "predicação" no sistema espinosano, recusa que simplesmente amputaria, negligenciaria ou menosprezaria - talvez sob pretexto de uma evolução cronológica no pensamento de Espinosa - inúmeras passagens textuais, nas quais essas noções comparecem de modo explícito. Menciono, pois, alguns exemplos:

(i) Veja-se, em primeiro lugar, a nota ao $\$ 8$ do primeiro capítulo da parte I da Korte Verhandeling, no contexto da prova a posteriori da existência de Deus, onde a noção

113 Chauí, M. Op. Cit. p 74. Negritos meus. (uso aqui negritos, e não itálicos, apenas para manter a simetria com a citação abaixo, que possui itálicos da própria autora)

${ }^{114}$ Levy, L. (1998) p 212; negritos meus, itálicos e incisos latinos da autora. 
de subjectum comparece inclusive aplicada a Deus. Essa prova consiste basicamente em mostrar - num argumento que lembra a prova a posteriori cartesiana - que a idéia de Deus não pode ser uma ficção da mente humana, devendo, finalmente, possuir o próprio Deus como sua causa extra mental. O homem pode criar ficções operando sobre uma primeira idéia - dividindo, separando, abstraindo e recombinando diversamente esses elementos - e também pode operar várias outras vezes sobre o resultado dessas mesmas operações. Mas, "o que Espinosa nega é a possibilidade de considerar como ficção também aquela primeira idéia sobre a qual se exercita a atividade ficcional da mente" $" 115$. É nesse contexto que a nota do $\$ 8$ introduz, em latim, o termo subjectum, para designar aquilo que possui formalmente o que a primeira idéia possui objetivamente: "[as idéias] devem possuir fora de mim um subjectum, que não sou eu, sem o qual subjectum não podem existir". E, num argumento a fortiori, Espinosa afirma que isso que se passa, direta ou indiretamente, com as idéias das demais coisas, também se passa com a idéia de Deus de tal modo que Ele não apenas "é o subjectum daquilo que eu afirmo (bevestig) dele", como também "deve ser o subjectum de todas as outras coisas". Assim, há um sentido em que Deus, sendo causa - causa da Sua idéia no homem e causa das demais coisas, cujas idéias também estão no homem —, não deixa de ser subjectum. Aliás, parece-me justamente que, se deixasse de sê-lo, não possuiria o preciso caráter de uma causa imanente, ou seja, daquela que não produz seus efeitos fora de si mas em (in) si mesma. Desde que esse "em" possa ser, de alguma forma, pensado em termos causais, Subjectum não será, pois, não uma incômoda palavra no vocabulário de Espinosa mas sim um conceito proativo de seus sistema.

(ii) E isso me parece se confirmar em uma segunda ocorrência do termo "sujeito" - agora em holandês (onderhouwder) —, no $\$ 9$ do Primeiro Diálogo, também na Korte Verhandeling. O diálogo traz como personagens Amor (Liefde), Intelecto (Verstand), Razão (Reede) e Concupiscência (Begeerlykheid). Os comentadores reconhecem, em geral, uma correspondência entre as três últimas personagens e os modos de percepção ou gêneros de conhecimento, que compõem o núcleo da teoria espinosana do conhecimento, a saber, segundo a terminologia adotada na Ethica, scientia intuitiva, ratio e imaginatio, respectivamente. Essa correlação não está livre de dificuldades mas, para o momento, pode ser aceita. De toda forma, em linhas gerais, a referência à teoria do conhecimento é, a bem dizer, inegável, visto que a personagem Amor, abrindo

\footnotetext{
${ }^{115}$ Mignini, F. (1986) p 433.
} 
o diálogo, afirma que sua própria perfeição depende das três outras personagens na exata medida em que elas concebem ou compreendem (begrepen) objetos (voorwerp). Amor, então, lhes pede que, enquanto são potências cognitivas, digam se conhecem um ser (wez̧en) sumamente perfeito (oppersten volmaakt), que não possa ser limitado (bepaald) por nenhum outro $^{116}$. À solicitação de Amor, Intelecto, correspondendo à scientia intuitiva, responde - numa breve e única fala — que vê ou contempla (aanschouw), como sendo o objeto solicitado, "a natureza (Natur) como um todo (als geheel)". Em seguida, confirmando Intelecto, Razão entra em cena argumentando demonstrativamente, a fim de provar que isso que foi visto ou contemplado é também indubitável (ontwyffelyk) quando submetido ao raciocínio. O argumento de Razão tem a forma de uma redução ao absurdo, ou seja, de um procedimento indireto, que confirma o que foi diretamente visto ou contemplado, ao demonstrar que o contrário disso não pode ser o caso. Tal argumento, organizado conforme o modus tollens, pode ser reconstruído da seguinte maneira:

(a) se $p$ (queremos limitar a natureza tomada como um todo) então $q$ (devemos limitá-la com o nada (Niet));

(b) ora, não $q$ (limitar a natureza com o nada é absurdo (ongerymt));

(c) $\log o$, não $p$ (a natureza tomada como um todo não é limitada ).

(d) Corolário: a natureza tomada como um todo deve ser, portanto, uma unidade (eenheid) infinita (oneiendig), eterna (eeuwidge), onipotente (almagtig), na qual (in de zelve) tudo está compreendido (alles begreepen);

(e) conclusão: era isso que Amor pedia.

Como é bem sabido ${ }^{117}$, o argumento de Razão retoma algumas passagens do

${ }^{116}$ É também de notar a semelhança entre o pedido de Amor e a inquirição que abre o Tractatus de Intellectus Emendatione, no $\$ 1$, qual seja, a inquirição por um bem verdadeiro que não fosse, em hipótese alguma, causa de infelicidade ou perdição, ou seja, por algo ilimitadamente bom. Nesse parágrafo também é dito que as coisas são boas ou más apenas com referência aos movimentos do animus, de sorte que este último, ou melhor, seus movimentos ou afetos, parecem ocupar no TIE o papel que Amor ocupa na KV. A isso também vem somar-se, nos $\S$ 9-10 do TIE, a mesma doutrina ora evocada por Amor na $\mathrm{KV}$ : "toda felicidade ou infelicidade consiste somente numa coisa, a saber, na qualidade do objeto ao qual aderimos por amor (tota felicitas, aut infelicitas in hoc solo sita est; videlicet, in qualitate objecti, cui adharemus amore)" (...) "o amor acerca de uma coisa eterna e infinita nutre o ânimo somente com felicidade, a qual é isenta de toda tristeza, o que é a desejar muito e a buscar com todas as forças (amor erga rem aternam, \& infinitam solâ latitiâ pascit animum, ipsaque omnis tristitia est expers; quod valdè est desiderandum, totisque viribus quarendum)"

117 Cf. Mignini, Atilano, Marilena 
capítulo imediatamente anterior da Korte Verbandeling - Capítulo 2 da Parte I, sobre o que Deus é $(W \text { at } G o d i s)^{118}$ —, principalmente a nota do $§ 1$. Esse parágrafo propõe que Deus seja "um ser do qual é dito (zeggen) tudo, a saber, infinitos atributos, cada um dos quais é infinitamente perfeito em seu gênero". A nota, então, explica que tudo que é dito ou afirmado é dito ou afirmado ${ }^{119}$ de Deus, porque:

"não podendo o Nada (Niet) ter (bebben) nenhum atributo (eigenschappen), o Tudo (Al) deve ter (moet bebben) todos (alle) os atributos. E, assim como o Nada não tem nenhum atributo, porque nada é (niet is), assim o Algo (Iet) tem atributos, porque é algo (iet is). Assim, tanto mais (hoe meer) o Algo é (Iet is), tanto mais atributos deve ter (boe meer eigenschappen moet hebben), e consequentemente, Deus, sendo perfeitíssimo, infinito, todos os algo (alle Iet), também deve ter todos os atributos, infinitos e perfeitos"

O Nada não pode limitar o Tudo simplesmente porque nada é: para realizar a função de limitar o Tudo, deveria fazer-lhe frente e, portanto, ser algo e ter atributos ${ }^{121}$. Ora, analogamente ao que procurei defender já a propósito da concepção parmenídica do ente, no início desta INTRODUÇÃo, não me parece possível negar, em face da contraposição com o nada, — caracterizado lá e aqui como nem sequer essente —, a presença de uma estrutura predicativa mínima na noção de ente, pressuposta também no

${ }^{118}$ É de notar que Mignini considera que a ordem seguida pela KV - qual seja, primeiro demonstrar que Deus existe e depois demonstrar o que ele é - segue a preceptiva aristotélica apresentada nos primeiros capítulos dos Analíticos Posteriores. Cf. Mignini, Op. Cit. p.

${ }^{119}$ Mignini e Dominguez traduzem zeggen por "afirmar", quando, no entanto, esse termo deve ser mais literalmente traduzido por "dizer", ao passo que o termo para "afirmar", tal como indicado mais acima, é bevestigen.

${ }^{120}$ Sigo aqui as traduções de Mignini e Atilano, fazendo, porém, uma mescla de ambas, quando, a partir da consulta ao léxico holandês, tal ou qual opção me pareceu mais literal ou mais clara ao ser vertida para o português. Sigo também a diferenciação entre maiúsculas e minúsculas, no início dos substantivos que protagonizam o texto (Niet, $A l$, Iet), tal como apresentada por Mignini em sua edição da $\mathrm{KV}$.

121 Julgo ser esse o sentido de um difícil texto na fala de Razão, que não incluí na citação anterior. Trata-se da passagem em que Espinosa parece dizer que, se o Nada limitasse a natureza, deveria ter os seguintes atributos: uno, eterno, por si, infinito. No manuscrito A, essa passagem está na margem do texto, anotada pelo copista, e no manuscrito B, está no corpo do texto. Freudenthal e Appuhn praticamente a eliminam, Gebhard, Mignini e Dominguez a mantém. Para que se tenha uma idéia do debate sobre o passo, reproduzo, aqui, algumas linhas da nota 25, que Mignini inclui na página 506 de sua edição da KV: "Freudenthal, observando no manuscrito duas correções de lacuna operadas pelo mesmo copista e não entendendo como ao nada se podem referir-se os atributos do ser, sustenta que o §3 [i.e. a referida fala de Razão] seja uma lição corrompida (...) Robinson considera como legítima a lição manuscrita, compreendendo que a atribuição das propriedades do ser ao Nada seja legítima em uma argumento por absurdo". Preferindo a posição de Robinson, restrinjo-me, porém, ao argumento da nota ao $\S 1$ do Cap. 2, e evito discutir tais ou quais atributos específicos, dizendo apenas que, se o Nada limitasse o Tudo, ele deveria, de alguma forma, "fazer-lhe frente" e, portanto, deveria ter alguma efetividade, sendo, por isso, algo e, assim, devendo possuir algum atributo (o que é absurdo). 
argumento espinosano aqui em pauta, visto que Espinosa afirma explicitamente que ser algo (iet) é ter algum atributo, ou seja, ser isto ou aquilo, possuir algum conteúdo em sua ação de ser. Mas, indo além do que se passa no eleatismo, os atributos espinosanos são, como se sabe, realidades da ordem do pensamento e da extensão, as quais, embora sejam distintas da substância apenas por uma distinção de razão, não são como os predicados puramente tautológicos do ente parmenídico, pois, embora tanto o conceito de pensamento quanto o de extensão impliquem o de substância, o conceito de pensamento não implica o de extensão e vice versa, ao passo que indivisível (oude diaireton estin) implica ingênito (agenehton) e imperecível (anwlethron), que implicam atual (nun estin), perfeito ou completo (teleion), consistente e contínuo (sunechés), sui generis (mounogenes) e único (hen $)^{122}$. Ademais, diferentemente do que se passa no poema de Parmênides - bem como na leitura eleata que Hegel faz de Espinosa — deve-se notar que, afora Nada, ainda resta uma outra diferenciação - interna, portanto, ao ente entre o Tudo e o Algo, diferenciação que prefigura a distinção entre substância e modo, que aparecerá mais ao final do capítulo 2. Com isso está de acordo Mignini, para quem, "nessa nota [Espinosa] assume a perspectiva parmenídica quanto à clara separação (netta separaz̧ione) entre o ser e o nada" ${ }^{123}$, sem que, não obstante, nosso filósofo apague, como faria um eleata, essa outra diferenciação interna: "no Tudo ainda se distinguem (si distinguono), como se verá em seguida, as modificações, que correspondem a isso que agora é chamado de 'algo",124. Ora, Razão conclui sua primeira fala dizendo que se chama de Nada a negação da unidade infinita, isto é, do Tudo. Logo, como ensinava Platão, a negação pela qual ser Algo não é o mesmo que ser Tudo (aqui caracterizada como distinção modal) não pode ser a mesma negação pela qual Nada não é Tudo e nem sequer Algo. Penso que estamos, pois, diante de uma transformação espinosana das clássicas relações entre o ente e o não-ente, de forma que o $A l$ é análogo, por exemplo, ao que em Platão é o totalmente ente (tò pantelós ón), o Niet é análogo ao nulamente ente (tò médamós ón) e o Iet é análogo ao outro, que é e não é... de certa maneira (katá ti).

${ }^{122}$ Como se pode notar, não faltam à substância espinosana essas características que pertencem ao ente parmenídico. A diferença, porém, encontra-se, por um lado, naquilo que a substância espinosana tem a mais do que o ente parmenídico e, por outro, na diferença do estatuto lógico e ontológico entre isso que é comum a ambos e isso que é exclusivo à substância: os atributos tautológicos do ente parmenídico pertencem à substância a título de própria, ao passo que pensamento e extensão é que recebem propriamente o título de atributos. A distinção entre atributos e própria é essencial para este ensaio e será retomada em capítulo futuro.

${ }^{123}$ Mignini, Op. Cit. p 467

${ }^{124}$ Mignini, Op. Cit. p 468. Itálicos meus. 
Não há novidade no reconhecimento de influências platônicas, aristotélicas e neo-platônicas sobre a Korte Verbandeling ${ }^{125}$. Mas tampouco se deve desconsiderar, a propósito do tema em pauta, a influência do artigo 52 da Parte I dos Principia Philosophiae de Descartes ${ }^{126}$, no qual se diz ser uma "noção comum" o fato de que "do nada não há atributos" (nibili nulla sint attributa), isto é, quaisquer propriedades ou qualidades (nullaeve proprietas aut qualitates)"; donde vem que, se há algum atributo, necessariamente deve haver alguma coisa ou substância (aliquam rem sive substantia) à qual isso possa ser atribuído (cui alliud tribui possit), ou seja, algo que desempenhe o papel de proprietário da propriedade ou de qualificado pela qualidade (por outras palavras: o papel de subjectum). Outro texto cartesiano que também é devido lembrar é o Axioma 6 das Rationes, onde se manifesta a doutrina dos graus de realidade ou entidade, segundo a qual a substância tem mais realidade do que o acidente ou o modo, e a substância infinita mais do que a finita. Assim, se há algum ente, por menor que seja seu grau de realidade, ele deve possuir, em igual medida, algum atributo, propriedade ou qualidade (por outras palavras: algum predicado). Todavia, apesar das evidentes afinidades entre os textos cartesianos e espinosanos ora evocados, é de notar, por fim, que algo deve ter sido alterado por Espinosa na concepção da estrutura predicativa mínima, segundo a qual, para os dois autores, não ser o nada (ser ente) já ser sujeito de predicados e ser sujeito de predicados já é ser algo (ser ente) e não nada. O sintoma mais significativo dessa mudança é que, para Descartes, como se lê no artigo 53 dos Principia,

“certamente, é a partir de qualquer atributo (ex quolibet attributo), que uma substância é conhecida, mas é uma só, no entanto (sed una tamen), a propriedade principal (praecipua proprietas) de cada substância, a qual constitui a natureza e a essência da mesma e à qual todas as outras [propriedades] são referidas. A saber, a extensão em comprimento, largura e profundidade constitui a natureza da substância corpórea, e o pensamento constitui a natureza da substância pensante. Pois tudo o mais (omne aliud) que pode ser atribuído (tribui) ao corpo pressupõe a extensão e é apenas um modo (tantum modus quidam) da coisa extensa; assim como todas as coisas que encontramos na mente são apenas

${ }^{125}$ Veja-se, por exemplo, os artigos: "De las Maravillas acerca de lo uno y lo multiple - O sobre los avatares del amor neoplatonico en la Korte Verhandelingde Baruch de Espinosa" de G. Albiac, e "La presenza di Aristotele nella Korte Verhandeling” de F. Chiereghin, ambos em Mignini, F. (Org.) 1990, respectivamente nas páginas 415-442 e 443-456.

${ }^{126}$ Uso como base para as citações dos Principia Philosophiae, a edição bilíngüe que contém a tradução coletiva, coordenada por Guido Antônio de Almeida: Descartes, R. Princípios da Filosofia. Rio de Janeiro, Editora UFRJ, 2002. Realizo, porém, algumas alterações pontuais, de pouca monta, apenas a fim de facilitar a inserção dos sintagmas latinos no interior da tradução em português. 
diversos modos (tantum diversi modi) de pensar"

Diferentemente, para Espinosa, como se lê no já referido primeiro parágrafo do Capítulo 2 da Korte Verhandeling, Deus é um único ser, dotado, não obstante, de infinitos atributos, dentre os quais, pensamento e extensão. Mas, como isso é possível se conforme dito mais acima e guardando algo da noção cartesiana de propriedade principal - pensamento e extensão podem ser entendidos clara e distintamente, um sem o outro? Ora, é exatamente com esta interrogação que, no Primeiro Diálogo, entra em cena a personagem Concupiscência, pretendendo apontar contradições no que Intelecto contemplara e Razão demonstrara, a fim de aconselhar Amor a não buscar, para além da multiplicidade dispersa, esse Tudo fora do qual não há coisa alguma. Concupiscência, exprimindo-se numa linguagem de coloração platônica ou neo-platônica, apresenta quatro argumentos, dos quais o primeiro, de matriz cartesiana, corresponde ao ponto ora mencionado, exigindo de Razão a superação da tese de que é um só o atributo principal de cada substância, como o pensamento o é da mente e a extensão é do corpo:

"Concupiscência: — Um momento! Sonha admiravelmente que, com a multiplicidade (Verscheidentheit) que vejo por toda parte na natureza, convenha a unidade (Eenheit). Mas, como? Vejo que a substância pensante não tem nada em comum com a substância extensa e que uma limita a outra"

No parágrafo 17 do mesmo capítulo, Espinosa apresenta três razões pelas quais se deve dizer que todos os atributos que existem na natureza não são substâncias distintas mas pertencem a um ser único, ainda que possam ser entendidos clara e distintamente um sem o outro. Concentremo-nos na primeira razão, pois ela se baseia fundamentalmente na regra, antecipada pela nota do $\S 1$, que estabelece a razão direta entre os graus de realidade e a quantidade de atributos. Tal como eu o entendo, o argumento consiste em reconhecer que, de uma parte, a regra de proporção colapsaria se uma de suas instâncias fundamentais, a saber, a realidade infinita, fosse acompanhada de substâncias separadas, já que, sendo Algo (Iet), essas substâncias teriam atributos e, sendo separadas, seus atributos não pertenceriam à mesma coisa, produzindo a absurda situação em que a realidade infinita, ao lado dessas substâncias, não possuiria os atributos delas e, portanto, não possuiria todos. Mas, de outra parte, a posse de todos os atributos por esse Tudo $(A l)$ não pode tampouco significar a perda do atributo que qualquer Algo sempre tem: seria tão absurdo quanto propor um Tudo que não tivesse 
todos os atributos, propor um algo que não tivesse algum (o que produziria um esvaziamento ontológico de toda multiplicidade, de feição eleata). Isso exige que os atributos, que cada Algo (Iet) tem, sejam, em última instância, também e ao mesmo tempo atributos de um só ser. Ora, a forma que Espinosa encontra para atender a essa exigência é propor que cada Algo, sem perder seu atributo, esteja de alguma forma contido nesse ser total, pois, caso contrario, a posse de todos os atributos pelo grau infinito de realidade seria a absurda perda do atributo que a regra prevê para o seu grau primeiro. O "ser em" é pois, a relação que preserva a primeira e a última instancia da regra de proporção, o múltiplo particular (Iet) e o uno total $(A l)$, evitando que a última instância roube o atributo da primeira, num esvaziamento eleata, e que a primeira fragmente a segunda, numa multiplicidade substancial cartesiana. E é isso o que, no $\$ 9$ do Primeiro Diálogo, Razão responde a Concupiscência através da noção de sujeito. 


\section{CAPÍTULO I}

\section{Caracterização do Tractatus de Intellectus Emendatione como uma lógica e uma Medicina Mentis, simultaneamente contraposta e tributária \\ da tradição aristotélica.}

\section{1) SOBRE A LEGITIMIDADE DA ARTICULAÇÃo ENTRE O DE EMENDATIONE E A TRADIÇÃO} ARISTOTÉLICA: CONTINUIDADE E RUPTURA.

Ao adotar uma estratégia semelhante para investigar, por exemplo, a teoria cartesiana da ciência proposta nas Regulae, admitindo relações subjacentes dessa obra com o saber aristotélico, Jean-Luc Marion ${ }^{127}$ viu-se naturalmente obrigado a justificar tal procedimento, uma vez que Descartes sempre foi explícito ao caracterizar sua própria filosofia como oposta ao saber dos antigos e à ortodoxia da escolástica. Mas, revertendo a dificuldade, o comentador pôde fazer dessa oposição explícita o princípio mesmo da justificativa que lhe era exigida, pois que o contraste entre a pretendida clareza da ciência cartesiana e a suposta obscuridade de que esta última acusava a tradição, conquanto ofuscasse a faixa cinzenta das articulações entre ambas, não poderia apagar o fato, tanto histórico quanto lógico, de que só os pensamentos que possuem algo em comum podem ser opostos, ou seriam, caso contrário, reciprocamente indiferentes:

"ao encontrar, a cada momento do percurso completo da teoria aristotélica da ciência, e dos seus fundamentos ontológicos, os conceitos inevitáveis que ele contradiz, Descartes não se limita justamente a contradize-los; neste caso, na verdade, ele continuaria tributário dos mesmos, dado que se limitaria a inverte-los. Pelo contrário, traduz seu significado no seu novo universo conceitual: mantêm-se as relações entre o intuitus e o 'atingir pelo pensamento', entre os princípios e a dedução; mas a dedução torna-se série, os princípios, naturezas simples, o atingir, visão por evidência do claro e distinto. Cada conceito sofre então uma múltipla deslocação e reorganização, que mede seu desvio" "128

127 Marion, J-L. Sobre a ontologia cinzenta de Descartes - Ciência cartesiana e saber aristotélico nas Regulae. Instituto Piaget, Lisboa, 1990.

${ }^{128}$ Idem Ibidem, p. 32. 


\section{(1.1.1) O Programa Cartesiano De Comparação Com A Escolástica e Os Cogitata} Metaphysica De Espinosa.

Mas, diante da proposta de adotar aqui uma semelhante abordagem de Espinosa, poderia alguém assim objetar: as considerações de Marion referem-se especificamente a Descartes e, mais ainda, a Descartes lido principalmente através de uma obra muito peculiar, as Regulae, que - por sua conturbada genealogia, sua posteridade obscurecida pelo cartesianismo consagrado, suas vicissitudes no âmbito do estabelecimento do texto, sem mencionar suas dificuldades propriamente conceituais - autorizam que o intérprete busque outros pontos de referência ou clarificação fora do texto cartesiano ${ }^{129}$. Seria igualmente lícito pretender reexaminar a teoria espinosana da definição, apresentada sobretudo no Tractatus de Intellectus Emendatione, à luz de temas platônicos e aristotélicos trazidos a nosso filósofo — crítico desta tradição — via Escolástica tardia?

Não tenho, com efeito, qualquer intenção de adentrar nas Regulae ou em seu exame detalhado por Marion. Os menciono, contudo, porque, se essa obra de Descartes, como quer o comentador, puder ser considerada como o esboço de uma sempre prometida "comparação da filosofia que se ensina nas vossas escolas (da Companhia de Jesus) com a que eu (Descartes) publiquei”"130, isso, então, contribuirá para licitar a presente estratégia, uma vez que o único livro publicado em vida por Espinosa sob seu nome ${ }^{131}$ foi justamente uma reconstrução geométrica dos princípios da filosofia cartesiana (Renati Descartes Principiorum Philosophic), apendiceada por um texto que empreende nada menos que esse mesmo programa de comparação que o próprio Descartes jamais publicou: os Cogitata Metaphysica. Ou seja, esse Appendix espinosano pode ser entendido como uma versão patente daquilo que Marion considerou ser o intuito latente das Regulae cartesianas ${ }^{132}$. E se é lícita alguma articulação da ciência

${ }^{129}$ Idem Ibidem, p. 24-27.

${ }^{130}$ Descartes a R-P Chasles, Dezembro de 1641, apud Marion, Op. Cit. Supra, p. 30. Na mesma passagem, Marion reúne outras declarações de Descartes de semelhante teor, tais como: "E o meu objetivo é escrever ordenadamente todo um curso de filosofia sob a forma de teses, no qual, sem nenhuma superfluidade de discurso, eu incluiria unicamente todas as minhas conclusões com as verdadeiras razões de onde as tiro, o que julgo poder fazer com poucas palavras; e imprimir no mesmo livro um curso de filosofia ordinária, talvez como o de frei Eustáquio (...) e talvez faça uma comparação entre estas duas" (Carta de Descartes a Mersenne, 11-11-1640); "Começo por fazer (da minha filosofia) um resumo em que ordenarei todo o curso, para que seja impresso com uma síntese da filosofia da Escola (...) o que julgo poder fazer de modo que se veja facilmente a comparação de uma com a outra" (Carta de Descartes a Mersenne, ?-12-1640).

${ }^{131}$ O Tractatus Theologico-Politicus foi publicado anônimo, muito embora a autoria espinosana tenha sido rapidamente reconhecida e divulgada (principalmente para ser atacada).

${ }^{132}$ Sugestão semelhante — acerca dos Cogitata e não das Regulae — foi feita por Daniel Garber. 
cartesiana com o saber aristotélico a partir do que é latente, então será lícita a fortiori uma articulação semelhante a partir do que em Espinosa é patente. Mais simples ainda: ao incluir um exame crítico do aristotelismo da Escola em seu livro sobre Descartes, Espinosa exprime o fato de que, para um leitor da época, mais do que lícito, era relevante e proveitoso expor a constituição polêmica da modernidade cartesiana no debate filosófico com o pensamento metafísico aristotélico. Tomar esse debate como referência não é, portanto, no presente ensaio, apenas uma estratégia historicamente válida, ou seja, não anacrônica, mas sobretudo a retomada de uma operação intertextual já realizada pelo próprio Espinosa.

\section{(1.1.2) Aproximação Direta de Espinosa Com A Escolástica.}

Todavia - nova objeção —, o diálogo de Espinosa com o aristotelismo escolástico não poderia permanecer restrito ao âmbito desse seu trabalho como comentador de Descartes? Seria lícito avizinhar desse mesmo contexto assumidamente cartesiano as obras de auto-apresentação direta da filosofia espinosana?

Ora, em primeiro lugar, a reconstrução geométrica que Espinosa faz dos princípios da filosofia cartesiana nos $P P C$ não deixa de ser, avant la lettre, uma sorte de "crítica imanente" ou "crítica pela apresentação" do cartesianismo, uma vez que se propõe não só a comentar os Principia — o livro — de Descartes, mas também a demonstrar os princípios dessa filosofia, reorganizando-os em uma nova ordem ${ }^{133}$. Assim, embora os PPC e os Cogitata possam ser postos sob a rubrica do comentário, tais obras são, não obstante, legitimas expressões da filosofia de Espinosa, detentoras da particular qualidade de expressarem a interpenetração constitutiva que nelas o autor estabelece entre filosofia e história da filosofia. E em segundo lugar, conquanto os Cogitata possam ser entendidos como uma versão, levada a cabo e publicada por Espinosa, de um projeto comparativo originalmente cartesiano, não é certo, porém, que as fontes que constituem a tradição metafísica visada por Espinosa sejam exatamente as mesmas originalmente visadas por Descartes. Ora, isso significa que as referências de Espinosa a certa tradição metafísica são fruto de sua própria formação e pesquisa.

No panorama dos estudos acadêmicos sobre Espinosa durante os últimos cento e quarenta anos, o atual estado da questão conduz a afirmar que somente o

${ }^{133}$ Veja-se a nota de Marilena Chauí ao titulo de sua tradução dos Pensamentos Metafísicos, no volume dedicado a Espinosa da coleção "Os Pensadores". Abril Cultural, 2 ${ }^{\mathrm{a}}$. Ed. 1979. Veja-se também, quanto à originalidade que preside o trabalho de Espinosa nos PPC, Santiago (2004). 
desconhecimento ou uma atitude que, a qualquer preço, partidarize a historia da filosofia e a simplifique em caricatas dicotomias, poderia recusar a presença de um diálogo com a escolástica na constituição da filosofia espinosana. Já em 1867, F. A. Trendelenburg $^{134}$ chamava atenção para duas menções diretas que Espinosa faz ao escolástico holandês Adriaan Heereboord: uma nos CM II, 12, sobre a liberdade humana, outra na $K V$ I, 3, sobre as divisões da causa eficiente (esta última, como veremos, decisiva no presente ensaio). Mas foi em 1887 que J. Freudenthal, empreendendo um cuidadoso cotejo dos Cogitata e de Ethica I com obras de escolásticos tardios (Suarez, Clauberg, Burgersdijk, Heereboord, entre outros), produziu o ainda hoje influente Spinoza und die Scholastik ${ }^{135}$, no qual o autor mostra que certas frases do texto espinosano podem ser reencontradas, quase ipsis literis, nessa bibliografia presente no acervo pessoal de nosso filósofo (quando não, nas instituições de ensino da Holanda seiscentista), desvelando uma firme camada de referências, muito mais rica e intrincada do que aquela das menções diretas ${ }^{136}$. É verdade que essas frases são muitas vezes acompanhadas da indicação de uma autoria alheia mas não nomeada (e.g.: authores, quidem, etc.), e que, na maioria dos casos, são introduzidas por Espinosa como objeto de crítica; mas isso não impede que, a partir delas, Freudenthal reconheça um reaproveitamento do que está sendo criticado, de forma que um novo uso espinosano desses conceitos se organize justamente através do afastamento relativo ao ponto de partida. A pesquisa iniciada por Freudenthal no final do século XIX inaugurou, assim, uma linha de trabalho que - intencionalmente empenhada em ampliar seus resultados iniciais ou apenas deles se beneficiando de modo independente ou indireto - perpassa a produção acadêmica sobre Espinosa ao longo de todo o último século até chegar ao corrente $^{137}$.

${ }^{134}$ Trendelemburg, F .A. Ueber die aufgefundenen Ergäzungen zu Spinozas Werken und deren Ertag für Spinozas Leben und Lehre, 'Hist. Beitr. zu Philos.', III, 1867. Refiro-me a Trendelemburg de segunda mão, seguindo o resumo do estado da questão feito por Dominguez, A(1997) .

${ }^{135}$ Freudenthal, J. "Spinoza und die Scholastik" in: Philosophische Aufsätze: Eduard Zeller zu seinem fünfzigjährigen Doctor-Jubiläum gewidmet (Leipzig, 1887). Cito Freudenthal de segunda mão, seguindo Coppens, G. "Spinoza's Renati des Cartes Principiorum Philosophiae and Cogitata Metaphysica" in Geschiedenis van de wijsbegeerte in Nederland, 12, 2003-2004, disponível em: http://spinoza.mine.nu/Microsoft\%20Word\%20-\%20Russia.html.pdf G., referido na nota anterior.

Veja-se um apanhado sumario dos apontamentos de Freudenthal no artigo de Coppens,

137 Isso pode ser conferido através do levantamento condensado feito por Atliano Domínguez em seu já citado artigo, ao qual fiz aqui alguns acréscimos: j. Lewkowitz (Spinoza's Cogitata Metaphysica und ihr Verhaeltnis zu Descartes und zur Scholastik 1902); Richter (Spinozas philosophische Terminologie 1913); H. A. Wolfson (The Philosophy of Spinoza 1934); P. Di Vona (Studi sull'ontologia di Spinoza 2vols. 1960 e 1969; Spinoza e i transcendentali 1977; Los términos transcendentales en Spinoza y en los escolásticos de su tiempo, 1978); M. Gueroult (Spinoza 2vols. 1968 e 1974); H. De Djin 


\section{(1.1.3) O De Emendatione Como A Contraparte Positiva Dos Cogitata Metaphysica.}

Entretanto - insistiria o objetor —, isto ainda é muito vago e periga por soar como um argumento de autoridade. Será, afinal, lícito e interpretativamente vantajoso avizinhar, em específico, o Tractatus de Intellectus Emendatione e esse contexto de discussão aristotélica? Ora, deve-se novamente responder que sim, agora a partir do próprio subtítulo explicativo adicionado por Pieter Balling — com a chancela de Espinosa - à primeira parte da versão holandesa dos Cogitata Metaphysica, de 1664:

"O fim e o objetivo desta parte é mostrar que a Lógica (Redenkonst $=$ lit. 'arte de raciocinar' ou 'arte da Razão') e a Filosofia comuns só servem para exercitar (oeffenen) e fortalecer (versterken) a memória (geheugenis), a fim de que recordemos bem as coisas que se nos mostram a cada passo, sem ordem nem conexão (en zonder orde of t'zamenhangin), através dos sentidos (zinnen) e que, por isso mesmo, só afetam nossos sentidos mas não servem para exercitar o intelecto (verstant)"

Verifica-se, destarte, nesse apêndice - dedicado a explicar brevemente as questões mais difíceis da Metafísica Geral (que trata do ente enquanto ente e das afecções que possui enquanto tal) e da Metafísica especial (que trata de dois entes em específico: Deus e seus atributos, e a mente humana) ${ }^{138}$ —, a intenção de uma crítica especialmente voltada para a lógica de inspiração aristotélica aí tradicionalmente empregada $^{139}$. E essa crítica diz respeito ao próprio cerne do De Emendatione, qual seja, as relações entre a imaginação (instanciada aqui pelos sentidos, żinnen, e pela memória, gehengenis), a razão (Reden, sintomaticamente associada, aqui como na Korte

(Historical Remarks on Spinoza's Theory of Definition in JG van der Bend, ed., Spinoza on Knowing, Being and Freedom 1974); F. Biasutti (La dottrina della scienza in Spinoza 1979); A. Dominguez (além do artigo de 1997: a tradução dos Cogitata Metaphysica para o espanhol, acompanhada de uma Introdução e 44 notas sobre Espinosa e Suarez, 1988); F. Chiereghin (La presenza di Aristotele nella Korte Verhandeling di Spinoza, in F. Mignini Org. Dio, L’Uomo, La Liberta 1990); M. Chauí (A Nervura do Real 1999); A. Garrett (Meaning in Spinoza's Method, 2003); H. Santiago (Espinosa e o cartesianismo - O estabelecimento da ordem nos Princípios de Filosofia Cartesiana 2004); Gunther Coppens (Spinoza en de scholastiek, 2003; Spinoza's Renati des Cartes Principiorum Philosophiae and Cogitata Metaphysica, 2004).

138 Trata-se aqui do subtítulo latino dos Pensamentos Metafísicos: "Cogitata Metaphysica, In quibus Difficiliores, qua in Metaphysices tam parte Generali, quam Speciali, circa Ens, ejusque Affectiones, Deum ejusque Attributa, \& Mentem humanam occurrunt, quastiones breviter explicantur'. S.O. I, 233, 1.1-7

139 É de notar que a crítica à lógica é apontada como sendo o conteúdo da primeira parte dos Cogitata, ou seja, da parte que trata da Metafísica Geral, que diz respeito ao ens. Isto será retomado no CAPÍTULO ; quando a noção de ente for explorada em um registro simultaneamente lógico e ontológico, isto é, ao mesmo tempo como estrutura na qual se encontram compostos os elementos de uma predicação e como unidade real complexa de articulações causais internas e externas a si mesma. Esta é a nota nb. 
Verhandeling ${ }^{140}$, ao termo Kunst ${ }^{141}$, formando a palavra que se traduz por lógica) e o intelecto (Verstant, denominação holandesa que também facilitará posteriores considerações históricas no debate com a tradição alemã). Os Cogitata, portanto, acusam e pretendem demonstrar que a lógica escolástica não faz precisamente aquilo a que o $D e$ Emendatione se propõe: determinar um modo de exercitar (oeffenen) e fortalecer (versterken) o intelecto ou, nos termos do De Emendatione, "tratar (medendi) ${ }^{142}$ e purificar (expurgandi) o intelecto para que intelija as coisas otimamente, sem erro e com felicidade"143, ou ainda, "emendar (emendandum) o intelecto e refazê-lo apto (aptum reddendum) a inteligir as coisas do modo necessário à consecução de nosso fim"144, fim este que não é senão fruir — individual e socialmente ${ }^{145}$ — de uma "bumanam naturam" mais firme (firmiorem) e perfeita $^{146}$. Veja-se também o subtítulo holandês do De Emendatione, no qual se diz que o tratado versa acerca "do meio pelo qual o intelecto é tornado perfeito"147. E acrescentese a isso o que ensina o prefácio da Parte $V$ da Ethica, a saber, que "a maneira e a via pela qual o intelecto é aperfeiçoado (perfici) diz respeito à lógica"148, assim como "a arte pela qual o corpo é cuidado (sit curandum) ${ }^{149}$ para que possa funcionar retamente em seu ofício (suo officio recte fungi) diz respeito à medicina" ${ }^{\prime 50}$.

\section{Remate de 1.1}

Portanto, através dessas articulações, faz-se plenamente lícito pretender

$\begin{array}{ll}140 & \text { Cf. KV II, 3: “Kunst van Reden” } \\ 141 & \text { Correlato do latim ars e do grego techné. } \\ 142 & \text { É possível traduzir medendi por medicar, uma vez que este termo em português também }\end{array}$
comporta o sentido geral de dar tratamento. Todavia, o Latim dispõe dos verbos medico e medicor, e não foram eles os adotados por Espinosa nesta passagem. Adotei, portanto, a idéia de tratar, pois isso conserva a evocação médica mas sob a idéia mais ampla de "ocupar-se de". optimè intelligat'

TIE §16: "medendi intellectûs, ipsumque (...) expurgandi, ut feliciter res absque errore, \& quàm

TIE $\$ 18$ "emenda[re] intellectum, eumque aptum redde[ere] ad res tali modo intelligendas, quo opus est, ut nostrum finem assequamur"

145 TEI $\$$.

146 Cf. TIE $\$ 12$ "homo concipiat naturam aliquam bumanam suâ multò firmiorem, ¿o simul nibil obstare videat, quominùs talem naturam acquirat, incitatur ad media quarendum, qua ipsum ad talem ducant perfectionem".

147 "En te gelijk van de Middel om het zelfd volmaakt te maken". Subtítulo presente em De Nagelate Schriften; tradução de H.J. Glazemaker em 1678.

148 "Quomodo (...) et qua via debeat intellectus perfici (...) ad logicam spectat".

149 É possível traduzir "sit curandum" por "seja curado". Todavia, esse é um sentido secundário, derivado da situação mais ampla de "receber cuidado", como quando se diz que algo está à cura de alguém, este último sendo, portanto, curator, ou seja, curador (encarregado de, com conotação politica, por exemplo). As motivações desta nota, bem como da nota sobre medendi ficarão plenamente explicadas no Capítulo II, p.

150 "arte corpus sit curandum ut possit suo officio recte fungi (...) ad medicinam spectat"; ibidem. 
avizinhar o De Emendatione de certo contexto de debate com a lógica e a metafísica de inspiração aristotélica que alcançam Espinosa, quer via Descartes, quer via escolástica tardia. Pode-se duvidar, contra Marion, que as Regulae sejam o esboço da pretendida comparação crítica de Descartes com o aristotelismo escolástico; mas não se pode negar que os Cogitata, apendiceando os $P P C$, atendam perfeitamente a esse programa, só que agora comparando o cartesianismo reconstruído por Espinosa e uma tradição lógicoontológica diretamente estudada por nosso filósofo. Desta última, o tratado faz-se então tributário, ainda que por meio de um processo transformador de reaproveitamento polêmico dos conceitos. Na condição de uma Medicina Mentis - porque se propõe a tratar, purificar, exercitar, fortalecer e aperfeiçoar o intelecto -, o De Emendatione pode então ser compreendido como a contrapartida positiva dessa crítica de Espinosa à lógica escolástica, o que é interpretativamente vantajoso, pois contribui para o entendimento da própria situação do De Emendatione no interior do sistema espinosano, qual seja, a de uma lógica. Essa lógica encontra-se votada a curar, ou melhor, - na acepção latina ampla de curo, curare -, a cuidar da mente, zelando pelo reto funcionamento de seus ofícios. Tais ofícios - ensina a doutrina espinosana dos modos de perceber ou gêneros de conhecimento ${ }^{151}$ - consistem basicamente em ter idéias das afecções corporais, raciocinar e inteligir. E nas condições presididas por uma verdadeira lógica, esses ofícios serão efetuados livremente, isto é, sem que se confundam e bloqueiem entre si, como se depreende do fato de que a primeira parte do método consiste justamente em discerni-los, para que possam desempenhar todo o poder de que são naturalmente capazes. Nessas condições, as idéias se organizam segundo uma lógica que Espinosa estima ser diferente da que era tradicionalmente empregada pela Escola, implicando alterações, por exemplo, na formação de conceitos tais como os de ente (na metafísica geral) ${ }^{152}$, de Deus e seus atributos e de alma (na metafísica especial).

\section{2) O DE Emendatione Como Lógica e Medicina Mentis}

Mas — poder-se-ia perguntar —, falar aqui da lógica como Medicina Mentis não seria levar longe demais o que não passa de uma figura de linguagem, uma comparação puramente retórica e feita en passant entre o funcionamento (officio fungi) do corpo - a

151 Comentarei mais diretamente essa teoria no capítulo

152 Sobretudo a parte um é visada pela nota da edição de Balling. Mas, uma vez que a parte 2, sobre Deus e a alma, depende da parte 1, pode-se estender Veja-se Nota nb 
fisiologia, talvez disséssemos hoje - e o funcionamento do pensar? Ora, uma resposta negativa pode ser dada com base em vários antecedentes históricos, bem como a partir de articulações conceituais presentes nos textos espinosanos. E ao ser apresentada essa resposta, também ficará mais claro o sentido em que as atividades de curar, purificar, exercitar, fortalecer e aperfeiçoar o intelecto devem ser entendidas como afazeres lógicos.

\section{(1.2.1) Antecedentes Históricos Da Articulação Entre Lógica E Medicina No De} Emendatione.

É Marilena Chauí quem fornece um dos mais completos levantamentos históricos acerca das influências da tradição médica sobre o De Emendatione ${ }^{153}$. Evidentemente, não é necessário repetir aqui o que, então, já se encontra feito. Limitome, pois, a inventariar e apresentar de modo sumário o conjunto de matrizes levantadas pela comentadora, eventualmente complementando-as com algumas outras fontes mas, principalmente, sublinhando em cada caso os aspectos que me parecem melhor elucidar a relação entre Medicina Mentis e Lógica, segundo meus próprios interesses.

\section{(a) - A medicina antiga.}

Adotando uma sequiência cronológica, começo por indicar a influência da tradição médica grega, cujas matrizes principais são o Corpus Hippocraticum e as obras de Galeno $^{154}$. Tal indicação pode, no entanto, despertar alguma resistência, pois corre o risco soar como algo inócuo, porque é recurso banal remeter não importa o que na história da filosofia e da medicina às suas veneráveis origens gregas. Mas essas

153 Cf. Chauí, M. Nervura do Real, todo o Capítulo 5, mas sobretudo sua seção 1, c (Engenho e Arte), pp. 663-670.

154 É preferível falar em Corpus Hippocraticum (constituído por 72 livros) ao invés de falar diretamente de Hipócrates, em razão das controvérsias acerca da autoria desse material. Esse Corpus constitui, ao que parece, uma das mais antigas coleções de manuscritos científicos do mundo grego, "os mais antigos datados do período entre a segunda metade do século V e a primeira metade do século IV a.C., e os mais recentes, no período Helenístico e Romano. Segundo os principais comentadores e estudiosos da medicina antiga, parte da coleção já se encontrava na biblioteca da escola dos Asclepíades da Ilha de Cós, provavelmente produzida e reunida por seus integrantes e pelo próprio Hipócrates de Cós (460-380 a.C.)" Rebollo, Regina A. (2003) p. 275-97; p. 276. "O Corpus Hippocraticum ganha suas duas primeiras edições [no primeiro século de nossa era]: a de Artemidoro (I d.C.) e a de Dioscórides (I d.C.), hoje infelizmente perdidas, mas que um século mais tarde foram utilizadas e comentadas por Galeno. (...) Galeno (II d.C.) foi, sem dúvida, o principal comentador e exegeta de Hipócrates e do Corpus Hippocraticum. (...) Na obra Sobre os meus livros, Galeno cataloga sua obra geral classificando-a e rubricando-a. Na sexta rubrica, “Comentários a Hipócrates", Galeno descreve os manuscritos hipocráticos por ele analisados. Seguindo a tradição filológica e exegética de Alexandria, Galeno recopia os textos de Hipócrates expondo a doutrina médica ali contida, comentando-os e explicando as passagens mais difíceis” Rebollo Op. Cit. p. 289. 
resistências podem ser facilmente dissipadas tão logo seja notado o papel fundamental que uma mesma temática desempenha tanto na remota medicina grega quanto no Corpus Espinosanum, nas imediações conceituais do próprio De Emendatione. Trata-se da clássica temática da relação entre arte e acaso.

Com efeito, na Carta 37, Espinosa transcreve a seguinte pergunta, que seu amigo — o médico Bouwmeester — lhe havia feito em missiva hoje perdida:

"Há ou pode haver um método tal que por ele possamos chegar, com passo desimpedido e sem fadiga, ao pensamento das coisas mais importantes? $\mathrm{Ou}$, na verdade, do mesmo modo que nossos corpos, também assim nossas mentes são assujeitadas pelo acaso (casibus obnoxice sint) e nossos pensamentos mais pela fortuna do que pela arte são regidos? (\& fortunâ magis, quàm arte cogitationes nostra regantur?)" ${ }^{\prime 155}$

A resposta de Espinosa afirma (i) que há, sim, um método pelo qual podemos dirigir e concatenar (dirigere et concatenare) nossas percepções claras e distintas; (ii) que nosso intelecto não está, como o corpo, assujeitado pelo acaso (intellectus non sit veluti corpus, casibus obnoxius); (iii) que a fortuna, na verdade, não são senão causas que agem segundo leis fixas e determinadas (fortun [a], hoc est, caus[ae] certis etiam, \& fixis legibus agentibus), mas que se nos afiguram como Fortuna porque as ignoramos e porque são alheias a nossa natureza e potência (nobis tamen ignotis, \& à nostrâ naturâ, \& potentiâ alienis); e, finalmente, (iv) que o método solicitado consiste principalmente no conhecimento do intelecto puro, de sua natureza e de suas leis (potissimùm consistat (...) in puri intellectus cognitione, ejusque natura, \& legum). Como o método funciona e por quais meios é possível dele dispor, eu comentarei mais adiante : Por enquanto, basta-me apenas notar que ele consiste — não só mas principalmente (potissimùm) — em certo conhecimento nomológico do intelecto, no conhecimento de suas leis, donde a precisão de que esse intelecto seja "puro", isto é, que apresente sua natureza, sua operação própria, da forma mais autônoma, sem a ingerência de princípios alheios. Essas leis são leis de direção e concatenação de pensamentos; sob elas é que o ato de pensar há de ser - literalmente - regido. A oposição entre arte e acaso (ou fortuna) é, aliás, a oposição entre dois 'regimes': o acaso não é anomia mas sim heteronomia. Ora, era exatamente dessa heteronomia que falavam os Cogitata Metaphysica, quando diziam que os sentidos nos mostram, a cada passo,

155 Carta 37 "an aliqua detur aut dari possit Methodus talis, quâ inoffenso pede in prastantissimarum rerum cogitatione sine tadio pergere possimus? an verò, quemadmodum corpora nostra, sic etiam mentes casibus obnoxia sint, ¿o fortunâ magis, quàm arte cogitationes nostrce regantur?' 
coisas "sem ordem nem conexão (en zonder orde of t'zamenhangin)". É a essa ordem dos encontros heterônomos que Espinosa vem contrapor uma arte de pensar, isto é, uma lógica.

Para os meus interesses, é oportuno aduzir algumas colocações de Larry Laudan sobre Galeno, em sua história das Teorias do método científico ${ }^{156}$. A primeira colocação é a de que um notável ponto fraco na historiografia do método científico foi a preocupação com um pequeno número de textos clássicos. É nesse contexto que Laudan então pergunta, referindo-se ao típico estudioso da matéria: "Saberá alguma coisa, por exemplo, de Galeno?" permite situar a medicina antiga na história da reflexão sobre o método científico e com dissolver isso qualquer sentimento de estranheza frente à aproximação entre o De Emendatione e a tradição médica. E que essa reflexão feita em terreno médico possuiu um lugar fundador na própria história da lógica, é precisamente o parecer de Laudan:

"Outro metodólogo grego de extraordinária importância foi Cláudio Galeno, cuja utilização explícita das técnicas de refutação e confirmação experimentais constituiu, provavelmente, uma das primeiras tentativas de introduzir critérios formais de prova e de argumentação num texto científico. Assim, embora aparentemente tenha sido Aristóteles o primeiro metodólogo a estudar com atenção a estrutura lógica da teoria, Galeno foi o primeiro lógico do teste de teorias. Os principais trabalhos de Galeno sobre metodologia se perderam, mas deles restou um número suficiente para sugerir que as suas idéias, bem como a sua influência, foram de fato muito profundas" $" 158$

Galeno escreve sob a necessidade de precisar - contra os detratores da medicina (notadamente os sofistas) - o estatuto do conhecimento médico presente no Corpus Hippocraticum, do qual foi o principal comentador, o que, portanto, exige a mobilização de temas filosóficos e epistemológicos. Galeno chega a escrever, por exemplo, um texto intitulado "Que o bom médico deve ser um bom filósofo". É nessa oposição frente aos sofistas que parece fazer sentido o desenvolvimento de uma "lógica do teste de teorias", distinta da estrita "estrutura lógica da teoria", pois a medicina não é redutível a uma construção formal. Retomarei a rubrica, trazida por Laudan, de uma

156 Laudan, L. (2000).

157 Laudan, L. Op. Cit. p. 20. Noto, porém, que, neste momento do texto, Galeno não está sendo visado diretamente, comparecendo, antes, junto com outros nomes também pouco freqüentes nas obras de filosofia do método ao tempo em que Laudan publicou seu artigo (1968).

Laudan, L. Op. Cit. p. 29. 
"lógica do teste de teorias", ao discutir as relações da metodologia espinosana com a experiência, mas já posso avançar que tenho aqui em mente o $\S \mathrm{X}$ do De Emendatione .......... De todo modo,

É de notar que Galeno, principal comentador do, tenha escrito um texto intitulado "Que o bom médico deve ser um bom filósofo", revelando, de maneira geral, acentuado interesse por questões filosóficas e epistemológicas, suscitadas pela necessidade de precisar, contra os detratores da medicina (notadamente os sofistas), o estatuto do conhecimento médico. A posição de Galeno parece ser devedora malgrado a falta de referência nominal - do pequeno tratado "Sobre a arte médica" (Peri tekhnés), que pertence ao Corpus Hippocraticum e é "o primeiro documento histórico, se não o único, da maneira pela qual se deu o debate entre os médicos, os filósofos e a sociedade grega clássica no estabelecimento da arte e da ciência médicas" (Cf.). Com efeito, o Sobre a arte médica considera a medicina como uma tekhné, oposta ao acaso (tyche). Essa oposição - na terminologia latina: ars e Fortuna - será explicitamente evocada pelo médico Bowmeester em uma carta a Espinosa e depois retomada por este último em sua resposta (Carta 37), que comentarei brevemente nos próximos passos desta introdução.

Entretanto, a Ars medica de Galeno efetivamente foi revisitada no século XVI por lógicos como Zabarella, justamente a propósito das noções de divisão, análise e síntese $^{159}$, e um contato de Espinosa com o pensamento de Zabarella sobre o método, para além da circulação dessas idéias no meio letrado holandês do século XVII, pode ser cogitado a partir da presença do livro de Keckerman na biblioteca pessoal de nosso filósofo ${ }^{160}$. Mas, ao invés de começar tratando

\section{(b) - Cuidar daquilo com que se cuida do corpo: as Tusculanas de Cícero.}

Deve-se mencionar também os tratados estóicos de vita beata (que falam explicitamente de uma medicina animi, dedicada, como diz Cícero, a cuidar da saúde precisamente daquilo que se usa para julgar as doenças do corpo)

159 Cf. Chauí, Nervura do Real, p.615.

160 "A particular impostação dada por Zabarella à metodologia aristotélica era, pois, mantida viva seja diretamente, através da difusão do filósofo paduano, seja indiretamente, através, por exemplo, da obra de B. Keckerman (...) donde é razoável supor que Espinosa teve conhecimento das temáticas Zabarellianas, senão por via direta, ao menos mediatamente (Espinosa de fato possui o Systema Logicae de Keckerman: Cf. Vuilliaud, 'Spinoza d'apres lês livres...' p. 50-51)”. Biasutti, (1979) p. 104. Zabarella é uma referência de particular importância para meus interesses neste ensaio. 
(c) - Emendatio e reconversão: a antiguidade cristã.

Também devem ser lembrados os textos da antiguidade cristã sobre a conversão da alma a Deus (nos quais, associado às idéias acéticas de esvaziamento e purificação, o termo emendatio comparece para significar a retomada do caminho correto pelo homem decaído ou desviado ${ }^{161}$ ).

\section{(d) - De Humani Corporis Fabrica: a escola de Pádua.}

Ademais, no século XVI, com a modernidade nascente, essa longa e venerável tradição médico-filosófica foi prolongada e transformada, por exemplo, pela escola de medicina de Pádua, eminente nos estudos de anatomia. Entre os séculos XIV e XVII, essa escola foi um dos mais importantes centros de ensino médico da Europa, atraindo muitos estudantes de vários países, dentre os quais, por exemplo, Andreas Vesalius de Bruxelas - autor do famoso tratado anatômico De Humani Corporis Fabrica (1538), que ilustra a fabrica, isto é, a estrutura do corpo humano - e o inglês Wiliam Harvey (em Pádua entre 1597 e 1601), com quem Descartes depois manterá importante debate científico sobre a natureza da circulação do sangue e da função cardíaca ${ }^{162}$. Dentre os paduanos que Chauí registra nessa tradição que leva ao De Emendatione, destaca-se, além do já mencionado lógico aristotélico Zabarella, o médico Agostinho Nifo, autor de um

De Ratione Medendi e de comentários sobre a Física e os Analíticos de Aristóteles ${ }^{163}$ (comentários nos quais Nifo inclusive desenvolve uma teoria sobre quatro graus de conhecimento, dotada de interessantes afinidades com a teoria dos quatro modos de percepção apresentados no De Emendatione).

\section{(e) - Geórgicas da alma: Bacon}

161 De minha parte, noto a presença desse mesmo sentido, preservado no latim corrente do XVII, no interior do próprio epistolário espinosano, na carta 67, enviada a Espinosa pelo fervoroso católico Albrgh Burgh (ex protestante holandês, convertido ao catolicismo em 1673): "os pecadores," inclusive os maiores, sempre observam o devido respeito para com as coisas sagradas, confessam sua própria maldade, acusam-se de seus próprios vícios e imperfeiçõese querem livrar-se deles e, assim, emendar-se / peccatores autem vel maximos semper nibilominùs respectum debitum in Sacra retinere, confiteri suam propriam malignitatem, accusare propria vitia, \& imperfectiones, \& ab illis velle liberari, \& sic emendari"

162 Confira-se o já citado artigo de Regina Rebollo, p. 292, e, para William Harvey e outras informações essenciais à compreensão dessa tradição médico-filosófica, confira-se William Harvey e a anatomia do século XVII: ruptura e tradição, tese de doutoramento, mimeo., São Paulo, 1998, da mesma autora.

163 Cf.Agostino Nifo, Expositio super octo Aristotelis libros. De Physico auditu, Veneza, 1652, apud N. Jardine "Epistemology of sciences", The Cambridge history of renaissance philosophy, Cambridge, 1988, p. 688 (colho essa referência em Chauí, Nervura do Real, Volume de notas, p. 142) 
Entre os autores diretamente citados por Espinosa, essa mesma tradição quinhentista encontra um emblemático representante em Bacon, que, na Instauratio Magna e no Advencement of learning, propõe um cultivo do espírito, inspirado nas Geórgicas de Virgílio. Nestas "Geórgicas da alma", Bacon compara o trabalho do filósofo tanto ao do médico-anatomista quanto ao do jardineiro e do agricultor, isso conotando, como foi dito mais acima, não apenas a cura mas sobretudo o cuidado do intelecto, no sentido da manutenção de sua saúde através de um cultivo terapêutico e profilático da dinâmica vital do jardim da alma ${ }^{164}$.

\section{(f) - $\mathrm{O}$ aristotelismo judaico da baixa idade média: Gersônides.}

Aaron Garrett também confere, em livro recente, grande importância à idéia de uma "emendative therapy", considerando que "a mais importante função do mos geometricus está ligada àquilo que Espinosa chama de 'emenda' no TIE"'165, ou seja, ao trabalho de liberação da mente das idéias inadequadas e da dinâmica imaginativa. Essa terapia não é, nas palavras do comentador,

"um mero conhecimento formal ou anatomia de nossa mente, mas antes a descoberta e o aumento daqueles mesmos poderes desde sempre presentes no corpo e na mente humana. Essa descoberta é um processo de 'tornar-se o que se é', para usar a famosa expressão de Nietzsche, reconhecendo que o ser que sempre fomos era diferente da miríade de maneiras pelas quais nos representamos via imaginação"166.

A despeito da referência a Nietzsche - interessante, em todo caso, por já sugerir que a emendatio espinosana é distinta da emendatio ascética da antiguidade cristã , as bases históricas em que A. Garrett de fato fundamenta sua caracterização da "emendative therapy" são, em boa parte, as mesmas já anteriormente levantadas por Chauí: a tradição estóica, Zabarella, Bacon e Descartes (que comentarei logo a seguir). Muito embora a investigação de Chauí seja mais ampla, Garrett tem o mérito de conceder - sem os excessos de um Wolfson — bastante atenção à influência do aristotelismo judaico da baixa idade média sobre Espinosa, e em especial à influência de

\footnotetext{
${ }^{164}$ Empregando termos muito anacrônicos, mas elucidativos do que tenho em vista ao insistir na tradução de curare como cuidar, eu arriscaria a falar, no caso de Espinosa, de uma "ecologia da mente", que zela pela consistência sistema psíquico, garantindo que este reproduza o mesmo modelo da Natureza.

${ }^{165}$ Garrett, A (2003) p. 17.

${ }^{166}$ Idem ibidem
} 
Gersônides ${ }^{167}$. Com efeito, defendendo que a formação filosófica não prejudica mas, antes, contribui para o cultivo da religião, Gersônides estabelece sete princípios metodológicos para o tratamento de questões metafísicas e teológicas fundamentais, tais como "se o universo foi criado e de que maneira". Esses princípios metodológicos, como mostra Garrett, são, em sua maioria, preceitos lógicos, de inspiarção aristotélica, para a correção formal da argumentação ${ }^{168}$. É no sexto princípio que se encontra o ponto de maior interesse para a presente discussão sobre a lógica como Medicina Mentis:

"um autor compreende que algumas de suas discussões expõem coisas que são estranhas ao leitor, por causa das opiniões com as quais este último está familiarizado e habituado desde a infância. Deste modo, o leitor perturba-se com essas discussões até mesmo quando não encontra nelas nenhuma inconsistência lógica, fuçando, então, incapacitado de obter conhecimento do resto do livro. Por isso, o autor dever arranjar o material de forma apropriada à sua transmissão ao leitor (...) Esse tipo de tática é similar à empregado pelos fisiólogos do corpo e da mente, e é necessário usá-la por causa da disposição do paciente. Um tal doente precisa ser introduzido gradualmente à terapia (...) Por tanto, quando um autor compreende que o leitor tem opiniões distorcidas, que pretende contradizer, deve desarraigá-las gradualmente (...) razão pela qual o autor deve tentar dissipar aquilo que nutre essas opiniões antes de efetivamente tentar desarraigá-las."

Não é somente a explícita referência a uma estratégia terapêutica — inserida num contexto lógico, de inspiração aristotélica, sobre as regras da demonstração — que aqui deve ser notada, mas também o fato de que essa estratégia diz respeito à estrutura simultaneamente lógica e retórica do discurso (a disposição do paciente). Mas nao é só psicológica: a regra 1 diz: tem que ir do conhecido ao desconhecido; logo, deve-se partir

167 Chauí também se refere - e não pouco - a Gersônides, mas sobretudo a propósito de temas diretamente metafísicos e teológicos, ao passo que Garrett centra suas referências no contexto da noção de emendatio. Garrett dedica, nessa chave, um capítulo inteiro a Maimônides e Gersônides (Meaning in Spinoza's Method Chap. 5). Refiro-me, porém, exclusivamente a Gersônides porque, assim como Espinosa, ele se posiciona antes como um crítico do que como um seguidor de Maimônides, em especial no que diz respeito ao não rompimento com princípios propriamente racionais na elaboração de um método filosófico (Cf. Garrett, Op. Cit. p. 134).

168 Resumidos por Garrett, tais princípios são: (1) O conhecimento de algumas coisas é, por natureza, anterior ao conhecimento de outras, e um pequeno erro no conhecimento das primeiras leva a grandes erros no conhecimento das últimas; (2) o mais específico se demonstra com base no mais geral; (3) quando em chave pedagógica, uma exposição filosófica deve ir do mais fácil e conhecido ao mais difícil e desconhecido, e não o contrário; (4) uma sentença da qual dependem muitas outras deve ser provada antes e independentemente delas; (5) a solução de um dilema deve preceder a asserção de qualquer uma de suas partes; e (7) um discurso filosófico deve ser auto-suficiente para demonstrar o que propõe e, portanto, deve dispensar o recurso a autoridades externas Cf. A. Garrett, Op. Cit. pp. 137-139. É de notar, em favor de minha estratégia no presente ensaio, que Garret caracterize o pensamento de Gersônides como fortemente marcado pelo de Aristóteles: "Gersônoides is a radical Aristotelian" (Op. Cit. p 137, nota 30). 
de onde o seu interlocutor se encontra: do nada, nada se faz, ou seja, o que quer que o leitor possa aprender, ele aprenderá por via do que já tem dado.

\section{(g) - As paixões da alma: Descartes.}

Finalmente, dentre as principais influências históricas, não pode ser omitido o Traité des passions de l'âme, de Descartes (citado por Espinosa no mesmo prefácio de Ethica $V$, de onde provêm as referências à lógica e à medicina), ainda que o filósofo francês oponha-se veementemente a essas tradições antiga, medieval e renascentista. Essa oposição, entretanto, contesta especificamente as matrizes humanistas, de jaez moral e retórico, e não impede - muito pelo contrário, especifica - que o tratado aborde as paixões da alma ${ }^{169}$ segundo o paradigma da fisiologia (en physien) ${ }^{170}$. Com efeito, das tradições anteriores, Descartes não recusa a adoção da perspectiva médicofisiológica, mas, ao contrário, sua não adoção estrita e completa: o erro dos antigos teria sido o recurso precoce à alma na explicação, por exemplo, do movimento do corpo. Só depois de verificar tudo o que pode o corpo sozinho (absque opera animae) é que Descartes começa a determinar em que a alma se faz necessária. O que é anímico fica, portanto, delimitado negativamente como o incorporal, de modo que a determinação das functiones animae (iniciada no décimo-sétimo artigo do Traité) torna-se relativa e devedora da determinação das partes et functiones corporis (que ocupa os artigos de 1 a 16). Isso se evidencia, no artigo 17, quando da conclusão de que, uma vez determinadas as partes e as funções do corpo, "nada resta (nibil restare) em nós que devamos atribuir à alma exceto nossos pensamentos"171. O pensamento é o que "resta" atribuir à alma quando se exige uma explicação do funcionamento corpo sem princípios ex machina. Mas o que eu gostaria, então, de salientar, a título de influência sobre Espinosa, é que Descartes está dizendo com isso que o corpo pode mais do que os antigos supuseram, vindo a caracterizar essa suficiência através da idéia de uma máquina que se move a si mesma

\footnotetext{
169 Mantenho aqui a distinção de vocabulário entre Espinosa e Descartes: quando me refiro ao primeiro, emprego o termo alma para traduzir anima, e quando me refiro ao segundo, emprego mente, para traduzir mens. Que os dois conceitos são grosso modo correlatos, evidencia-se pelo uso que Espinosa faz da expressão "animam seu mentem / alma ou mente", por exemplo, na frase: "Nam [Cartesius] statuit animam seu mentem unitam prccipue esse cuidam parti cerebri, glandula scilicet pineali dictce / Pois [Descartes] estabelece que a mente está unida principalmente a alguma parte do corpo, qual seja, a chamada glândula pineal"; Ethica V, praef.

$170 \quad$ Cf. Descartes, Les passions de l'âme, AT, XI, pp. 327 e 328.

171 Descartes, Passiones Animae, articulus 17: "Postquam ita consideravimus omnes functiones quae pertinent ad solum corpus, facile est cognscere nibil in nobis restare quod debeamus tribuere nostrae animae, exceptis nostris cogitationibus"
} 
(machina quae sponte mevetur), isto é, de um automaton ${ }^{172}$.

Ora, na proposição 2 de Ethica III, Espinosa afirma que "Nem o corpo pode determinar a mente a pensar, nem a mente determinar o corpo ao movimento ou ao repouso, ou (se é que isso existe) a algo mais" ${ }^{\text {"17 }}$. E no escólio da mesma proposição, considera justamente que ninguém até o momento determinou o que o corpo pode fazer (agere) só pelas leis da natureza corpórea: "ninguém até aqui (bucusque) conheceu tão acuradamente a fabrica do corpo (corporis fabricam), que pudesse explicar todas as suas funções (omnes ejus functiones)". Os homens crêem que é necessário admitir uma ação da mente sobre o corpo, como causa, por exemplo, da existência de coisas fabricadas com arte (arte fabricatae) ${ }^{174}$, tais como os edifícios e as pinturas. Mas a isso Espinosa responde que muitas coisas feitas pela natureza possuem, sem a necessidade de uma causa mental, o caráter que os homens crêem ser apanágio da ars: comparada até mesmo a um templo ordenadamente concebido e edificado (cujo exemplo paradigmático é o Templo de Salomão, construído com eminente sabedoria), a própria fabrica do corpo humano (bumani corporis fabricam) ${ }^{175}$ é de um artifício ${ }^{176}$ muitíssimo superior (quae artifício longissime superat). Como se vê, Espinosa se mantém fiel ao preceito cartesiano de não recorrer precocemente a princípios anímicos para explicar o que se passa no âmbito corporal. Mas esse cartesianismo espinosano possui - aqui como em outros contextos - a

172 É nesse contexto que se situa, por exemplo, a supra mencionada polêmica com Harvey acerca da circulação do sangue e da função cardíaca, cujo fundo filosófico mais amplo me parece ser um debate sobre a modelagem do autômato, pensada — sob a égide do axioma platônico da perfeição dos movimentos circulares - como um sistema cíclico iterativo (Cf. iterum, no artigo 7) de movimentos e sub-movimentos complementares (agônicos e antagônicos), pois é nisso que consiste uma "circulação" ou um tour, como diz Descartes. A fonte de energia desses movimentos é, na fisiologia cartesiana, o "calor" do coração, órgão que, para Harvey, é um músculo, ou seja, ao passo que Descartes considera os músculos como partes movidas e não moventes primeiros. Nesses termos, embora Descartes estivesse errado do ponto de vista fisiológico, do ponto de vista lógico, sua divergência com Harvey teria a forma de uma acusação de petição de princípio, pois, conquanto adequada empiricamente, a teoria de Harvey explicaria o movimento dos músculos pelo movimento de um músculo, sem situar no próprio corpo um verdadeiro princípio de movimento de outra ordem (tal como é o calor cardíaco para Descartes, que o relaciona inclusive com o calor e a luz presentes, em macro escala, na sua cosmologia, como se vê na quinta parte do Discurso do Método).

EII, p2: "Nec corpus mentem ad cogitandum nec mens corpus ad motum neque ad quietem nec ad aliquid (si quid est) aliud determinare potest"

Idem ibidem: "At dicent ex solis legibus naturce quatenus corporea tantum consideratur, fieri non posse ut causce cedificiorum, picturarum rerumque bujusmodi qua sola bumana arte fiunt, possint deduci nec corpus humanum nisi a mente determinaretur ducereturque, pote esset ad templum aliquod cedificandum"

$175 \quad$ Note-se que esta expressão de Espinosa é absolutamente idêntica ao título do tratado anatômico - uma espécie de Atlas ilustrado do corpo humano — do mencionado Adreas Vesalius de Bruxelas: De Humani Corporis Fabrica (publicado em 1543).

176 O termo artificium não pode ser aqui, evidentemente, entendido como algo artificial em oposição a algo natural. O termo latino comporta as idéias de (1) o ofício de um artífice, (2) uma capacidade de fabricar, (3) o caráter engenhoso de uma obra. 
peculiar característica de levar às últimas consequiências a influência inicial, promovendo transformações e rupturas. Afinal, Espinosa volta contra Descartes a mesma censura que este último dirigira aos antigos, pois considera que, havendo concebido a relação entre mente e corpo como uma união substancial, necessária para que a mente aja sobre o corpo e vice versa, o próprio cartesianismo recorreu precoce ou melhor - desnecessária e indevidamente a princípios ex machina para explicar algo do que se passa no corpo. Como diz Espinosa no célebre escólio da proposição 7 de Ethica II, quando consideramos as coisas como modos da extensão, devemos explicar a ordem da natureza inteira, ou seja, a conexão das causas (ordinem totius natura sive causarum connexionem), estritamente pelo atributo da extensão (per solum extensionis attributum).

\section{(1.2.2) O Caráter Lógico Da Medicina Mentis No Contexto Da Crítica De Espinosa}

\section{Ao Dualismo Cartesiano}

Consequentemente, para Espinosa, o pensamento não mais se situa como o nãocorporal - embora evidentemente não seja corporal — no sentido de que não é mais definido como o resíduo que remanesce inexplicado através da natureza da extensão, já que ambos os atributos são suficientes para explicar a ordem da natureza inteira, cada qual com seus próprios nexos causais, sem causalidade inter-atributiva. Os atributos não possuem fronteiras entre si, são sempre exaustivos, ou melhor, nos termos da primeira parte da Ethica, são infinitos em seus gêneros. A diferença entre gêneros admitida por Espinosa é, segundo a definição 2 de Ethica I, uma diferença de natureza, e coisas de naturezas distintas não terminam, não limitam — nem delimitam ou definem — umas as outras:

"diz-se finita em seu gênero aquela coisa que pode ser limitada (terminari potest) por outra de mesma natureza (alia eiusdem naturae). Por exemplo, um corpo é dito finito por sempre concebermos outro maior (majus). Assim também um pensamento é limitado por outro pensamento. Mas um corpo não é limitado por um pensamento, nem um pensamento por um corpo"177.

A diferença de gênero, enquanto diferença de natureza, significa uma alteridade

177 Ethica I def. 2: "Ea res dicitur in suo genere finita que alia ejusdem naturce terminari potest. Exempli gratia corpus dicitur finitum quia aliud semper majus concipimus. Sic cogitatio alia cogitatione terminatur. At corpus non terminatur cogitatione nec cogitatio corpore" 
irredutível, que freqüenta as passagens iniciais da Ethica presidindo o conceito de "coisas que nada possuem de comum entre si" (res quae nibil commune inter se babent), e que são justamente aquelas que não podem ser concebidas uma através da outra nem manter interações causais recíprocas ${ }^{178}$. Desponta, assim, um aspecto lógico da censura de Espinosa, por exemplo, à hipótese cartesiana da glândula pineal (essa "parcelazinha de quantidade" a que o pensamento se ligaria) ${ }^{179}$ : ela supõe uma fronteira de trocas entre naturezas distintas, supõe gêneros que se delimitam e interagem, quando, no entanto, o gênero é a própria condição de possibilidade de todas e quaisquer delimitações e interações, o que configura um erro formal - sc. submeter a condição (o gênero) ao condicionado (delimitação e interação) — no conceito cartesiano da relação entre mente e corpo. É certo que, segundo Espinosa, tais atributos se distinguem entre si — pois, de um único gênero infinito, infinitos outros gêneros infinitos podem ser negados ${ }^{180}$-, mas isso não implica que eles se delimitem (o que precisamente destruiria sua infinitude); pelo contrario, eles não se delimitam na medida mesma em que são distintos. São diferentes, diversos, e não opostos, pois os opostos - já ensinava Aristóteles! — só podem ser do mesmo gênero, não havendo oposição entre ser homem e estar na ágora, mas sim entre características, por assim dizer, laterais, tais como ser homem ou ser cavalo, ou entre estar na ágora ou estar no liceu.

Que uma versão espinosana dessa distinção entre gêneros está operando na referida crítica de Espinosa a Descartes e, assim, na caracterização do que seja para o primeiro uma Medicina Mentis, é algo que pode ser verificado no epistolário de nosso filósofo. As Cartas a que me refiro (i.e a Hudde, Jelles e Blijenbergh) são bem mais amplas e complexas do que os breves excertos que ora seleciono, mas creio que neles podem ser recolhidas informações suficientes para mostrar como a operação lógica da distinção entre gêneros se faz relevante para a caraterização do que seja a Medicina Mentis espinosana. Começo, pois, pela seguinte passagem da Carta 36, a Hudde:

178 Cf. Ethica I, ax 4: "Effectus cognitio a cognitione causa dependet et eandem involvit"; Ethica I, ax. 5: "Qua nibil commune cum se invicem habent, etiam per se invicem intelligi non possunt sive conceptus unius alterius conceptum non involvif' e Ethica I, prop 3: "Qua res nibil commune inter se habent, earum una alterius causa esse non potest'.

179 Essas censuras de Espinosa à hipótese cartesiana da glândula pineal estão contidas principalmente no já mencionado prefácio de Ethica $V$, logo depois da referência feita à lógica e à medicina.

$180 \quad$ Cf. E I, def 6, explicatio: "quicquid enim in suo genere tantum infinitum est, infinita de eo attributa negare possumus / pois o que é infinito em seu gênero, disso podemos negar infinitos atributos" 
"ainda que a extensão negue de si o pensamento, isso, todavia, não é qualquer imperfeição nela. $\mathrm{Na}$ verdade, se fosse destituída de extensão, isto sim provaria nela alguma imperfeição, como de fato ocorreria se fosse determinada (determinata, i.e. delimitada) e, semelhantemente, se carecesse de duração, de posição, etc. (...) Aqui eu gostaria de notar o que já disse a respeito do vocábulo 'imperfeição', a saber, que ele significa que a alguma coisa falta algo que, no entanto, pertence à sua natureza (quod tamen ad suam naturam pertinet). A extensão só pode ser dita imperfeita com respeito, por exemplo, a duração, posição, quantidade, isto é, se não durasse muito, se não retivesse sua posição ou se não pudesse ser maior (major non evadit); nunca, porém, se diz imperfeita por não pensar, uma vez que sua natureza nada exige de tal sorte, pois consiste na só extensão, isto é, em certo gênero de ente (hoc est, in certo entis genere), e somente a respeito dele deve ser dita determinada ou indeterminada, perfeita ou imperfeita", 181

Como se vê, não há comparação possível entre entes tomados sob gêneros diversos: a extensão só pode ser tomada em termos de características extensas, e o pensamento, em termos de características mentais. E isso ajuda a compreender melhor o sentido do exemplo da supra citada definição 2 de Ethica I: "um corpo é dito finito por sempre concebermos outro maior (majus)". Pois a Carta 36 torna patente que o importante nesse exemplo é que o termo majus é de natureza extensa, e não que o princípio espinosano de delimitação dos corpos seja exatamente a relação maior/menor, e muito menos que se deva esperar que um pensamento seja finito porque sempre podemos conceber um outro que lhe seja maior. Aliás, Espinosa realmente não diz isso na parte do exemplo que cabe ao pensamento; muito embora também não diga qual seria o análogo mental para majus. Em todo caso, está clara a intenção de levar às últimas consequiências a impossibilidade de concebermos o pensamento em termos

$181 \quad$ Carta 36, a Hudde: "quamvis ex. gr. extensio de se cogitationem neget, nulla tamen hoc ipsum in eâ est imperfectio. Hoc verò, si nimirum extensione destitueretur, in eâ imperfectionem argueret, ut reverâ fieret, si esset determinata, similiter si duratione, situ \&o. careret (...)Hî̀ loci, quod modò dixi, notari vellem, quantum vocabulum imperfectionis spectat, nimirùm illud significare rei alicui quicquam deesse, quod tamen ad suam naturam pertinet. Ex. gr. Extensio solummodò respectu durationis, sitûs, quantitatis imperfecta dici potest; nimirùm quia non durat longiùs, quia suum non retinet situm, vel quia major non evadit; Nunquam verò, quia non cogitat, imperfecta dicetur, quandoquidem ejus natura nihil tale exigit, qua in extensione sola consistit, hoc est, in certo entis genere: quo respectu tantùm determinata aut indeterminata, imperfecta aut perfecta dicenda est'. Veja-se também, na mesma carta, no trecho que saltei em minha citação, a seguinte passagem, em que é explícita a caracterização do pensamento e da extensão como perfeitos (isto é, completos e exaustivos) em seus gêneros, diferentemente de Deus, que é absolutamente infinito: "Si ex. gr. statuere volumus, extensionem, aut cogitationem (qua qualibet in suo genere, hoc est, in certo genere entis, perfectce esse queunt) suâ sufficientiâ existere; etiam existentia Dei, qui absolutè perfectus est, hoc est, entis absolutè indeterminati erit concedenda." 
espaciais e vice-versa. A reconstrução que, então, proponho para o exemplo da delimitação corporal é a seguinte: se A é majus em relação a $\mathrm{B}$, eles se diferenciam em tamanho e, portanto, não são o mesmo quanto a algo que cabe propriamente a corpos, donde A e B serem dois corpos. O que está sendo ilustrado é que só há distinção numérica, só há numerador (e.g. dois, isto é, um e outro), mediante um mesmo denominador, um mesmo gênero (e.g corpos, coisas extensas). E que o denominador a presidir a distinção numérica seja o gênero, é algo que Espinosa deixa patente, por exemplo, na Carta 50 a Jarig Jelles:

"uma coisa é dita uma ou única somente com respeito à existência, mas não à essência: com efeito, não concebemos as coisas sob o número (sub numeris) senão depois que foram reunidas num gênero comum (nisi postquam ad commune genus redactce fuerunt). Por exemplo, quem segura na mão um Sestércio e um Imperial não pensa no numero dois, a não ser que possa chamar (nisi queat se vocare) esse Sestércio e esse Imperial por um e mesmo nome (uno eodemque nomine), qual seja, de dinheiros ou de moedas; pois então pode afirmar possuir dois dinheiros ou moedas, já que assinala (insignit) não somente o Sestércio mas também o Imperial pelo nome de dinheiro ou moeda. Donde, portanto, claramente se evidencia que nenhuma coisa se denomina uma ou única ${ }^{182}$ (unam, aut unicam nominari) senão depois que foi concebida outra coisa que (como está dito) convém com ela (cum eâ convenit)" ${ }^{\text {"183 }}$

Como, portanto, não há comparação ou comensurabilidade possível entre gêneros, um não está privado - e pela mesma razão, não pode ser recebedor — do que quer que pertença à natureza do outro. Donde, o próprio gênero não poder ser limitado por outro mas apenas negado dele. Como diz Espinosa na Carta 21, a Blijenbergh, é

182 Note-se, a propósito, que quando falo de distinção numérica não me limito a numerais como 2, 3, 4 etc., mas também a quantidades indeterminadas como único ou múltiplo. Mediante esta observação, baseada na Carta 50, definição de coisa finita de Ethica I, porque fala de "um corpo e outro corpo maior", ou de "um pensamento e outro pensamento", ou seja, porque fala de "um e outro do mesmo", caracteriza a distinção entre as coisas finitas como uma distinção numérica, ainda que não mencione qualquer numeral.

Carta 50 a Jarig Jelles : "rem solummodò existentic, non verò essentice respectu unam, vel unicam dici: res enim sub numeris, nisi postquam ad commune genus redactc fuerunt, non concipimus. Qui, verbi gratiâ, sestertium, \& imperialem manu tenet, de numero binario non cogitabit, nisi bunc sestertium, \& imperialem uno, eodemque, nempe nummorum, vel monetarum, nomine vocare queat: nam tunc, se duos nummos, vel monetas habere, potest affirmare; quoniam non modò sestertium; sed etiam imperialem nummi, vel moneta nomine insignit. Hinc ergo clarè patet, nullam rem unam, aut unicam nominari, nisi postquam alia res concepta fuit, qua (ut dictum est) cum eâ convenit' 
apenas quando comparamos, por exemplo, um homem cego com outros igualmente considerados como homens, que supomos que o primeiro está privado de visão;

"mas quando se considera o decreto de Deus e sua natureza, não temos mais razão para dizer que esse homem está privado de visão do que está a pedra, já que, neste momento, é tão contraditório atribuir a visão a esse homem quanto à pedra. Porque a esse homem nada mais pertence e é seu senão o que lhe atribuem o intelecto e a vontade de Deus. E por isso, Deus não é mais causa do seu não-ver ( $\tau o v$ illius non videre) do que do não-ver da pedra ( cov non videre lapidis), o qual é mera negação"184

A um cego nada falta, se esse indivíduo for considerado em sua absoluta singularidade, ou seja, como Deus o conhece, pois Deus nada abstrai nem forma definições gerais (Deus res nec abstractè novit, nec id genus generales format definitiones) ${ }^{185}$. Nesse caso, pelas razões apresentadas na carta 50, eu diria que Deus conhece cada indivíduo não como um ou único mas sim como algo sui generis, isto é, incomparável e incomensurável em si mesmo, como é o próprio gênero na singularidade de sua natureza ${ }^{186}$. Ora, como todo gênero já é necessária e imediatamente sui generis, com tanto

$184 \quad$ Carta 21, a Blijenbergh: "Verùm quum Dei decretum, ejusque natura consideratur, non magis de illo homine, quàm de Lapide possumus affirmare, eum visu orbatum esse, quia illo tempore non magis sine contradictione illi homini visus, quàm lapidi competit; quoniam ad hominem illum nil amplius pertinet, \& suum est, quam id, quod Divinus intellectus \& voluntas ei tribuit. Et propterea Deus non magis est causa tou illius non videre, quam tou non videre lapidis: id quod mera est Negatio"

185 Carta 19, a Blijenbergh. Já foi dito no RESUMO que a teoria espinosana da definição inclui uma crítica à definição aristotélica por gênero e diferença específica. Esse assunto será retomado mais adiante (Cf. Cf.). Não obstante essa crítica, Espinosa também dota o termo gênero de um significado positivo e legítimo na constituição de importantes conceitos de seu sistema, como pretendo haver demonstrado aqui, ligando a correspondência à definição 2 de Ethica I. Objeções a esta minha valorização do uso positivo da noção de gênero em Espinosa poderiam apelar justamente para a Carta 19. Em primeiro lugar, poderiam recorrer à idéia de que "tudo o que é, quando considerado em si mesmo, sem ser a respeito de algo outro, inclui perfeição, a qual se estende em qualquer coisa até onde se estende a própria essência da coisa"; e, em seguida, notariam que, no entanto, a privação recebe um nome (e.g. cegueira) e se nos afigura como algo de positivo, justamente "porque, com uma só e a mesma definição, exprimimos todos os singulares reunidos (cuncta) num mesmo gênero" (e.g. homem). O gênero, então, supostamente seria uma noção contrária ao reconhecimento da perfeição intrínseca do singular. Todavia, além de não apagar a operatividade textual da noção de gênero, a objeção se esquece do seguinte: um indivíduo, considerado em si mesmo, é incomensurável, assim como entes de gêneros distintos também o são; mas, para que haja indivíduos que se distingam entre si, é necessário justamente que eles sejam do mesmo gênero. A noção de gênero não é antagônica à de indivíduo; pelo contrário, ela lhe é profundamente solidária: sem gênero, nada de corpo finito nem de mente finita. Ademais, em seu uso positivamente espinosano, a noção de gênero não funciona como fator ou efeito de uma aglutinação (cuncta) que violenta singularidades, mas justamente como princípio que zela pela incomensurabilidade entre pensamento e extensão, defendendo uma posição que não recai nem em um dualismo de tipo cartesiano, nem em um reducionismo materialista ou idealista.

186 Valho-me, aqui, do uso corrente da expressão sui generis para significar "sem semelhança com nenhum outro, original, singular". Todavia, rejeito, pelas razões apresentadas na Carta 50, a tradução "único do gênero", preferindo a perífrase "singular como o gênero" ou a tradução literal 
mais razão do que no caso do cego deve-se dizer que negar um atributo de outro (e.g. 'a extensão não pensa' ou 'o pensamento não é extenso') não passa disso mesmo, ou seja, de mera negatio. E o mesmo vale para modos finitos sob distintos atributos, como quando se diz que a idéia do círculo não tem centro e periferia: novamente, trata-se de uma negatio stricto sensu, pois a idéia verdadeira do círculo é - em letra espinosana - algo diversum à suo ideato, assim como a idéia do corpo é algo diversum do próprio corpo ${ }^{187}$. Entre os diversos só há mera negatio.

Aliás, é precisamente uma tal diversidade que desfaz a aparente contradição entre esta afirmação de TIE $\int 33$ — "a idéia do corpo não é o próprio corpo" (nec idea corporis est ipsum corpus) - e a conhecida afirmação, feita no escólio de Ethica II, prop 7, de que, não obstante, "um modo da extensão e a idéia desse modo são uma só e a mesma coisa" (modus extensionis et idea illius modi una eademque est res). A asserção de identidade na Ethica não é verdadeira em prejuízo da asserção de diversidade do TIE; bem ao contrário, ela lhe é devedora, pois é apenas por serem diversos, ou seja, de gêneros distintos e, portanto, não laterais, que mente e corpo não colidem ao serem, ao mesmo tempo, uma só e mesma coisa. Ademais, essa diversidade também é reconhecida pelo próprio escólio que afirma a identidade em Ethica II, prop 7; pois aí Espinosa diz que um modo da extensão e a idéia desse modo são uma só e a mesma coisa... expressa de dois modos (duobus modis expressa). Não estamos diante de duas coisas, mas de uma mesma coisa diversamente expressa. Afirmar a diversidade de gênero é condição de possibilidade de afirmar a unidade da coisa.

Já para Descartes, a distinção entre mente e corpo, admitindo encontros, delimitações e interações entre ambos, não os caracteriza mediante a diversidade de gêneros, mas sim — nos termos do Traité des passions de l'âme - como dois sujeitos: “isso que é paixão com respeito a um sujeito (respectu subjecti unius) é sempre uma ação com respeito a outro (respectu alterius) ${ }^{" 188}$. Portanto, segundo Descartes, numa interação entre alma e corpo, o que é ação da alma é paixão no corpo, e o que é ação do corpo é paixão na alma, numa relação de proporção inversa que possui o estatuto lógico de uma

\footnotetext{
“de seu gênero" (sem qualquer referência à idéia de um ou único).

TIE §33: "Idea vera (habemus enim ideam veram) est diversum quid à suo ideato: Nam aliud est circulus, aliud idea circuli. Idea enim circuli non est aliquid, habens peripheriam, \& centrum, uti circulus, nec idea corporis est ipsum corpus"

188 Descartes, Passiones Animae, articulus 1: "una eademque res, quae hae duo habeat nomina ratione duorum diversorum subjectorum ad quae referri potest'
} 
oposição. Mente e corpo - como dois sujeitos substanciais e não como uma mesma coisa sob distintos atributos - colidem, disputam, rivalizam, na misteriosa unidade do homem cartesiano. Em Descartes, passio e actio é que são "uma só e mesma coisa" (una eademque), que recebe dois nomes distintos conforme seja referida a um ou outro desses dois sujeitos, a mente e o corpo. Em Espinosa, ao contrário, um corpo e a idéia desse corpo é que ficam na condição de "uma só e a mesma coisa", compreendida sob (sub) atributos distintos, ou expressa de duas maneiras (duobus modis), ou explicada através de (per) atributos diversos, ou ainda, causada por Deus enquanto (quatenus) ele é pensante ou enquanto (quatenus) ele é extenso. E assim, quando a mente age, isso já é também, desde sempre, uma ação do corpo, e vice-versa, visto que nada começa em um para terminar no outro ${ }^{189}$. Mas, o que mais quero ressaltar no momento é que, nas fórmulas "comprehenditur sub", "per diversa attributa explicatur", "quatenus est" e "duobus modis expressa", é a variação de gênero que constitui o lastro semântico do advérbio quatenus, das preposições sub e per e do ablativo duobus modis ${ }^{190}$; é a ela que reenviam esses elementos sincategoremáticos ${ }^{191}$.

Creio que isso demonstra suficientemente que trata-se aí de um operador lógico controlando as diferenças entre Espinosa e Descartes quanto à 'relação' entre a mente e o corpo. Tanto é que, segundo Espinosa, aqueles que dizem que a mente é a causa de uma ação do corpo, ou vice versa, mostram que não sabem o que dizem (nescire quid dicant) e que, embaraçados com palavras enganadoras (speciosis verbis), simplesmente não

189 Em termos anacrônicos, eu diria que, para Espinosa, não há processos psico-somáticos, no sentido de algo que começa na mente e termina no corpo. Ou seja, a expressão "psico-somático" é mal construída e padece de um erro lógico, se o hífen entre as palavras indicar uma relação de causalidade. Mas, ao contrario, tudo que se passa em nós será, segundo Espinosa, psico-somático, se o sentido do hífen for o de identidade e simultaneidade: tudo o que acontece em nós é sempre e simultaneamente um evento psíquico e um evento somático.

$190 \quad$ Poderia parecer que Espinosa desliza em uma equivocidade ao dizer, no escólio de Ethica II, prop 7, que "modus extensionis et idea illius modi una eademque est res sed duobus modis expressa", pois emprega a mesma palavra modo em dois sentidos diferentes (sc. como afecção da substância, nas duas primeiras ocorrências, e, em sentido lato, como maneira, forma, jeito, na última), aparentemente sem advertências dessa variação. Todavia, trata-se de mera aparência, pois a variação de sentido está sinalizada, no contexto sintático da frase latina, pelo uso do ablativo na última ocorrência. Em meu entender, o que importa não é a repetição do étimo mas a variação do caso em que ele se declina, qual seja, o ablativo de modo ou maneira, que mostra como algo é feito (e.g. summa celeritate pervenit $=$ ele chegou com grande rapidez). É de notar, a propósito, que um adjetivo nesse ablativo pode funcionar inclusive como um advérbio (e.g. iure = legalmente; forte = casualmente).

A noção de gênero não significa nem exatamente o que é compreendido, explicado, causado ou expresso, nem exatamente o que compreende, explica, causa ou expressa, mas sim sob o que se dá a compreensão, através do que se dá a explicação, enquanto oque se dá a causalidade, de queque maneira se dá a expressão. 
sabem a causa dessa ação (veram illius actionis causam ignorare ${ }^{192}$. Descartes, nesta medida, teria cometido um dos erros de que ele próprio mais censurara os escolásticos, a saber, "admitir uma hipótese mais oculta do que todas as qualidades ocultas"193. Perguntar pela causa mental de um evento corporal ou vice-versa consiste, nesta medida, em um duplo erro. A menção de Espinosa às "qualidades ocultas" revela, primeiramente, que a causa visada - como na famosa blague de Moliere sobre a virtus dormitiva - correrá o risco de figurar como um oculto suporte ad hoc para o efeito, suporte que nada mais é que o próprio efeito retroprojetado no lugar da causa ${ }^{194}$. Mas, em segundo lugar, outro erro já se configura na pergunta mesma, a saber, o salto entre gêneros, como se alguém perguntasse em termos de lugar qual a causa de alguém ser homem. A resposta até poderia ser verdadeira (e.g. tal homem realmente está em tal lugar), mas não para a pergunta feita (e.g. não é homem por estar em tal lugar). Estimo ser por isso que a hipótese cartesiana é mais oculta do que todas as qualidades ocultas, pois nela Espinosa diagnostica não só a retroprojeção do efeito mas também aquilo que, na moderna filosofia da linguagem — penso aqui em G. Ryle — veio a ser chamado de "erro categorial" (tão mais insidioso quanto mais o uso gramaticalmente correto da linguagem camuflar a infração lógica do pensamento) ${ }^{195}$.

192 Ethica III, prop 2, escol.

193 Ethica V, praef. "Profecto mirari satis non possum quod vir philosophus qui firmiter statuerat nibil deducere nisi ex principiis per se notis et nibil affirmare nisi quod clare et distincte perciperet et qui toties scholasticos reprehenderat quod per occultas qualitates res obscuras voluerint explicare, bypothesin sumat omni occulta qualitate occultiorem"

194 Voltarei a esse problema ao comentar a diferença entre razão e intuição no TIE, articulada com a diferença entre definição pela propriedade e definição pela essência.

195 "[uma] lacuna, num esquema de sentença dado, pode ser preenchida por alguns complementos alternativos, mas não por quaisquer complementos alternativos. Há aqui, porém, dois tipos de pode. Assim e assim está na cama exige gramaticalmente, como complementos para a lacuna indicada por assim e assim, substantivos, pronomes ou frases substantivas, como as frases descritivas. Assim, Sábado está na cama não infringe nenhuma regra de gramática. Apesar disso, a sentença é absurda. Não basta apenas, por conseguinte, que os complementos possíveis sejam de determinados tipos gramaticais; é necessário também que eles exprimam fatores proposicionais pertencentes a certos tipos lógicos" - Ryle, G. Categorias in Col. Os Pensadores - Ryle, Austin, Quine, Strawson. São Paulo, Abril Cultural, 1980, p. 26. Ora, o que, de minha parte, estou dizendo a propósito da crítica de Espinosa a Descartes é que, num enunciado do tipo: $x$ é causa de tal evento corporal, o preenchimento da lacuna $\mathrm{x}$ por qualquer termo anímico, conquanto gramaticalmente autorizado (e.g. a vontade é a causa de tal evento corporal; uma idéia é a causa de tal evento corporal, etc.), constitui a mesma espécie de infração lógica que, por exemplo, Sábado está na cama, ou seja, um erro de tipo ou categoria. Em termos espinosanos, julgo, pois, ser plenamente legítimo falar — senão de um “erro categorial” — de um 'erro de gênero'. Mediante a carta 50, é possível também exemplificar o erro de gênero cometido por Descartes como tendo o estatuto de um erro de unidade de medida, como se, por exemplo, alguém perguntasse em quilos qual a distância entre Atenas e Corinto. A crítica de Espinosa ao número e à medida não invalidam a exigência de um cuidado lógico com a distinção entre gêneros; ou seja, os exemplos que estou dando (e,g, quilos/metros) reenviam a conceitos criticados por Espinosa, mas a natureza da diversidade em questão é ratificada pela diferença lógica entre atributos. Reconheço, porém, que a crítica espinosana a Descartes não se esgota nesse aspecto lógico, envolvendo várias outras questões de espessura ontológica. Mas não 
T. Carlson Mark aborda a questão da distinção entre os atributos em termos que - exceto por alguns aspectos que notarei logo a seguir - reforçam esta minha interpretação do conceito de gênero e permitem retomar a caracterização da emendatio e da Medicina Mentis como cuidados lógicos com o pensamento. Para comentar o que sejam os atributos espinosanos, Carlson Mark adota a estratégia de formular a seguinte questão: "quais são os mais inclusivos termos ou categorias (terms or categories) que podem ser usados para descrever o que é (what is)?"196. Ora, depois de considerar que uma "característica compreensiva do ente" (comprehensive characteristic of being) é a existência física no espaço, o comentador assim se exprime:

"Mas nem todo ente (being) está no espaço, o que significa que nem todo ente é físico. Falamos de idéias ou conceitos e eles não entram em relações espaciais. É um uso tão bom da palavra 'é' dizer que 'um pensamento é' quanto dizer que 'um corpo é'; 'ente' pode ser entendido de ambas as maneiras, e uma é tão reveladora do que é o ente (of what being is) quanto a outra (...) Sob o título 'tudo o que é' (everything that is), devemos incluir tanto pensamentos quanto corpos. A forma que Espinosa emprega para comunicar isso é dizer que a Substância possui esses dois atributos (...) 'Ente' é expresso em ambos os casos, mas expresso de diferentes maneiras (ways) (...) Pensamento e extensão são simplesmente duas maneiras pelas quais podemos falar (talk) sobre o que é (what is). Nós pensamos (think) nas coisas como sendo (as being) tanto pensamentos quanto corpos; e essa nos parece a mais fundamental característica (feature) do seu ser (being), qual seja, seu estatuto (status) de pensamento ou corpo físico"197

Dito isso, a consideração da lógica como Medicina Mentis encontra agora amparo conceitual no interior do próprio sistema espinosano e não mais nesta ou naquela influência histórica. Penso aqui na célebre concepção — apresentada justamente no De Emendatione - da "alma agindo segundo certas leis, assim como um autômato espiritual" ${ }^{\text {"198 }}$, ou seja, como uma estrutura de idéias, organizada segundo leis próprias e sendo, portanto, nalguma medida, autônoma. Na caracterização do conceito de automa spirituale, ao lado de certas leges, também sobressai o particípio agentem, indicando que esse conceito não se aplica uma estrutura inerte, em conformidade inclusive com a definição que a Ethica faz das idéias como ações da mente. Assim como a fabrica corporis, esta outra

\footnotetext{
são estas últimas que me interessam no presente contexto, dedicado a caracterizar o De Emendatione como uma Medicina Mentis e como uma lógica.

196 Mark, T.C. (1972) p. 12.

197 Mark, T.C. Op. Cit. p. 12-13

198 TIE $\$ 85$ "animam secundùm certas leges agentem, \& quasi aliquod automa spirituale"
} 
que eu chamarei de fabrica mentis também possui um funcionamento próprio, ou seja, ações regradas, como uma máquina espiritual, ou melhor, como um organismo vivo:

“o autômato possui duas características que instrumento artesanal algum e máquina alguma possuem: tem em si mesmo a fonte de energia para realizar suas operações e dispõe em si mesmo dos meios de auto-regulação e de auto-regeneração para conservar-se na existência e manter suas operações".

Não obstante, como observa Lia Levy, em minucioso estudo sobre a noção de autômato espiritual, isso não quer dizer que a mente humana seja absolutamente autônoma: "o autômato espiritual estará sempre, por pouco que seja, submetido às leis externas que determinam a imaginação" ${ }^{199}$. Assim como um organismo vivo - que realiza trocas com o meio ${ }^{200}$ —, a mente humana não se encontra fechada e indiferente ao que lhe é exterior. A crucial precisão que, no entanto, faz Espinosa, é que esse exterior não equivale a uma faculdade anímica absoluta, como é entendida tradicionalmente a vontade (que viria acrescentar de fora um caráter assertivo e judicativo às idéias), nem equivale ao corpo humano ou aos objetos materiais externos, pensados como princípios causais de ação sobre a mente ${ }^{201}$. O "exterior" aqui admitido é, antes, um outro sistema de idéias, um outro organismo psíquico, do qual a mente humana é apenas uma parte:

“A aplicação da metáfora do autômato para o caso da alma humana começa a tomar forma a partir do momento em que o entendimento e a imaginação são compreendidos como sendo submetidos a certas regras firmes e invariáveis, e que a vontade, enquanto faculdade absolutamente indeterminada de afirmar e negar, é excluída como instância constitutiva do conhecimento, tanto divino quanto humano. Todo conhecimento, seja ele verdadeiro ou falso, deve ser explicado por uma espécie de mecanismo de idéias, e a distinçano entre o verdadeiro e o falso deve reenviar a uma distinção de ordem e de leis (...) Essa distinção, no entanto, exige certos esclarecimentos, pois, conforme a doutrina da Ética, toda idéia na alma é, antes de tudo, uma idéia em Deus (Ethica II, prop. 32), e o entendimento divino não pode comportar senão uma lei. A solução apoia-se na distinção entre a parte e o todo: a alma humana é uma parte do entendimento infinito (Ethica II, prop. 11 corol.) e, enquanto tal, terá necessariamente idéias

199 Cf. Levy, Lia $O$ Autômato Espiritual, p 58. A autora oferece as seguintes passagens da Ethica para amparar essa afirmação: E IV, prop. 4 e corol, E V, prop 20 escol.

200 Veja-se a teoria do indivíduo na pequena física, que comentarei posteriormente .

201 Marilena, trechos sobre o autômato versus o objeto exterior. 
parciais, ou seja, idéias que não podem ser compreendidas apenas pela sua natureza" 202

Através desta última citação, fica bastante clara a articulação, necessária à coerência da doutrina espinosana, entre o traço de autonomia (essencial para a noção de autômato) e o de dependência (essencial para que faça sentido a solicitação de uma Medicina Mentis). A emendatio corresponde, nesses termos, ao trabalho de fortalecer o que há de autônomo no autômato, sem jamais confundir-se com a descabida pretensão de simplesmente suprimir o que nele também há de dependência: terapêutica alguma jamais tornará o sistema finito da mente humana idêntico ao sistema infinito do intelecto divino. No interior do organismo psíquico finito, sob o regime da emendatio contrariamente ao que se passa sob a lógica tradicional - as idéias que o compõem poderão coordenar-se não segundo a ordem e conexão (orde of zamenhangin), externas, das percepções sensoriais, mas sim segundo a ordem e a conexão (ordo et conexio) ${ }^{203}$, internas, das construções (fabricae) intelectuais, isto é, à legibus intellectûs ${ }^{204}$. Muda-se, com isso, de uma "fisiologia mental" preponderantemente passiva para uma outra tão mais ativa quanto mais firme e mais forte puder ser.

\subsection{3) Remate}

Cabe, portanto, abordar o De Emendatione como uma Medicina Mentis e, ao mesmo

202 Levy, Lia $O$ Autômato Espiritual, p. 57 (incisos meus). A seguinte passagem da Carta 32 - na qual Espinosa compara o homem no interior do Universo a um verme vivendo no sangue de outro organismo mais amplo — corrobora a posição de Levy: "No atinente à mente humana, também a considero ser parte da Natureza, pois, de fato, estabeleço dar-se na Natureza também uma potência infinita de pensar, a qual, enquanto infinita, contém objetivamente em si toda a Natureza, e cujos pensamentos procedem do mesmo modo que a Natureza, isto é, que seu ideado. Ademais, estabeleço a mente humana [como] essa mesma potência, não enquanto é infinita e percipiente da Natureza toda, mas finita, a saber, enquanto percebe apenas o corpo humano, e por essa razão estabeleço a mente humana como parte de um intelecto infinito / quòd autem ad Mentem humanam attinet, eam etiam partem Natura esse censeo; nempe quia statuo, dari etiam in naturâ potentiam infinitam cogitandi, qua, quatenus infinita, in se continet totam Naturam objectivè, \& cujus cogitationes procedunt eodem modo, ac Natura, ejus nimirùm ideatum. Deinde Mentem bumanam hanc eandem potentiam statuo, non quatenus infinitam, \& totam Naturam percipientem; sed finitam, nempe quatenus tantùm bumanum Corpus percipit, \& hâc ratione Mentem bumanam partem cujusdam infiniti intellectûs statuo". Essa Carta também fornece elementos para compreender o que Levy chama de "Reversibilidade entre parte e todo: “.”. Aproveito o contexto para propor, então, uma imagem que me parece esclarecedora, a saber, a da mente humana como um órgão do intelecto infinito de Deus, órgão dotado de partes internas que também são seus próprios órgãos, que por sua vez também possuem partes internas, que são suas organelas, etecetera, ad infinitum. Isso é interessante por matizar com as características orgânicas do autômato a teoria do indivíduo, discutida na pequena física da Ethica. Ademais, isso suscita ressonâncias etimológicas com a designação grega para instrumento, qual seja, organon.

$203 \quad$ Ethica II prop7 esc.?

TIE $\S 86$ "operationes illas, à quibus imaginationes producuntur, fieri secundùm alias leges, prorsùs diversas à legibus intellectûs, \& animam circa imaginationem tantùm habere rationem patientis" . 
tempo, como uma lógica que examina e contribui para a execução das regras que dirigem o funcionamento do espírito. E se é verdade que o De Emendatione não fala de regras para a direção do espírito nem tampouco emprega a palavra lógica (aqui trazida a partir da Ethica), é igualmente verdade, porém, que trata "da via pela qual o intelecto é dirigido (dirigitur) de modo ótimo (optime) no verdadeiro conhecimento das coisas"; trata do método, concebido como aquele que mostra de que modo a mente é dirigida (dirigitur) segundo a norma (norman) de uma idéia verdadeira dada ${ }^{205}$; trata da forma dessa idéia (forma veri) e de como ela se perfaz exemplarmente em uma legítima (legitimam) definição; trata da definição como estrutura concernente ao estatuto ontológico de seu objeto (in se ou in alio, que é precisamente a divisão do ente com que têm início os Cogitata); trata das condições (conditiones) ou leis (leges) definicionais, determinadas em função de certas relações de causalidade, leis que, finalmente, presidem aquela definição perfeita ou idéia verdadeira que explica a essência íntima da coisa ao invés de usar em seu lugar alguns próprios.

E - a título de argumento suplementar —, eu também notaria que a noção mesma de método liga-se, mediante uma passagem da Carta 37 (ao médico Bowmeester), à idéia de uma arte de reger os pensamentos ${ }^{206}$ e que - numa oposição que remonta ao Gorgias de Platão, à Metafísica de Aristóteles e ao Corpus hippocraticus ${ }^{207}$ — é contrastada com o acaso (casibus) a que estão submetidos os encontros corporais. Mas, mesmo sem a mediação da Carta 37, essa temática da arte de pensar já se encontrava disponível, tanto nos Cogitata, através da própria expressão Reddenkonst, que se traduz por lógica, quanto no De Emendatione, na equiparação das idéias a instrumentos e construções intelectuais e, de modo geral, em uma analogia estrutural do pensamento com processos técnicos. Juntamente com as noções de corpo, de autômato, de ofício, de instrumento, de ordem e conexão, de lei, e outras que, em geral, remetem a estruturas dinâmicas de funcionamento, essa analogia fabril domina o contexto da lógica espinosana em cujo centro encontram-se a definição genética e as relações entre

\footnotetext{
205

206 TIE $\S 38$ "ostendit, quomodò mens dirigenda sit ad datce verce idece normam."

Carta 37 "aut dari possit Methodus talis, quâ inoffenso pede in prastantissimarum rerum cogitatione sine tedio pergere possimus? an verò, quemadmodum corpora nostra, sic etiam mentes casibus obnoxice sint, ¿o fortunâ magis, quàm arte cogitationes nostrce regantur??

O primeiro Aforismo do Corpus hippocraticus, ainda influente através de uma tradição humanista vigente no século XVI, ensina que "a vida é breve; a arte, longa; o momento oportuno, raro; a experiência, traidora e o juízo, difícil”; Hipócrates, Aphorismoi, I, 1, ed. Jones, Cambridge, 1979, p. 99. apud Chauí, M. A Nervura do Real.
} 
essência e propriedade. Entretanto, há precisões a fazer acerca dessa caracterização da Medicina Mentis como uma ars, isto é, como techné ou kunst. Basta-me, por enquanto, haver legitimado, ao menos em linhas gerais, a tese de que o De Emendatione é uma Medicina Mentis, entendida como uma lógica que, por sua vez, se constitui simultaneamente como contraposta e tributária de uma longa tradição, no interior da qual, interessam-me alguns componentes aristotélicos.

\section{3) Kathartikon : O De EMENDATIONE e a CENSURA KANTIANA À LógiCa dos MODERNOS}

Voltarei em outro momento a discutir essa analogia fabril, essencial, como se vê, para a compreensão do cerne deste ensaio. Apontamentos — suscitados pela associação entre lógica e arte de pensar — sobre as relações entre o De Emendatione e La Logique ou l'Art de Penser, de Arnauld e Nicole, também serão feitos oportunamente. Por ora, desejo prosseguir um pouco mais na determinação do sentido em que o De Emendatione pode ser considerado como uma lógica. Para tanto, recorro inicialmente à formulação concisa de Herman De Djin, em seu artigo "A lógica de Espinosa, ou arte de pensar perfeitamente":

"a busca ética de um bem real requer a obtenção de real conhecimento, o qual, por sua vez, parece impossível sem algum tipo de aperfeiçoamento ou, antes, purificação do intelecto. Portanto, antes de mais nada, é necessário aprender como adquirir um intelecto puro, capaz de desenvolver autonomamente real conhecimento. Uma lógica, no sentido de Espinosa (e usual no século XVII), consiste na indicação da maneira de purificar o intelecto e do modo de pensar verdadeiro, típico desse intelecto purificado e capaz de nos levar a descobrir real conhecimento"

Trata-se aí de uma concepção de lógica marcada por certa tradição humanista, para a qual, além do recuo crítico que examina as condições de possibilidade do conhecimento já formatadas nos próprios instrumentos cognitivos, a lógica deve incluir um efetivo trabalho terapêutico de purificação do intelecto, bem como um compromisso com o modo de aquisição de novos conhecimentos. Essa tradição, "usual no século XVII", se opõe ao que ela própria considera ser a esterilidade formal da silogística aristotélica e busca expandir os limites da lógica, como testemunhará, no século XVIII, 
Kant, ao censurar certos "modernos"208 por haverem, nesse intuito de ampliação, confundido a lógica geral pura, por exemplo, com a lógica geral aplicada ${ }^{209}$. E são algumas considerações sobre essa censura kantiana que farei agora para, como está dito, aprofundar a caracterização do Tractatus de Intellectus Emendatione como uma lógica.

Com efeito, segundo Kant, uma lógica geral aplicada, lidando com "a influência dos sentidos, o jogo da imaginação, as leis da memória, o poder do hábito",210, e também com os obstáculos à atenção, com os estados de dúvida, de escrúpulo, de convicção, etc., dedica-se especialmente à fonte dos preconceitos e à origem do erro, misturandose, pois, com a psicologia e, portanto, com o conhecimento das condições empíricas do exercício do entendimento, afim de examinar como se fomenta ou entrava tal exercício. A lógica geral aplicada estaria para a lógica geral pura assim como a "doutrina das virtudes" (que estuda as condições variáveis da ação moral) está para a "moral pura" (que estuda apenas a forma dessa ação), servindo tal comparação para reafirmar que a lógica geral aplicada "nunca pode constituir uma ciência verdadeira e demonstrada"211. Mesmo assim, enquanto lógica geral, ela não faz distinções de objeto - não é o conjunto de regras para pensar sobre o objeto desta ou daquela ciência - mas configura-se, por causa de sua inserção empírica, como uma representação do uso geral do entendimento comum "in concreto" 212 . Esta lógica geral aplicada não é, pois, como a lógica geral pura, um estrito cânone mas, antes, um "kathartikon",13 do entendimento.

Ora, não só por conter muitos dos temas acima elencados ou por falar de uma

208 "Na verdade, se alguns modernos pensaram alargá-la [a lógica], nela inserindo capítulos quer de psicologia, referentes às diferentes capacidades de conhecimento (imaginação, presença de espírito), quer metafísicos, respeitantes à origem do conhecimento ou às diversas espécies de evidência, consoante a diversidade dos objetos (idealismo, ceticismo, etc.), quer antropológicos, relativos aos preconceitos (Vorurteilen) (suas causas e seus remédios), provém isso do seu desconhecimento da natureza peculiar desta ciência” Kant CRP B VIII.

209 Sob esta rubrica reaparecem os itens enumerados na nota anterior sob aqueles "capítulos" de psicologia, metafísica e antropologia, agora no contexto da Introdução à Segunda Parte da Doutrina Transcendental do Elementos.

$\begin{array}{ll}210 & \text { Kant } C R P \text { B } 77 \\ 211 & \text { Kant } C R P \text { B 79 } \\ 212 & \text { Kant } C R P \text { B 78 }\end{array}$

$213 \quad$ Kant CRP B 78 / Confira-se também Kant, I. Manual dos cursos de lógica Geral. Trad. Apresentação e notas, Fausto Castilho. Campinas, Editora Unicamp, 2003. AK 18, ed. Gruyter: "Na Lógica Pura, separamos o intelecto das outras faculdades do ânimo e o consideramos isolado em sua operação. A Lógica Aplicada considera o intelecto, na medida em que se mistura com as outras forças do ânimo que influem em suas ações e lhe impõem um desvio de direção, de maneira que já não procede segundo as leis que ele mesmo considera corretas. A Lógica Aplicada não deveria chamar-se propriamente Lógica. Trata-se de uma psicologia (...) e dela se pode aprender o que promove o uso do intelecto, os meios de ajuda-lo e os remédios contra as falhas lógicas e os erro. Propedêutica, contudo, ela não é". 
necessária expurgatio do intelecto - que praticamente traduz o grego katharsis ${ }^{214}$ — o De Emendatione parece cair sob essa caracterização de uma lógica geral aplicada feita por Kant. Afinal, no que diz respeito ao recuo relativo ao conhecimento deste ou daquele objeto em particular, o tratado também reconhece a si mesmo como distinto do sistema da Philosophia propriamente dito ${ }^{215}$, cuidando, pois, do que deve ser feito ante omnia e assumindo, nessa medida, algo do caráter de uma lógica geral, isto é, de um conhecimento das próprias potências de pensar enquanto tais:

"o método deve falar necessariamente (loqui) do raciocínio (de ratiocinatione) e da intelecção (de intellectione); isto é, o método não é o próprio (ipsum) raciocinar para inteligir as causa das coisas, e muito menos é o inteligir ( $\tau$ intelligere) as causas das coisas, mas é inteligir o que seja a idéia verdadeira, distinguindo-a das demais percepções, investigando sua natureza, afim de que conheçamos nossa potência de inteligir e coibamos a mente de tal maneira que, tudo aquilo que é a inteligir, [ela] intelija segundo aquela norma (norma), trazendo como auxílio certas regras (regulas) e também fazendo com que a mente não se fatigue com inutilidades". 216

Mas, no que diz respeito ao que Kant chama de "aplicação", algo parece diferir do simples envolvimento com a psicologia empírica. O ponto que me parece central é que o método espinosano, por ser cognitionem reflexivam ou ideam idece, ${ }^{217}$ supõe uma idéia verdadeira dada, efetivamente pensada, de modo que a reflexão sobre a forma da idéia se faça inseparável da presença em ato de uma idéia singular que seja o conteúdo dessa mesma reflexão: “como não há idéia da idéia a não ser que primeiro haja a idéia, segue-

$214 \kappa \alpha \theta \alpha \rho \sigma ı s,($ katharsis): 1 purificação 2 purgação em sentido médico. Termo derivado do verbo к $\alpha \theta \alpha \iota \omega$, (kathairó) cujo sentido é: purificar, 1 limpar, lavar 2 purificar em sentido religioso 3 purgar. A palavra que Kant emprega é, em alemão, Kathartikon; do adjetivo grego: к $\alpha \propto \alpha \rho \tau \iota \kappa o s$ (kathartikos): próprio a purificar. Para verificar o equivalente terminológico latino, veja-se, por exemplo, o seguinte trecho da tradução de Poetica de Aristóteles para o Latim (6,1449b 24ss): "É, com efeito, a tragédia imitação de uma ação ( $\pi \rho \alpha \xi \varepsilon \omega s /$ actionis) (...), procedendo por atores ( $\rho \rho \omega v \tau \omega v /$ agentibus) e não por narração ( $\alpha \pi \alpha \gamma \gamma \varepsilon \lambda \iota \alpha$ s /enarrationem) e que, mediante compaixão e medo, leva a cabo a

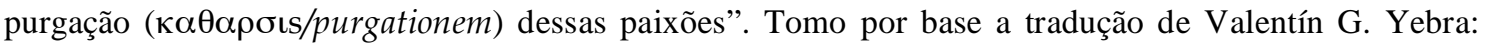
Poética de Aristóteles, Madrid, Gredos, 1974.

215 Cf TIE, notas k, $1(\$ 31)$, n $(\$ 34)$, o $(\$ 36)$, z $(\$ 76)$ - uso aqui a marcação de notas apresentada por Rousset (1992).

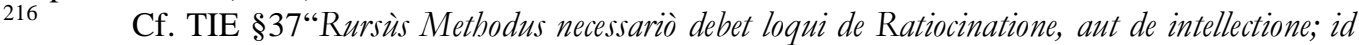
est, Methodus non est ipsum ratiocinari ad intelligendum causas rerum, \&o multò minùs est to intelligere causas rerum; sed est intelligere, quid sit vera idea, eam à cateris perceptionibus distinguendo, ejusque naturam investigando, ut inde nostram intelligendi potentiam noscamus, \& mentem ità cobibeamus, ut ad illam normam omnia intelligat, qua sunt intelligenda; tradendo, tanquam auxilia, certas regulas, \&o etiam faciendo, ne mens inutilibus defatigetur".

$217 \quad$ TIE $§ 38$ 
se que não há método a não ser que haja primeiramente uma idéia"218. A efetiva execução do ato de pensar está pressuposta no conceito de idéia dada. O método não consiste em cotejar as idéias, depois de adquiridas (post acquisitionem idearum) ${ }^{219}$, com um sistema formal canônico que, enquanto tal, só poderia fornecer parâmetros negativos ou condições sine qua non - necessárias mas não suficientes ${ }^{220}$ — da verdade; ele consiste, antes, "na via pela qual as idéias são procuradas na devida ordem"221. Dito em outras palavras: não é o método que primeiramente fornece a norma para o exercício do pensamento, é esse exercício efetivo que fornece para o método uma norma que, então já exercida, é norma e instância de si mesma simultaneamente. A norma da idéia verdadeira dada é uma condição imanente à presença em ato da idéia que ela condiciona como seu objeto e não uma condição necessária, abstrata e separada, forma vazia de objetos meramente possíveis. Assim, não se separam, na lógica espinosana, o "como devemos pensar de direito" (norma ideae verae) e o "como pensamos de fato" (datae), que Kant, de sua parte, identifica respectivamente ao objeto da lógica geral pura e ao objeto da psicologia:

$218 \quad$ TIE $\S 38$

219 TIE §36: "quòd vera non est Methodus signum veritatis quarere post acquisitionem idearum,"

220 Cf. Brunschvicg, L. (1893) p 453-467: "O método não pode preceder a aquisição das idéias, como se ele fosse uma condição necessária”, p. / Cf. Kant, I. Manual dos cursos de lógica Geral AK 51, ed. Gruyter: "Para se alcançar a verdade objetiva, esses critérios universais formais não são de fato suficientes, mas têm de ser vistos como conditio sine qua non dessa verdade. Pois a questão sobre se o conhecimento concorda com o objeto deve ser precedida da questão sobre se ele concorda consigo mesmo (segundo a forma). E este é o assunto da lógica (...). Exige-se, pois, da verdade lógica de um conhecimento: em primeiro lugar, que ele seja logicamente possível, isto é, que não se contradiga. Esse sinal distintivo da verdade lógica interna é, porém, apenas negativo: um conhecimento que se contradiz é certamente falso, mas não é porque não se contradiz que um conhecimento é sempre verdadeiro". Kant, na seqüência desse mesmo trecho, afirma a existência de um segundo critério de verdade lógica mas, agora, externa, a saber, as relações entre antecedentes e conseqüentes: quando um conseqüente falso é inferido de um conhecimento, este último deve ser falso, mas não se segue que se o conseqüente é verdadeiro o antecedente também o seja, pois de um antecedente falso podem ser tirados conseqüentes verdadeiros (por exemplo, do sistema astronômico ptolomaico, que é falso, podemos fazer predições certeiras sobre as posições dos orbes celestes). Esse primeiro critério externo consiste, pois, numa inferência no modus tollens, que continua provendo um critério da verdade meramente necessário ou negativo (sine qua non). Um critério positivo aparece apenas com o modus ponens: "se todos os conseqüentes de um conhecimento são verdadeiros, então o próprio conhecimento é verdadeiro, pois se houvesse algo de falso no conhecimento, deveria também ocorrer um conseqüente falso". Entretanto, Kant sublinha que há dificuldade para que sejam conhecidos absolutamente todos os conseqüentes, de sorte que, mesmo sendo possível inferir um fundamento do qual procedem esses conseqüentes, ele permanecerá indeterminado, incompleto, proporcionando um conhecimento "provável e hipoteticamente verdadeiro, segundo a pressuposição de que, onde muitos conseqüentes são verdadeiros, os restantes podem ser também todos verdadeiros". O interesse de Espinosa pelo tema das hipóteses científicas, como veremos, são índices de seu esforço na obtenção de um critério positivo da verdade. Por ora, explorarei outros aspectos do método espinosano que enriquecem sua caracterização nesse contexto da busca "moderna" ou seiscentista pela suficiência e pela positividade que coincide com a busca do que chamam "uma verdadeira lógica" Cf.Homero.

221 TIE §36: "sed quòd vera Methodus est via, ut ipsa veritas, aut essentice objectiva rerum, aut idea (omnia illa idem significant) debito ordine quarantur" 
“Alguns lógicos pressupõem princípios psicológicos na Lógica. Mas introduzir semelhantes princípios na Lógica é precisamente tão absurdo quanto buscar a Moral na vida. Se tirássemos nossos princípios da psicologia, isto é, das observações sobre nosso intelecto, veríamos apenas como o pensamento procede e como ele é sob uma variedade de impedimentos e condições subjetivos, o que nos levaria ao conhecimento de leis meramente contingentes. Mas, na Lógica, não se trata de regras contingentes, mas necessárias, não de como pensamos, mas sim de como devemos pensar. (...) Na lógica não queremos saber como o intelecto é e pensa e como até agora procedeu ao pensar, mas como deveria proceder. Ela deve nos ensinar o uso correto do intelecto que concorda consigo mesmo"

Ora, tirando proveito, primeiramente, da correlação estabelecida pelo próprio Kant entre Moral e vida, eu diria então que a lógica espinosana porta-se perante o funcionamento efetivo do pensamento assim como sua ética porta-se diante da vida prática dos seres humanos, testemunhada pela experiência. Tenho aqui em mente os bem conhecidos parágrafos iniciais do Tractatus-Politicus, nos quais Espinosa critica o moralismo dos filósofos acusando-os de não haverem escrito uma ética mas, antes, quimeras e sátiras, louvando de muitos modos uma natureza humana que não existe em parte alguma (bumanam naturam, quae nullibi est, multis modis laudare) e lacerando com seus discursos aquela que realmente existe (et eam, quae reverâ est, dictis lacessere). Prescrevendo ou proscrevendo sem descrever, os filósofos moralistas antepõem o dever ser ao ser e concebem os homens não como são, mas como eles próprios gostariam que fossem (Homines namque, non ut sunt, sed, ut eosdem esse vellent, concipiunt), nada concebendo, pois, sobre a vida política que pudesse ser reconvocado ao uso (quae possit ad usum revocari). Essa atitude dos moralistas é caracterizada por uma disjunção entre teoria e prática, entre o direito e o fato: "de todas as ciências que têm um uso (quae usum babent) a politica é crida como a aquela em que a teoria mais discrepa da prática (maximè Theoria ab ipsius Praxi discrepare), e para reger (regenda) a República ninguém é estimado como menos apto do que o teórico, ou seja, o filósofo (Theoretici, sen Philosoph)" ${ }^{, 223}$. Os políticos, em contrapartida, escreveram com mais felicidade do que os filósofos sobre a vida prática, pois tiveram a experiência como mestra (experentiam magistram habuerunt). Todavia, esses

\footnotetext{
$222 \quad$ Kant, I. Manual dos cursos de lógica Geral AK 14, ed. Gruyter.

TP I §1: "Cùm igitur omnium scientiarum, quae usum habent, tum maximè Politices Theoria ab ipsius Praxi discrepare creditur, \& regendae Reipublicae nulli minùs idonei aestimantur, quàm Theoretici, seu Philosophi"
} 
mesmos políticos, embora não desconsiderem a experiência, exercem uma arte que homens guiados mais pelo medo do que pela razão soem exercer (artibus (...) quas homines, magis metu, quàm ratione ducti, exercere solent), o que conota uma evidente inadequação.

Nem deixar-se levar pelo pensamento que ignora a experiência, nem seguir apenas a experiência independentemente da razão, o que Espinosa propõe é "demonstrar por uma razão certa e indubitável aquilo que convém otimamente com a prática" (ea, quae cum praxi optimè conveniunt, certâ, \& indubitatâ ratione demonstrare ${ }^{224}$. Aliás, é essa integração entre direito (certâ, \& indubitatâ ratione) e fato (praxi) que leva Espinosa a adotar, com a mesma liberdade de ânimo presente nas matemáticas, o princípio de não rir nem deplorar ou detestar, mas sim inteligir as ações humanas (bumanas actiones non ridere, non lugere, neque detestari, sed intelligere). Como veremos no próximo capítulo deste ensaio, tal referência à matemática, num contexto metodológico de recusa à unilateralidade quer do fato quer do direito, não é gratuita: o que está no horizonte epistêmico da abordagem que o TP faz do comportamento humano sob as paixões é a norma da verdade trazida pela geometria genética. Mas, por enquanto, nos limites da presente discussão, basta dizer que, para Espinosa, o homem, tendo por um lado o intelecto e sua norma, e por outro, a experiência factual, deve ir ao encontro da natureza, para ser por esta ensinado, é certo, mas não na qualidade de um aluno que aceita tudo o que o mestre afirma, nem tampouco na qualidade de um juiz, que obriga as testemunhas a responder aos quesitos que lhes impõe, mas sim — veremos agora - na condição de um historiador da natureza, intérprete das ações e pensamentos humanos que em seu seio transcorrem.

Assim, se está correta esta interpretação de como a analogia entre ética e lógica se estabelece no sistema de Espinosa, será possível encontrar, então, na concepção espinosana da arte de reger não a República mas os pensamentos, essa mesma tendência a não separar o fato do direito, a prática da teoria, o ser do dever ser. E isso pode ser efetivamente verificado, por exemplo, na maneira pela qual o método, segundo o $D e$ Emendatione, deve partir justamente de como o intelecto é e pensa de fato e de como até agora procedeu ao pensar:

"exige a ordem, que naturalmente temos, que eu resuma todos

TP I, §4. 
os modos de perceber que tive até aqui (quos bucusque babui) para afirmar ou negar independentemente de dúvidas, a fim de que eleja o ótimo e, simultaneamente, comece a conhecer minhas forças e natureza que desejo aperfeiçoar",225

Ora, são patentes para o leitor do De Emendatione as exortações feitas por Espinosa. Depois que conhecemos esse méto do, vimos em quarto lugar que ele será perfeitíssimo quando tivermos a idéia do Ser perfeitíssimo. Portanto, desde o começo se observará principalmente que devemos chegar o mais cedo possível ao conhecimento desse Ser: "Quanto à ordem, porém, e para que todas as nossas percepções se coordenem e se unam, exige -se que, o mais cedo que se possa fazer e que a Razão postula, investiguemos se existe algum ser (e ao mesmo tempo qual é) que seja a causa de todas as coisas, a fim de que sua essência objetiva seja também a causa de todas as nossas idéias. Aí então nossa mente, como dissemos, reproduzirá a Natureza no máximo grau possível, pois terá objetivamente tanto sua essência, como sua ordem e união".

Ora, isso que o De Emendatione exibe performativamente em sua démarche mas apenas sugere enunciativamente através da expressão "ordem que naturalmente temos", a Carta 37, por sua vez, explicita, prescritivamente, como sendo um expediente metodológico muito preciso, de origem baconiana, que Espinosa denomina de história. No âmbito lógico da direção do pensamento, Espinosa então propõe que o método tenha por base "uma pequena história da mente, ou seja, das percepções (bistoriola mentis sive perceptionum). E é de notar que, na mesma carta, Espinosa mostra saber perfeitamente que se trata de algo distinto de um conhecimento dedutivo da mente a partir da causa primeira, mas sem que isso implique qualquer insuficiência dessa bistoriola para fundar suficientemente a posse de um método:

"para que o verdadeiro método seja adquirido (ut acquiratur), é necessário, antes de tudo (necesse est ante omnia), distinguir entre intelecto e imaginação, ou seja, entre as verdadeiras idéias e as demais (distinguere inter intellectum, \& imaginationem, sive inter veras ideas, \& reliquas) (...) Para entender isso (Ad haec intelligendum), ao menos o quanto exige o método (saltem quoàd Methodus exigit), não é mister conhecer a natureza da mente por sua causa primeira (non est opus naturam mentis per primam ejus causam cognoscere), mas é suficiente compor sistematicamente uma pequena história da mente, isto é, das percepções (sed sufficit mentis, sive

225 TIE §18: "exigit ordo, quem naturaliter habemus, ut hîc resumam omnes modos percipiendi, quos bucusque habui ad aliquid indubiè affirmandum, vel negandum, quò omnium optimum eligam, \& simul meas vires, \& naturam, quam perficere cupio, noscere incipiam" 
perceptionum historiolam concinnare), daquele modo como ensina Verulâmio.",226

Ademais, como já foi notado por vários outros comentadores, é nessa mesma acepção baconiana que o termo historia também comparece no capítulo VII do Tractatus Theologico-Politicus, na dissertação sobre o método de interpretação das Escrituras, quando então "é tomado no sentido corrente na época, isto é, como recolha de elementos de onde extrair os princípios com base nos quais será feita a dedução científica". Destarte, a bistoriola mentis prescrita pela Carta 37 e empreendida pela medicina mentis no De Emendatione, deve agora ser caracterizada, via TTP VII, como sendo também uma sincera bistoria:

"O método de interpretar as Escrituras não difere em nada do método de interpretar a Natureza; e concorda (conveni $[t]$ ) até inteiramente com ele. $\mathrm{Na}$ realidade, assim como o método para interpretar a Natureza consiste em compor sistematicamente uma história da Natureza (concinanda historia naturce) e daí concluir, como a partir de dados certos (utpote ex certis datis), as definições das coisas naturais (rerum naturalium definitiones), assim também, para interpretar as Escrituras, é necessário confeccionar a sua história sincera (sinceram historiam adornare) e, depois, a partir dela como que de dados e princípios certos (ex ea tamquam ex certis datis et principiis), concluir, como legítima consequiência (legitimis consequentiis concludere), o pensamento de seus autores (mentem authorum). Deste modo, quer dizer, se na interpretação das Escrituras e na discussão de seu conteúdo (de rebus in quae in eandem continentur) não se admitirem outros princípios nem outros dados (nulla alia principia, neque data) alem dos que se podem extrair das próprias Escrituras e de sua história (ex ipsa Scriptura ejusque historia depromuntur), estaremos a proceder sem perigo de errar e poderemos discutir com tanta segurança as coisas que ultrapassam nossa compreensão como aquelas que conhecemos pela luz natural" 227 .

Analogamente ao que se passa no plano ético, a sincera historia é aqui um expediente necessário para que "não abracemos, arrebatados por um cego ímpeto, o que

226 EP 37; “"ut acquiratur, necesse est ante omnia distinguere inter intellectum, \& imaginationem, sive inter veras ideas, \& reliquas, nempe fictas, falsas, dubias, \& absolutè omnes, qua à solâ memoriâ dependent. Ad hac intelligendum, saltem quoàd Methodus exigit, non est opus naturam mentis per primam ejus causam cognoscere, sed sufficit mentis, sive perceptionum historiolam concinnare modo illo, quo Verulamius docef' (S.O. IV $188,19 \mathrm{ss})$.

S.O. III, p 98,18. Uso, como uma primeira base para citação, a tradução de Diogo Pires Aurélio (1988) - embora faça algumas modificações em função de consultas ao texto latino e das ênfases que ele permite de acordo com o contexto. 
quer que nos seja imposto, mas somente isso que é certo e indubitável",228; certeza e indubitabilidade correspondendo, então, não aos atributos homônimos das demonstrações feitas a partir de causas primeiras, mas sim à ubiqüidade, ao caráter ex professo e à consistência ou não ambigüidade do que foi recolhido no estrito limite da fonte historiada ${ }^{229}$. E se uma identidade metodológica é afirmada mesmo na interpretação de fontes tão diferentes quanto a Natureza e as Escrituras, é porque, em ambos os casos, tal identidade consiste em um tratamento igualmente desigual dos desiguais e não em um método que seria como uma única e mesma chave a abrir — qual chave de ladrões ${ }^{230}$ — toda e qualquer porta, violando seja a especificidade dos livros sagrados, seja a do livro da natureza (ou melhor, em termos propriamente espinosanos, a especificidade do discurso imaginativo sobre Deus e a dos verdadeiros

228 S.O. III p. 102, 11: "ut ne caco impetu correpti, quicquid nobis obtruditur, sed tantum id, quod certum \& indubitatum est, amplectamur". É interessante notar que o substantivo correptio, onis - correlato do verbo corripio, que aqui se traduz, seguindo Pires Aurélio, por arrebatar — traz consigo a idéia de passividade e, especificamente, de afecção de uma doença. Complementarmente, o verbo, obtrudo, ere, indica a imposição sob a qual se estabelece tal passividade. Isso se afigura interessante por reforçar a semelhança entre as dificuldades vividas durante o esforço de interpretar corretamente as escrituras e o esforço de inquirir, em meio à trama de acontecimentos da vida comum, acerca de um verdadeiro bem.

229 No sentido de caracterizar essas certeza e indubitabilidade, são úteis os exemplos que Espinosa apresenta do que seja a doctrina contida nas Escrituras: "que existe um Deus único e onipotente, só o qual é a ser adorado, que cuida de todos, que quer bem sobretudo a todos os que o adoram e amam ao próximo como a si mesmos, etc. Esses e semelhantes [ensinamentos], digo eu, ubiquamente as Escrituras ensinam tão clara e tão expressamente que jamais houve alguém que ambigüizasse seu sentido acerca deles /Exempli gratia, quod Deus unicus \& omnipotens existit, qui solus est adorandus, \& qui omnes curat, eosque supra omnes diligit, qui ipsum adorant, \& proximum tanquam semet ipsos amant \&c. Haec \& similia, inquam, Scriptura ubique tam clare, tamque expresse docet, ut nullus unquam fuerit, qui de ejus sensu circa baec ambegerif' (S.O. III p. 102, 32). Espinosa é enfático ao opor a uniformidade das recomendações dos profetas, por cuja recolha chega-se a algo certo e indubitável, ao inconsistente agregado de opiniões heteróclitas em que se configura a recolha — também pela história — de suas afirmações concernentes ao que seja Deus, a como ele vê todas as coisas e por elas providencia, etc.: "essas [coisas] e semelhantes, as Escrituras não ensinam declaradamente e como doutrina eterna: mas, ao contrário, já mostramos os próprios Profetas não terem convido acerca desses assuntos / hac et similia Scriptura ex professo, \& tanquam aeternam doctrinam non docet: Sed contrà Prophetas ipsos circa haec non convenisse jam supra osdendimus" (S.O. III p. 103,1).

230 É Bacon quem sugere a imagem da "chave", afirmando que "na boa e bem instituída história natural estão as chaves das ciências e das obras", in Historia naturalis et experimentalis ad condendam philosofiam, Works III, 201, apud Santiago, H. Espinosa e o cartesianismo p. 191. A expressão "chave de ladrões" foi aqui emprestada de Negri (in "Entrevista com Toni Negri", Contrapoder. Una introductión, Ediciones de Mano, Buenos Aires, 2001 apud Gainza, Mariana (2007) p. 11. O contexto em que Negri emprega a referida expressão é aqui relevante por relacionar-se justamente com a crítica a um método (no caso, o método dialético) que, malgrado sua própria vocação, teria acabado por converter-se - dialeticamente!! — em seu contrario, enrijecendo-se em uma forma abstrata. Nas palavras de Mariana de Gainza: "A subordinação das tentativas de compreensão da práxis humana à abstração e à formalidade de um princípio explicativo único, válido para toda e qualquer realidade, traía as exigências de seu objeto multiforme e vital, sempre exercitando novas modalidades de autoconstituição. Ou como diz Antônio Negri com uma fórmula concisa: 'por que a dialética é falsa? Porque é uma chave que abre todas as portas; então é uma chave de ladrões"'. Ora, no contexto seiscentista do método de interpretação das Escrituras, um fenômeno semelhante de reversão dialética de um método em seu contrario poderia ser dado através da obra de L. Meyer, Philosophia S. Scriptura Interpres, referida logo a seguir. 
códices em que as leis da natureza estão escritas como em coisas fixas e eternas ${ }^{231}$ ).

Aquilo que uma sincera historia prescreve é, pois, a norma de uma análise imanente dos data, que pode ser contrastada, por exemplo, ao que empreende obra de L. Meyer, Philosophia S. Scripturce Interpres, na qual, como ensina P-F. Moreau:

"[Meyer] propõe uma solução de estilo cartesiano: ler o texto sagrado à luz da razão; e como a razão é a filosofia de Descartes, deduz-se que tudo que, na Escrituras, parece não estar conforme a luz natural deve ser banido delas como má interpretação. Trata-se aí, evidentemente, de um cartesianismo bastante heterodoxo, mas que é interessante, sobretudo, como exemplo de um racionalismo que nada deixa subsistir à parte da razão",232

Ora, como já tive a ocasião de notar em estudos anteriores, "para Espinosa, um racionalismo tão unilateral e imediatamente aplicado que, mesmo ao interpretar as Escrituras, nada deixa subsistir à parte da razão seria, na verdade, irracional, o que é uma observação que traz problemas para a empobrecida caricatura que muitas vezes é feita do racionalismo absoluto espinosano" ${ }^{233}$. Se Espinosa afirma uma unidade metodológica é porque sua regra universal de interpretação (regula universalis interpretandi), bem ao contrário de uma regra universal abstrata, é a própria exigência de que o conhecimento "de quase tudo o que vem nas Escrituras, deva investigar-se unicamente nas próprias Escrituras (ab ipsa Scriptura sola), assim como (sicut), o conhecimento da Natureza se investiga na própria Natureza (ab ipsa Natura)". Pautada pela norma estrutural que é "ab ipsa (...) sicut ab ipsa (...)", a bistoria sincera funda uma unidade metodológica de segunda ordem (sicut), e a disciplina e o rigor que a aparentemente ingênua ordem história então manifesta é sua exigência, em todos os casos, de que quaisquer procedimentos ulteriores que viessem a cursá-la - como, por exemplo, um procedimento analítico que reconduzisse o dado inicial à sua causa, ou um procedimento sintético que, uma vez atingida a causa, reconstruísse o dado originário a partir desta última — só poderiam operar sobre esses mesmos elementos constatados,

231 A expressão "Códices Sagrados" é empregada, no TTP, como sinônimo de "Sagradas Escrituras” [Cf. S.O. III p.93,24; p. 106,13]. No TIE, a noção de códice, que remete à célebre metáfora galileana do Livro da Natureza, aparece no $\$ 101$ nos seguintes termos: " [intimâ essentiâ rerum] verò tantùm est petenda à fixis, atque aternis rebus, \& simul à legibus in ïs rebus, tanquam in suis veris codicibus, inscriptis, secundùm quas omnia singularia, \& fiunt, \& ordinantur l."

232 Moreau, P-F. (1992) p 119-31

233 Rezende, C. "Idéia verdadeira e História", in Cadernos Espinosanos II (2), São Paulo,

1997, p. 131. 
coligidos e descritos pela história, sem que fosse lícito o recurso a dados adicionais ou princípios provenientes de outras bases (por exemplo, da Escrituras, na interpretação da Natureza, ou da Natureza, na interpretação das Escrituras):

"quando investigamos o sentido (sensum) das Escrituras, há que evitar a todo custo deixarmo-nos influenciar pelo nosso raciocínio (para já não falar dos nossos preconceitos) porquanto ele se assenta nos princípios do conhecimento natural (...) Mesmo quando o sentido literal repugna à luz natural, devemos mantê-lo, a não ser que esteja em flagrante contradição com os princípios e os fundamentos tirados da história das Escrituras" ${ }^{234}$.

O método não se fragmenta porque preside, antes de mais nada, uma investigação do sentido do datum, ou seja, — como a letra mesma do texto já explicita - porque é um método de interpretar (interpretandi). A bistoria fornece, por um lado, o fundamento ou as fontes materiais de um trabalho caracterizado como interpretação de sentidos, e não se dá em chave probatória ou demonstrativa. Tanto na história da Escrituras e na história da Natureza, comentadas no TTP, quanto na história da mente, preconizada pela Carta 37 e empreendida no De Emendatione, não se trata ainda de demonstrar mas tão somente de mostrar certos conteúdos. Por outro lado, essas histórias não fornecem tais conteúdos de forma absolutamente paratática, pois exigem — como se vê, por exemplo, na exposição dos modos de perceber, no De Emendatione que a descrição inicial dos dados se faça sob a forma de um resumo completo $^{235}$, produzindo inclusive uma enumeração: "si accurate attendo, possunt omnes ad quatuor potissimum reduci" ${ }^{236}$. A ordem que naturalmente temos é, pois, aquela em que, para o conhecimento de algo desconhecido, o primeiro movimento é a realização de um inventário, isto é, um expediente que, na medida mesma em que encontra uma multiplicidade dispersa e indiferenciada, busca encontrar também alguma unidade, ainda que seja uma unidade de fato.

Portanto, isso que, para Kant, é conhecer apenas como o pensamento procede e não como, de direito, deve pensar, o De Emendatione chama de ordo quem naturaliter habemus", a Carta 37 denomina como historiola mentis, e o TTP, por sua vez, explicita como sendo uma sinceram historiam, isto é, coleta e inventário de materiais empíricos que,

\footnotetext{
${ }^{234}$ S.O. III 100,8-16

$\S 18$ : "exigit ordo (...) ut hic resumam omnes"

$236 \S 19$ : "se atento acuradamente, podem ser reduzidos principalmente a quatro"
} 
constituindo um sentido, orientam a mente a buscar, no estrito limite dos dados coligidos e inventariados, as definições e os primeiros princípios das coisas a conhecer $^{237}$. O qualificativo "sincero" aplicado a essa história corresponde a "uma demorada, solícita e instante dedicação à experiência, à matéria e ao fluxo das coisas particulares" ${ }^{238}$, bem conhecida do leitor da época ${ }^{239}$, que facilmente se recordaria, através da referência de Espinosa a Bacon, das relações, presentes no Novum Organum, entre a composição de uma bistoriola e certas exigências metodológicas das práticas médicas, sobretudo em investigações anatomo-fisiológicas:

"Efetivamente construímos no intelecto humano um modelo verdadeiro do mundo (verum exemplar mundi), tal qual foi descoberto e não qual dita a alguém sua própria razão. Porém, isso não é possível levar a efeito, sem uma prévia e diligentíssima dissecção e anatomia do mundo (mundi dissectione atque anatomia). Por isso, decidimos expulsar todas essas imagens ineptas e simiescas que a fantasia humana infundiu nos vários sistemas filosóficos. Saibam os homens, como já antes dissemos, a imensa distância que separa os ídolos da mente humana das idéias da mente divina. Aqueles, de fato, nada mais são que abstrações arbitrárias; estas, ao contrário, são as verdadeiras marcas do Criador sobre as criaturas, gravadas e determinadas sobre a matéria, através de linhas exatas e delicadas" 240

Outros comentadores também notaram que trata-se aí de um "registro de longa e venerável tradição", na qual se encontra, por exemplo, a História dos Animais, de Aristóteles. Mas, de minha parte, considero que - mesmo sem dispor de mediações que justificassem historicamente a aproximação - a origem mais remota do próprio sentido baconiano da historia baconiana e, portanto, da historiola mentis proposta por Espinosa poderia, se referido sobretudo à caracterização de história feita por Aristóteles

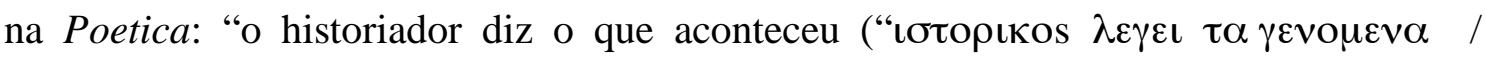

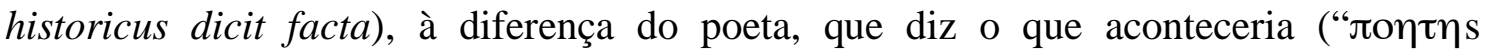

237

238

239

Cf. Marilena Chaui (1999), volume de notas, bibliografia e índices, nota 21, p.138.

Bacon, Novum Organum, Aforismo 124.

"Ao homem letrado do XVII a par dos recentes desenvolvimentos do saber de seu tempo, a palavra história traz no bojo uma indelével ressonância baconiana. A difusão das obras, a repetição verbatim de trechos muita vez sem a designação da fonte, fizeram do legado do LordeChanceler uma espécie de patrimônio comum da época; sobretudo na Holanda, onde sua difusão foi rápida e favorecida pelo ambiente renovador.Não admira, pois, o lugar paradigmático de Bacon no que concerne à significação da história e de seus métodos; seu nome de tal maneira liga-se a uma empresa do gênero que Descartes e Espinosa, ambos, podem falar de uma história verulâmia como que a servirem-se de um lugar de especificação prontamente entendido por quem quer que seja (...)"; Santiago, H. ('), p. 190. Cf. a nota 5 desta mesma página: Descartes a Mersenne, [10-5-1632], AT I, 251, 16-18: 'Escrever a história das aparências celestes segundo o método de Verulâmio'.

240 Bacon, Novum Organum, Aforismo 124: “.”, 


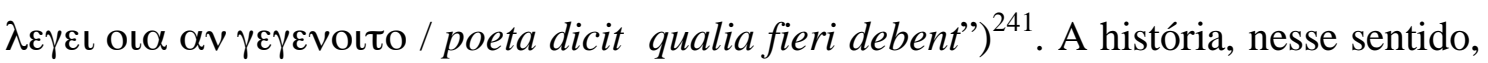
diz respeito ao que efetivamente se passou com algo ou alguém numa situação singular, admitindo, portanto, a reunião de elementos apenas pela contiguidade espacial ou temporal, mas sempre subordinado à exigência de que esses elementos possam ser atribuídos a um mesmo objeto. Este é o tipo de unidade que lhe compete: a de ser circa unum $(\pi \varepsilon \rho \iota \varepsilon v \alpha)^{242}$, por exemplo, a história de Hércules, ou de Alcibíades. E, assim, a história corresponde a um nível ainda não propriamente filosófico ${ }^{243}$. Já à elaboração poética são feitas exigências tanto de verossimilhança quanto de necessidade e unidade internas: ela não é apenas acerca de um, ela própria há de ser una, ou seja, há de reproduzir uma ação una e inteira, na qual as partes dos acontecimentos se ordenem de tal forma que, se se transpõe ou suprime uma parte, se altera e rearranja o todo, "pois aquilo cuja presença ou ausência não altera o todo, não é parte do todo"244. A elaboração poética se dá, pois, sob a égide da totalidade determinada pela estrutura começo-meio-fim $^{245}$. Assim, em oposição à unidade e à totalidade da elaboração poética, a história estabelece uma unidade e uma totalidade factuais

E essa disciplina do concreto pode ser, portanto - mediante as supra referidas equações - aplicada não só ao contexto do método como "norma da idéia verdadeira dada" no TIE (exemplar mundi), como também no contexto da analogia que Kant faz entre a lógica e a moral.

A expressão "datce verce idec normam"246 inclui, como elemento formal da própria norma, a determinação de que ela esteja instanciada, o que também é corroborado pelo fato de que Espinosa não fala aí de "norma da verdade" mas de "norma da idéia verdadeira", ou de "forma do verdadeiro", mantendo a verdade, nesse contexto, sempre na condição de adjetivo e não de substantivo. Assim, um tal método, conquanto seja caracterizado como "conhecimento do intelecto puro, de sua natureza e de suas leis" 247 ,

\footnotetext{
241 Poética 1451 b 1-5. A tradução adotada foi a de Aristóteles, Poética. Trad V.G. Yebra. Edição trilingüe; Madrid, Gredos Editorial, 1974.

$242 \quad$ Aristóteles, Poética, 1451a 16

243 Aristóteles, Poética, 1451b 5

244 Aristóteles, Poética, 1451a 30-5

245 "é um todo aquilo que tem princípio, meio e fim. Princípio é o que necessariamente não vem depois de outra coisa, mas depois do que vem outra coisa por natureza ou geração. Fim, ao contrário, é o que por natureza vem depois de outra coisa, ou necessária ou freqüentemente, mas não é seguido de nenhuma outra. E meio, o que não somente se segue de outro mas também é seguido" Aristóteles, Poética, 1451b 26

246 TIE $\$ 38$

247 Espinosa: "vera methodus constat in (...) sôla puri intellectus cognitione, ejusque naturae, \&
} 
não pode ser tomado por um expediente preliminar, externo e independente do conteúdo pensado. É certo que, para a emenda do intelecto, é necessário que sejam resumidos todos os modos de perceber (adequados e inadequados) que o pensamento possui para afirmar ou negar, e é necessário que seja exposto seu funcionamento geral, pois, assim como o médico precisa estar de posse do conhecimento do que seja, para o corpo, fungi suo officio, assim também essa lógica precisa apresentar todas as possíveis funções de formação de idéias. Mas isso deve ir além da elaboração de um cânone das funções lógicas de afirmar ou negar, incluindo também - no exercício da norma do verdadeiro, realizado na idéia dada - o fundamento da ampliação de nosso conhecimento. Tanto é assim que Espinosa inclui, como segunda parte de seu método, justamente "fornecer regras para que coisas desconhecidas sejam percebidas segundo a norma [da idéia verdadeira dada]" "248, ou ainda "explicar a maneira com que há de ser empregado [esse modo de perceber] para que coisas desconhecidas sejam por nós inteligidas desse modo"249. E essa segunda parte do método tem em seu núcleo justamente o conhecimento das condições da definição perfeita.

Como o exame detalhado da definição genética procurará evidenciar ao longo deste ensaio, a lógica espinosana almeja ser não somente uma lógica da validade formal mas também - para empregar uma expressão que Kant reservaria exclusivamente para a lógica transcendental ${ }^{250}$ — uma "lógica da verdade". E o que talvez a lógica de Espinosa mais devidamente possua em comum com a noção kantiana de lógica geral aplicada é que ela não apenas consiste numa apresentação do uso geral do entendimento comum: ela o faz in concreto. Parece ser por isso que ela deveria realmente ser qualificada de aplicada, ou melhor, de efetivamente exercida (angewandte Logik), sem que isso, no entanto, significasse, para Espinosa, ir buscar algo "fora da lógica",251. O que talvez permita que Espinosa, diferentemente de Kant, possa considerar essa lógica como apta a nos conduzir pela ótima via, com passo seguro e sem desgaste, no conhecimento das coisas que mais importa conhecer ${ }^{252}$, ou seja, também como um Organon e não só como um kathartikon ou um Cannon, é o valor epistêmico do próprio exercício, do ato e da concretude que ele envolve:

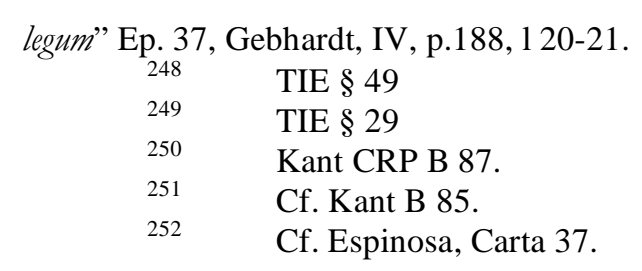


"O poder inato do intelecto não é uma possibilidade (possibility) mas uma capacidade ativa (active capacity) de formar "instrumentos intelectuais" pelos quais novos poderes são adquiridos para novas "obras intelectuais", e assim por diante",253

\section{4) LóGICA E ÉTICA NO PROÊMIO do DE EMENDATIONE.}

Recalcitrante, porém, talvez o objetor protestasse: essa caracterização do De Emendatione como uma lógica pode valer para a parte do tratado que vai do parágrafo 18 — no qual se inicia o exame dos modos da percepção — até o final do opúsculo, mas não corresponde ao conteúdo dos primeiros dezessete parágrafos, que são de cunho direta e eminentemente ético. Ora, além de responder dizendo que já se poderia simplesmente reconhecer algum sentido ético na noção mesma de Medicina Mentis, eu notaria que o proemio do tratado é marcado por uma explícita analogia médica, que se compõe com a analogia que a Ethica estabelece entre lógica e medicina:

"Via-me, pois, às voltas com um sumo perigo e coagido a buscar, com suma força, um remédio, ainda que incerto; assim como um doente enfrentando ${ }^{254}$ uma doença letal, que, quando prevê a morte certa se não administrar um remédio, é coagido a buscar este último, ainda que incerto, com suma força pois nele toda a sua esperança está situada,"255

Voltarei a comentar essa imagem médica - sobretudo no que diz respeito às relações entre remédio e certeza - mais ao final desta seção. O que eu gostaria agora de fazer é mostrar que a referida objeção — além de proporcionar que se evidencie, já no proêmio do tratado, a articulação entre ética e lógica sob certa idéia de medicina acaba por também ensejar, nesse ínterim, ainda mais evidências sobre a presença de um

De Djin, H. The Way to Wisdom. Purdue University Press, 1996; p.76

O particípio que traduzi por "enfrentando" é usualmente traduzido por "sofrendo" ou "que sofre". Justifico-me: no latim, trata-se de laborans, derivado de laboro, laborare, que significa laborar, trabalhar. No particípio, significa: que está em apuros, dificuldade ou perigo, que sofre, que é oprimido por, que é acometido de, que tem problemas com, etc. mas sempre derivadamente da idéia de trabalho: que trabalha sob, que tem trabalho com. Lembro-me aqui do proverbio bíblico, que conheço de oitiva: vita hominis octoginta anii, aplius eorum labor et dolor (a vida do homem é de oitenta anos, mais do que isso, é trabalho e dor). Minha tradução procura indicar que, sim, há sofrimento e, portanto, passividade, mas não de tal forma que o não haja enfrentamento, lida, esforço, trabalho, em suma, algum grau de atividade. Fiquei tentado a traduzir laborans por "que elabora", mas finalmente me pareceu - conquanto frutífero em ressonâncias psico-terapêuticas atuais — anacrônico em demasia.

255 TIE §7: "Videbam enim me in summo versari periculo, \& me cogi, remedium, quamvis incertum, summis viribus quarere; veluti ager lethali morbo laborans, qui ubi mortem certam pravidet, ni adbibeatur remedium, illud ipsum, quamvis incertum, summis viribus cogitur quarere, nempe in eo tota ejus spes est sita." 
diálogo com Aristóteles nessa obra de Espinosa ${ }^{256}$.

Com efeito, o percurso ético que constitui o assim chamado proêmio do $D e$ Emendatione é a narrativa de uma tomada de posição: tandem constitui ${ }^{257}$. Essa constitutio que coroaria certa experiência humana de valor exemplar — dependia da superação de um impasse, de uma aporia. Para caracterizar esta última e depois mostrar com algum detalhe como é que a lógica funcionaria como medicina da mente nessa solução, é apropriado começar pelos próprios termos do célebre parágrafo de abertura do tratado:

"Depois que a Experiência me ensinou que todas as coisas que na vida comum freqüentemente ocorrem são vãs e fúteis (vana et futilia); e como eu visse que tudo o que e por que eu temia, em si nada tinha de bom nem de mau, senão enquanto o ânimo fosse movido por isso, pusme finalmente (tandem constitui) a inquirir se dar-se-ia algo que fosse um bem verdadeiro e comunicável de si, e somente pelo qual, rejeitados todos os demais, o ânimo fosse afetado; mais ainda, se dar-se-ia algo que, descoberto e adquirido, eu fruísse eternamente com felicidade suprema e contínua" 258

A tomada de posição — sublinha o $\$ 2$ - não foi imediata. Até pelo menos o $\S 11$, o texto se dedica a contar, em um flash-back narrativo, as dificuldades enfrentadas

256 Faço aqui algumas reformulações sumárias de resultados interpretativos obtidos no Mestrado, que versou sobre o Proêmio do De Emendatione: "Investigação sobre o conceito de emendatio no proêmio do Tractatus de Intellectus Emendatione de Espinosa" (Dissertação, etc.). Mantive algumas notas filológicas que constavam da dissertação de mestrado porque considero que elas servem para preservar, neste resumo muito conciso, aspectos importantes da argumentação de Espinosa, que a camada lexical do texto, a seu modo, exprime de forma conveniente condensada.

257 As traduções frequientemente recorrem às noções de decisão ou resolução para traduzir "constitutio": tandem constitui = finalmente me decidi. Mas é importante lembrar que Espinosa considera que "os homens têm a opinião de que são livres por estarem cônscios de suas volições e apetites, mas nem em sonho cogitam as causas pelas quais são dispostos ("à quibus disponuntur") a apetecer e a querer, visto que as ignoram" (Ethica I, Apppendix; S.O. II, p.78,18). Portanto, as referidas traduções podem tornar-se problemáticas por sugerirem noções que, no seu uso corrente, indicam esse mesmo tipo de 'liberdade' ou 'independência de escolha' recusado pela filosofia espinosana. Se, em decorrência disso, um sentido distinto, não usual, deve ser assumido para as palavras "decisão" e "escolha", no vocábulo latino empregado, contudo, um tal sentido já está normalmente acessível. Constituo e constitutio, além do sentido de decisão, remetem primeiramente às noções derivadas de statuo através da composição com cum, tais como as de posicionamento conjunto, arranjo, organização, disposição, conformação, compostura, estabelecimento, fixação, definição, etc. Assim, ocorreu-me traduzir constitui por "pus-me a" ou "tomei posição", procurando indicar, com isso, que trata-se, antes, de inserir-se na conformação que se apresenta - não como seu joguete, mas, de pé, dela tomando parte - ao invés de um subtrair-se na abstrata independência do arbítrio. A acepção física, literal, de constituo, talvez permita pensar um sentido mecânico e imanente para o ato de tomar uma decisão, uma vez que indica a própria inserção adequada de um ato na série causal de que ele é um nexo.

258 TIE §1: "Postquam me Experientia docuit, omnia, qua in communi vitâ frequenter occurrunt, vana, \& futilia esse: cùm viderem omnia, à quibus, \& qua timebam, nibil neque boni, neque mali in se habere, nisi quatenus ab iis animus movebatur, constitui tandem inquirere, an aliquid daretur, quod verum bonum, \& sui communicabile esset, \& à quo solo, rejectis cateris omnibus, animus afficeretur; imò an aliquid daretur, quo invento, ¿ acquisito, continuâ, ac summâ in aternum fruerer latitiâ." 
até que a posição de inquiridor do verdadeiro bem se organizasse de maneira consistente, de modo que a constitutio narrada no primeiro parágrafo corresponde, na ordem dos acontecimentos, a um fato ocorrido depois do $§ 11$. A seqüência de processos parciais que leva a essa derradeira tomada de posição pode ser sumariamente descrita da seguinte maneira: primeiramente, o narrador diz haver aprendido com a experiência que, por um lado, os acontecimentos da vida comum são vana et futilia mas que, por outro, à primeira vista (primo intuitu), as comodidades nela adquiridas parecem coisa certa (rem certam), ao passo que as de uma nova vida parecem coisa incerta (rem incertam). Consequentemente, ele passa a revolver no ânimo ${ }^{259}$ possibilidades fortuitas de coadunar as duas institutiones vitce. Todavia, percebe que essas tentativas estavam fadadas ao fracasso, pois os bens da vida comum (divitias, honorem, e libidinem) arrastavam (distrabunt) a mente a ponto de incapacita-la para poder pensar sobre algum outro bem (de alio aliquo bono cogitare). Finalmente, depois de realmente ocupar-se (incubueram) da matéria $^{260}$, diz haver compreendido que toda sua felicidade depende da qualidade do objeto (qualitas objecti) a que se ligará por amor, qual seja, a qualidade de uma coisa eterna e infinita e que possa ser possuída (possideatur) por todos os homens sem temor (timor), inveja (invidia), brigas (lites) ou qualquer tristeza (nulla tristia) ${ }^{261}$. Entretanto, conclui o narrador, explicitando seu impasse: "embora com a mente eu percebesse tão claramente essas [coisas] nem por isso, entretanto, eu podia depor toda avareza, libido e glória"262.

Como superar tal dificuldade? Ora, antes de passar à resposta, convém notar, como forte indício da presença de um pano-de-fundo aristotélico nesse contexto, que os

\footnotetext{
$259 \quad$ \$ 3: "Volvebam igitur animo, an forte esset possibile ad novum institutum, aut saltem ad ipsius certitudinem pervenire, licet ordo, et commune vita mea institutum non mutaretur; quod sape frustra tentavi I Volvia, pois, no ânimo, [a perguntar] se acaso seria possível chegar ao novo instituto ou ao menos à certeza a seu respeito, ainda que não fosse mudado o instituto e a ordem comum de minha vida, o que muitas vezes tentei frustradamente". O verbo volvo, ere. indica, concretamente, volver, revolver, voltar em giro, girar, rolar, verter, despejar etc. Abstratamente e em sentido figurado, significa pensar e repensar, considerar a mesma coisa muitas vezes, conotando, pois, também nesse registro, um movimento circular, repetitivo. No contexto de seu uso por Espinosa, entendo o termo como conotando uma repetição sem condições internas, ou próprias, de dar fim a si mesma. Tal interpretação, ao menos no que se refere ao texto espinosano, é reforçada pelo advérbio forte, que comparece associado ao verbo no texto, ou seja, pela maneira fortuita com que uma conclusão apresentar-se-ia caso isso de fato viesse a ocorrer por meio desse expediente, ou seja, por meio do "volver em ânimo".

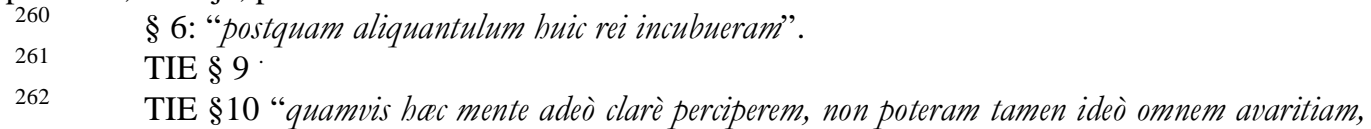
libidinem, atque gloriam deponere". Julgo apropriado salientar nesta frase o termo ideo, uma vez que ele tem a função de enfatizar que, se por ventura houver de fato alguma possibilidade de que se dê a referida deposição, não será simplesmente de uma percepção clara que essa possibilidade advirá de direito: "nem por isso eu podia depor, etc". Saliento também o advérbio quamvis
} 
três bens que compõem o conteúdo freqüente da vida comum e que são tidos pela maioria dos homens como summum bonum, são exatamente os mesmo trazidos por Aristóteles na Ética a Nicômaco. E deve-se notar, ademais, que o impasse final do processo acima descrito remete à problemática debatida por Aristóteles sobre o clássico tema ético da acrasia, como diz Aristóteles, ou "video meliora proboque, deteriora sequor", como diz um verso de Ovídio que Espinosa costuma citar a esse propósito ${ }^{263}$. Não estou afirmando, porém, que as posições de Espinosa sejam concordantes com as de Aristóteles a esse respeito, uma vez que o acrático stricto sensu deve "seguir o pior" estando, todavia, de posse de um conhecimento do "melhor" que seja cognitivamente irretocável. Só então é que Aristóteles consideraria haver acrasia propriamente dita. Este, contudo, não é, para Espinosa, o caso da mencionada "percepção mental clara" incapaz de vencer o amor pelos bens ordinários, pois julgo que ela corresponde, por exemplo, ao que a Korte Verbandeling diz da Fé Verdadeira (') ou Razão ('), a saber, que embora a ela caiba o conhecimento correto do bem e do mal, tal conhecimento se limita, no entanto, a captar o objeto conhecido mantendo-o numa irredutível exterioridade:

"Como tudo o que encontramos em nós mesmos tem mais poder sobre nós do que o que vem de fora, segue-se sem dificuldade que a razão (') pode ser causa da destruição das opiniões que adquirimos por simples testemunho (...) E será o mesmo se empregarmos aqui a palavra opinião ou paixão, com o que fica claro por que não podemos vencer, mediante a razão, aquelas [opiniões ou paixões] que estão em nós em virtude da experiência ('). Com efeito, essas opiniões não são em nós outra coisa senão uma fruição e uma união imediata com algo que julgamos bom, enquanto a razão, ainda que nos mostre algo que é melhor, não nos faz dele fruir. Assim, aquilo de que fruímos interiormente, não pode ser vencido por aquilo de que

\footnotetext{
"Vejo as coisas melhores e as aprovo, sigo as piores" (Ovídio, Metamorfoses, Livro VII, linha 20). É de notar a presença da temática da "sanidade" e do "arrastamento" também nos versos ovidianos contíguos a este citado. No referido Livro das Metamorfoses, dedicado a Jasão e Medéia, o verso citado é uma fala proferida por Medéia, ao ver-se em conflito por causa do amor indevido que subitamente passa a sentir por Jasão: "Si possem, sanior essem. Sed trabit invitam nova vis, aliudque cupido, mens aliud suadet. Video meliora proboque, deteriora sequor"/ Se pudesse, eu seria mais sã. Mas uma força nova arrasta-me invita; a mente persuade de uma coisa, o desejo, de outra. Vejo as melhores e as aprovo, sigo as piores". A situação é claramente uma oposição entre o que é exortado pela mens e pela cupido (substantivo feminino, cupido, inis, forma variante de cupiditas). $\mathrm{O}$ adjetivo sanus, a, um indica sanidade $\mathrm{e}$ saúde, mas, em oposição a valetudo, conota mais um estado psicológico de integridade mental, produzindo, no texto, um contraste com o estado de divisão vivido no mencionado conflito ("aliudque / aliud."). O dicionário de Lewis acentua a noção de inteireza e identidade no sentido de sanus, ao propor "sound" e "whole" ao invés de "healthy", e na mesma direção, é de notar a tradução de Brooks More (1922) para o trecho das Metamorfoses aqui em pauta: "if I could do so, I should be myself: but some deluding power is holding me helpless against my will. Desire persuades me one way, but my reason still persuades another way. I see a better course and I approve, but follow its defeat"
} 
não fruímos e que está fora de nós, como é o que nos mostra a razão. Assim, se essas opiniões devem ser superadas, deve existir algo que seja mais poderoso, como será uma fruição ou uma união imediata com algo que seja melhor conhecido e fruído do que o anterior - caso em que a vitória é sempre necessária - ou maior que o bem desfrutado" ${ }^{, 264}$.

Ao dizer que "será o mesmo se empregarmos aqui a palavra opinião ou paixão", Espinosa está tirando consequiências do que já dissera em $K V$ II, 2, 3, a saber, que "a causa próxima das paixões, na alma, é o conhecimento", afastando-se com isso da tradição que separa entendimento e vontade (mesn e cupido, no verso de Ovídio), em cuja história a doutrina aristotélica da acrasia - que separa razão e desejo — desempenha papel fundamental. Assim, se o conhecimento verdadeiro do bem e do mal, enquanto verdadeiro, não pode coagir nenhum afeto, mas apenas enquanto esse conhecimento é, ele próprio, um afeto mais forte ${ }^{265}$, é porque este último corresponde a "algo que seja melhor conhecido e fruído do que o anterior", ou seja, a um melhor conhecimento do bem e do mal. E não é outra coisa o que se encontra dito no $§ 11$ do De Emendatione:

"Via unicamente isso, que enquanto a mente versava acerca desses pensamentos, ao mesmo tempo daqueles [outros] se afastava, e seriamente pensava na nova instituição; o que foi para mim de grande consolo. Pois via que aqueles males não eram de tal condição (videbam illa mala non esse talis conditionis) que não cedessem a nenhum remédio. $\mathrm{E}$ embora, no início, esses intervalos fossem raros e durassem por muito pouco espaço de tempo, depois que o verdadeiro bem mais e mais me ficou sendo conhecido (postquam tamen verum bonum magis ac magis mihi innotuit), esses intervalos foram mais longos e freqüentes; sobretudo depois que vi que a aquisição de dinheiro, libido e glória só obstava quando querida por si mesma (propter se) e não enquanto (tamquam) meios para algo outro (media ad alia); se, na verdade, forem queridos como meios (tamquam media), possuirão moderação (modum habebunt) e

KV II, Cap. 22, parágrafo 2.

Refiro-me, aqui, a um conjunto de passagens passagens de Ethcia IV, em cujo Prefácio já se encontra parafraseado o dito ovidiano, aí presente quase como uma epígrafe de toda essa parte: . Veja-se, pois, os seguintes textos: prop. 1, em cuja demonstração destaca-se a fórmula "prasentia veri quatenus verum est / presença do verdadeiro enquanto é verdadeiro" então empregada para designar a dimensão do conhecimento verdadeiro que não é capaz de alterar as paixões; prop. 7; prop. 8; prop. 14 (praticamente transcrita no corpo do texto a que esta nota se refere); prop. 15, que mostra como o próprio desejo que provém do conhecimento do bem e do mal pode ser refreado ou extinto por muitos outros desejos provenientes dos afetos a cujo conflito estamos submetidos; prop 16, que, em conformidade com os textos supracitados de KV e com o contexto ora examinado em TIE, mostra como o caso descrito na proposição 15 se agrava quando o conhecimento do bem e do mal se refere ao futuro e concorre com afetos relativos ao presente; e finalmente prop. 17, que repete esse mesmo esquema, respectivamente, para o par contingência / presença, e em cujo escólio, depois de repetir o verso de Ovídio, Espinosa encerra tal descrição da impotência humana salientando a necessidade de conhecê-la. 
prejudicarão minimamente ou, ao contrário, muito conduzirão ao fim pelo qual (propter quem) são buscados"266

Como foi dito, Espinosa já havia reconhecido que a felicidade depende da qualidade do objeto (qualitas objecti) a que se liga o amor (§9). E já havia determinado que essa qualidade é a de algo infinito (§10). Mas esse conhecimento não bastava para vencer a força das paixões (final do §10). Ora, no §11, tal qualitas objecti é discernida de uma qualidade ingrediente no objeto e torna-se apenas aquilo que permite saber se uma coisa entrava ou amplia nosso poder quando disposta como (tamquam) fim ou como (tamquam) meio (isto é, porque bem ordenada será sempre um bem, ainda que seja finita e perecível). O emprego das noções de bem e mal depende, sim, de que seja consultada a qualidade do objeto amado (finito ou infinito), mas — vê-se agora — bondade e maldade não são, imediatamente, essa qualidade do amado e no amado. A origem suficiente da bondade ou maldade inclui, além da natureza do objeto (finito / infinito), sua condição de meio ou fim numa ação particular. Com efeito, a determinação da bondade ou maldade de algo se dá no jogo entre uma alternativa prática (meio / fim) e uma alternativa ontológica (finito / infinito):

Algo finito / como fim $=$ mal.

Algo finito / como meio $=$ bem.

Algo infinito / como meio $=$ mal.

Algo infinito / como fim $=$ bem.

É claro que essa solução não surgiu pronta no §11; ela foi preparada por todos aqueles processos parciais, nos quais pode-se verificar a construção desse resultado, conjuntamente com sua dependência de certas distinções lógicas. Veja-se, por exemplo, o que se passa com a noção de certeza, mencionada por Espinosa no contexto da aporia de querer abandonar um bem certo por um incerto (bonum certum pro incerto amîttere velle illa aversabatur, \& seriò de novo cogitabat instituto; quod magno mibi fuit solatio. Nam videbam illa mala non esse talis conditionis, ut remediis nollent cedere. Et quamvis in initio hac intervalla essent rara, \& per admodùm exiguum temporis spatium durarent, postquam tamen verum bonum magis ac magis mibi innotuit, intervalla ista frequentiora, \& longiora fuerunt; prasertim postquam vidi nummorum acquisitionem, aut libidinem, \& gloriam tamdiu obesse, quamdiu propter se, \& non, tanquam media ad alia, quaruntur; si verò tanquam media quaruntur, modum tunc habebunt, ¿ minimè oberunt, sed contrà ad finem, propter quem quaruntur, multùm conducent' 
§6). Com efeito, num primeiro momento ( $§ 2)$, a bondade da vida comum parecia certa porque dada, frente à nova vida, que parecia incerta porque não dada. Depois de um primeiro empenho efetivo em direção ao novo - o que é marcado pelos verbos tentare (§ 3) e incubare (§ 6) - a noção de certeza foi desdobrada e fez-se possível distinguir entre esta que é relativa à consecução, obtenção, disponibilidade ou presença de algo dito bom (certo sua consecutione), e uma outra certeza, relativa à fixidez, constância, invariabilidade ou caráter irrestrito da bondade desse algo (bonum fixum, certo sua natura). Diante desses novos parâmetros, tanto a vida comum quanto a nova vida são simultaneamente certas e incertas, mas não no mesmo sentido: a primeira é certa quanto à presença mas restritamente boa, ao passo que a segunda é incerta quanto à presença mas irrestritamente boa. Finalmente, por meio de uma assidua meditatio, foram tiradas, com a devida atenção e cuidado, as conseqüências dessa combinação de presença certa com bondade restrita, que são as características da vida comum. Tais conseqüências são o que aparece compactado na expressão que qualifica as ocorrências da vida comum como "males certos" (§7).

O momento crucial dessa meditação sobre a noção de certeza - meditação que consegue fazer o inicialmente desejável conteúdo da vida comum passar da condição de "bens certos" para a de "males certos" — é o ponto em que Espinosa mostra que o termo "certo" se diz em muitos sentidos: um correspondendo à presença atual ou disponibilidade (certo sua consecutione) e outro correspondendo àquilo que o filósofo liga à idéia de fixidez (bonum fixum, certo sua natura). Esse desdobramento da noção de certeza permite, primeiramente, quatro combinações gerais:

(1) Bem disponível (certo sua consecutione) e fixo (certo sua natura)

(2) Bem disponível (certo sua consecutione) e não fixo (incerto sua natura)

(3) Bem não atualmente disponível (incerto sua consecutione) e fixo (certo sua natura)

(4) Bem não atualmente disponível (incerto sua consecutione) e não fixo (incerto sua natura).

Ocorre, porém, que a expressão "incerto sua natura" significa justamente ausência de fixidez da natureza do bem, ou seja, significa que onde ocorre essa incerteza, o termo qualificado tanto pode ser 'bem' quanto pode ser o seu contrário, 'mal', pois a incerteza de que algo seja bom é a própria incerteza de que esse mesmo algo seja mau. A incerteza corresponde ao conhecimento parcial de algo que se afigura, nessas condições epistêmicas, como meramente possível. E tudo que se afigura possível é possível também para o contrário, pois o possível é o que não é contraditório com o 
ser e com o não-ser ${ }^{267}$. Ora, sem que se isso elimine o fato de que, para Espinosa, o possível e o contingente são categorias apenas epistêmicas e não ontológicas, penso ser útil aproximar da condição em que o narrador espinosano se encontra no presente contexto do tratado - um doente que, atacado por uma enfermidade fatal, antevê morte certa caso não encontre um remédio apropriado - , a seguinte passagem de Aristóteles:

“Tudo o que dizemos segundo o 'poder', é 'possível' também para o contrário; por exemplo, por exemplo, o que dizemos que pode estar são pode também estar enfermo (...) Assim, a potência para os contrários se dá simultaneamente; mas é impossível que se dêem simultaneamente os contrários, e também que se dêem simultaneamente os atos (por exemplo, estar são $e$ estar enfermo), de sorte que um dos dois será necessariamente o bem; ao passo que a potência será ambas as coisas ou nenhuma. Por conseguinte, é melhor o ato. Mas, nos males, o fim e o ato serão também necessariamente piores $^{268}$

No texto espinosano, a conversão dos bens incertos em males certos equivale à atualidade da doença e à impossibilidade de que se dêem simultaneamente os atos contrários (ninguém pode estar são e enfermo ao mesmo tempo e no mesmo sentido). Mas, como o modelo da doença admite a noção de remédio, e este remédio é incerto (pode ser obtido mas pode não ser obtido) recobra-se a possibilidade ao nível da cura, pois, é impossível ser são e enfermo, mas o enfermo em ato é remediado em potência, é curável, pois pode não ser curado e pode ser curado mediante a intervenção daquilo que decidirá essa possibilidade; e chame-se isso de remédio. Assim, como o que é possível será ambas as coisas (bem e mal) ou nenhuma, e como não fixo (incerto sua natura) significa, nesse contexto, o mesmo que possível (pode ser bom e pode ser mal), seguemse as seguintes sub-combinações a partir daquelas quatro primeiras:

A partir de (2), "Bem disponível (certo sua consecutione) e não fixo (incerto sua natura), gera-se (2.1), Mal disponível (certo sua consecutione) e não fixo (incerto sua natura);

e a partir de (4), Bem não atualmente disponível (incerto sua consecutione) e não fixo (incerto sua natura), gera-se (4.1) Mal não atualmente disponível (incerto sua consecutione) e não fixo (incerto sua natura).

Ora, das combinações iniciais, aquelas que comparecem explicitamente no

$267 \quad$ TIE $\S 53$

Aristóteles (1987), Metaphysica, IX, 9; 1051ª 5-17 - itálicos 
Tratado são apenas (2) e (3), correspondendo respectivamente aos bens ordinários ( $\$$ 6: "bonum certum (...) sua natura incertum") e ao bem almejado ( $\$$ 6: bonum incertum non quidem sua natura (...) sed tantum quoad ipsius consecutionem). Ora, em (3) não ocorre a expressão incertum sua natura. Logo, é através do desdobramento de (2) em (2.1) que se dá o surgimento do termo malum nesse texto em que, até então, só se falava do bonum: não se trata de qualquer acréscimo de elementos novos, mas apenas da aplicação de incertum sua natura sobre a noção de bonum. É de notar, pois, que mala certa, no $§ 7$ (mala certa pro bono certo omitterem), é exatamente a primeira parte da combinação (2.1) - males disponíveis ou presentes - enquanto a segunda parte de (2.1) - males incertos sua natura corresponde à possibilidade do remédio finalmente reconhecida no $\$ 11$ quando da superação da aporia de feição pseudo-acrática do §10: "via que aqueles males não eram de tal condição (videbam illa mala non esse talis conditionis) que não cedessem a nenhum remédio".

$\mathrm{O}$ verdadeiro bem mais e mais ficou sendo conhecido (magis ac magis innotuit) e foi revista a condição dos males (non esse talis conditionis). Não se tratava, pois, da superação de uma quadro de acrasia, porque o caso foi resolvido em termos cognitivos. E o conhecimento relevante foi da ordem das distinções: o mesmo é certo e não-certo, mas não no mesmo sentido; o mesmo é bom e não-bom, mas não no mesmo sentido. Esses "sentidos" são, como está claro, "sua natura /sua consecutione" (§6) e "propter se Itamquam media ad alia" (§11). Ora, parece-me evidente que estamos diante de transformações de um par mais fundamental, a saber, respectivamente, "in se / in alio", ou seja, diante da mesma divisão do ente proposta por Espinosa nos Cogitata Metaphysica no diálogo com a lógica escolástica (quando então recusa a divisão do ente em ente real e de razão). Aliás, em Cogitata Metaphysica I, 6, Espinosa atribui a origem da noção de um "bem metafísico" — independente de qualquer respectividade — justamente a esse peculiar preconceito que é uma indistinção entre distinções, ou seja, um 'engano de segunda ordem':

"Aqueles que procuram um bem metafísico, isento de toda respectividade, laboram em um falso preconceito, ou seja, porque confundem uma distinção de razão com uma distinção real ou modal" 269

269 "Qui autem bonum aliquod Metaphysicum quaeritant, quod omni careat respectu, falso aliquo praejudicio laborant; nempe quòd distinctionem rationis cum distinctione reali vel modali confundant'; Cogitata Metaphysica I, 6 [S.O. I 248,1] 
Ora, dizer que "bom é dito assim como o ente", ou seja, multiplamente, é, até aí, aristotelismo castiço, como poderá verificar todo aquele que ler o sexto capítulo do livro inicial da Ética a Nicômaco (1096 a 23ss), onde Aristóteles apresenta uma variação do uso de "bom" segundo sua conhecida a variação categorial: essência (e.g Deus e a Razão são bons), qualidade (e.g. a virtude ou excelência é boa), quantidade (e.g. a moderação é boa), relação (e.g. o útil é bom), tempo (e.g. a oportunidade é boa), lugar (e.g. o lugar conveniente é bom), etc. Nesses termos, o que Espinosa, crítico dos transcendentais, diz no mencionado trecho dos Cogitata Metaphysica é que bom e mau não se dizem na categoria da essência: "Considerada só a coisa, ela não pode ser dita nem boa nem má, mas apenas respectivamente a outra (...) e assim uma mesma coisa pode ser dita boa e má ao mesmo tempo sob diversos respeitos" 270 .

O que soluciona a aporia ética — como, de resto, célebres aporias ontológicas na história da metafísica - é a capacidade de dividir o ente sem contradição. Assim, o sumamente bom será justamente saber fazer uma discriminação de "sentido", saber usar o operador "tamquam", pois isto é a condição de possibilidade dos verdadeiros bens, e, portanto, algo suma e fixamente bom. Isso explica que, no $\S 13$, o termo summum bonum não se refira a uma coisa - que seria como um fim em si mesmo no interior da série dos acontecimentos da vida humana - mas sim como o próprio conhecimento da ordem natural (ou como uma natureza humana capaz de alcançá-lo), pois esse conhecimento nos liberta da concepção que vê o bem e o mal como qualidades inscritas no mundo e, assim, nos permite reordenar ou usar qualquer coisa que nos afete o ânimo, do modo mais propício à conservação do nosso ser. E, desse modo, sem que tenhamos de rejeitar nossas paixões — uma tarefa intrinsecamente fadada ao fracasso — poderemos fruir, sem interrupção, de suprema felicidade.

E essa interpretação me parece não somente lícita como, mais ainda, capaz de esclarecer alguns pontos obscuros do proêmio do De Emendatione. H. Joachim, por exemplo, considera a redação dos parágrafos 12 e 13 "a tal ponto compacta e abrupta que, tomada como está posta, é dificilmente inteligível. (...) A exposição é breve, dogmática e muito inadequada, além de, em um aspecto, verbalmente inconsistente com

\footnotetext{
"Res sola considerata neque bona dicitur, neque mala, sed tantùm respectivè ad aliam (...) ideòque unaquaeque res diverso respectu, eodemque tempore bona, \& mala potest dici”; Cogitata Metaphysica I, 6 [ S.O. I 247,25$]$.
} 
o que precede" ${ }^{271}$. Essa inconsistência residiria no fato de que, por um lado, do parágrafo 1 ao 11, "verum bonum” designava o objeto da inquirição, o que fazia esperar que Espinosa procedesse desenvolvendo sua concepção da "coisa eterna e infinita" que os parágrafos 9 e 10 nos exortam a amar; mas, por outro lado, sem que Espinosa houvesse advertido que o termo "verum bonum" seria provisório, passa, no parágrafo 13, a chamar ofim de summum bonum, e de verum bonum os meios que a ele conduzem; (meios, aliás, que passaram a incluir, no§ 11, os males que faziam a miséria da vida comum). E, de fato, dito assim, tudo isso parece muito inconsistente. Mas, como acaba de ser visto, depois que a percepção de que nada é bom ou mau em si mesmo ganha sua fundamentação última, a felicidade contínua - que sempre foi o que a posse do verum bonum havia de proporcionar — passa a ser possível a partir de qualquer coisa: o mundo, a Natureza, com todas as coisas singulares que a emendatio permite tomar como vera bona, é a coisa infinita e eterna à qual devemos nos ligar por amor. A Natureza: esta é a coisa, o objeto ou conteúdo da felicidade. O summum bonum é o conhecimento que reordena qualquer coisa - na Natureza - que nos afete o ânimo, do modo mais útil à conservação do nosso ser. Ou melhor, o summum bonum é ser ou fruir de uma natureza humana tal que realize esse conhecimento. O summum bonum é, por assim dizer, a forma da felicidade. E assim, completa-se a inversão total na qualificação dos acontecimentos da vida comum, em oposição à instituição da nova vida, ou seja, respectivamente: bens certos / bem incerto; bens incertos por sua natureza / bem incerto quanto à consecução; males certos / bem certo; bens verdadeiros (meios) / summum bonum (fim); bens verdadeiros (conteúdos) / summum bonum (forma).

O parágrafo 11 do TIE é, portanto, ao mesmo tempo socrático, na medida em que soluciona o problema do bem em termos cognitivos, e aristotélico, na medida em que esse conhecimento consiste em compreender que bem e mal devem ser pensados em vários sentidos.

${ }^{271}$ Joachim, H. (1958) pp 20-21. 


\section{CAPÍTULO II}

\section{Notas sobre a gênese histórica \\ da teoria espinosana \\ da definição genética}

O objetivo deste capítulo é traçar uma genealogia da teoria espinosana da definição genetica. A fim de fazê-lo, tomo como ponto de partida, o clássico comentário de Martial Gueroult. O comentador francês, no corpo de seu comentário sobre o método geométrico e a scientia intuitiva na Parte II da Ethica, ao examinar as origens da teoria espinosana da definição, atenua a importância do paradigma geométrico cartesiano. Por um lado, afirma que de fato pode ser encontrada nas Regulae e na Geométrie "a idéia de uma geometria genética que concebe os seres geométricos através do movimento que os engendra, desenvolvendo uma intuição fundamental sem interrupção" ${ }^{272}$, como se pode ver pela proposta de "conhecer todas as linhas, tanto as compostas quanto as mais simples, imaginando-as como descritas por um movimento contínuo ou por muitos que se encadeiam" 273 . Por outro lado, embora a idéia de uma intelecção das figuras geométricas através de sua gênese interna seja comum a Descartes e a Espinosa, Gueroult considera "duvidoso que se trate, de uma e de outra parte, da mesma gênese e da mesma geometria"274. As diferenças apontadas entre os paradigmas geométricos cartesiano e espinosano poderiam ser reconhecidas, segundo o comentador, no fato de que Descartes "estava atento, antes de tudo, à ordem e não à construção genética dos conceitos", o que poderia ser ilustrado por uma assumida preferência pela aritmética e não pela geometria ${ }^{275}$. As diferenças, assim, são referidas ao projeto cartesiano de substituir a geometria de Euclides por uma "disciplina inédita" — a geometria analítica - e ao correlato privilégio dado à análise em detrimento da síntese, que Descartes relega a um processo subalterno de exposição ou ensino, no qual são apresentadas demonstrações que na realidade foram obtidas alhures. Também em seu comentário sobre as definições da Parte I da Ethica ${ }^{276}$, Gueroult considera haver, entre o título das "Rationes ... probantes more geométrico dispositae" de Descartes e a "Ethica Ordine Geometrico Demonstrata" de Espinosa, o contraste que há entre a mera disposição exterior e o efetivo

${ }^{272}$ Geroult, M. (1968) p. 481

${ }^{273}$ Id Ibid

${ }^{274}$ Id Ibid

${ }^{275}$ Cf. Discours - A.T. VI, p 21, 113-18, apud Gueroult ibidem

${ }^{276}$ Gueroult, M. (1972) p. 35. 
compromisso de uma demonstração. Em filosofia, com efeito, a exposição sintética realizada por Descartes não possuiria, para ele próprio, “o valor de um ideal, mas tão somente de uma concessão"277.

Gueroult insiste, em contrapartida, na influência exercida sobre Espinosa pela reforma da geometria euclidiana empreendida pelos matemáticos de Oxford (sobretudo Savile), em cujo ambiente Hobbes desenvolveu sua própria teoria da definição genética, apresentada principalmente no De Corpore (1655) e na Examinatio et Emendatio Mathematicae Hodiernae. Emblemática dessa teoria é a mudança no aspecto descritivo da definição, que passa — sem propriamente se desligar — da consideração do que é gerado (descriptio generati) para a consideração de como se dá a geração (descriptio generationis). Tal como a entendo, no caso de Espinosa, a mudança do termo "gerado" para a o termo "geração" corresponde a uma mudança, por assim dizer, no registro categorial da descriptio, que passa de um o que é? para uma pergunta do tipo por que é o que é? prevendo uma resposta que diga como vem a ser. A definição, por exemplo, do sólido geométrico esfera não deve, então, descrever seu objeto apresentando-o como figura que possui tais ou quais características, mas sim como figura gerada pela rotação de um semicírculo em torno do eixo de seu diâmetro. Passa-se de uma concepção do descrever como atribuição de características — acidentais ou não — para uma concepção propriamente geométrica do mesmo termo, na qual sobressaem as noções de movimento regrado e de execução de um procedimento: mova um semicírculo de certa maneira e a figura assim descrita será uma esfera ${ }^{278}$. E será uma esfera particular, com dimensões particulares, a que resulta desse movimento aplicado a um semicírculo particular, ao passo que o universal, a 'esfericidade' comum a toda esfera, poderá — de bom agrado para pensadores de pendor nominalista — ser reduzida estritamente à regra do procedimento, ou seja, àquela maneira determinada de mover semicírculos, de maneja-los com o pensamento, de usa-los como ferramentas de pensar esferas. Assim, a 'quididade' - o “o que é” pensado em si mesmo - não precisa ser considerado como uma existência universal, ontologicamente independente da performance do ato mental,

${ }^{277}$ Idem ibidem, nota 64.

${ }^{278}$ Esta forma imperativa da definição, que vem acentuar o caráter procedural do descrever, pode ser corroborada por uma afirmação que Espinosa faz no inicio do TTP sobre os sinais do profeta. Lá ele diz que quem ouve o profeta não se torna profeta, mas quem escuta o filósofo torna-se filósofo. $\mathrm{O}$ enunciado imperativo (mova o semicírculo, etc.) indica que a definição é algo que você mesmo deve realizar. Pegar pronto não vale, porque a informação só é obtenível pela performance. Isso se liga com definição nominal. O caso, aqui, é mais complexo do que em Port-Royal, pois é porque Espinosa põe em primeiro plano o construtivismo geométrico (coisa que não está em primeiro plano em port-royal) que ele defende, como uma consequência, a diferença entre idéia e palavra (típica de Port Royal). 
isto é, da efetiva execução do procedimento ${ }^{279}$. Efetivamente pensar o semicírculo girando ao redor de seu eixo diametral é fazer com que exista em ato, como ser no pensamento, a mesma estrutura que, como ser no espaço, será uma esfera.

Como se vê, o que está em causa é bem mais que a mera introdução do movimento na definição de figuras geométricas. Caso assim não fosse, esse programa nada traria que já não houvesse sido escrito pelo próprio Euclides, que não é senão o autor da referida definição genética da esfera e de ainda outras, tais como a definição do cone através da rotação do triângulo ao redor do eixo de sua altura, e do cilindro através da rotação do retângulo. Todavia, houve quem, como Hobbes, manifestasse um significativo interesse pelo fato de que algumas das definições euclidianas - como a do círculo - não receberam do geômetra grego o mesmo tratamento cinético. Nas matemáticas dos dias de Hobbes, a novidade encontrava-se, pois, em não mais tomar como indiferentes essas duas modelagens definicionais euclidianas - cinética e estática — e em refletir sobre o que está implicado em cada uma no que diz respeito ao seu valor epistêmico. Não se trata, portanto, de uma recusa da geometria de Euclides e de uma conseqüente intenção de suplantá-la por alguma "disciplina inédita", trata-se, antes, de uma reforma, de uma correção, de uma emenda.

Passando por várias obras de Hobbes, Gueroult destaca "a estreita afinidade entre a geometria genética hobbesiana e o método de Espinosa", apresentando da seguinte maneira aqueles que enumera como os principais tópicos da emenda proposta pelo filósofo inglês:

“(1) as causas dos universais (universalia) [a esfera?] são conhecidas por si (notae per se); (2) elas se reduzem a uma: o movimento (nec motus aliam causam habere intelligi potest praeter alium motum); (3) da variedade dos movimentos nasce a variedade das figuras; (4) o movimento permite a definição per generationem; (5) por isso é possível a ciência [dessas figuras], pois que vere scire est per causam scire; (6) do movimento do ponto nasce a linha, do movimento da linha nasce a superfície, do movimento da superfície nasce o corpo; (7) assim, pelo movimento são obtidas todas as definições genéticas, como, por exemplo, a do círculo: 'figura descrita pela circundução da linha, existente no plano, da qual uma das terminações repousa'; (8) essas definições, ao contrário das definições estáticas, dão conta da

${ }^{279}$ Para a pergunta "o que é?", quando dirigida a uma esfera, a resposta deve vir sob a forma de uma instrução de manejo ou uso de semicírculos, assim como — num exemplo espinosano a ser aprofundado posteriormente — , para a pergunta "o que é?", quando dirigida a um martelo, a resposta deve vir sob a forma de uma instrução de manejo ou uso de qualquer elemento - uma pedra, um osso, a própria mão — apropriado ao martelar. 
possibilidade da coisa (...) e fazem conhecer todas as suas propriedades" 280

Boa parte desses tópicos está pressuposta na articulação interna do seguinte trecho da Examinatio et Emendatio Mathematicae de Hobbes, onde também se verifica uma semelhança patente com importantes textos espinosanos:

"A: - As definições não são os princípios das ciências?

B: - Com certeza.

A: - E não deve toda ciência derivar do conhecimento das causas?

B: - Seguramente.

A: - Portanto, o princípio da ciência é conhecimento da causa.

B: - Sim.

A: - Por consequência, a definição deve conter o conhecimento da causa.

B: - Concordo.

A: - É por isso que as melhores definições são aquelas que explicam a geração da coisa.

B: - Também concedo. Vejo que em Euclides as definições da esfera, do cone e do cilindro são feitas pela geração desses corpos, se bem que ele não definiu o círculo dessa maneira.

A: - Mas ele inseriu gratuitamente entre seus postulados, como coisa conhecida por si, que se pode descrever um círculo. Ora, como se poderia descrevê-lo senão pelo movimento?

B: - Entretanto, Euclides deveria ter dito que definir a esfera pela rotação de um semicírculo ao redor de seu eixo é representala tal como a podemos conceber e não tal como ela existe, pois a natureza jamais faz uma esfera dessa maneira.

A: - Aqueles que definem as figuras consideram as idéias que nelas são, não os corpos eles mesmos, e a partir daquilo cuja geração imaginam, eles deduzem as propriedades das coisas semelhantemente feitas, quaisquer que sejam sua origem [real] e a maneira [real] pela qual foram feitas" 281

Ora, é impossível não escutar os ecos desse texto de Hobbes soando, por exemplo, no $\$ 72$ do Tractatus De Intellectus Emendatione de Espinosa, onde se diz que

"Para formar o conceito de globo, finjo ad libitum uma causa, a saber, um semicírculo ser rodado ao redor do centro, e a partir da rotação como que se origina o globo. Esta é uma idéia plenamente verdadeira, e embora saibamos que globo algum jamais se originou assim na natureza, esta é uma percepção verdadeira e o modo mais fácil de

${ }^{280}$ Gueroult II p. 484 nota 68 - inciso meu. Foram omitidas nesta citação as copiosas referências que Gueroult faz às obras de Hobbes em cada um dos oito tópicos enumerados.

${ }^{281}$ Examinatio pp. 86-87 apud Geroult II, p 484 
formar o conceito de globo ${ }^{282}$

É certo que as semelhanças terminológicas e conceituais entre o De Intellectus Emendatione de Espinosa e a Emendatio Mathematicae hobbesiana não desfazem - como também ocorre entre outras partes dos sistemas desses filósofos — incontornáveis diferenças. Estas, como veremos oportunamente, passam, no presente contexto, pela ontologia e pela teoria do conhecimento e implicam distintas posições sobre as "as figuras (...) as idéias que nelas são e (...) os corpos eles mesmos", além de distintas concepções da causalidade, da generatio e de suas relações com o movimento. Todavia, julgo acertado e proveitoso colocar a noção espinosana de emendatio intellectus sob o mesmo tipo de preocupação geral que preside a emendatio mathematicae hobbesiana. $\mathrm{O}$ comparecimento, no tratado de Espinosa, não só da definição euclidiana da esfera mas sobretudo da definição genética proposta por Hobbes para o círculo, ou seja, para aquela figura a que Euclides não estendera o tratamento cinético, funciona como insígnia de filiação teórica a um programa de revisão da categoria da quididade ${ }^{283}$. E o proveito que isso traz consiste, primeiramente, em permitir que se entenda a emendatio espinosana não através de suas ligações — etimologicamente válidas - com ideário ascético do corretivo, da reconversão, do castigo, da purgação, mas sim através da idéia de um ajuste categorial que propicia o máximo reaproveitamento do que já está disponível. Com efeito, se for admitida uma raiz hobbesiana para o termo que comparece no título do tratado de Espinosa, torna-se natural considerar que o modelo cultural da emendatio é o reaproveitamento da geometria euclidiana através da radicalização de uma modalidade definicional que já existe nela própria, ou seja, de seus recursos construtivistas

${ }^{282}$ TIE § 72: "ad formandum conceptum globi fingo ad libitum causam, nempe semicirculum circa centrum rotari, \& ex rotatione globum quasi oriri. Hac sanè idea vera est, \& quamvis sciamus nullum in Naturâ globum sic unquam ortum fuisse, est hac tamen vera perceptio, \& facillimus modus formandi globi conceptum"

${ }^{283}$ A definição do círculo pela rotação da linha já havia sido proposta por Clavius em seu comentário aos Elementos: "começa assim a propagar-se com Clavius o problema de uma definição genética dos elementos matemáticos; embora seja ajustado admitir que Clavius não parece dar excessiva importância científica a esse fato, enquanto ele parece limitar-se a denunciar simplesmente a possibilidade dessa alternativa, revelando a não homogeneidade estrutural dos dois tipos de definição (nota: essa impressão pode ser sugerida pelo fato de que à dúplice definição do círculo, Clavius garante, paralelamente, uma dúplice definição da esfera; com efeito, à definição euclidiana da esfera como figura sólida formada pela rotação de um semicírculo, acrescenta a seguinte, calcada sobre aquela euclidiana do círculo: 'esfera é a figura sólida, compreendida por uma única superfície, para a qual, a partir de um ponto posto no interior da figura, as linhas retas tiradas são iguais entre si). É importante, porém, notar que a afirmação [de Clavius] da matemática como "a primeira" dentre as ciências corre em paralelo a um trabalho de reflexão crítica sobre seus procedimentos demonstrativos e, de modo particular, sobre a possibilidade de reformar, em sentido genético, a estrutura da definição" Biasutti, p 102. 
autóctones $^{284}$. A emenda espinosana do intelecto ficará então caracterizada, de modo perfeitamente análogo, como um trabalho de distinção e fomento da força nativa do intelecto para formar definições genéticas, reorganizando, a partir dela, a atividade definicional da mente e, portanto, tudo mais que se segue das definições.

É possível e legítimo propor uma conotação terapêutica para o termo emendatio em Espinosa e até mesmo falar de uma "cura do intelecto", mas, nesses termos, faz-se necessário decidir o que se pretende significar com o genitivo "do intelecto (intellectus)": um intelecto doente que é objeto de (genitivo objetivo) cura, ou um intelecto ativo que é o sujeito de (genitivo subjetivo) uma cura produzida em outro, este sim, doente? Embora os textos sugiram que a primeira alternativa é preferível, há bons escrúpulos conceituais para não conceber como doente ou falho de qualquer maneira (genitivo objetivo) o intelecto, que Espinosa concebe como uma força nativa para o verdadeiro. Nesse caso, tende-se a considerar que o doente em questão deve ser o homem, ou seu animus, que, sob o jugo da imaginação, será curado com ou pelo intelecto (genitivo subjetivo). Essa leitura se beneficia do $\$ 7$ do De Emendatione, onde Espinosa caracteriza uma das etapas da busca ética pelo Summum Bonum como a condição em que se encontra "um doente que sofre de uma enfermidade letal, prevendo a morte certa se não empregar determinado remédio, etc". Entretanto, um segundo proveito de conservar em mente uma influência da emendatio Mathematicae permitirá manter a fidelidade textual e considerar que o intelecto é de fato o objeto da emendatio, mas sem que isso suponha, em algum momento, qualquer falha em sua força natural para o verdadeiro (o que seria letal para o método, concebido como um pensar conforme a norma da idéia verdadeira dada). Sendo um procedimento que se exerce no interior das matemáticas, a emendatio hobbesiana se situa, aos olhos da epistemologia de Espinosa, como um ajuste dentro do verdadeiro. $\mathrm{O}$ falso não está em primeiro plano: a definição estática do círculo não é falsa, mas é a definição genética que fornece a norma para o modus optimus de dirigir o intelecto no verdadeiro conhecimento das coisas. Quando Espinosa escreve que a matemática trouxe ao homem uma outra norma da verdade, de que matemática se trata? Afinal, há procedimentos matemáticos que são verdadeiros e certos mas que não se prestam a exemplificar o conhecimento intelectual e exigem um expediente adicional chamado por

284 E talvez se possa ver nessa 'recuperação' do vigor genético da geometria euclidiana a idéia de uma 'cura' para a enfermidade algébrica de que tende a se aproximar o paradigma de inspiração analítica (na linha de Descartes e Port-Royal). Cf. .De Djin, sobre a disputa entre Hobbes e Descartes na filosofia holandesa da época de Espinosa. Nota do Gueroult sobre Leibniz fazendo "julgamentos severos" sobre a álgebra e a arithmética: (A Tschirnhaus, Ed. Gerh. Math. Schr., IV, p. 465; Idem, VII, p. 206. 
Espinosa de "cuidado",285, não sendo, nesta medida, um meio per se para a obtenção do que é necessário aos objetivos do tratado ${ }^{286}$. De que maneira as diferenças nas Mathematicae hodiernae interferem na compreensão da norma da verdade? Como aqui já se prenuncia e como também veremos mais tarde, o contexto das discussões sobre a definição genética traz uma perspectiva em que a tensão ressaltada não é entre intelecto e imaginação mas entre intelecto e razão. A emendatio concerne ao fortalecimento daquilo que o intelecto tem de diferente da razão, e não daquilo que eles tem de comum, ou seja, de sua aptidão para a verdade, que não precisa de cura. Finalmente, ainda assim permanece possível, mantendo o genitivo objetivo na leitura de Emendatio Intelectus, propor uma dimensão terapêutica para o termo emendatio e até mesmo falar de uma "cura do intelecto", mas sem traduzir diretamente emendatio por cura em contextos como o do título. A emendatio do intelecto (genitivo objetivo, que o intelecto recebe) possui uma dimensão terapêutica porque é, ao mesmo tempo, o princípio de cura do homem — que não se reduz ao intelecto - doente e, portanto, de uma cura do intelecto (genitivo subjetivo, que o intelecto empreende), mas não a cura de um intelecto doente. Pela noção de emendatio intellectus entendo, pois, um ajuste categorial - de conseqüências ético-terapêuticas $^{287}$ — na forma lógica da definição, produzido a partir da radicalização

285 O uso de termos relacionados a cauere remete ao mesmo procedimento comentado por Gleizer a propósito da critica de Espinosa à idéia quadro: há os que confundem idéia e imagem completamente - e nesse outro contexto Hobbes passa para candidato à crítica —, e há aqueles que não as diferenciam com suficiente cuidado (que Gleizer considera ser o caso de Descartes, que haveria mantido subrepticiamente o modelo pictórico como parâmetro para pensar a função representativa — ou referencial, como prefiro dizer - da idéia). Creio que, no De Emendatione, nas notas sobre os limites da razão, isto é, do terceiro modo de percepção, podemos encontrar esse mesmo risco, decorrente de uma falta de cuidado. Só que agora não entre imagem e idéia, mas entre idéia de propriedade e idéia da essência íntima da coisa. A forma não psicológica desse cuidado me parece poder ser pensada como uma discriminação categorial entre ser como possuir predicados necessários (definição ao nível da razão = trabalho eficaz com propriedades) e ser como ser o resultado de uma gênese que explica como e por que isso possui o que possui, visto que os mesmos predicados pertencentes à outra forma de definir agora protagonizam a gênese daquilo a que pertencem (definição ao nível do intelecto $=$ conhecimento da essência particular afirmativa, essência íntima da coisa). Isso me leva a afirmar (contra aqueles que opõem o TIE à Ethica pelo fato de o primeiro não conter a teoria das noções comuns) que, no entanto, se bem entendida a teoria da definição, o TIE já pressupõe uma necessária colaboração da Razão, que é uma escada (como diz KV). Mas então por que o TIE a 'condena' à inadequação? Como já disse em meu artigo (nos cadernos do CLE), é preciso supor certa equivocidade do termo inadequação (mas que não trai seu núcleo fundamental de sentido). No presente contexto, a inadequação da razão significa o tipo de limite, por exemplo, das definições estáticas, mas que são necessariamente verdadeiras! Isso se liga com o fato de que, nas definições reais, o definiendum não é tomado materialmente, como um puro som, mas significando algo. Isso precisa estar disponível para que, ademais, também haja uma reestruturação dinâmica desse disponível, transformado agora em um novo definiens.

${ }^{286}$ TIE $\S 19$

${ }^{287}$ A teoria espinosana da definição também pode ser pensada como uma fundamentação lógica para a abordagem das paixões, definidas na Parte III da Ethica. Mas não só a "psicopatologia" espinosana depende da teoria da definição, uma vez que parte da "terapêutica" é justamente compreender adequadamente as paixões que nos acometem. 
de uma distinção entre dois modelos definicionais já disponíveis no interior da geometria euclidiana. Esse ajuste não é uma passagem do falso ao verdadeiro mas uma variação categorial entre definições verdadeiras.

Destarte, se nos textos de Espinosa a forma básica da definição puder ser suficientemente expressa pela fórmula "per $S$ intelligo $P$ ”, então a variação categorial entre dois tipos de definições verdadeiras, a emendatio intellectus, deverá ser entendida como uma precisão no sentido do verbo intelligo, que é o responsável por designar a relação entre o $S$ a definir (o definiendum; por exemplo, esfera) e o $P$ que o define (o definiens, por exemplo, semicírculo). Nesses termos, a precisão trazida corresponderá à exigência de que intelligere $S$ seja pensa-lo como o efeito da aplicação de certo movimento sobre os elementos de $P$ (por exemplo, girar de certa maneira). Há, não obstante, ocorrências de fórmulas equivalentes a "per $S$ apello (dico, voco, etc.) P". Isso não significa que tais definições sejam puras convenções nominais. É verdade que algo da atividade de nomear pode ser até mesmo instrutivo para prefigurar uma função sintética da atividade intelectual de definir: chamar algo de $S$ é pretender ou sugerir que há alguma sorte de unidade sob o nome aplicado, como se vê pela necessidade de que, mesmo convencional, esse nome seja, desde então, usado sem equivocidade. Mas intelligere é, mais do que isso, afirmar a consistência lógica dessa unidade; afinal, é possível chamar uma contradição patente, tal como círculo-quadrado, pelo nome de “quimera”, mas não se pode imaginar e muito menos inteligir um círculo-quadrado ${ }^{288}$. Agora, mais distante ainda das meras definições nominais está a definição real emendada, ou seja, aquela em que o verbo intelligo recobra todo seu sentido construtivo $^{289}$, pois ela afirmará não apenas uma unidade consistente de elementos em $P$ mas também que - e aqui está o ajuste — se esses elementos forem submetidos a um movimento preciso (girar ao redor de seu eixo diametral), algo será produzido (esfera) e necessariamente possuirá certas propriedades e não outras.

O nome liga-se a um conceito por meio de convenções arbitrárias que, como tais, não se prestam a ser contestadas ${ }^{290}$, mas esse conceito, de sua parte, diferentemente de uma convenção arbitrária, precisa dar a conhecer algo sobre a coisa que também

${ }^{288}$ Cf. Cogitata Metaphysica

${ }^{289}$ Que, alias, já esta presente em lego, ere. Emendatio Intellectus como a recuperação da prima significatio do verbo intelligo, expressão lingüística do "reddendum intellectum aptum ad intelligere" de TIE $\S 18$.

290 Dentro em breve retomarei o tema da distinção entre definição real e definição nominal, quando comentar afinidades e oposições entre Espinosa e a Logique de Port-Royal acerca da definição. 
recebe seu nome: precisa, aliás, dar a conhecer nada menos que "o que" ela é, sua quididade. Por isso, a verdade e a falsidade não são alheias à definição real. E no caso da definição real genética, essa verdade se mantem mesmo quando reencontra algo que parece aproximar-se da convenção arbitrária (talvez no que ela contenha de autárquica), como na definição da esfera por meio de uma causa fingida ad libitum: "Esta é uma idéia plenamente verdadeira, e embora saibamos que globo algum jamais se originou assim na natureza, não obstante, esta é uma percepção verdadeira e o modo mais fácil de formar o conceito de globo".

Ora, começando por afastar-se da convenção nominal mas terminando por adentrar no território do verdadeiro e do falso, uma tal definição não se converteria em proposição e, nesta medida, não precisaria ser demonstrada? Como devem, afinal, se diferenciar a definição real e a proposição? Uma mesma coisa pode ser definida e demonstrada? É a propósito dessas questões que Gueroult desenha, ao lado de suas abundantes e persuasivas referências feitas no corpo do texto à matriz hobbesiana, mais discreto, nas notas de rodapé, um arco histórico em que, sem apoiar-se em momentos intermediários, reenvia a problemática seiscentista diretamente ao Organon de Aristóteles:

"Para Aristóteles (An. Post., II, c. 3, 90b) é absurdo pretender que aquilo que é conhecido por demonstração o seja por definição e vice-versa, pois isso é supor que o que não é cognoscível senão por demonstração pode ser conhecido também sem demonstração (...) Mas, de outra parte, Aristóteles, aprofundando a distinção entre a definição nominal e a definição real, admite que esta última envolve uma quasi-demonstração da essência (boion apodeixis tou ti esti)"291

Para explicar esta segunda possibilidade, Aristóteles emprega alguns exemplos que, como veremos ainda nesta pequena história da teoria espinosana da definição, povoam o território recoberto pelo arco traçado por Gueroult. É o próprio comentador que, na seqüência da citação ora feita, toma a iniciativa de explicar essa "quasidemonstração da essência" através do exemplo do trovão, apresentado em Analíticos Posteriores. Consultando o texto mesmo de Aristóteles, entendo esse tipo específico de definição real como sendo aquele que responde à pergunta "o que é o trovão? (ti esti bronté;)" com a seguinte formulação: "o barulho do fogo que se extingue nas nuvens

${ }^{291}$ Gueroult citando Aristóteles em Ethique I 
(psofos aposbennumenou puros en nefesin)", pois, segundo a meteorologia aristotélica, a resposta para a pergunta "por que troveja? (dia ti brontai;)" é justamente: "porque se extingue o fogo nas nuvens (dioti aposbennutai to pur en tois nefesi)". É o mesmo enunciado (logos) que responde às duas perguntas (o que é? ti esti; e por que é? dia ti), diferindo apenas pela posição, diz o filósofo. Além disso, diz que "barulho nas nuvens (psofos en nefesi)" também é "definição do trovão (oros brontes)" na medida em que é "conclusão da demonstração do 'o que é' (tês tou ti estin apodeixews sumperasma)". Ora, essa demonstração é explicitamente caracterizada como "silogismo do 'o que é' (sullogismos tou ti esti)". Portanto, se barulho nas nuvens é a conclusão de um silogismo, e se um silogismo concludente tem por termo médio aquele que comparece duas vezes nas premissas e nenhuma na conclusão, segue-se que o termo médio, no caso considerado, é o substantivo "fogo (pur)", associado justamente às forma do verbo, quais sejam, um particípio presente, "que se extingue (aposbennumenou puros)", e um verbo na terceira pessoa, "se extingue" (aposbennutai to pur)". A extinção do fogo é o termo médio e a causa da conjunção entre barulho e nuvem, que é o trovão. É esse termo médio que, inserido na resposta da pergunta "o que é trovão?", a torna, ao mesmo tempo, resposta para a pergunta "por que algo é um trovão?". E então: por que algo é trovão? Ora, um trovão é o que ele é, ou seja, barulho na nuvem (conclusão do silogismo: barulho = termo maior, nuvem = menor), por causa do fogo (termo médio); algo acontece com o fogo, ele se extingue e faz barulho (ligação do termo médio e do termo maior) e ele se extingue na nuvem (ligação do termo médio e do termo menor); é por isso (dioti) que trovão é barulho na nuvem, é isso que é ser para trovão. Definir trovão dessa forma, ou seja, pela demonstração silogística da quididade, é pensa-lo como o efeito da aplicação de certo acontecimento (no caso, extinguir-se) sobre o fogo; assim como inteligir a esfera pela sua causa é pensa-la como o efeito da aplicação de certo movimento (girar de certa maneira) sobre o semicírculo. Em que pese a dificuldade de compreender as opiniões de Aristóteles sobre os fenômenos meteorológicos, fica claro que, na definição demonstrativa do trovão, o fogo cumpre o papel do semicírculo e o extinguir-se, o papel de girar ao redor do eixo diametral, assim como fica claro que o protagonista, tanto na cena da definição quasi-demonstrativa aristotélica quanto na cena da definição genética moderna, é o termo médio causal.

A referência de Gueroult a Aristóteles sugere, portanto, que uma tradição particularmente interessada em explorar e aprofundar a "quasi-demonstração do o que 
$\hat{e} "$ - talvez no sentido da eliminação do afixo quasi (oion) — seria a linhagem na qual as teorias da definição, de Hobbes e de Espinosa, devem ser situadas. Mas, no caso de Espinosa, seria mesmo necessário buscar tão longe o modelo para um híbrido não monstruoso de definição e demonstração? A Logique de Port-Royal - que Espinosa possuía em sua biblioteca pessoal - é uma reputada fonte, na segunda metade dos Seiscentos, de ensinamentos sobre a definição nominal e a definição real. Ora, quanto ao ponto em questão, Arnauld e Nicole se pronunciam como segue:

"Falamos (...) das definições de nome e mostramos ser necessário não confundi-las com as definições de coisas; porque as definições de nome são arbitrárias <e incontestáveis>, ao passo que as definições de coisas não dependem de nós mas daquilo que está contido na verdadeira idéia de uma coisa (enfermé dans la veritable idée d'une chose), e não devem ser tomadas como princípios mas ser consideradas como proposições que frequentemente devem ser combatidas" 292

Ora, temos aí uma afirmação explícita de que as definições reais são proposições. Por que, então, insistir em falar de Aristóteles para comentar Espinosa? Há, por exemplo, comentadores que, como Dunin Borkowski ${ }^{293}$, propõem que Espinosa tenha elaborado toda sua teoria da definição a partir da Logique de Port-Royal, em particular do capítulo XII da primeira parte. Mas não é por acaso que busquei em Gueroult a pauta para esta breve história da teoria espinosana da definição. Embora não coincida noutros pontos com minha própria leitura da teoria espinosana da definição, a leitura de Gueroult deixa transparecer algo muito afinado com os interesses aqui vigentes quando, diante do estabelecimento dessa filiação simples e direta de Espinosa a Port-Royal, responde que:

"Esta é uma conclusão que parece excessiva, ainda que o livro figure na biblioteca pessoal do filósofo. A teoria de Espinosa é muito mais complexa: para ele, as definições geométricas comportam, ao mesmo tempo, uma definição de palavra e uma definição de coisa (aquela da essência). Ademais, a distinção entre definição de coisa e definição de palavra não é o que há de característico na Logique de PortRoyal, pois nós a podemos encontrar por toda parte desde Aristóteles, que parece ter sido o primeiro que a enunciou claramente em seus

\footnotetext{
${ }^{292}$ Logique, II, cap 16, p. 164

${ }^{293}$ Dunin Borkowski apud Gueroul I p. 25 nota 21 e apud Biasutti, p. 110
} 
Segundos Analíticos, II, Cap. 10, 93b, 28 ss"294

Não se trata do velho adágio de que toda filosofia não passa de um comentário de Platão e de Aristóteles, nem tampouco da sensata observação geral de que há uma grande variedade de influências simultâneas concorrendo para a produção da teoria espinosana da definição. O que me é útil na linha argumentativa de Gueroult é — além do que diz sobre Espinosa e Port-Royal serem diferentes - a referência sistemática a certo conjunto de textos dos Segundos Analíticos, toda vez que lhe parece necessário discernir a definição genética, de linhagem hobbesiana e espinosana, de outro tipo de definição real. Os Segundos Analíticos operam, assim, como o quadro de referência frente ao qual as várias teorias da definição, inclusive e sobretudo a de Espinosa, podem ser situadas.

Tome-se, por exemplo, o mencionado capítulo XII da Logique, no qual são comentados os "remédios para a confusão que nasce em nossos pensamentos da confusão entre as palavras", a "necessidade e utilidade de definir os nomes de que nos servimos", e a "diferença entre a definição de coisas e a definição de nomes". Em primeiro lugar, deve ser observado que — nesta que Dunin Borkowski considera ser a principal fonte da teoria Espinosa da definição - a distinção relevante para os autores é a que se faz entre definição real e definição nominal, ao passo que, na tradição assinalada por Gueroult, a emendatio, tanto mathematicae quanto intellectus, corresponde sobretudo a uma distinção entre definições reais. E quando, no Capítulo XVI da parte II, a Logique diferencia, agora sim, as formas da definição real, apresenta, porém, apenas as duas seguintes modalidades: "a mais exata, que conserva o nome de definição" e "a menos exata, que se chama descrição". A primeira é "a que explica a natureza da coisa pelos seus atributos essenciais, dentre os quais os que são comuns são chamados gêneros, e aqueles que são próprios são chamados diferença"; a segunda é "a que dá um conhecimento qualquer da coisa através dos acidentes que lhe são próprios e que a determinam o bastante para dela fornecer uma idéia que a discerne das outras". São exemplos de definições reais do primeiro tipo: o "animal $(g)$ racional $(d)$ " para homem, "substância $(g)$ pensante $(d)$ " para o pensamento, "substância $(g)$ extensa $(d)$ " para o corpo "ente $(g)$ perfeito $(d)$ " para Deus. São exemplo do segundo tipo as descrições das plantas e dos animais pela figura, grandeza, cor, e semelhantes acidentes, de tal forma que se pode considerar "dessa mesma natureza que as descrições dos poetas e dos

${ }^{294}$ Gueroult I Op. Cit p. 25 , nota 21 
oradores". Ora, nenhuma dessas definições reais, discernidas segundo o essencial e o acidental, possui a forma da definição quasi demonstrativa: "barulho (gen), gerado pela extinção do fogo (termo médio com verbo), na nuvem (dif esp)". Do ponto de vista da forma, esta última contem todos os elementos do silogismo encerrados nela mesma e, por isso, é como que uma demonstração (oıov $\alpha \pi \circ \delta \varepsilon \xi \iota \sigma)$. A definição real genética toma por modelo a estrutura não tanto de uma proposição mas sim de um silogismo compactado, de uma conclusão que conserva uma referência ao processo de sua obtenção ou, como diz Espinosa, de uma proposição que conta com todas as suas premissas e, portanto, é logicamente adequada, suficiente para provar o que propõe. A definição real mais exata comentada pela Logique corresponde apenas ao resultado do silogismo definicional: "barulho (gênero) na nuvem (diferença específica)".

Estas são as diferenças que encontro entre a definição genética e a definição real de Port-Royal. Deve-se notar, entre outros pontos, que a forma da definição real mais exata, apresentada logo acima pelas palavras de Arnauld e Nicole, corresponde a apenas uma das definições contempladas por Aristóteles: "barulho (gênero) na nuvem (diferença específica) ${ }^{, 295}$. Ao menos nos capítulos que consultei, nada encontrei na Logique que associasse à definição real uma forma como "barulho (gen), gerado pela extinção do fogo (termo médio com verbo), na nuvem (dif esp)". Do ponto de vista da forma, esta última contem todos os elementos do silogismo encerrados nela mesma e, por isso, é como que uma demonstração (boion apodexis). A definição real genética toma por modelo a estrutura não tanto de uma proposição mas sim de um silogismo compactado, de uma conclusão que conserva uma referência ao processo de sua obtenção ou, como diz Espinosa, de uma proposição que conta com todas as suas premissas e, portanto, é logicamente adequada, suficiente para provar o que propõe (o equivalente lógico de uma causa adequada). A definição genética seria, pois, como que uma auto-demonstração, uma auto-implicação-performativa, algo como o inverso de uma redução ao absurdo ou de uma contradição-performativa que, em Espinosa, tem o sintomático enunciado de "pensa se puderes". Diante da definição genética da esfera, o enunciado mudaria para: "pensa o semicírculo girando em seu eixo diametral e não pensa, se puderes, uma esfera". Essa "redução à evidência" ajuda a compreender a afirmação espinosana de que "a essência objetiva é a própria certeza" (isso também é

${ }^{295}$ Trovão é do gênero dos barulhos (pois alguém que ouve um barulho [o exemplo de Espinosa na KV, sobre o cachorro latindo é perfeito para isso] pode perguntar se é um trovão), e sua diferença específica é dar-se nas nuvens. 
relevante para compreender como a teoria da definição se relaciona com a recusa espinosana de uma "dúvida metafísica" de estilo cartesiano).

A partir desta análise das diferenças com Port-Royal, confirmam-se algumas opiniões bastante sintéticas de Franco Biasutti — in "La Dottrina Della Scienza in Spinoza", sobretudo Capítulo 3 - sobre o lugar de Port-Royal na história da definição genética, todas mostrando aspectos distintos da idéia de que "il contributo della Logique ad una effetiva ristrtturazione della logica pare abbastanza limitato, per lo meno in rapporto ai tentativi operati in quello stesso giro di anni da Hobbes e da Spinoza". Segundo o comentador, o projeto de uma lógica baseada sobre a definição genética interrompe a continuidade, isolando um bem preciso contexto de pensadores, dos quais Espinosa constitui, talvez, o ponto mais alto, enquanto tal projeto em seu sistema é orientado à meta mais ambiciosa.

A despeito dessas diferenças, também podem ser reconhecidas algumas as semelhanças que julgo possível encontrar com Port-Royal, das quais desejo salientar duas:

(i) afinidades não quanto à definição real mas quanto à definição nominal. Neste ponto, seria natural apelar para a carta IX, de Espinosa a Luis Meyer, pois nela Espinosa também dá exemplos de definições nominas análogos aos que Arnauld e Nicole dão (e.g. chamar de paralelogramo uma figura de 3 lados). Todavia, na Carta Espinosa discute Clavius e Borelli e não a Logique.

(ii) a presença na Logique de um discreto parágrafo que diz que "Também há definições ou descrições que se fazem pelas causas: pela matéria, pela forma, pelo fim, etc., como se definíssemos um relógio, uma máquina de ferro composta de diversas engrenagens, cujos movimentos regrados são próprios para marcar as horas". Esta citação é útil para indicar a relevância do exemplo ligado à idéia de instrumento. Mas, nada no texto da Logique indica que esse modelo do instrumento fabricado detenha o interesse central dos autores. E também se pode observar, como um detalhe que me parece sintomático, que os autores tenham substituído por um "Etc." a causa eficiente, na enumeração que fizeram. Certamente não seria essa a que Espinosa deixaria de fora, nem que fosse apenas por uma razão estilística. Esse "detalhe" aponta para a questão, premente nos Seiscentos, acerca do papel da causalidade eficiente como princípio de determinação — sob a forma de movimento — da essência dos entes geométricos. Esse tema é trabalhado por Marilena Chaui, tanto no artigo sobre "Causa eficiente na 
matemática: a posição de Espinosa"296 ${ }^{29}$ quanto no Nervura do Real, sempre em relação com o conceito da demonstração potissima (demonstração causal perfeita) e com o contexto da quaestio de certitudine. Esse tema será mais detalhado futuramente nesta mesma história — interessada — da definição genética.

Acertadas as contas com Port-Royal, fica respondido por que, para estudar a teoria espinosana da definição (e demais noções que lhe são correlatas), é não apenas pertinente e relevante mas necessário remeter-se a Aristóteles. Caberá ao estudioso da Logique a tarefa da investigação exaustiva dessa obra para decidir o justo grau de afinidade entre a teoria espinosana da definição genética e a teoria da definição real de Arnauld e Nicole. Este, porém, não faz parte dos interesses da presente pesquisa, que se pautam muito mais pelo arco diretamente traçado por Gueroult entre Espinosa e Aristóteles. E se o comentário estruturalista não apresentou, sob o arco a que alça o conceito, as mediações históricas que conectam a teoria espinosana da definição à antiguidade clássica, houve, porém, quem procurasse empreender esse paciente trabalho terrestre.

${ }^{296}$ Kriterion No. 97, Janeiro a Junho de 1998 


\title{
CAPÍTULO III
}

\author{
A teoria espinosana da definição, \\ a crítica à concepção cartesiana da extensão \\ e o problema do Um e do Múltiplo \\ na correspondência final com Tschirnhaus
}

\section{1) Preliminares}

Neste CAPÍTULO, Pretendo comentar as últimas cartas da correspondência entre Espinosa e Tschirnhaus (Cartas 59 e 60 e 80 a 83), a partir da correlação que nelas se verifica entre a teoria espinosana da definição pela causa eficiente e a crítica à concepção cartesiana da extensão como massa inerte (“molem quiescentem”). Essa correlação será apresentada como a dupla expressão de uma mesma problemática ontológica - o clássico problema do uno e do múltiplo - que se desdobra simultaneamente em uma via lógica e em uma via física, integradas no sistema de Espinosa pela tese da isonomia entre as modelagens do vínculo lógico e do vínculo causal, de acordo com sua conhecida formulação "causa seu ratio" e com sua proposição da identidade entre a ordem e conexão das idéias e a ordem e conexão das coisas.

Será sugerido que a solução espinosana para o problema do uno e do múltiplo reformulado a partir da tese da unicidade substancial — depende da teoria dos modos de percepção, entendida não como uma teoria apenas epistemológica mas principalmente como uma teoria lógica dos modos da cópula (i.e. das diversas forma de "cohaerentia" entre os componentes das idéias), correspondente, ademais, a uma teoria dos modos de composição dos entes físicos reais. A definição perfeita fica, assim, caracterizada principalmente pelo tipo de articulação ou envolvimento causal adequado, mantido por seus componentes. $\mathrm{O}$ nexo adequado entre esses componentes seria o mesmo que preside a composição dos modos extensos a partir do atributo Extensão, havendo, não obstante, outros modos de composição correspondentes a outros sentidos da copula, isto é, a outros modos de afirmar e negar.

Nessa medida, ganha plausibilidade a tese de que a teoria dos modos de percepção (ou gêneros de conhecimento) desempenha, no interior do sistema espinosano, um papel análogo ao que a teoria das categorias desempenha no sistema aristotélico, no contexto da superação da lógica eleata, muito embora haja significativas diferenças entre a concepção de ambos os filósofos quanto à categoria da quididade, ou 
seja, quanto à forma da resposta para a pergunta “o que é?”.

Como se vê a partir deste resumo, alguns pontos já foram, na ordem da tese, previamente comentados, ao passo que outros receberão esclarecimento ao longo da exposição que se segue. A correlação com o problema do uno e do múltiplo, beneficiando-se do que já foi trazido no CAPÍTUlo I, aboradrá a correspondência com Tschirnhaus através da seguinte estratégia:

(i) Partirei dos artigos de Matheron "Physique et ontologie chez Spinoza: l'enigmatique réponse à Tschirnhaus" e "Essence, Existence and Power in Ethics I: the foudations of proposition 16)". Aqui, coerentemente com o que vem sendo dito acerca da inserção da teoria espinosana da definição no contexto da revolução científica dos séculos XVI e XVII, destacarei a estratégia de Matheron de começar seu comentário sobre a correspondência com Tschirnhaus falando da "questão da fundamentação ontológica da física galileana". Duas posições são delineadas pelo comentador: a) ou bem a nova física é ontologicamente verdadeira (e, portanto, seus enunciados fundamentais devem poder ser deduzidos de princípio ontológicos), b) ou bem esses enunciados não podem ser deduzidos de uma ontologia e a nova física não é ontologicamente verdadeira. Neste último caso, pergunto eu, o que ela seria? Ora, a resposta é conhecida desde as querelas de Galileu com a inquisição (Bellarmino) acerca da interpretação realista da hipótese copernicana da rotação diária da Terra: a física seria um instrumento de cálculo. A posição de Espinosa certamente seria a primeira, mas com importantes qualificações; sobretudo se lembrar-mos da problemática do fingo ad libitum, que exigirá um exame de conceitos tais como os de ficção e de hipótese.

(ii) Como isso se relaciona com o problema do Um e do múltiplo? Para responder a isso, recorro ao já citado artigo de Francis Wolff: "Dois destinos possíveis da ontologia: a via categorial e a via física”, publicado em 1996 na revista Analytica. Nesse artigo, Wolff, perguntando-se justamente "quais são as vias que se oferecem ao pensamento após Parmênides" na antiguidade clássica, falará de um "paralelismo",297 entre as duas vias que se abrem: a via física e a via categorial. Nessas duas vias, trata-se de "partir das exigências de Parmênides e concilia-las com uma exigência fenomenal".

De um lado, no Sofista de Platão (em especial através da doutrina dos 5 gêneros: movimento, repouso, ser, mesmo e outro) e no Organon de Aristóteles (em especial nas

${ }^{297}$ A expressão é de Wolff. Op. Cit. p. 203. 
Categorias, mas não só), o que se exige contra Parmênides é a possibilidade do discurso sobre o que é. É isso que se quer proteger do eleatismo. Pois se, como quer Parmênides, há apenas um modo de ser, então uma coisa

“é ela mesma, é seu ser e ponto final. Ela é o que ela é, um homem é um homem (...) Cada coisa teria por ser tão somente seu nome apropriado (...) Para [não apenas designar algo mas] dizer algo, é preciso, porém, evidentemente supor que, além se seu ser (pelo qual ela é o que ela é, e é dele que se fala), ela é outra coisa (pelo que ela é tudo que se pode dizer dela, branca, grande, etc). A estrutura atributiva da linguagem fica comprometida se "ser" tem somente um sentido"298.

Mas, ainda explica Wolff, nem mesmo designar algo, dizer que algo é homem, permaneceria possível, pois, se "ser" tem um único sentido, a linguagem só poderia ser feita de nomes próprios: de Sócrates só se poderá dizer que é Sócrates e já não mais homem... e no limite, tampouco se poderia, pela mesma razão, chamar de Sócrates este Sócrates de pé hoje, diferente que é daquele Sócrates sentado ontem. Se "ser" é apenas a estrita identidade, não há logos, e os eleatas, assim como Crátilo, discípulo de Heráclito, só encontrariam a coerência quando em silêncio, um silêncio que calaria talvez o núcleo mesmo do pensamento. Em moldes eleatas, não é possível pensar de uma coisa algo que ela verdadeiramente seja, sem que isso signifique uma estrita tautologia. E se nada há fora da totalidade, e se da totalidade só se podem afirmar tautologias, ela será a única coisa a ser (uma vez que, por exemplo, ser qualquer uma das partes já pressuporia que "ser" tivesse um segundo sentido). Neste caso como no de Sócrates, "ser", ou melhor, para sermos estritos, "ente", se tornaria apenas o nome próprio da realidade, e absolutamente nada informaria sobre ela. Finalmente, "tudo é um e não se pode dizer mais nada". Assim, Platão e Aristóteles, a despeito de suas diferenças, podem ser agrupados por Wolff como afirmadores de uma necessária multiplicidade de formas de ser (na qual se funda a linguagem, que exprime essa multiplicidade com as múltiplas formas de dizer o ser). É introduzido o não-ser, mas esse não ser-não não é o não-ser absoluto e sim o Outro (noção central para Espinosa, cuja divisão do ser não é justamente entre ser absoluto e nada (CM I,1 o ente não se divide em ente e não-ente", etc), mas entre ser em si e ser em outro)

Por outro lado, os atomistas (apresentados por Aristóteles no De Generitone), trilhando a via física, se vêem obrigados a salvar o movimento e a multiplicidade (os

${ }^{298}$ Cf. Wolff p. 182-183 
constituintes do objeto formal da física) através da admissão do vazio, que passa a fazer neste contexto as vezes que o não-ser vinha fazendo na via lógica (e não é outra coisa o que Tschirnhaus quer saber de Espinosa: qual a verdadeira definição do movimento e qual a origem da multiplicidade modal, dotada de figuras, etc). Os atomistas, resume Wolff, argumentavam da seguinte maneira: "sem vazio, nada de movimento; mas há movimento; Logo, há o vazio". Aristóteles, também no De Generatione, diz então algo que nos reconecta com o artigo de Matheron: "Leucipo pensava dispor de argumentos (logoi) que, estando de acordo com os dados sensíveis, não aboliam nem a geração nem a corrupção". Esse texto contrasta diametralmente com a atitude dos eleatas, descrita por Aristóteles (ibid): "Partindo de seus argumentos (logoi), passando em silêncio o testemunho dos sentidos e negligenciando-o sob o pretexto de que é preciso seguir somente a razão, alguns pensadores ensinam que o universo é um, imóvel e ilimitado, etc.”. Ora, de minha parte, reconheço haver uma identidade entre a postura epistemológica mantida por Aristóteles contra os eleatas e a que ele mantém, justamente no contexto de discussão sobre a real configuração do sistema solar, contra os pitagóricos: ao forjar uma jamais vista anti-Terra para totalizar o número de planetas previsto pela teoria ( $\log 0 \imath$ ), os pitagóricos não procuram "salvar os fenômenos", expressão que, como se sabe, se degenerará, sob as mãos da inquisição, na máxima instrumentalista de que é a isso que a ciência deve se limitar.

(iii) O que é a nova física? O logos intransigente, que se afirma em detrimento dos fenômenos? Ou um logos servil, reduzido a um instrumento de descrição dos fenômenos, tomados, estes sim, como parâmetro do real? A partir do também citado artigo de Luis Henrique Lopes dos Santos, sobre “A Harmonia Essencial”, é possivel mostrar como a questão do uno e do múltiplo articula, em seu interior, a problemática epistemológica do instrumentalismo, sob a égide da questão geral, lógico-ontológica acerca da relação entre a estrutura elementar do pensamento e a estrutura elementar da realidade.

(iv) Com o já mencionado livro de Lucas Angioni, justamente sobre "Ontologia e Predicação em Aristóteles", procuro mostrar qual é a estrutura elementar da realidade suposta, segundo o Estagirita, pela estrutura predicativa do pensamento, dando particular atenção à distinção entre a forma substância-acidente, a forma substânciapróprio e a forma substância-essência. Trata-se da divisão de sentidos do ser apresentada por Aristóteles nos Tópicos, obra que me parece estar muito presente na 
trama intertextual subjacente à teoria espinosana da definição. Esse quadro conceitual será útil não só para o que vem agora em seguida mas também para a tese até o seu desfecho (pois considero que a teoria espinosana da definição deve ser entendida como uma profunda mutação nesse quadro, mas nesse quadro, tal como anteriormente já procurei defender). Assim, passo ao comentário sobre a correspondência com Tschirnhaus.

\section{2) As questões de Tschirnhaus}

Na Carta 59, para Espinosa, Tschirnhaus solicita a este último duas definições. Por um lado, solicita "a verdadeira definição do movimento" e "a razão pela qual possamos deduzir a priori - sendo a extensão, enquanto concebida per se, indivisível, imutável, etc. - que podem se originar tantas e tão numerosas variedades" de corpos com figuras e movimentos. Por outro lado, Tschirnhaus também solicita a "verdadeira definição da idéia adequada, verdadeira, fictícia, falsa e dúbia" e concentra-se na indagação pela diferença entre a idéia verdadeira e a idéia adequada.

A solicitação das condições de detubilidade a priori de uma variedade a partir da extensão imutável e indivisível é explicitamente relacionada por Tschirnhaus aos "lemas acrescentados à segunda parte da Ética", o que esclarece que o que está sendo solicitado é a demonstração dos princípios de composição, diferenciação, individuação, e conservação - constitutivos da multiplicidade interna ao mundo físico - a partir de uma concepção da extensão na qual essas coisas não estão dadas.

A solicitação da definição da idéia adequada, por sua vez, relaciona-se à doutrina do método exposta no De Emdnatione, pois, além da referência à problemática das "idéias verdadeiras, fictícias, falsas e dúbias" — amplamente abordada nesse tratado na primeira parte do método - Tschirnhaus se refere ao "método de dirigir retamente a razão para adquirir o conhecimento de verdades desconhecidas", que é literalmente a tarefa que o tratado espinosano atribui à segunda parte de sua investigação metodológica: "fornecer regras para que coisas desconhecidas sejam percebidas segundo a norma [da idéia verdadeira]" [\$49], ou ainda "explicar a maneira com que há de ser empregado [o quarto modo de percepção] para que coisas desconhecidas sejam por nós inteligidas desse modo" [\$29]. E essa segunda parte do método tem em seu núcleo justamente o conhecimento das condições da definição perfeita.

Assim, as solicitações de Tschirnhaus mobilizam temas contidos, 
respectivamente, na pequena física da Ethica e na teoria da definição do De Emendatione. Mas não se trata de uma mera justaposição temática e sim, como afirmei de início, de uma correlação, pois, assim como no pedido de dedução da multiplicidade física apenas a partir da Extensão, também no caso da definição da idéia adequada trata-se de definir algo que deve funcionar, por si mesmo, como fonte de uma multiplicidade. É nesse sentido que deve ser lida a consideração de Tschirnhaus - correta mas incompleta de que a idéia adequada se caracteriza justamente por sua potência para uma dedução total: "a partir de qualquer idéia adequada é possível deduzir tudo aquilo que da coisa pode ser sabido"; e "embora [uma idéia] seja a idéia verdadeira desta coisa, ainda não poderá determinar tudo que é necessário ser conhecido acerca dela, a não ser que [se] venha a ter alguma idéia adequada dessa coisa".

Ambas as solicitações - em física e em lógica - exprimem, portanto, uma mesma dificuldade, como o próprio Tschirnhaus evidencia na carta 82 ao explicitar o que está por trás de seu interesse nesses dois problemas de dedutibilidade: "sempre observei que nas matemáticas, a partir de uma coisa qualquer em si mesma considerada, isto é, a partir da definição de alguma coisa, somos capazes de deduzir uma única propriedade, e que, se desejarmos mais propriedades, é necessário referir a coisa definida a outra, já que, então, da conjunção das definições dessas coisas resultam novas propriedades". A esse propósito, Tschirnhaus se vale do exemplo do círculo - recorrente nos textos espinosanos sobre a teoria da definição — dizendo que, da periferia do círculo em si mesma considerada, não se pode concluir outra coisa senão o que aí já estava compreendido, e finalmente reconhece que isso lhe parece "de algum modo oposto à proposição 16, que é talvez a mais importante do livro 1 [da Ethica], na qual assume-se como sabido que da definição de alguma coisa é possível deduzir múltiplas propriedades, o que me parece impossível se não a referimos a outra coisa". E Tschirnhaus conclui da seguinte maneira (explicitando cabalmente o vinculo subjacente entre suas duas ordens de questões): "é isso que fez com que eu não pudesse ver por que razão, de um atributo considerado sozinho, por exemplo, da Extensão, pudesse surgir uma infinita variedade de corpos".

As duas ordens de questões são, pois, configurações do clássico problema do uno e do múltiplo, desdobrado em duas vias igualmente clássicas: a via lógica e a via física (pra parafrasear Francis Wolff em seu artigo "Dois destinos possíveis da ontologia: a via categorial e a via física", publicado em 1996 na revista Analytica, e que subjaz a boa parte de minha exposição hoje). Afinal, e em última instância, o que 
Tschirnhaus solicita são as condições lógicas e físicas da multiplicidade modal afirmada pela proposição 16 da Parte I da Ethica, ou seja, as garantias de Espinosa contra a imputação de eleatismo que, de Bayle a Hegel, passando por Leibniz e Kant, é feita contra seu sistema, contaminando inclusive boa parte da primeira recepção do espinosismo na filosofia contemporânea até meados do século XX.

Com efeito, como conhecer verdades desconhecidas se não é possível deduzir necessariamente de uma coisa nada senão a propriedade essencial que já estava compreendida em sua definição? É certo que, como bem entendera Tschirnhaus, " $a$ partir de qualquer idéia adequada deve ser possível deduzir tudo aquilo que da coisa pode ser sabido" mas, afinal, o que pode ser sabido da coisa quando esta é tomada em si mesma, isto é, apenas em sua definição, ou seja, a priori? Por exemplo, do círculo, definido apenas pela propriedade de ter todos os pontos da periferia equiidistantes do centro, como afirmar novas verdades além de que essa periferia é por toda parte semelhante a si mesma, uniforme, etc? Quando digo que estamos aqui nos quadros do problema do uno e do múltiplo, quero com isso significar que a resposta dessas questões depende da solução de um problema que diz respeito a todos os juízos em geral, a priori ou não. Com efeito, é preciso compreender - conforme um conhecido exemplo aristotélico, mas que é análogo ao do círculo já mencionado - como é possível que de um homem, definido como animal racional, possa também ser verdadeiramente afirmado que é branco, andante, dotado de certas quantidades, e muitas outras coisas que não estão na definição, sem que isso equivalha a afirmar, numa estrita contradição, que ele é ao mesmo tempo homem e não-homem.

A solução aristotélica, como se sabe, procura romper com a concepção "rígida" ou unívoca do "ser" uno e único de Parmênides, sem, contudo, pôr a perder a principal conquista do eleata: o princípio de não-contradição, princípio primeiro e supremo da lógica clássica. E Aristóteles procura fazê-lo, entre outros recursos, pela doutrina das categorias, que preside a inclusão da terceira cláusula em sua reformulação da versão parmenídica do princípio de não-contradição - a cláusula kata to auto, ordinariamente traduzida como "no mesmo sentido" - e que lhe permite afirmar que o mesmo Sócrates, ao mesmo tempo, é homem e é branco, ou seja, algo além de sua definição, sendo, pois, homem e não homem... mas não no mesmo sentido de "ser". A terceira clausula do princípio de não contradição, ou cláusula categorial, estipula que a um mesmo sujeito pode ser atribuído e não atribuído, ao mesmo tempo, um mesmo predicado, desde que a atribuição, expressa pela cópula "é", se dê em distintas 
categorias, ou seja, que o "e" designe distintas formas de envolvimento, de sorte que Sócrates seja homem na categoria da quididade mas seja branco, e não homem, na categoria da qualidade.

Além das inúmeras censuras que Espinosa dirige a Aristóteles, que tornam a intenção de aproximá-los um tanto inesperada, tal aproximação, colocada sem maiores precisões a partir do contexto supra descrito, envolve pelo menos dois problemas preliminares. Em primeiro lugar, é a distinção geral entre substância e acidente que serve de recurso para Aristóteles no caso em pauta, pois é acidental que um homem, enquanto homem, seja branco, não sendo pela definição de homem que isso pode ser conhecido, ao passo que Espinosa está sendo instado a explicar a possibilidade de uma dedução a priori - a partir da Extensão enquanto Extensão — de novas verdades desconhecidas (e mais ainda, através disso, a possibilidade da dedução necessária do mundo físico a partir da essência de Deus). Em segundo lugar, a admissão por Espinosa de essências individuais, suas críticas à interpretação realista de universais abstratos como "homem", a recusa de um estatuto ontológico positivo para a contingência e a redução desta última a uma limitação cognitiva do intelecto finito, interditam liminarmente um recurso espinosano à distinção entre substância e acidente nos mesmos termos em que Aristóteles o faz ${ }^{299}$. Todavia, isso não exclui a possibilidade de também encontrarmos no sistema espinosano uma ruptura com a concepção rígida e unívoca do "é" parmenídico, bem como uma conseqüente multiplicidade de sentidos para a cópula, presidindo a problemática que procurei delinear a partir da correspondência com Tschirnhaus. No que segue, procurarei demonstrar não só que essa linha de interpretação é plausível, como também que pode ser bastante promissora no esclarecimento das respostas de Espinosa para as questões que Tschirnhaus lhe dirigiu.

\section{3) - O problema do uno e do múltiplo e a teoria espinosana dos modos de percepção.}

299 Mas isso não exclui o recurso à distinção substância/modo, que vai presidir outras articulações categoriais, tais como as do Deus quatenus. É de notar justamente que o ente não se divide entre ente e não-ente (o nada) pois que isso, ou bem fazendo do nada algo, ou bem dividindo sem dividir, seria absurdo. Em Espinosa, os modos não são acidentes de uma substância, são afecções que não tem existência separada dela, muito embora não deixem de ser reais, visto justamente que são modificações de uma coisa real. O movimento, segundo Espinosa, é ele próprio uma modificação da substância, o que está de acordo com a caracterização do modo infinito imediato como sendo - note-se a retomada da problemática da seção Cf. do Capítulo anterior — as leis do movimento e do repouso. Os modos, sejam eles infinitos, imediatos, mediatos ou finitos, são modificação necessárias da substância em que inerem (i.e. são em), o que exige uma transformação na própria relação de inerência. 
Tschirnhaus - e muitos outros leitores - reconhecem que as respostas de Espinosa são desagradavelmente lacônicas. Penso, porém, que elas são, antes, maximamente concisas, e que levam em conta o fato de que seu interlocutor já dispunha de textos da Ethica e de teses centrais do De Emendatione.

Tomemos primeiramente suas respostas sobre a dedutibilidade do múltiplo físico a partir da Extensão imóvel e indivisível. A primeira resposta de Espinosa, na carta 81, conquanto breve, é inequívoca em sua afirmação de que, dependendo de como se conceba a Extensão, a demonstração a priori da individuação, conservação e diferenciação constitutivas da multiplicidade física é não apenas difícil mas impossível. Por isso, considera que Descartes concebeu mal a Extensão como massa em repouso, pois uma matéria que está em repouso, tomada apenas em si mesma, assim permanecerá, exceto pela intervenção de uma causa externa mais potente; razão pela qual, segundo Espinosa, “os princípios cartesianos das coisas naturais são inúteis, para não dizer absurdos".

Na carta 82, Tschirnhaus não se dá por satisfeito com a resposta, que não diz direta e positivamente a posição espinosana, suspeitando que isso se deva a temas mais delicados aí pressupostos, nomeadamente, uma possível recusa por Espinosa da hipótese cartesiana de Deus como motor, ou seja, de um Deus que desempenhasse a função da referida "causa mais potente externa" e cuja causalidade superaria a capacidade de compreensão humana. Diante disso, na Carta 83, Espinosa fornece uma derradeira resposta, compactando muito sua efetiva posição. Por um lado, praticamente repete o que dissera, escrevendo que Descartes definiu mal a matéria pela extensão, mas por outro, afirma que a matéria deve ser explicada por meio de um atributo que exprima uma essência eterna e infinita. A chave da resposta é a noção de atributo.

$\mathrm{Na}$ definição 4 de Ethica I, o atributo é definido como "aquilo que o intelecto percebe da substância como constituindo a essência dela / id quod intellectus de substantia percipit tanquam ejusdem essentiam constituens". Há, nesta definição, dificuldades na compreensão do papel desempenhado pelo substantivo intellectus, pelo verbo percipit, pelo advérbio tamquam e pelo particípio presente constituens, em suas relações com a noção de essência da substância. A partir de leituras eminentemente epistemológicas, já foi pretendido, por exemplo, que o atributo existiria apenas no contexto de uma relação cognitiva do intelecto com a substância, posto que a definição fala de uma percepção do intelecto e que, além disso, o advérbio tamquam parece enfraquecer uma leitura realista 
do particípio constituens. Em outro sentido, como Leibniz chegou a observar a partir de suas anotações à Ethica, parece decorrer daí uma contradição entre a conceptibilidade per se da substância (na definição 3) e a concepção de sua essência através dos atributos pelo intelecto. Ademais, num registro ontológico, a definição supostamente pecaria por fazer o atributo, que é uma realidade infinita em seu gênero, depender do intelecto, entendido como uma realidade finita e dependente daquela primeira, criando uma desproporção ontológica e uma interdependência circular. Frente a isso, minha hipótese é de que se faz necessária uma interpretação lógica, ou melhor, ontológico-categorial, segundo a qual, nessa definição, "percepção" dever significar afirmar ou negar, e a referência ao intelecto deve significar a estipulação de uma maneira específica de afirmar, pela qual se determina um pertencimento constitutivo de algo a algo, isto é, no caso da def. 4, do atributo à substância. Não se trata de dizer que toda afirmação intelectual concerne apenas à relação constitutiva entre a substância e o atributo (ainda que a recíproca seja verdadeira: toda relação entre a substância e seus atributos é uma cópula causal constitutiva), pois há intelecção do modo, do qual o intelecto conhecerá a essência particular afirmativa como sendo a cópula imanente (i.e. constitutiva) entre uma atividade e o seu resultado, tal como exemplifica a gênese da esfera. Assim, intellectus, no contexto da definição 4 de Ethica I, qualificaria o tipo específico de cópula correspondente a uma relação de constituição, cuja forma precisa - a forma do verdadeiro ou adequação - a teoria espinosana da definição genética vem explicitar.

Em favor dessa interpretação, eu recordo que por várias vezes o De Emendatione que bem pode ser chamado "a lógica de Espinosa" - ensina que "é” e "não-é" possuem várias formas. O proêmio do tratado, por exemplo, ensina, num contexto ético, que os conteúdos ordinariamente buscados na vida comum são, ao mesmo tempo, bens verdadeiros e males certos, mas não no mesmo sentido, e que, num terceiro sentido, não são nem mesmo bons ou maus. Mas é a doutrina dos modos de percepção que constitui a peça de resistência da presente interpretação, pois esses modos são aí caracterizados justamente como diferentes maneiras de afirmar ou negar algo, dentre as quais encontra-se justamente a idéia adequada ou definição perfeita, que caracteriza a forma propriamente intelectual de afirmação. Talvez se queira insistir na diferença entre "afirmar algo", que é o que Espinosa aí diz da percepção, e "afirmar algo de algo", que é o que diz Aristóteles da predicação. Mas, no mesmo tratado, Espinosa emprega como sinônimos "conceito" e "definição" [\$96] e sobre o conceito escreve: "conceito, isto é, 
idéia ou coerência do sujeito e do predicado na mente" [§62]. Ademais, no escólio da proposição 49 de Ética II , Espinosa interroga: “Que é perceber um cavalo alado senão afirmar asas de um cavalo?", formulação em que estão patentes tanto a equivalência entre perceber e afirmar quanto a forma "algo (asas) de algo (cavalo)", num contexto em que, na falta de idéias contrárias, essa afirmação também se afigura como a consideração - no caso, falsa — de objetos existentes no mundo.

A esse propósito eu lembraria, da parte de Aristóteles, a discussão por ele entabulada, em Física I, 2, 185b25 ss, contra aqueles que, como certo Licofronte, ingenuamente suprimiam o verbo "é" para evitar que algo uno se tornasse múltiplo quando dissessem, por exemplo, "o homem é branco", preferindo "homem branco", ao passo que outros, pelo mesmo motivo, preferiam fórmulas como "embranqueceu", ou “caminha” em lugar de "é caminhante”. Como ensina Francis Wolff, esse temor "supõe que o uno ou o ente sejam tomados de um único modo", temor do qual Aristóteles se livra porque sabe que, por um lado, malgrado a linguagem, em "homem branco" — ou em "cavalo alado" - o "é" está presente, mas também que, por outro, "é" se diz em muitos sentidos. Ademais, para o Estagirita, o "ser" e o "não ser" não significam uma coisa interposta entre o sujeito e o predicado, mas co-significam uma articulação que se considera existir entre eles e que sem eles não se compreende. Em termos espinosanos, como foi dito, afirmação e negação significam certa conexão entre as idéias e, ao mesmo tempo, a asserção - por vezes falsas, como em "cavalo alado" — de que tal conexão existe entre as coisas. Cabe, então, considerar os modos de percepção, enquanto modos de afirmar e negar, como modos de articulação ou cópula (que estimo ser o sentido amplo do termo cohaerentia usado por Espinosa) dotados, ademais, de alguma dimensão referencial.

Destarte, uma das maneiras - certamente não exaustiva, mas pertinente e relevante - de descrever os modos de percepção pode ser, muito sumariamente, a seguinte:

(i) - Na imaginação, dois elementos $(A$ e $B)$ se associam entre si na medida em que se associam a um terceiro $(C)$, como por exemplo, no caso do conhecimento por sinais, o som articulado "maçã $(A)$, um certo fruto $(B)$, e o corpo do homem afetado por ambos simultaneamente $(C)$; ou ainda, no caso da experiência vaga, um latido $(A)$, um cão $(B)$, e o corpo de um homem $(C)$ que simultaneamente os percebe e afirma mesmo sem tirar uma conclusão formal — "o cão é um animal que late". 
(ii) — Na razão, dois elementos $(X$ e $P)$ se compõem como causa ou coisa $(X)$ e efeito exclusivo ou propriedade exclusiva $(P)$ sempre concomitante a um universal $(F)$, como, por exemplo, no raciocínio que conclui que, se um numero $X$, numa série de 4, possui a propriedade $P$ de ter seu produto pelo primeiro igual ao produto do segundo pelo terceiro, então ele é um caso de quarto proporcional $(F)$. Trata-se, pois, da relação entre um sujeito $(X)$ e os seus $\iota \delta\llcorner\alpha$ ou propria $(P)$, ou seja, propriedades que, embora sejam conversamente predicáveis, sempre, somente e de todas as coisas de uma mesma espécie $(F)$, nem por isso fornecem a compreensão adequada de por que essa coisa é o que é. Assim, por exemplo, se uma figura $\mathrm{X}$ possui a propriedade $P$ de ter todos raios iguais, então $X$ é um círculo $(F)$, e conversamente, se a figura $(X)$ é um círculo $(F)$, então tem todos os raios iguais $(P)$. Mas, como já ensinava a tradição aristotélica, embora o círculo só seja círculo com $P$, não é círculo por P (est cum hoc, sed non propter hoc, como se dizia nas disputas medievais). A introdução de uma relação que exprime causa ou razão (propter) evidencia a assimetria e a insuficiência do proprium frente à essência, embora o proprium seja eficaz na lida meramente extensional com $X$, permitindo sua subsunção a classes e a criação de uma linguagem estável. E é de notar que, no De Emendatione, esse modo de percepção seja referido aos matemáticos, em perfeito acordo com o que Tschirnhaus dissera sobre, "nas matemáticas, [sermos] capazes de deduzir uma única propriedade a partir de uma coisa qualquer considerada só em sua definição". E de fato, por este modo, o sujeito $X$ figura como um suporte, um aliquid que tem a propriedade $P$ e que, por isso, será incluído na classe dos $F$. Concebido dessa maneira, $X$ nada é de positivo senão este seu único predicado $P$, e de um tal $X$, evidentemente, nada pode ser deduzido exceto $P$, e de modo algum múltiplas propriedades, e muito menos infinitas, como afirma a proposição 16 de Ethica I. A partir de uma tal definição pela propriedade, querer saber qualquer outra coisa a mais do que a propriedade mesma é ir do menos para o mais e aceitar que algo vem do nada, infringindo o princípio de razão suficiente e, finalmente, o de não contradição.

(iii) - No modo intelectual de percepção, da-se justamente a introdução de uma relação que exprime causa ou razão para articular os elementos X e P. Aqui não é tão fácil extrair dos textos espinosanos a modelagem da articulação ${ }^{300}$. Mas basta, de

${ }^{300}$ Em um artigo publicado nos Cadernos de História e Filosofia da Ciência da Unicamp, de jan-jun de 2004, publiquei uma primeira tentativa de descrever essa modelagem, com base na solução da quarta proporcional através de uma versão genética do procedimento euclidiano chamado Antyphairesis. 
início, reconhecer que Espinosa é explícito ao dizer, no De Emendatione, que "A definição, para que seja dita perfeita, deve explicar a essência íntima da coisa, e cuidar para que em seu lugar não usemos próprios" [\$95]. Tal definição será a "que compreende a causa próxima" ou "que expressa a causa eficiente". Apenas através dela, insiste Espinosa, é possível "deduzir todas as propriedades de um sujeito". E a razão disso pode ser vislumbrada na nova formulação que a definição do círculo consequentemente adquire: "o espaço descrito por uma linha qualquer, da qual um dos extremos é fixo e o outro, móvel". O que muda com essa reformulação no que concerne à relação entre o sujeito $(X)$ e seu proprium $(P)$ ? É preciso notar, antes de mais nada, que os raios iguais da definição anterior são a linha em movimento usada nesta definição, o que se verifica pelo fato de que aquela igual medida dos raios, presente na definição pelo proprium, mede o quanto medir esta linha da definição causal. Assim, o raio igual $(P)$ toma parte na definição do espaço ou figura $(\mathrm{X})$, mas agora está unido e se afirma deste último ao modo de um elemento constitutivo, o que acontece justamente por causa do movimento numa das extremidades da linha e do repouso na outra. O movimento e o repouso, organizados numa determinada proporção, é que fazem com que a "linha qualquer" se torne "raio". A definição genética é precisamente a narração desse evento, que explica como e por que o círculo, sendo o que é, tem o proprium que tem. Passa-se de uma relação de inerência marcada pela idéia de posse, conotada pelo termo propriedade, para uma relação produtiva, conotada pelo verbo descrever (describitur). E com proveitoso jogo de palavras, eu gostaria de dizer que passa-se aqui de uma descrição como atribuição de propriedades para uma descrição como procedimento ou atividade construtiva, atividade cujo resultado - para emprestar uma fórmula de Matheron - "não é outra coisa que a atividade ela mesma: ele é simplesmente a estrutura que ela se dá ao se desenvolver". Destarte, a apresentação do esquema construtivo do círculo, porque permite construir um círculo, permite, ipso facto, a obtenção de todas as propriedades que um círculo necessariamente possui.

Como se pode ver por minha caracterização dos primeiros modos de percepção, não julgo ser indevido falar de alguma predicação na lógica de Espinosa; julgo indevido, isto sim, desconsiderar as peculiaridades do modo intelectual de afirmar ou negar, peculiaridades que parecem levar a idéia de predicação às suas fronteiras mais remotas ou, quem sabe, talvez até a transpô-las, transformando-a noutra coisa. Na cópula intelectual, o sujeito $(X)$ não desempenha o papel de uma lacuna que precisa ser 
preenchida por conteúdos, nem de um suporte ou um de alvo para a atribuição de predicados, de sorte que a presença do intelecto na definição do atributo me parece significar, por assim dizer, a correção (a emenda?) do sentido ordinário - e até mesmo etimológico — da idéia de atribuir. A presença do intelecto indica não somente que a relação de inerência deve substituída ou repensada como uma relação de constituição, mas sobretudo que se trata aí de uma constituição dinâmica, ou melhor, de uma atividade constitutiva. Enquanto relação de constituição, a cópula intelectual significa que a propriedade não está sendo afirmada de algo subjacente, isto é, de um sujeito que, por si só, já estivesse dado e completamente especificado em sua essência, independentemente dessa afirmação. Por isso, embora seja verdadeiro dizer que predicados estejam sendo atribuídos a um sujeito, eles não se atribuem de algo distinto que já estivesse subjacente e pudesse constituir-se em sua essência sem tais predicados. E isso é exatamente o que se deve dizer - como de fato diz Lucas Angioni em sua Introdução à teoria da predicação em Aristóteles — das propriedades substanciais, ou melhor, que se predicam de um sujeito na categoria da quididade. É posição aristotélica considerar que os atributos, afirmados da substância na categoria da quididade, não estão na substância como em um sujeito subjacente, visto que constituem sua essência. Mas, ainda que, quanto à relação de constituição, os atributos espinosanos possuam uma notável semelhança com as propriedades quiditativas aristotélicas, há um papel crucial desempenhado na modelagem definicional espinosana pela causa eficiente, que, para Aristóteles, parece ser externa à unidade complexa entre matéria e forma, que a definição, de certa maneira, reproduz num nível lógico através do gênero e da diferença. Para Espinosa, em razão da causa eficiente na definição, aquilo que a pergunta "o que é?" quer saber quando formulada no modo intelectual, deve vir respondê-la sob a forma da narração de uma atividade constitutiva, de uma gênese, ou talvez até mesmo de um procedimento, como se observa pelo uso do movimento, do repouso e da linha na definição do círculo. E isso tem muitas conseqüências. Concluirei comentando apenas duas, que incidem no contexto da correspondência com Tschirnhaus.

\section{4) - Remate}

A primeira consequiência é que, em razão dessa forma de constituição, o atributo e a substância tornam-se profundamente inseparáveis, ao ponto de Espinosa os tratar — na Ethica e alhures - como sinônimos. Os atributos não pertencem à substância como, para os matemáticos, a igualdade dos raios pertence ao círculo, isto é, por força de uma 
cópula do terceiro modo de percepção. Eles estão muito mais intimamente conectados! É isso que Tschirnhaus não compreende. E entendo ser por isso que a proposição 5 de Ethica I ("Na natureza das coisas não podem ser dadas duas ou mais substâncias de mesma natureza ou atributo") se demonstra dizendo que, se substâncias se distinguissem pela diversidade dos atributos, conceder-se-ia ser dada somente uma do mesmo atributo. Não parece ser por acaso que Leibniz — amigo Tschirnhaus — se interessará especialmente pela proposição 5. Afinal, esta proposição está no centro da demonstração da unidade e unicidade substanciais, pois é porque, de um lado, substâncias não partilham atributos, e porque, de outro, Deus é o ente absolutamente infinito, do qual nenhum atributo que exprima uma essência pode ser negado, que se segue que "afora Deus, nenhuma substância pode ser ou ser concebida".

A segunda conseqüência é que a modelagem eficiente da cópula intelectual institui uma base para a posterior qualificação da essência da substância única — os atributos - como essência actuosa ou Natureza Naturante, contrariando o suposto imobilismo eleata que se esperaria encontrar associado à tese da unidade substancial. A causalidade eficiente imanente está embutida na essência da substância já pela presença do intelecto na definição de atributo. E não é outra coisa o que Espinosa diz a Tschirnhaus, na carta 60, quando recusa a definição de Deus como "ente sumamente infinito", pois, como confirma o Breve Tratado, isso não é senão um proprium, em contraste com o qual Espinosa contrapõe sua definição de Deus como substância dotada de infinitos atributos expressivos, designando-a explicitamente como uma definição pela causa eficiente interna! Mas, afinal, por que essa definição é dita envolver a causa eficiente? A resposta me parece estar na cópula intelectual, que caracteriza o atributo não só como propriedade quiditativa mas sobretudo como atividade constitutiva.

É por isso que se pode afirmar, a priori, que da essência da substância algo se segue (sequitur), e que, se essa essência é constituída por uma infinidade de atributos infinitos em seus gêneros, infinitas coisas daí devem seguir-se como infinitos modos desses atributos (como dizia a proposição 16 de Ethica l). E esses modos, por sua vez, serão expressões da essência actuosa, por via de seus respectivos atributos, de sorte que nada haverá na Natureza de que não se siga algum efeito. A Natureza, para Espinosa, não é a infinita esfera homogênea a que o ente é comparado por Parmênides; nem a matéria é a extensa massa inerte, ativada desde fora, concebida por Descartes, mas um eterno e infinito comercio causal, maximamente complexo. É precisamente o 
funcionamento desse comercio que a pequena física de Ethica II poderá, então, descrever segundo as leis do movimento e do repouso. E se observarmos que, na Carta 32, para Oldemburg, esse comércio causal entre as partes - pelo qual elas acomodam ou divergem entre si segundo as leis de suas naturezas - é o que Espinosa diz entender por coerência, teremos, então, mais um bom indício de que os modos de composição dos entes físicos devem ser isonômicos aos modos da cópula, compreendendo, pois, causalidades inadequadas, propriedades comuns, e essências afirmativas.

Se, ao longo da troca epistolar, os desentendimentos de Tschirnhaus parecem crônicos, quer na via física, quer na via lógica em que os homens andam às voltas com o uno e o múltiplo, julgo haver sido porque o missivista não soube compreender a tese espinosana de que "ser" se diz em muitos sentidos.

A precisão de sentido que deve ser feita quanto aos conceitos de essência e definição, diz respeito a formulações como: "a Extensão em si mesma considerada (in se spectata)". Como dirá explicitamente Espinosa, tudo depende de como se conceba a extensão: se for como massa inerte, de nada servirá para explicar as gerações e os movimentos supostos pelo objeto formal da física, pois o não-movimento não pode causar o movimento. Mas a questão lógica é mais precisamente a seguinte: o que, afinal, pode ser sabido da coisa tomada em sua definição? Considerá-la assim é o mesmo que considerar um coisa em si mesma? Considera-la de alguma dessas duas formas é o mesmo que conhecer sua essência? Os conceitos são distintos mas ao mesmo tempo tendem a se recobrir. Há o que pensar. Em todo caso, se, como foi dito anteriormente, o ente é o nexo entre uma causa e um efeito (que será novamente uma causa e um efeito, etc. ad infinitum), e se é esse nexo que a definição genética deve determinar no pensamento, então, considerar uma coisa somente em sua definição não significará considerá-la "isoladamente", visto que sua natureza é a da articulação. Se a expressão "considerar uma coisa em si mesma" significar o mesmo que "considera-la isoladamente", então, considerar uma coisa em si mesma (in se spectata) será, ao invés de defini-la, abstraí-la (noção que não deixa de estar sugerida pela expressão spectare, que comporta o sentido de um olhar que considera e desconsidera, que enfoca, que estabelece diferenças). E considerar a coisa em sua essência ${ }^{301}$ ?

301 Parece-me que, para Espinosa, talvez fosse o caso de fazer uma diferença entre o que pertence à definição e o que pertence à essência de uma coisa. Pois Deus não pertence à essência de uma coisa (Eth. II P10 scol.), mas nada pode ser concebido sem ele (Eth. I Cf.), e o conceito de uma coisa é sua definição (TIE).. A presença de Deus na definição de um modo ou de um atributo é a presença da causalidade atuando sobre o termo médio. A presença de Deus nas definições adequadas ocupa a função 
Eu tenderia a pensar que nenhuma dessas "considerações" - em si, na sua definição, em sua essência - corresponde a uma abstração que isole a coisa de seu contexto causal, pois não pensa-la sob a ordem dos encontros fortuitos (que é como a série infinita de causas finitas surge aos olhos de uma mente finita) ainda é pensá-la como um modo finito que é parte de um modo infinito mediato, etc... como modo da Substância. Nesse sentido, a ontologia de Espinosa se me afigura como uma ontologia da ordo et conexio: ser é conexão. Há conexão inclusive para explicar o ser de Deus: ele é causa de si no mesmo sentido em que é causa de todas as coisas. Ele não é Deus se não causar seus modos, pois que é causando-os que ele causa a si (visto que ser causa-de-si jamais foi uma coisa fazer-se a si mesma a partir do nada). É disso que Espinosa me parece haver falado na Carta 6 (que não comentei ainda): da "conexão entre a causa primeira e as coisas finitas". E o interessante é que Espinosa diz, nessa carta, que trata disso em um escrito sobre a emenda do intelecto que está redigindo. Os comentadores se batem para saber o que isso significa do ponto de vista da composição das obras, posto que o De Emendatione aparentemente não trata do assunto. De minha parte, acho perfeitamente plausível tomar a teoria dos modos de perceber como uma teoria dos modos de pensar conexões: a imaginação é determinada por conexões associativas de diversos tipos, a razão opera com conexões necessárias mas não conhece coisas singulares, e a intuição age ou efetua no pensamento uma conexão singular em ato, que é, ela própria, como essência formal ou modo do pensamento, um sintagma causal concreto das leis eternas da natureza. E sendo isso, a idéia intuitiva conhece em si mesma tudo que ela pode conhecer de seu objeto, visto que a mente jamais terá olhos para ver o corpo (como exige a diferença de gênero entre os Atributos).

Aliás, isso também me permite comentar o ponto importante da correspondência que ficara faltando: Tschirnhaus, na Carta 59, descreve o processo de obtenção da idéia adequada e sua relação com a causalidade como uma inquirição das causas e das causas das causas da idéia, até atingir uma causa "da qual não pudesse ver outra causa", e não como a construção de uma idéia que exprime, enquanto idéia, a causa eficiente do objeto (como dirá Espinosa na resposta, a propósito da idéia adequada do círculo: "inquiro se essa idéia envolve a causa eficiente do círculo"). Ademais, Tschirnhaus indaga "se há um meio de saber qual [idéia] deve ser preferencialmente usada" dentre várias idéias adequadas da mesma coisa, como no caso do círculo (que Tschirnhaus 
considera ser adequadamente definido tanto pela igualdade dos raios quanto por outras propriedades), pois julga que a dedução total pode dar-se mais facilmente a partir de uma do que de outra. Ora, como vimos, Espinosa responderá que a idéia ou definição deve expressar a causa eficiente e que dela devem ser deduzidas todas as propriedades, etc. Mas faltou que eu dissesse o que Espinosa responde acerca do problema da equivalência entre definições (análogo ao bem conhecido problema da equivalência das hipóteses na astronomia):

"afirmo absolutamente que de certas propriedades de uma coisa (seja qual for a idéia dada) algumas coisas podem ser descobertas mais facilmente e outras com grande dificuldade, ainda que digam respeito à natureza dessa coisa"

Quanto a essa resposta, concordo com a leitura que Marilena Chaui faz em $A$ Nervura do Real:

"se pretendemos ter uma idéia adequada (não importa se de uma figura geométrica ou de um ente físico, isto é, "seja qual for a idéia dada"), "a única regra a seguir" (para a idéia adequada) é buscar uma idéia da qual "se possa extrair tudo" (ex qua omnia elici) e considerar que, "se alguém deduzir de alguma coisa tudo quanto possa ser deduzido dela", necessariamente o que vier por último será mais difícil do que o que vier primeiro, não porque a primeira idéia seja mais simples do que as últimas, mas, pelo contrário, porque da complexidade da primeira idéia devem resultar todos os efeitos e propriedades cujo conhecimento será mais difícil já que a concatenatio será cada vez mais particular e cada vez mais exigente do conhecimento de outros particulares. Em outras palavras, o ponto de partida complexo é ut absolute, enquanto o ponto de chegada será cada vez menos complexo e mais relativo, porque será uma essência particular que depende de múltiplas conexões causais que são, por seu turno, dependentes de muitas outras"302

Felizmente, o ponto que deixei passar me é favorável. Pois, como já tive ocasião de dizer ha mais tempo, meu entendimento também vai no sentido de considerar que:

“a forma - a formação — da verdade é, num só passo, construção e legitimação. De fato, tomada separadamente de sua causa e do todo que com ela se

${ }^{302}$ Op. Cit $\mathrm{p} 701$. 
compõe na conjunção resultante, a afirmação do movimento no semicírculo seria absolutamente falsa, pois teria sua natureza íntima, por assim dizer, 'posta para fora', como se tal causa não fosse a sua causa e tal resultado não fosse o seu resultado. Isolada, por isso, de si mesma, essa afirmação do movimento no semicírculo seria uma idéia mutilada e truncada, na qual seus elementos constitutivos não estariam, no sentido forte do termo, constituindo nada, porque permaneceriam apenas justapostos. Mas, conjugada ao conceito de esfera ou de alguma causa que a determina, a afirmação do movimento no semicírculo será verdadeira, e a idéia assim formada, mesmo envolvendo vários elementos articulados sob a forma de uma estrutura particular em atividade, será chamada, por Espinosa, de idéia simples, (...) É isso que Tschirnhaus não percebe quando opõe, de um lado, a definição e, de outro, sua articulação com uma multiplicidade de elementos, pois, para Espinosa, ela é a conexão na qual se articula uma multiplicidade de elementos, os quais hão de ser novamente complexos, ao infinito (...) O intelecto é uma força que, por exemplo, ao pensar o movimento e o semicírculo na conexão que assim se produz, abarca esse pensamento no conceito conectivo efetivamente pensado, a saber, o de esfera. Essa força, julgamos nós, assemelha-se à força de nomear: chamo o que assim foi produzido de esfera! Trata-se, porém, como já se compreende, da força de pensar, isto é, de produzir conceitos, de ter essências objetivas, idéias verdadeiras que, como tais , sempre convêm a um ideado no ser",303

303 Rezende, C.N. "Imanência e conhecimento verdadeiro; o conceito de emendatio na teoria do conhecimento de Espinosa: um estudo sobre o Tractatus de Intellectus Emendatione", Relatório final para Exame de Qualificação, 1999, pag. 46. 


\author{
CAPÍTULO IV \\ Essência e Propriedade \\ no Tractatus de Intellectus Emendatione
}

\title{
4.1) Tábua dos modos de percepção
}

Há um núcleo temático na filosofia espinosana, concernente às estruturas e processos ("maneiras", "modos", "gêneros”) em que a cognição humana se organiza, que comparece explicitamente no Breve Tratado, no Tratado da Emenda do Intelecto e na Ética, além de participar, de maneira mais ou menos indireta, da maioria dos outros escritos de Espinosa, desde os mais antigos aos da derradeira maturidade. Sua permanência em épocas e textos distintos indica a importância que o autor lhe conferia, bem como seu enraizamento essencial no interior do sistema.

É certo que há diferenças entre as três principais exposições da doutrina nas obras acima referidas, mas é preciso admitir - aqui em conformidade com o que predomina na numa exposição são basicamente os mesmos que seus recíprocos nas demais, e que as diferenças textuais, embora possam manifestar variações filosóficas relevantes, não são, em sua maioria, reais inconsistências. As diferenças mais evidentes concernem (i) ao número de processos discernidos (3 no Breve Tratado e na Ética e 4 no Tratado da Emenda, embora naquelas obras também haja uma oscilação entre 3 e 4), (ii) à rubrica que os engloba ("maneiras de conhecer" no Breve Tratado, "modos de percepção" no Tratado da Emenda, e "gêneros de conhecimento" na Ética), e (iii) à efetiva caracterização que cada processo recebe no texto em que radica. Um usual quadro sinóptico pode, para os fins desta introdução, organizar esses dados a contento: 


\section{Breve Tratado}

\section{"Maneiras de conhecer}

(manier van kennisse)"

\section{Por fé simplesmente (enkelyk door Waan) ou opinião (Opinie), que se origina: (1.1) por experiência (door ondervinding) ou}

(1.2) por ouvir dizer (door hooren zeggen).

Obs.: Tanto em 1.1 quanto em 1.2, não produz conhecimento necessário, pode errar, é duvidosa; dá lugar ao conjecturar (gissen) e ao presumir (meynen) mas não à certeza. Sob a forma 1.2, está sujeita à mentira dos testemunhos, bem como às demais insuficiências que decorrem da condição extrínseca do signo frente àquilo a que se reporta. Sob a forma 1.1, fracassa ao pretender uma regra (regul) ou conclusão (que pode não ser formal) de validade universal. Não obstante, a experiência produz certa união e fruição interior do objeto experimentado; lida com o particular.

\section{Por crença verdadeira (door Waar Geloof), verdadeira Razão (waare Reden) ou convicção racional (betuyginge van Reden)}

Obs.: Não pode errar, produz conhecimento necessário; obtém racionalmente uma regra; lida com propriedades; realiza a dedução (gevolge) de uma coisa a partir de outra distinta; chama-se crença porque aquilo que conhece não é visto, embora seja conhecido com verdade (waarlyk) porque deve ser (behoort zyn, moet zyn) necessariamente um tal e não outro; obtém uma conformidade (sodanig) com a coisa exterior, isto é, corresponde (overeencomt) a ela, mas não produz a interiorização do que a coisa verdadeiramente é (wat waarlyk is); não produz união com a coisa, que perdura como exterior (buyten), e por isso, ainda que vença a força dos testemunhos (1.2), encontra dificuldades em vencer as opiniões empíricas (1.1) e as paixões delas nascidas; dá origem ao conhecimento do bem e do mal e do verdadeiro e do falso; não é o mais excelente, mas antes uma escada (trap): só é boa enquanto uma via (weg). 


\title{
3. Por saber claro e distinto (door klaare en onderscheide Kenisse)
}

Obs.: Não pode errar; não deriva do testemunho, da experiência, nem da arte de raciocinar (kunst van reden); vê diretamente (terstond, onmiddelyk) por intuição; é estar unido à coisa mesma, senti-la (gevoelen) e fruí-la (genieten); a união aí produzida é análoga à da mente com o corpo, e quando ela se dá com o ente perfeitíssimo, proporciona como que um segundo nascimento; por esse conhecimento, vivemos dentro de nosso elemento (element); ele supera em muito a maneira anterior de conhecer.

\author{
Tratado da Emenda, \\ "Modos de percepção \\ (modi percipiendi)"
}

\begin{abstract}
1. Por ouvir (ex auditu) ou por algum signo (ex aliquo signo) arbitrário (qui vocant ad placitum)
\end{abstract}

Obs.: Pode perdurar sem suscitar dúvida (numquam dubitavi); aplica uma operação memorizada, originalmente ouvida, de um mestre por exemplo, nua (nudam), sem demonstração (sine demonstratione); compõe palavras na memória a partir das disposições do corpo; não procede na devida ordem; é um modo de percepção muito incerto e que nada percebe da essência das coisas, nem tampouco de sua existência singular (singularis existentia), porquanto o conhecimento desta depende do conhecimento daquela; ademais, o simples ouvir, quando não presidido por uma intelecção (ubi non prascessit proprius intellectus), não pode vencer os afetos (nunquam quis poterit affici); constitui palavras arbitrariamente (ad libitum) e segundo a concepção do vulgo (captum vulgi); as constitui como signos (signa) do que está na imaginação e não no intelecto; provém da afecção de coisas corpóreas; impõe nomes negativos ao que é positivo e vice-versa; permite negar ou afirmar em decorrência da natureza das palavras e não por causa da natureza das coisas; liga-se à produção das idéias fictícias, falsas e dúbias; corresponde a uma mente passiva; bem como a uma falta (defectum) de conhecimento.

2. Por Experiência vaga ( $a$ b experientia vaga), isto é, por uma experiência não determinada pelo intelecto (non determinatur ab intellectu) 
Obs.: É dita vaga e não determinada pelo intelecto por que ocorre por acaso (casu occurrit), permanecendo inabalada (inconcussa), por ausência de um experimento (experimentum) que a refute (oppugnat); afirma algo em virtude da percepção de semelhanças (similis) entre coisas ou acontecimentos que não são idênticos; procura formar axiomas universais a partir do êxito em casos simples e patentes (onde o resultado per se patet), concluindo ser sempre boa a operação que produz o mesmo resultado que, sem a mesma operação, fora obtido nesses casos; é um processo muito incerto e sem fim (sine fine); nada percebe nas coisas naturais (in rebus naturalibus) exceto acidentes (prater accidentia), que jamais são entendidos claramente se as essências não o forem previamente; liga-se à produção das idéias fictícias, falsas e dúbias; não procede na devida ordem; provém da afecção de coisas corpóreas; não discerne o conhecido do desconhecido (notum ab ignoto) dentre o múltiplo presente nessa percepção; corresponde a uma mente passiva, bem como a uma falta (defectum) de conhecimento; provê quase todo conhecimento concernente ao uso da vida (ad usum vitæe). Mas a descrição deste modo deixa entrever, mediante a especificação da experiência como "não determinada pelo intelecto", a noção complementar de uma 'experiência determinada pelo intelecto', que bem pode corresponder ao "experimentum" que haveria de refutar a experiência vaga; ora, esses experimentos (experimenta) são suficientes para conhecer segundo quais leis das coisas eternas uma coisa se faz e para que seja conhecida sua natureza íntima (secundum quasdam rerum aternam leges facta sit et intima ejus natura nobis innotescat); o que sugere uma conexão possível deste modo com os dois próximos

\section{Por conclusão da essência de uma coisa (essentia rei) a partir de outra coisa (ex} alia re), mas ( $\mathrm{sed}$ ) não adequadamente (non adcequate). Isso se dá:

\section{(3.1) quando a essência é concluída (concluditur) a partir de algum universal} (aliquo universali) sempre acompanhado de alguma propriedade (semper aliqua proprietas concomitatur), ou quando

(3.2) inferimos a causa (colligimus causam) a partir de algum efeito (ab aliquo effectu).

Obs.: Esse modo nada intelige da causa, além (prater) do que já fora considerado no efeito; não explica (explicat) a causa senão em termos generalíssimos 
(generalissimis terminis) ou negativamente (negative); atribui à causa, em razão do efeito (propter effectum), algo que é concebido claramente (aliquid quod clare concipitur), mas isso que conhece são propriedades (propria) e não a essência particular da coisa (rei essentia particularis); a conclusão a que chega é certa mas não suficientemente segura (talis conclusio quamvis certa non satis tuta est), a não ser aos maximamente cautelosos (nisi maxmie caventibus), que sem essa cautela caem imediatamente em erros (in errores statim incidente); concebe as coisas abstratamente (abstracte) e não pela verdadeira essência (veram essentiam); conclui sem perigo de erro (absque periculo erroris) e fornece uma idéia da coisa (ideam rei) mas por si só (per se) não é um meio que conduz à perfeição; permite, pois, a ingerência da imaginação, que concebe o que em si é uno como se fosse múltiplo (id quod in se unum est, multiplex esse [imaginatur]), separada (seorsim), confusa e abstratamente, e a isso impõe nomes, usados para significar outras coisas mais familiares, a partir das quais, então, esse abstrato passa a ser imaginando.

\section{Pela essência somente (per solam essentiam) ou pela causa próxima (per proximam causam).}

Obs.: Esse modo permitiu, ao menos no contexto do $§ 19$ (hucusque), o conhecimento de poucas coisas; vê intuitivamente (intuitive) sem fazer operação alguma (nullam operationem [faciens]); compreende a essência adequada da coisa e sem perigo de erro; mostra como e por que algo é ou é feito (ostendit quomodo et cur aliquid sit, aut factum sit); procede da causa para o efeito, como é próprio à verdadeira ciência (veram scientiam), e esse conhecimento do efeito nada mais é (nihil aliud est) do que a aquisição de um conhecimento mais perfeito da causa; não conclui a partir de abstrações mas sim de uma essência particular afirmativa (ab essentia aliqua particularis afirmativa), ou seja (sive), de uma verdadeira e legítima definição (a vera et legitima definitione), que deve explicar a essência intima da coisa (explicare intimam essentiam rei), cuidando de que seu lugar não seja usurpado por propriedades (propria) e garantindo que a mente reproduza (referre) a concatenação (concatenatio) da natureza; do conceito da coisa, ou seja, da definição (conceptus rei sive definitio), considerada sozinha e não conjuntamente com outras, esse modo deve poder deduzir todas as propriedades (concludi omnes proprietates rei); conclui a partir de uma definição afirmativa, isto é, que envolva uma afirmação intelectiva (affirmatio 
intellectiva) e não meramente verbal (verbalis); ao versar sobre uma coisa incriada, tal definição deve excluir toda causa, de modo que só o ser do objeto baste para explicá-lo (nullo alio prater suum esse egeat ad sui explicationem); ainda no caso do incriado, a definição também deve excluir a possibilidade de que, diante dela, ainda se pergunte pela existência da coisa (nullus locus manet questioni 'an sit'); e além disso, a definição do incriado também deve excluir de sua formulação substantivos que possam ser adjetivados, porque isso daria lugar a abstrações; esse modo engendra idéias especiais ou específicas, isto é, diferentemente da idéias gerais e abstratas, uma idéia clara e distinta na razão direta (specialior (...) distinctior (...) clarior) da concretude efetiva de seus objetos (isto é, das coisas particulares (cognitio particularium)); corresponde a uma mente ativa, que faz as idéias resultarem da só necessidade de sua natureza.

Ética,

"Gêneros de conhecimento

(genera cognitionis)"

\section{Conhecimento do primeiro gênero: opinião (opinio) ou imaginaçãa (imaginatio), que se dá}

(1.1) por experiência Vaga (experientia vaga) ou

(1.2) por sinais (ex signis), como por palavras ouvidas (ex auditis verbis) ou lidas (lectis).

Obs.: Tanto em 1.1 quanto em 1.2, é a origem de todas as idéias inadequadas e a única causa da falsidade (a qual não é positiva mas uma privação na idéia); permite o erro (mas a supressão deste não suprime o imaginar); contempla as coisas como contingentes; possibilita tanto a dúvida (uma flutuação (fluctuatio) da mente entre opostos) quanto a ausência de dúvidas (um repouso (acquiescentia) da mente em uma imagem por falta de oposição, diferentemente de uma positiva certeza); é capaz, quando se dá essa ausência circunstancial de causas opostas, de conservar a imagem presente de um objeto ausente ou inexistente; liga-se à memória, cujo funcionamento não está na livre potência da mente (in libera mentis potestate); não segue a ordem do intelecto; bem ao contrário, gera certa concatenação (concatenatio) mental de idéias que apenas envolvem (involvunt) a natureza dos corpos exteriores juntamente com a natureza do corpo humano, mas que não as explicam (explicant); segue, pois, a ordem das afecções suscitadas no corpo humano, determinada pelos encontros fortuitos e consolidada pelo costume (consuetudo); varia de homem para homem; liga-se ao que ocorre 
freqüentemente (scepe), muito embora, sob a forma 1.1, o que uma única experiência ensina (docet) baste para refutar aquilo que, pela frequiência ou infrequiência, ela mesma crera ser necessário ou impossível: comprova (comprobat) apenas que algo ocorre (ou seja, que não é impossível), ainda que não conheça clara e distintamente o que é isso que ocorre; produz universais a partir dos singulares representados pelos sentidos (ex singularibus per sensus representatis), mutilada e confusamente; está sujeita ao caráter limitado (limitatum) do corpo humano, capaz de formar somente um certo número de imagens simultâneas, acima do qual estas se confundem (confundunt), apagando as pequenas diferenças dos singulares (parvas diferentias singulorum); não distingue, ademais, o que ultrapassa certos limites de distâncias no tempo e no espaço. Sob a forma 1.2, também envolve a recordação (ex signis recordamur rerum); faz com que a mente, a partir do pensamento de uma coisa, caia ou incida (incidet) no pensamento de outra que, no entanto, não possui em si qualquer semelhança com a primeira (como o pensamento de um som articulado e o de um objeto, associados (jungere) apenas por sua afecção simultânea (simul) sobre um mesmo corpo humano, configurando uma conjunção per accidens); procede sem demonstração, encontrando amparo apenas na autoridade do testemunho.

\section{Conhecimento do segundo gênero ou Razão (Ratio).}

Obs.: É necessariamente verdadeiro; possui idéias adequadas; ensina a distinguir (distinguere) o bem do mal e o verdadeiro do falso; exclui toda possibilidade de dúvida: envolve a certeza (que não é uma ausência mas sim algo positivo, a saber, a presença do conhecimento da necessidade da verdade do conhecimento de seu objeto); possui, portanto, uma estrutura reflexiva; produz idéias que contêm, em si mesmas, mais realidade ou perfeição do que as idéias falsas; é de sua natureza contemplar as coisas como necessárias, sem nenhuma relação de tempo, sob a espécie da eternidade ( sub quâdam specie eternitatis), e não como contingentes. Além de tudo isso, comum a todo conhecimento adequado, é característico deste gênero ter por fundamento as noções comuns (notiones communes) ou idéias adequadas que percebem clara e distintamente as propriedades das coisas (ideas adcequatas proprietatum rerum), propriedades estas que estão igualmente na parte e no todo (aque in parte ac in toto) de qualquer corpo, afetante ou afetado, como condição da própria afecção; não explica a essência de coisa singular alguma (nullius rei singularis essentiam explicant); enquanto 
conhecimento verdadeiro do bem e do mal, dá origem às regras (regula) ou preceitos (pracepta) da razão, mas não pode, apenas por ser verdadeiro, refrear ou extinguir os afetos, dependendo, para tanto, daquilo que esse conhecimento seja, ele próprio, enquanto afeto; sua dimensão prescritiva (prascribit, postulat) nada contém que seja contra a natureza; ensina que algo se esforça (conatur) a se auto preservar e a procurar seu útil próprio; constitui o fundamento da virtude; trata-se de um conhecimento que a mente usa (utitur) a fim de inteligir e não a fim de outra coisa; ou seja, enquanto a mente raciocina (ratiocinatur), nada concebe de bom para si senão o que conduz (conducit) a inteligir (intelligere); é sob a condução da razão que os homens necessariamente convêm (conveniunt) em natureza e podem firmar uma sociedade civil (civitas)

\section{Conhecimento do terceiro gênero ou Ciência Intuitiva (Scientia Intuitiva)}

Obs.: Também aqui valem as características das idéias adequadas e, portanto, este terceiro gênero: é necessariamente verdadeiro; ensina a distinguir o verdadeiro do falso; envolve a certeza e exclui a dúvida; possui uma estrutura reflexiva; produz idéias que possuem, em si, mais realidade ou perfeição que as idéias falsas, etc. Mas, à diferença do que se passa no segundo gênero, o terceiro vai da idéia adequada da essência formal de certos atributos de Deus para o conhecimento adequado da essência das coisas (essência esta que também é algo real e atual); conhece as coisas como atuais, no sentido de estarem contidas em Deus e resultarem (consequi) da necessidade da natureza divina; coordena visão e conclusão (videmus, concludimus); segue a ordem do intelecto, pela qual a mente percebe as coisas por suas causas primeiras, e essa ordem é a mesma em todos os homens; concebe a essência do corpo do ponto de vista da eternidade; é capaz de fazer com que a mente sinta (sentit) aquilo que concebe intelectualmente, não menos do que são sentidas as imagens na memória; é capaz de certa visão: os olhos da mente (mentis oculi), com os quais vê e observa as coisas (quibus res videt observatque), são as demonstrações mesmas (ipsae demonstrationes); sua causa formal ou adequada é a mente, na medida em que (quatenus) esta é eterna; conduz ao cume da perfeição humana; origina o amor intelectual para com Deus, que em si mesmo é um amor eterno e que ocupa (ocupat) a mente acima de tudo, dando-lhe a maior satisfação possível, a satisfação do homem consigo mesmo (acquiescentia in se 
ipso), própria ao sábio (sapiens) e impossível ao ignorante (ignarus). As idéias que pertencem a esse terceiro gênero de conhecimento não podem derivar (sequi) das idéias mutiladas e confusas produzidas pelo primeiro gênero, mas podem derivar das idéias do segundo; a razão, contudo, é conhecimento universal (cognitio universalis), e o presente gênero, conhecimento das coisas singulares ou intuitivo (cognitio rerum singularium [sive] intuitivam).

Esse quadro contém, no sentido seiscentista do termo, uma pequena história ${ }^{304}$ da doutrina espinosana das maneiras de conhecer, ou pelo menos uma de suas partes mais importantes, qual seja, um inventário de características atribuídas por Espinosa a cada um desses processos. Apesar do inevitável trabalho interpretativo implicado nas tarefas de encontrar, traduzir, resumir e coordenar, essa collectio de predicados, além de ser bastante abrangente - embora não absolutamente exaustiva — , procura seguir de perto os textos de Espinosa. Sua principal finalidade aqui é permitir a visão de conjunto das semelhanças e diferenças que matizam a doutrina, bem como sua distribuição pelas três principais obras de Espinosa sobre o assunto, facultando a identificação dos pontos que serão cruzados pelas partes subseqüentes deste artigo.

Todas as obras, como acima se pode ver, apresentam restrições à razão ${ }^{305}$, o que parece bastante natural, dado que em todas também há um outro processo ulteriormente

${ }^{304}$ Em artigo dedicado à noção de história, explicitamente referida por Espinosa, na Carta 37, como noção proveniente do vocabulário de Bacon, procurei sintetizar seu sentido espinosano, presente também no Tratado da Emenda, nos seguintes termos: "A historia, por um lado, corresponde à circunscrição de um campo temático, à descrição dos dados ou elementos encontrados, não colocando ainda em questão se são verdadeiros ou falsos, ou se estão bem ou mal fundados: ela não se dá numa chave probatória ou demonstrativa. Não se trata ainda de demonstrar mas tão somente de mostrar certos elementos. Por outro lado, devemos também reconhecer que essa ordem exige que a descrição inicial dos conteúdos dados se faça sob a forma de um resumo completo - o qual, se não abarca tudo o que é logicamente concebível como pertinente ao conjunto, cobre, porém, tudo o que está disponível 'até o momento' (...). A ordem descritiva ou histórica não deixa de ser ordem, pois, embora as coisas que traz em primeiro lugar não tenham independência demonstrativa, ela ao menos impõe a razão da completude à multiplicidade que se apresenta nesse início e, por isso, pode inclusive reduzi-la a um número determinado (...). A ordem que naturalmente temos é aquela em que, para o conhecimento de algo desconhecido, o primeiro movimento é a realização de um inventário, isto é, um expediente que, na medida mesma em que encontra - invenit - uma multiplicidade dispersa e indiferenciada, busca encontrar alguma unidade, ainda que seja uma unidade de fato. E, como inventário, denominação e numeração, a história já é ordenação". Rezende, C.N. (2004), p. 106.

${ }^{305}$ Doravante, entenda-se por "razão" a segunda maneira do Breve Tratado, o terceiro modo do Tratado da Emenda e o segundo gênero da Ética. A fim de simplificar a forma de citação, abreviarei a referência a essas obras, respectivamente, com as seguintes siglas: KV (Korte Verhandeling), TIE (Tractatus de Intellectus Emendatione) e E (Ethica). Também usarei CM para os Cogitata Metaphysica. Todas estas obras possuem divisões internas que permitem a identificação suficientemente precisa dos trechos citados, sem necessidade de referência a qualquer edição em especial. Exceto quando indicado, todas as traduções das obras de Espinosa são de minha autoria, diretamente do texto latino editado por Gebhardt - Espinosa (1972). Ao citar o TIE, empregarei a numeração de parágrafos estabelecida por C. H. Bruder em 1843. A marcação das notas do TIE segue a seqüência de letras estabelecida por Rousset Espinosa (1992). 
apresentado como superior. Mas não faltou quem notasse que o texto do Tratado da Emenda do Intelecto se destaca por ser, ao mesmo tempo, aquele que "mais precisa de elucidação tanto quanto aquele que melhor elucida" ${ }^{306}$. Para além das diferenças de matiz, "a maior diferença de fundo costuma ser colocada no fato de que a Ética atribui à razão idéias adequadas, ao passo que o Tratado da Emenda qualifica esse modo de percepção como inadequado" ${ }^{307}$. Essa seria a principal ou talvez única variação a configurar, nesse núcleo temático, uma possível inconsistência, adicionando ao Tratado da Emenda - que já recebeu os anátemas de mal escrito, obscuro, juvenil, paradoxal ${ }^{308}$, cartesiano e intrinsecamente fadado ao inacabamento ${ }^{309}$ - mais uma aberração frente ao que se deveria considerar como o espinosismo castiço contido na Ética. Entretanto, creio que essa tradicional dificuldade para integrar o Tratado da Emenda ao conjunto do pensamento de Espinosa seja um sintoma privilegiado para investigar, antes, a imagem do espinosismo que preside tal sentimento de incompatibilidade. De fato, quando se espera que, mais cedo ou mais tarde, a idéia principal de Espinosa se confesse como "no fundo, o mesmo que o to ov dos eleatas" 310 , isto é, como "unidade abstrata" que funda uma filosofia hostil ao movimento, à particularidade e à determinação na ordem da ontologia e unilateral, rígida e abstrata na ordem do conhecimento, em suma, filosofia restrita ao entendimento, não especulativa e distante da concretude, faz-se compreensível que o Tratado, ao valorizar o entendimento (intellectus) e sua ciência intuitiva justamente como conhecimento da particularidade concreta, e ao criticar a razão justamente por poder ficar pela esfera de um conhecimento abstrato e inadequado, revele-se dificilmente compatível com um tal "espinosismo".

Na tentativa de defender o Tratado da Emenda, é possível alegar, como já se fez $^{311}$, a ocorrência de uma equivocidade e afirmar que, no que toca a inadequação da razão, esse termo não possuiria no Tratado o mesmo sentido que veio a ter na Ética. Mas isso exige que se defina muito bem o sentido em que Espinosa usa as qualificações adequado/inadequado na exposição que o Tratado faz da doutrina das maneiras de conhecer. Eis, pois, o que pretendo fazer. Mas não só. Pretendo também demonstrar que, embora haja sim um uso especial da noção de inadequação no Tratado, esse uso

306 Matheron (1986) p.125.

307 Spinoza (1990) p. 234, nota 123.

308 Como bem nota Moysés Floriano (2002), isso se deve, em boa parte, à supervalorização da advertência ao leitor (Admonitio ad lectorem), adicionada pelos editores da Opera Posthuma.

${ }^{309}$ Matheron (1987)

${ }^{310}$ Hegel (2002) p. 248.

${ }^{311}$ Spinoza (1990 p. 234, nota 123. 
não trai o núcleo básico que o termo possui na Ética, sem que haja inconsistência mas também sem que se omita a relevância filosófica dessa variação, relevância esta que fornece alguns subsídios para repensar a imagem histórica do espinosismo.

\section{2) Razão e conhecimento de propriedades}

Dentre as características que, no Tratado da Emenda, exprimem a inadequação das conclusões racionais, eu gostaria de selecionar aquelas que concernem à limitação desse processo ao conhecimento de propriedades (propria). Acerca desta última noção, convém fazer dois comentários: o primeiro, partindo de um indício de natureza filológica, enquanto tal, apenas sugere uma hipótese, ao passo que o segundo, de natureza conceitual, a comprova.

Com efeito, o uso da forma propria, no neutro plural, é infreqüente em Espinosa, que prefere proprietas, proprietatis, para falar de propriedades. A hipótese que isso sugere é que Espinosa, ao empregar "propria", teria presente em sua memória, ou desejaria evocar, mais precisamente do que em outros contextos, o conceito

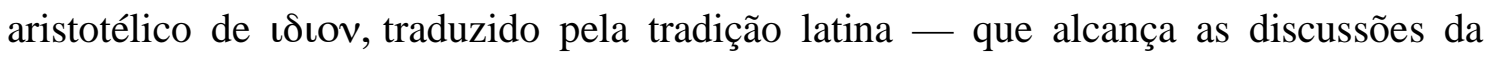
escolástica barroca sobre lógica — justamente como proprium. Tal conceito é definido por Aristóteles nos seguintes termos:

"É próprio aquilo que, embora não mostre o quê era ser, se atribui a uma coisa apenas e se contra-predica reciprocamente dela. Por exemplo, é próprio do homem ser capaz de saber ler e escrever; pois se algo é homem, é capaz de ler e escrever, assim como, se algo é capaz de saber ler e escrever, é homem. Pois ninguém afirma ser próprio aquilo que pode ser atribuído a outro (por exemplo, o dormir em relação ao homem), nem se ocorre ser atribuído a um único item apenas segundo um certo tempo. Pois se também algum dos itens desse tipo fosse denominado como próprio, não seria denominado simplesmente sem mais, mas antes próprio em certo momento ou em relação a algo. Pois estar do lado direito é próprio em algum momento, ao passo que bípede sucede ser dito como próprio em comparação com algo, por exemplo, para o homem, em comparação com o cavalo e o cão"

Os propria são aspectos não essenciais de algo, mas que lhe são coextensivos, ou

${ }^{312}$ Aristóteles, Tópicos I,5 102 18 in Angioni,L. (2000), p.49 
ainda mais, que podem ser "contra-predicados" desse algo. Como nota Lucas Angioni ${ }^{313}$ a respeito da noção aristotélica de propria, o critério para a determinação dessa propriedade é tão estrito que ela não se confunde, por exemplo, com o chamado "atributo per se", o qual implica a espécie da coisa de que é predicado mas não é por ela implicado, ou seja, não é contra-predicável: se algo é "par", então trata-se de um número, pois o "par" só se diz de números e é, dessarte, um atributo per se de número; mas não se segue, conversamente, que, se algo é número, então é necessariamente par.

Também na chamada Lógica de Port-Royal — publicada pela primeira vez em 1662 e parte do universo intelectual freqüentado por Espinosa - reaparece uma definição equivalente do proprium, agora, porém, acompanhada de um exemplo que surge nos mesmos termos no Tratado da Emenda, o que encaminhará a passagem da hipótese aqui em pauta para sua confirmação:

"quod convenit omni, soli \& semper; como é o próprio de todo círculo, e do círculo somente, e sempre, que as linhas tiradas do centro à circunferência sejam iguais",314.

Em seu sentido principal e primeiro, o proprium é, na exposição seiscentista como na de Aristóteles, um tipo de predicado que, embora não determine a diferença que constitui uma espécie, ou seja, o atributo essencial que a distingue de todas as demais, está necessariamente ligado, por uma relação de dependência, à diferença e, portanto, sempre convém a tudo que é abarcado sob essa espécie e somente a isso.

Ora, no parágrafo 95 do Tratado da Emenda, a teoria espinosana da definição se manifesta nos seguintes termos:

"A definição, para que seja dita perfeita, deve explicar a essência íntima da coisa, e cuidar (cavere) para que em seu lugar não usemos (usurpemus) próprios (propria); para explicar isso, omitirei outros exemplos a fim de que não pareça querer denunciar os erros dos outros, e referir-me-ei apenas ao exemplo de alguma coisa abstrata, que é a mesma qualquer que seja o modo como é definida, a saber, o exemplo do círculo: se definido como sendo uma figura cujas linhas tiradas (ductce) do centro à circunferência são iguais, ninguém deixará de ver que essa definição, de maneira alguma (minime), explica a essência do círculo, mas apenas uma

313 Angioni, L (2000), p. 145

${ }^{314}$ Arnauld, A. \& Nicole, P. (1965) p. 63. Mantive em latim a primeira parte do trecho, tal como está no original, que não traduz essa parte para o francês. Sua tradução é: "o que convém a tudo, só a isso e sempre". 
propriedade (proprietatem), ${ }^{, 315}$

Insistindo no fato de que, em se tratando de entes de razão (entia rationis) como o círculo, é indiferente o processo definitório, Espinosa mostra como essa maneira de definir é altamente nociva quando se trata de entes físicos e reais (entia physica et realia), uma vez que por ela pervertemos (pervertimus) a concatenação da natureza (natura concatenationem), porquanto as propriedades, que então deveriam estar na definição da coisa, não podem ser entendidas enquanto a essência for ignorada. Com efeito, se o conhecimento das propriedades depende do conhecimento da essência da coisa, é claro que o conhecimento desta última não pode ficar na dependência do conhecimento das primeiras sob pena de circularidade lógica (que estimo ser o sentido da perversão supra referida).

O Tratado de Espinosa prossegue, pois, com as condições de uma definição perfeita, apresentando, logo de início, a emenda do erro contido naquela primeira:

"se a coisa é criada, a definição deverá, como dissemos, compreender a causa próxima. Por exemplo, o círculo, segundo esta lei (hanc legem) deve ser definido assim: é uma figura descrita (describitur) por uma linha qualquer, da qual uma extremidade é fixa e a outra é móvel, definição esta que claramente compreende a causa próxima",316

Ora, o cruzamento da doutrina das maneiras de conhecer com a doutrina da definição — aliás, previsto já pela caracterização do quarto modo de perceber como dedutivo a partir de uma verdadeira e legítima definição - confirma a hipótese levantada: o caráter estrito dos propria aristotélicos corresponde perfeitamente à certeza alcançada ao nível da razão, isto é, àquela peculiar noção de certeza não suficientemente segura. Porque, se algo tem todos os pontos eqüidistantes do centro, então é um círculo,

315 TIE $\S 95$ : "Definitio ut dicatur perfecta, debebit intimam essentiam rei explicare, et cavere, ne eius loco propria quadam usurpemus. Ad quod explicandum, ut alia exempla omittam, ne videar aliorum errores velle detegere, adferam tantum exemplum alicuius rei abstracto, qua perinde est, quomodocumque definiatur, circuli scilicet; quod si definiatur, esse figuram aliquam, cuius linea, a centro ad circumferentiam ducte, sunt aquales, nemo non videt talem definitionem minime explicare essentiam circuli, sed tantum eius aliquam proprietatem." - É de notar que, num mesmo parágrafo, Espinosa oscila entre propria e proprietates, reforçando a limitação do enfoque filológico ao campo dos indícios. Estes, porém, não perdem aqui sua força sugestiva, porque o importante não é que proprietas também seja usado, mas que propria quase nunca seja, dando peculiar relevo ao contexto em que comparece, quando comparece.

316 TIE § 96: "Si res sit creata, definitio debebit, uti diximus, comprehendere causam proximam. Ex. gr. circulus secundum hanc legem sic esset definiendus: eum esse figuram, qua describitur a linea quacunque, cuius alia extremitas est fixa, alia mobilis, qua definitio clare comprehendit causam proximam" 
e se é um círculo, tem todos os pontos eqüidistantes do centro. Mas com isso sabe-se, por assim dizer, o que o círculo necessariamente tem e não o que ele é: ele é conhecido abstratamente, apenas como um oculto 'proprietário' da propriedade e não em sua essência íntima. O mesmo se confirma através dos exemplos dados por Espinosa no próprio contexto de apresentação do terceiro modo de perceber. Tome-se o seguinte exemplo, concernente à inferência racional da causa a partir do efeito:

"depois que claramente percebemos que sentimos um tal corpo e nenhum outro, daí (inde), afirmo, claramente concluímos estar a alma (animam) unida ao corpo, o que é a causa dessa sensação; mas o que seja essa sensação e essa união, não podemos inteligir daí (inde) absolutamente.”317

Ou seja, se sentimos nosso corpo e não outro, deve haver — recordem-se os termos do Breve Tratado (behoort zyn, moet zyn) - uma união entre a alma e o corpo, e reciprocamente, se há uma tal união, sentimos nosso corpo e não outro. A sensação, tomada como efeito exclusivo da união entre a alma e o corpo, opera como um proprium que acusa certeiramente essa união, muito embora não a torne conhecida (e se alguém a conhece, não é a partir daí sem mais, isto é, absolutamente). A eficácia da operação racional que trabalha com os propria é total, mas - correspondendo à insuficiência que condiciona o impedimento de outra espécie de erros a um máximo cuidado adicional (nisi maxime caventibus) - essa sorte de propriedade, bem como sua contra-predicabilidade, não constituem, nem mesmo para Aristóteles, uma base que permita absolutamente entender a essência da coisa. Como esclarece Angioni, é certo que Aristóteles concebe a definição como uma "estrita asserção de identidade", de maneira que o termo definido seja substituível pelo enunciado definidor (e vice-versa) "em qualquer contexto, preservando-se o valor de verdade da sentença em que inicialmente o termo definido ocorrera"; todavia,

"esse critério é apenas condição necessária, mas não suficiente, para a estrita adequação científica da definição (...) A definição, em sua versão estritamente científica, como princípio das demonstrações, deve - pelo menos de direito - captar a estrutura constitutiva da coisa definida, de modo a fornecer uma razão suficiente para a dedução de seus atributos necessários" 318

317 TIE § 21: "postquam clare percipimus, nos tale corpus sentire et nullum aliud, inde, inquam, clare concludimus animam unitam esse corpori, qua unio est causa talis sensationis 1); sed quanam sit illa sensatio et unio, non absolute inde possumus intelligere."

${ }^{318}$ Angioni (2000) p. 144 
Para que não se pense que isso significaria "aristotelizar" Espinosa, é prudente ressaltar que, a despeito do notável acordo entre os dois filósofos quanto ao sentido geral dos requisitos de uma definição perfeita, há grande diferença quanto ao modo pelo qual cada um considera que tais requisitos podem ser atendidos. No caso de Espinosa, há um papel importantíssimo a ser desempenhado pelo conhecimento da causa eficiente, ao passo que, para o Estagirita, essa causa parece ser externa à unidade complexa entre matéria e forma que a definição, de certa maneira, reproduz num nível lógico. Para ambos, algo deve ser definido de tal forma que o conceito não só permita o êxito na sua identificação através de propriedades ou efeitos exclusivos, mas sobretudo explicite a essência da coisa, ou seja, forneça uma compreensão que, sozinha, baste para compreender os efeitos e concluir todas as propriedades do definiendum. Mas — com desejável jogo de palavras - o próprio da perspectiva espinosana é que a definição perfeita não possa ser outra senão aquela que, de alguma maneira, narra a coisa de forma causal, isso significando, no exemplo paradigmático do círculo, empregar o movimento, ou seja, a causa eficiente.

Ao dizer que o terceiro modo de perceber não apreende a essência particular da coisa mas apenas propria, Espinosa está, portanto, empregando um conceito tradicional da filosofia de inspiração aristotélica e fornecendo uma sinalização de como a crítica à inadequação desse modo de perceber deve ser articulada à crítica da definição pela propriedade. Diferentemente de uma descrição ostensiva (pictórica?) de propriedades, a apresentação do esquema construtivo do círculo, porque permite construir um círculo, permite, ipso facto, a obtenção de todas as propriedades que um círculo necessariamente possui. Quando realizada construtiva ou geneticamente, a captação da estrutura constitutiva da coisa, envolvendo a causa eficiente, não apenas fornece a razão suficiente para a dedução de suas propriedades necessárias, como fornece também o princípio de unificação dessas propriedades entre si, e portanto, o detalhamento de como se estabelece essa sua necessidade: quando o círculo é definido como a figura descrita por uma linha qualquer, da qual uma extremidade é fixa e a outra é móvel, não cabe perguntar se ou por que ou como a figura assim produzida tem todas as retas, tiradas do centro à circunferência, de igual medida. Da mesma forma, diante do incriado, quando este é definido como aquilo cuja essência envolve a existência, ou seja, aquilo cuja natureza não pode ser concebida senão como existente, “non manet locus Qucestioni ‘An 
sit", 319

Se é assim, a lei de formação de definições se afigura, em seus requisitos mínimos, como a mesma para as coisas criadas e incriadas. Convém responder, brevemente, por que, então, Espinosa afirma no Tratado da Emenda que a definição do incriado deve excluir toda causa, ao passo que o traço mais marcante da definição das coisas criadas é a apresentação de sua causa próxima. Ora, averiguada a caracterização do quarto e mais perfeito modo de percepção proposto nesse Tratado, apresenta-se prontamente a alternativa: "percepção em que a coisa é percebida por sua só essência, ou por sua causa próxima" ${ }^{, 320}$. A complementaridade e a fina distinção entre essência e causa se verifica em muitas passagens do pensamento espinosano e mantém-se constante ao longo da obra, como é constatável, por exemplo, através do exame das definições de possível e contingente nos Cogitata Metaphysica e na Ética ${ }^{321}$. Mas, julgo que a radical exclusão, afirmada no Tratado da Emenda, de toda causa na definição do incriado é, no mínimo, algo a ser comentado, sobretudo quando está no horizonte a causalidade eficiente imanente proposta na Ética - onde também se propõe que Deus é causa de si no mesmo sentido em que é causa do mundo.

Sem alterar a perspectiva desta análise, dedicada à razão no Tratado $d a$ Emenda, com seu precoce redirecionamento para o conceito de causalidade eficiente imanente na Ética, basta aqui reconhecer que o requisito mínimo de uma verdadeira e legítima definição é que ela forneça as propriedades ao fornecer a compreensão das condições suficientes de existência do definiendum. Nisto não há qualquer diferença entre a definição do criado e do incriado: ambas articulam internamente as condições suficientes de existência da coisa definida e a derivação das suas propriedades. Quer tais condições suficientes de existência remetam a causas eficientes externas, quer remetam à só essência da coisa, elas hão de constituir o significado de uma definição que se pretenda genética ou construtiva.

Aliás, nesse sentido, a definição da causa sui ${ }^{322}$ — a primeira de todas na Ética proxima causa"

${ }^{319}$ TIE § 97: "não permanece lugar para a questão 'Se é"”

${ }^{320}$ TIE § 19: "perceptio (...) ubi res percipitur per solam suam essentiam, vel per cognitionem suce

${ }^{321}$ Nos CM III, 8, Espinosa afirma que possível é a coisa cuja causa eficiente é conhecida, mas ignoramos se é determinada, ao passo que contingente é a coisa que, tomada sem sua causa, ou seja, somente em sua essência, não implica existência necessária nem impossibilidade para existir. Os dois conceitos reenviam, pois, a uma limitação de nosso conhecimento, coisa alguma sendo, dessarte, contingente ou possível em si mesma. Em E I, prop 33, escólio 1, Espinosa também argumenta na mesma direção, retomando essa idéia de que a existência das coisas ou é determinada por sua própria essência (como no caso de Deus) ou por sua causa (que então é inserida naquela trama infinita de causas congêneres, aí chamada de ordem das causas).

322 "Per causam sui intelligo id cujus essentia involvit existentiam sive id cujus natura non potest 
— surge como paradigmática do que seja uma verdadeira e legítima definição genética: a concepção da natureza da coisa já é, de alguma forma, o conhecimento de que ela existe como algo presente e real. Essa maneira de principiar, performativamente vinculada à doutrina espinosana da definição, nada tem de um mistificador "começo", abstrato no sentido de que se posicionaria como se dele não houvesse construção ou gênese. Bem ao contrário, a primeira definição da Ética não se diferenciaria, por exemplo, de uma definição escolástica de Deus — "Aliquid enim est, sicut Deus, cuius essentia est ipsummet suum esse" ${ }^{, 323}$ — se essa identidade entre essência e existência não estivesse sendo subsumida à rubrica da causalidade, como causa de si. Se é verdade que o Tratado da Emenda fala da definição da coisa increata em termos negativos, ou seja, afirma uma exclusão de toda causa $^{324}$, considero que, ao invés de uma doutrina juvenil, que ainda não teria levado o princípio de causalidade à afirmação radical e positiva que encontra na Ética, essa maneira de falar seja decorrente da perspectiva própria ao Tratado. De acordo com ela, seguindo a ordem que o homem naturalmente tem, as coisas finitas são tomadas como ponto de partida (embora jamais como fundamento $)^{325}$, e por isso, o Tratado não se furta ao diálogo com a imaginação e à inspeção interna do discurso vulgar:

"se a coisa é em si, ou seja, como diz o vulgo, causa de si, então deve ser

concipi nisi existens. / Por causa de si entendo isso cuja essência envolve a existência, ou seja, isso cuja natureza não pode ser concebida senão existente". É de notar o emprego, como última palavra da frase, do particípio presente existens. Isso constitui um dado filológico complementar, que reforça as idéias de presença e realidade, ou caso se prefira, de atualidade e concretude

323 "Há algo como Deus, cuja essência é seu próprio ser", como diz Tomás de Aquino, ao comentar o tríplice modo pelo qual algo tem essência, no De Ente et Essentia, V, 1 [Aquino, (1996), p. 106].

${ }^{324}$ TIE § 97: "Definitionis vero rei increatce hac sunt requisita: Ut omnem causam secludat, hoc est, obiectum nullo alio prater suum esse, egeat ad sui explicationem / Mas quanto à definição da coisa incriada, estes são os requisitos: Que exclua toda causa, isto é, que o objeto nada exija além de seu ser para sua explicação."

325 "É certo que, por um lado, estamos muito longe de uma "história do pormenor, do acidente, da continuidade linear" (...) isto é, de uma história que se subordine imediatamente à finitude; mas, por outro lado, não se pode dizer que a finitude esteja absolutamente separada (...). O conhecimento proporcionado pelo método histórico mergulha, é certo, no elemento da duração, isto é, no espaço e no tempo (...) ele adentra na duração para, ao conhecê-la como tal, nela operar uma profunda alteração da ordem (...) a fim de verificar segundo quais leis das coisas eternas cada coisa singular acontece e até mesmo, por exemplo, como a imaginação acontece (...). Dessarte, se nos for lícito retomar agora o conceito de verdadeiro sentido, que encontramos no contexto de elaboração da história das Escrituras, poderíamos propor que entendêssemos o conhecimento verdadeiro não como sendo o conhecimento da ilusão a que seriam redutíveis os entes singulares finitos, mas sim, como sendo o conhecimento de seu verdadeiro sentido, isto é, na linguagem de Ética, como sendo a compreensão de que cada coisa exprime Deus ou a natureza justamente porque o faz de maneira precisa e determinada — e não a despeito disso —, e que, em contrapartida, está na própria essência de Deus que, dela, deve decorrer uma infinidade de coisas que, efetivamente, hão de existir sob a forma de uma infinidade de modos". Rezende, C.N. (1997) pp. 119120. 
entendida só por sua essência, e se, ao contrário, a coisa não é em si, mas requer uma causa para existir, então deve ser entendida através de sua causa próxima" 326 .

Ora, como se verifica no quadro sinóptico introdutório, a imaginação trabalha com um discurso onde o positivo é indicado negativa e indiretamente, fazendo com que o conhecimento do que em si é anterior e incondicionado surja como derivado do que é posterior e condicionado ${ }^{327}$. Ela procede por dupla negação, contraditoriamente derivando, por exemplo, o infinito por negação do finito (o qual já era, porém, a negação de algo e, como tal, algo 'segundo'). Esse 'infinito por negação' — um mal infinito - se faz, assim, congenitamente limitado ou 'findado' pelo finito, frente ao qual permanece essencialmente - isto é, por definição — separado e desarticulado. Mas o diálogo emendador do Tratado com a imaginação não pode, sob a mesma pena, incorrer numa negação da duplex negatio. Ele não realiza uma simples oposição unilateral frente à imaginação, fechando-se contra ela exatamente como ela tende a fechar-se sobre si mesma. Ao contrário, ele revela sua vocação de, sem deplorar ou ridicularizar, compreender a imaginação, penetrando em sua perspectiva e, a partir desse interior, realizando uma gradual - e sobretudo contínua - torção no sentido dos conceitos. O Tratado se permite, pois, no diálogo com a imaginação, falar do increatum por oposição ao "criado", falar por oposição às circunstâncias infinitas que condicionam a gênese das coisas particulares mutáveis ${ }^{328}$. E, nessa perspectiva, realmente faz sentido dizer que o que é em si deve excluir toda causa, ou seja, toda dependência de uma causa próxima. É mais pelo seu modo compreensivo de argumentar do que pelo vocabulário empregado, que o Tratado sugere a passagem da causa sui negativa (que torna misteriosa a causação do mundo finito e seu nexo com a causa primeira) à causa sui positiva, que é causa do mundo ao ser causa de si, assim como o intelecto, ao invés de simplesmente negar a imaginação, a discerne e compreende ao compreender a si mesmo.

Esses comentários são aqui oportunos na medida em que auxiliam a compreensão do que se deva entender por 'definição genética ou construtiva': não se trata, no caso do criado, de reconstituir a série infinita de causas pela qual um modo

${ }^{326}$ TIE $\S 92:$ "si res sit in se, sive, ut vulgo dicitur, causa sui, tum per solam suam essentiam debebit intelligi; si vero res non sit in se, sed requirat causam ut existat, tum per proximam suam causam debet intelligi $"$. Itálicos meus na tradução.

${ }^{327}$ Cf. TIE § 89

${ }^{328}$ Cf. TIE $§ 99-100$ 
finito foi produzido (uma tarefa inexequiível para o homem), nem tampouco, no caso do incriado, de narrar como, por si mesmo, ele passou da inexistência à existência (o que é uma contradição, mero absurdo); trata-se, ao contrário, da construção da idéia que dá a conhecer as articulações internas de todas as condições necessárias da existência da coisa. O conhecimento da totalidade das condições necessárias articuladas equivale ao conhecimento da condição suficiente da coisa, enquanto a montagem da idéia baseada em um fazer e não em um descrever - fornece o conhecimento dessas articulações entre as propriedades, isto é, de seu 'entrelaçamento'.

Esse é o cerne de uma definição que, versando sobre o criado ou sobre o incriado, seja algo mais do que mero elenco de propriedades identificatórias, justapostas entre si e - malgrado seu caráter necessário - apenas superpostas àquilo a que são atribuídas. Numa definição genética, as propriedades não mais figuraram como um polissíndeto de predicados que circunscrevem, de maneira lacunar, o espaço reservado ao sujeito focal de sua atribuição: figuram, antes, como uma unidade complexa que não poderá existir realmente sem que, ipso facto, exista realmente o ente que as possui pois que essa unidade é a constituição dele —, tanto quanto ele não pode existir sem elas. Do mesmo modo, as propriedades não podem ser assim concebidas sem que sua concepção como uma unidade já não seja o próprio ter a idéia verdadeira da coisa, e vice-versa. E essa idéia há de ser, pois, não somente clara, por manifestar a identidade, unidade ou consistência intrínseca de seu conteúdo, como também distinta, por revelar a forma de entrelaçamento da multiplicidade de propriedades constitutivas dessa identidade complexa.

\section{3) Razão: "embora certa, não suficientemente segura”}

Agora, a fim perscrutar aquele que chamei de núcleo básico da inadequação da razão, convém analisar alguns pormenores dos textos em que o assunto comparece no Tratado da Emenda, sobretudo no conjunto de parágrafos de 19 a 29, acompanhado de algumas de suas notas (nomeadamente as notas $f, g$ e $h$ ), adentrando por fim no exemplo matemático dado por Espinosa para unificar a compreensão dos diferentes modos de perceber, e atentando ao papel que nesse exemplo desempenha a referência aos Elementos de Euclides.

Segundo esses textos, a referida inadequação do terceiro modo ocorre em dois casos: quando dos efeitos procura-se coligir a causa, e quando a essência é concluída de um universal acompanhado de propriedades sempre concomitantes. É sobretudo esse 
segundo caso que parece estar em pauta no contexto da definição perfeita, mas, como já foi dito, em ambos os casos a inadequação é proveniente de uma insuficiência intrínseca que faz com que a certeza estabelecida só deixe de envolver algum risco ou perigo mediante outra condição ("nisi”) — um cuidado máximo — que deve ser adicionada. Embora, por exemplo, Matheron ${ }^{329}$ considere que o segundo caso é mais abrangente e que abarca o primeiro - com o que tendo a concordar, visto que vinculo a questão sobretudo à doutrina da definição — julgo que o que há de mais abrangente é uma configuração básica comum, que se repete nos dois casos: há sempre dois termos, um do qual se parte (ex/ab A) e outro ao qual se chega (concluditur/colligimus B), e sempre este último, embora seja eficazmente identificado, não é sabido em sua “intimidade", em sua "particularidade". No registro causal, nada da causa é entendido senão o que já fora considerado nos efeitos, e no registro lógico, nada é conhecido da essência particular do definiendum senão as mesmas propriedades que foram propostas como definientes: assim como, além do círculo, não há outra figura que possa ser admitida como detentora da propriedade de ter todos os seus pontos eqüidistantes do centro, assim também, nada além da união da alma e do corpo pode ser suposto como causa da sensação; mas, em ambos os casos, não se entende o que seja um círculo ou o que seja essa união e, conseqüentemente, a coisa e a causa são assumidas, respectivamente, como um mero aliquid e como aliqua potentia.

Sabe-se, inequivocamente, que o termo de chegada (B) não pode ser outro, mas isso corresponde a uma definição diferencial ou negativa: tal propriedade não pode ser possuída pelo quadrado, nem pelo triângulo, etc. Por isso Espinosa diz que a inadequação aparece tanto no fato do termo obtido ser explicado por noções generalíssimas, quanto no fato de que ele é expresso negativamente: "ergo non est hoc, vel illud, etc ${ }^{\text {} 330}$. Aliás, seria possível prolongar essas considerações e entender que, por esse modo de perceber, a própria realidade última, a substância, então suposta pelo princípio de que "do nada, nada se faz" e de que "o nada não tem propriedades", ficaria assumida, generalissimamente, como o suporte da propriedade de ter propriedades e/ou efeitos, sendo, então, duplamente marcada pela negatividade: $o$ não-nada. Talvez devase encontrar aqui uma das bases para a recusa espinosana da noção de substância como mero sujeito lógico ou substrato físico de atribuição ou inerência de propriedades, e da noção de atributo que se degenera nesse proprium da substância. Mas discutir isso

\footnotetext{
329 Matheron (1986) p.125

${ }^{330}$ TIE $\S 19$, nota $f$ : "logo não é isso, mas aquilo"
} 
avançaria muito além do escopo do presente artigo.

O que cumpre ainda notar é que a nota $g$, no parágrafo 21 - ratificando a conformidade do exemplo da união da alma e do corpo às restrições apresentadas à conclusão que se vale dos propria (nota $f, \S 19$ ) — também afirma que, por esse modo de perceber, só se entende $\mathrm{A}$, o termo que é atribuído àquele que comparece como seu suporte, B, o qual permanece desconhecido em sua essência, apesar de haver sido identificado ou indicado. Mas o mesmo parágrafo 21 radicaliza a crítica: nem a união da alma e do corpo (B), suposta como causa da sensação, é entendida, nem tampouco a própria sensação (A), porquanto esta noção, de certa forma, suplanta aquela pela qual deveria ser explicada, e perdura, assim, carecendo de um fundamento melhor do que um mero "algo" suposto, uma "união" que não vale mais do que uma "virtude sensitiva" ou abstrações que tais. A inadequação da obtenção do segundo termo é o fracasso na busca da condição de entendimento do primeiro, reconfigurando aquela perversão circular na concatenação interna da narrativa mental que deveria reproduzir a ordem da natureza.

A nota $h$, também do parágrafo 21 , deixa explícito que, por si só, a eficácia da identificação de um suporte para a propriedade, de uma causa suposta para o efeito, é a imediata incidência em erros ("statim in errore incident"), caso não se adicione um cuidado a mais. Esse modo de percepção toma os dois termos (A e B) como externamente relacionados, põe como múltiplo o que é uno - a causa e o efeito, a essência e a propriedade - e, depois dessa separação, qualquer reunião ulterior só pode mesmo ser percebida como justaposição ou superposição, enfim, como confusão.

Com o exame do exemplo do $4^{\circ}$ número proporcional, vê-se que essas mesmas características do terceiro modo aí perduram e figuram de modo claríssimo: assim como não há, entre as figuras geométricas, outra além do círculo que detenha todos os pontos eqüidistantes do centro, assim também, proposta a série 2,4,3,X, não há outro número além de 6 que possa ser admitido como detentor da propriedade de ter o produto de sua multiplicação pelo $1^{\circ}$ número, igual ao produto da multiplicação do $3^{\circ}$ pelo $2^{\circ}$. Mas, nem por isso, faz-se sabida a adequada proporção entre os números dados, ou seja, no caso, a razão de dobro.

Diante de números em que a ratio não é tão evidente ${ }^{331}$, é perfeitamente possível

${ }^{331}$ Sigo, com essa decisão de empregar números 'grandes', o mesmo recurso usado por Matheron (1986). Mas, creio que a maior importância desse recurso é contestar que todos os modos de perceber só poderiam ser ilustrados conjuntamente por um exemplo montado com números muito simples. Como será demonstrado logo a seguir, deve haver um modo de perceber intuitivamente a proporção entre os números 'grandes' aqui escolhidos e que não se diferencia daquele modo pelo qual é percebida intuitivamente a proporção 
proceder dessa maneira e, fazendo como os matemáticos, pela força da proposição 19 do Livro VII dos Elementos de Euclides ${ }^{332}$ - ou seja mediante o proprium de todo grupo de números que se subsume à definição dos números proporcionais ${ }^{333}$ - calcular, por exemplo, qual deve ser o número que está para 119 assim como 195 está para 85 . No seguinte esquema, $85 \rightarrow 195=119 \rightarrow \mathrm{X}$, (onde " $\rightarrow$ " deve ser lido como "está para"), basta resolver a equação $85 \mathrm{X}=195 * 119$ para chegar ao valor de 273 . É inquestionavelmente certo que esse é o valor que torna os quatro números proporcionais; e o termo "certo" pode, nesse caso, significar até mesmo que o resultado está correto e que sempre estará correto quando se parte daquela propriedade numa situação que deve estar subsumida à natureza geral das proporções. Mas, embora fique certo que esse é o resultado e que os quatro números são, de fato, proporcionais, não se sabe o que ou qual é a proporção e muito menos por que ela é tal, visto que não se sabe qual seja ela, mas apenas o número que a estabelece. Afora a natureza geral de toda proporção, ignora-se, no caso concreto, o conteúdo particular do símbolo “ $\rightarrow$ ”, que é o elemento comum entre as duas expressões e o promotor da igualdade expressa como equação. A expressão simbólica " $85 \rightarrow 195=119 \rightarrow X$ " é particularmente ilustrativa porque deixa claro que não há uma única mas sim duas lacunas a serem preenchidas por um conteúdo fixo e determinado: a lacuna " $\rightarrow$ " e a lacuna "X". O terceiro modo de

entre 2 e 4 e entre 3 e 6 . Aliás, se há um modo de perceber para o qual faz diferença a simplicidade ou a complexidade dos números, esse modo não é a intuição mas sim a imaginação, à qual é próprio perder a distinção quando as quantidades ultrapassam certo limiar. No Tratado da Emenda, é afirmado ser a experiência o modo que, no cálculo de qualquer quarto número proporcional, grande ou pequeno, procede pela generalização de uma regra originada de casos simples "onde o quarto número é patente por si, como nesses [números] 2, 4, 3, 6". Assim, todos os modos de perceber podem ser exemplificados por qualquer quarteto de números proporcionais, mas a escolha de números 'grandes' facilita a pontuação de cada uma das etapas internas que diferenciam um modo do outro. Ademais, uma vez que o que há de próprio no terceiro modo é a obtenção do resultado e a ignorância da proporção, o uso de números 'grandes' faz-se particularmente pedagógico, pois suscita no leitor a percepção que o filósofo descreve, assim como um exemplo com números baixos suscita melhor a percepção da qual se origina o modo da experiência vaga. Se Espinosa escolheu números 'pequenos', julgo que assim o fez em razão do privilégio que a experiência possui no Tratado, pois que trata-se aí de dialogar com esse modo de percepção e penetrar em seu interior para transformá-lo de dentro para fora. A escolha de números baixos também na Ética não desmente esta interpretação, pois, como se demonstra mais adiante, o quarteto escolhido em tal obra também exprime a peculiaridade de seu registro de discurso. Em todo caso, o que almejo evidenciar com a escolha de números altos é a peculiaridade, não dos primeiros nem do quarto modo de perceber, mas sim do terceiro e, para tanto, julgo que tal escolha é apropriada como espero que o restante deste artigo confirme por si mesmo.

332 "se quatro números são proporcionais, o número produzido do primeiro e do quarto será igual ao número produzido do segundo e do terceiro; e se o número produzido do primeiro e do quarto for igual ao produzido do segundo e do terceiro, os quatro números são proporcionais" - Tradução minha a partir da trad. inglesa de Heath [Euclides (1952), Livro VII, prop 19]. É de notar que o enunciado dessa proposição caracteriza a propriedade em questão pela meta-propriedade da contrapredicabilidade, isto é, pela propriedade que qualifica apenas as propriedades que são $\iota \_\_$, ou seja, propria.

333 "Números são proporcionais quando o primeiro é o mesmo múltiplo, ou a mesma parte, ou as mesmas partes do segundo, que o terceiro é do quarto". Tradução minha a partir da trad. inglesa de Heath em Euclides (1952), Livro VII, Def. 20. 
perceber permite o preenchimento da segunda sem que tenha sido feito o preenchimento da primeira, a qual, no entanto, pela própria configuração da expressão simbólica, é claramente a lacuna antecedente que condicionaria o preenchimento da segunda. Por meio desse terceiro modo, faz-se possível manipular a primeira lacuna sem preenchê-la e, ainda assim, determinar o conteúdo da segunda. Analogamente ao "aliquid" e à "aliqua potentia" que comentavam os exemplos particulares do terceiro modo, pode-se dizer, agora a propósito do exemplo matemático comum, que o " $\rightarrow$ ” perdura, no procedimento dos matemáticos, apenas como aliqua proportio.

A propriedade dos números proporcionais, digamos $R$ (segundo a qual o produto dos meios é igual ao produto dos extremos), permite que se identifique o resultado sem que, no entanto, seja sabido o mais importante, isto é, que 85 contém dezessete vezes em si aquilo que 195 contém trinta e nove (a saber, cinco unidades), assim como 119 contem dezessete vezes em si, aquilo que 273 contém trinta e nove (a saber, sete unidades). Se a natureza geral da proporção, apresentada na Definição 20 dos Elementos VII - na qual funda-se essa propriedade $R$ - estipula que os números são proporcionais quando o primeiro é as mesmas partes do segundo que o terceiro é do quarto, então, só é possível ver a proporção adequada dos números dados quando for vista qual a parte que está tantas vezes no primeiro e tantas outras no segundo, qual a parte que está as mesmas vezes, respectivamente, no terceiro e no quarto, e quais as vezes que essas partes estão em cada número. Pode-se eficazmente determinar o valor do quarto número (sc. 273), sem jamais ver quais sejam as partes comuns (cinco e sete) e sem jamais ver como essas partes, embora sejam diferentes entre si (cinco $\neq$ sete), estão o mesmo número de vezes em 85 (dezessete vezes cinco) e em 119 (dezessete vezes sete), assim como em 195 (trinta e nove vezes cinco) e em 273 (trinta e nove vezes sete). Em suma, é possível ter certeza de que 273 é o único numero que está para 119 assim como 195 está para 85, sem sequer passar pela compreensão de como é, afinal, que 195 está para 85.

Pelo terceiro modo, identifica-se o número a partir de uma regra operatória muito eficaz, mas passa-se ao largo do conhecimento de que trinta e nove dezessete avos é a proporção entre 195 e 85 e entre 273 e 119. Trinta e nove dezessete avos é " $\rightarrow$ " quando $195 \rightarrow 85$. Aliás, sendo isso ignorado, fica-se sem saber que a causa de X ser 273, quando $119 \rightarrow \mathrm{X}$, é que este último valor não é outra coisa senão trinta e nove dezessete avos de 119; ignora-se que trinta e nove dezessete avos é a essência da proporção entre os quatro números dados. Sem esse conhecimento, a relação entre tais 
números permanece extrínseca: sabe-se que, havendo proporção, dá-se a propriedade $R$ dos números terem o produto dos meios igual ao produto dos extremos. Conversamente, a constatação dessa propriedade $R$ funciona como um sinal unívoco e não convencional que indica que esses números são proporcionais, ou seja, que dá-se a natureza geral das proporções. Mas, sem o provimento da essência e da causa da proporção entre os números apresentados, parece-me correto dizer que esse modo de perceber não está tão distante do conhecimento por sinais - e isso talvez explique o cuidado de Espinosa, no Tratado da Emenda, ao especificar o primeiro modo de perceber através do traço da convencionalidade (ad placitum), pois que ele aqui não comparece, embora compareça a função de índice que um signo possui (função desempenhada agora pela propriedade ou pelo efeito). Nesse sentido, é proveitoso observar que, na nota $h$ do parágrafo 21 do Tratado da Emenda, Espinosa afirma explicitamente que, sendo abstrato esse modo de perceber, a imaginação — que supostamente estaria estanque nos dois primeiros modos — imediatamente ("statim") entra a confundir as coisas; confusão que se consubstancia na imposição de nomes a isso que não passa de um aliquid inferido como suporte posto sob a propriedade ou na origem efeito constatado: "às coisas que [os homens] concebem abstrata, separada e confusamente, impõem nomes"334. Fica assim estabelecida uma tripla articulação: (i) a coisa que se pretendia conhecer, embora ainda desconhecida, é identificável através dos (ii) propria, que são índices não convencionais; e através da coextensividade destes últimos com a coisa, esta pode ser eficazmente designada por (iii) signos convencionais, pode ser nomeada sem equívocos, muito embora não se tenha produzido uma sua verdadeira e legítima definição. O terceiro modo de percepção vai além da mera cadeia associativa sensorial que caracteriza o primeiro modo de perceber, realiza inferências e tende a produzir definições, mas, nesse ponto, seu limite é o das definições nominais, eficazes se empregadas como marcadores ou índices mas, por isso mesmo, ainda restritas às funções do signo, sem condições de atingir, por si só, o nível da verdadeira idéia.

A despeito de sua eficácia identificatória - correlata a essa produção de signos inequívocos e não convencionais, fundados na contra-predicação dos propria (e.g. se quatro números têm a propriedade $R$, são ditos proporcionais, e se são ditos verdadeiramente proporcionais, devem ter propriedade $R$ ) $-\mathrm{o}$ terceiro modo de perceber "salta" uma etapa dedutiva, qual seja, precisamente aquela que faria o vínculo

${ }^{334}$ TIE 21, nota $h$ : "Nam iis, qua abstracte, seorsim et confuse concipiunt, nomina imponunt" 
intrínseco entre a conclusão (X é 273) e a premissa maior (X está para 119 assim como 195 está para 85) ${ }^{335}$ : falta a premissa menor, na qual estaria afirmado “Ora, 195 está para 85 como trinta e nove dezessete avos"; "logo, diria a conclusão, X está para 119 como trinta e nove dezessete avos". Ficaria assim a montagem do silogismo:

Maior : $\quad{ }^{\mathrm{S}}$ [o como X está para 119] $\mathrm{e}^{\mathrm{M}}$ [o como 195 está para 85].

Menor: Ora, ${ }^{\mathrm{M}}$ [o como 195 está para 85] $\mathrm{e}^{\mathrm{P}}$ [trinta e nove dezessete avos].

Conclusão: Logo, ${ }^{\mathrm{S}}$ [o como X está para 119] e ${ }^{\mathrm{P}}$ [trinta e nove dezessete avos].

Como foi dito, falta ao terceiro modo de percepção o conhecimento da premissa menor, ou seja, o conhecimento do conteúdo do termo médio - ${ }^{\mathrm{M}}$ [o como 195 está para 85] - , conteúdo que, nessa premissa, é explicitado no predicado ${ }^{\mathrm{P}}$ [trinta e nove dezessete avos]. Pelo terceiro modo, é possível chegar ao valor correto, mas apenas inadequadamente, ou seja, sem que seja possível enunciar a conclusão da forma como está exposta acima: tudo que se obtém é o valor 273 e nada mais, pois o termo médio, M, é tomado abstratamente e o seu predicado P encontra-se "velado". Assim, o que cabe agora explicar é de que maneira faz-se possível obter a premissa menor, na qual consta patente o predicado que o termo médio comunica à conclusão. Se isso puder ser feito, dar-se-á a superação do modo de percepção próprio aos matemáticos.

No momento em que foi introduzido este exemplo, em essência idêntico ao de Espinosa mas propositadamente montado com números cuja proporção é dificilmente visível, foi dito que o conhecimento de que “M ${ }^{\mathrm{M}}$ o como 195 está para 85] é ${ }^{\mathrm{P}}$ [trinta e nove dezessete avos]" - o conhecimento da premissa menor — proveio, sem contradizer a natureza geral das proporções conhecida pelos matemáticos, da apreensão da parte que está dezessete vezes em 85 e trinta e nove vezes em 195, a saber, cinco unidades. Aliás, é apenas de posse dessa parte que se chega à quantidade de vezes que ela está em 85 e em 195. Mas como chegar a essas cinco unidades? Essa parte apenas foi revelada alguns parágrafos acima mas não se disse de onde proveio tal valor. Em verdade, eu parti dele: multipliquei 5 por 17 e por 39 e produzi o primeiro par segundo a razão 39/17 e, depois, multipliquei 7 pelos mesmos números de vezes e obtive um segundo par que eu sabia, por isso, possuir a mesma razão. Essa perspectiva, por ser a do criador do exemplo, é privilegiada: apenas substituí 273 por X e perguntei pela

${ }^{335}$ Note-se que a premissa maior é o próprio enunciado do problema. 
proporção que, de antemão, já havia determinado. Mas essa perspectiva não é a de nenhum dos quatro modos de perceber. O enunciado espinosano do exemplo é claríssimo: "dados três números, procurar (quarere) o quarto que está [é] para o terceiro como o segundo para o primeiro" 336 . Trata-se de procurar e encontrar o quarto número, a partir dos outros que estão expressamente dados. Trata-se da perspectiva humana, interna à série dos modos finitos; não se trata da perspectiva divina.

O exemplo reproduz, no âmbito epistemológico, a perspectiva que se delineara no âmbito prático ao longo do Proêmio do mesmo Tratado, dedicado à busca da perfeição humana, na qual consiste a suprema felicidade. Assim, se esse exemplo está na base da escolha do melhor modo de perceber, pelo qual o fim - a felicidade — será obtido, ele deve diferenciar os quatro modos pelo percurso através do qual cada um chega - e, de fato, chega - ao mesmo resultado. Se o quarto modo assemelha-se em alguma coisa à perspectiva divina é porque, depois de encontrada a primeira parte comum, e após a determinação das vezes que ela figura no primeiro par de números, então, e só então, o homem do Tratado da Emenda poderá refazer o modo de produção do exemplo como se ele o tivesse criado, podendo gerar, inclusive, ilimitados outros pares de números com a mesma proporção. Repita-se, portanto, a pergunta central para a devida apreciação dos modos de perceber: como encontrar a adequada proporcionalidade; ou seja, uma vez que isso depende da descoberta daquela primeira parte comum que, no exemplo aqui criado, foi dito ser 5 , como chegar a ela?

Antes de responder, é oportuno notar que a superação da inadequação do terceiro modo de perceber, ou seja, a passagem para o quarto modo, não é o abandono de um procedimento matemático dedutivo, mas sim seu aprimoramento através da emenda do caráter meramente operatório que marca o terceiro modo. No texto do parágrafo 24 , é de uma forma compacta e contínua que a redação exprime a diferença entre o terceiro e o quarto modo a propósito do exemplo matemático:

"Entretanto [os matemáticos] não vêem a adequada proporcionalidade dos números dados, e se a vêem, não a vêem por força daquela proposição [de Euclides], mas intuitivamente, sem fazer nenhuma operação"337.

Dado o caráter construtivo das definições perfeitas preconizadas por Espinosa,

${ }^{336}$ TIE $§ 23:$ "Dantur tres numeri; quarit quis quartum, qui sit ad tertium, ut secundus ad primum"

337 TIE § 24: "Attamen adaquatam proportionalitatem datorum numerorum non vident; et si videant, non vident eam vi illius propositionis, sed intuitive, nullam operationem facientes" 
não creio que seja admissível considerar essa ausência de operações como uma mística passividade contemplativa. Além disso, ao dar como exemplo do conhecimento pelo quarto modo o saber que $2+3=5$, o texto espinosano também afasta a interpretação de que "nullam operationem facientes" signifique "sem fazer nenhuma espécie de conta, ou sem contar'. Em meu entender, essa cláusula vem, antes, para afastar certa forma específica de realização do procedimento de cálculo, a saber, justamente esta que é estritamente operatória, ou seja, que só é capaz de prover a indicação do que é procurado, através da aplicação externa de uma regra geral (derivada da contrapredicabilidade do proprium, que sempre acompanha o universal ${ }^{338}$ a que o caso é subsumido). "Sem fazer nenhuma operação" não significa um insight imediato, mas sim 'sem fazer um uso operatório da propriedade'. Se Espinosa diz "nullam operationem", talvez fosse o caso de investigar, por exemplo, a oposição entre operar e agir no vocabulário espinosano, mas isso ultrapassa os limites do presente artigo.

No que concerne ao quarteto de números do exemplo aqui proposto, uma forma de calcular o quarto proporcional que não seja meramente operatória é, como foi visto, aquela que calcula a relação " $\rightarrow$ ” no caso em que $85 \rightarrow 195$. Esse cálculo deverá produzir a premissa menor e permitir que a conclusão conte com todas as suas premissas. Mas esse próprio cálculo de " $\rightarrow$ " deve ser construtivo, isto é, deve efetuar, no caso concreto, a natureza geral das proporções e derivar a propriedade que sempre a acompanha, ou seja, deve, em primeiro lugar, achar (i) a parte que está tantas vezes em 85 e tantas outras em 195 e, em seguida, determinar (ii) essas vezes que tal parte está em um e em outro número. Só assim o procedimento será totalmente construtivo ou genético, pois da parte será construída, in concreto $^{339}$, a natureza geral das proporções,

${ }^{338}$ Note-se que esse universal corresponde à natureza da proporção [ $§ 24$ "natura proportionis"] e não aos meros nomes gerais. Trata-se da própria definição euclidiana dos números proporcionais, qual seja, segundo Matheron [(1986) p. 126], a Definição 20 do Livro VII dos Elementos: "números são proporcionais quando o primeiro é o mesmo múltiplo, ou a mesma parte ou as mesmas partes do segundo que o terceiro é do quarto". Isso, creio, abriria um caminho de pesquisa que talvez pudesse demonstrar que trata-se aí daquilo que, na Ética, será denominado como noções comuns. A crítica feita no Tratado não incide sobre a definição euclidiana da proporção, isto é, não incide sobre aquilo que pode corresponder a uma noção comum - o que comprometeria irremediavelmente o valor desse modo de percepção e faria com que o tratamento dado a ele pelo Tratado da Emenda fosse inarticulável com o tratamento dado pela Ética - mas sim ao uso que se satisfaz com a eficácia identificatória da propriedade que sempre acompanha esse universal. O cuidado que condiciona a possibilidade de um bom uso do terceiro modo de perceber é, antes de mais nada, a própria atenção que deve ser dada ao fato de que essa eficácia ainda não é conhecimento da essência, de que os propria não fornecem a definição. O maior perigo contido nesse terceiro modo advém, ironicamente, da própria certeza que por ele se instaura e que pode propiciar uma precoce satisfação ["non tamen satis tuta est"] a truncar a passagem do terceiro ao adequado quarto modo de perceber.

${ }^{339}$ É sabido que Espinosa considera os entes matemáticos como entes de razão "não existindo na Natureza qualquer objeto que lhe[s] corresponda" (TIE § 72). Assim, quando aqui se diz in concreto, isso não significa hipostasiar tais entes, mas adicionar-lhes um grau de determinação, como, por exemplo, ao se passar da 
isto é, uma legítima proporção particular “ $\rightarrow$ ”, e desta, por sua vez, será construída também concretamente - a unidade entre os quatro números, a qual, ainda uma vez, construirá o valor numérico buscado e que é dotado daquela propriedade $R$. Este último valor não terá sido, assim, inferido como um mero suposto admitido sob a propriedade de ter o produto de sua multiplicação pelo primeiro igual ao produto do terceiro pelo segundo. O quarto número terá sido, antes, gerado a partir da proporcionalidade concreta existente na relação do primeiro com o segundo número dado.

No já citado artigo de Alexandre Matheron, isso que aqui se caracteriza como a base do conhecimento construtivo da natureza e da propriedade da proporção in concreto, é procurado nos seguintes termos: "como podemos encontrar a maior medida comum entre os dois números dados e, então, encontrar também sua ratio?" ${ }^{340}$. Tirando todo o proveito da referência precisa que Espinosa faz à proposição 19 do Livro VII dos Elementos de Euclides, Matheron explora o professo conhecimento que nosso filósofo tinha da aritmética euclidiana e percorre os trechos dos Elementos conexos à referida proposição, buscando esclarecer o terceiro modo de perceber, mostrando que sua caracterização, sua limitação e o ponto em que se estabelece a diferença com o quarto modo eram muito claros ao leitor seiscentista que estivesse a par desse universo de referências aludido pelo texto do Tratado da Emenda. Assim, para responder à pergunta central, supra citada, partindo da Definição 20 e passando pelas proposições que geraram a proposição 19 do Livro VII dos Elementos, Matheron se reporta às proposições 1 e 2 do mesmo Livro. Nelas, é apresentado o procedimento conhecido como anthyphairesis. Esse procedimento, sintomaticamente exposto nas duas primeiras proposições do Livro VII, permite a obtenção da maior medida comum entre dois números dados (que não sejam primos). Se cabe à definição 20 do mesmo Livro onde se diz qual a natureza dos números proporcionais — afirmar que "números são proporcionais quando o primeiro é (...) as mesmas partes do segundo que o terceiro é do quarto", cabe à anthyphairesis, por seu turno, demonstrar como um número é "as mesmas partes" de outro.

O procedimento - cujo nome poderia ser grosso modo traduzido como 'contra subtração do resto' - consiste basicamente no seguinte: diante de dois números dados, $\eta$ e $\theta$, tal que $\eta<\theta$, subtrair $\varepsilon$ vezes o menor do maior afim de encontrar um resto $\rho$ que

consideração de um quadrado de lado $l$ e área $l^{2}$ para a consideração de um quadrado com lado composto por 5 unidades quaisquer e área composta por 25 dessas mesmas unidades. No texto de Espinosa, o equivalente dessa expressão - in concreto — é o genitivo datorum numerorum no parágrafo 24 do TIE.

${ }^{340}$ Matheron (1986) p. 127. 
seja menor do que $\eta$, quando se faz impossível uma nova subtração do mesmo número $\eta$; nesse ponto, repete-se o procedimento, agora entre $\eta$ e $\rho$, e assim por diante até que não haja mais resto ou resíduo (e se sempre há resíduo, trata-se de números primos). Por esse procedimento, sabe-se o que $\eta$ é para $\theta$ e o que $\theta$ é para $\eta$, pois é nisso que consiste a proporção, ou seja, agora segundo a letra do texto espinosano, em esse $a d^{341}$. Assim, o procedimento da anthyphairesis, ou seja, a descoberta da parte comum entre $\eta$ e $\theta$ e de quantas vezes essa parte comum está em cada um desses dois números, principiará como determinação de $\theta$ em termos de $\eta$, do que $\theta$ é para $\eta$, isto é, com a determinação de $\theta$ como sendo $\varepsilon$ vezes $\eta$ com um eventual resíduo $\rho<\eta$.

Um esquema geral ficaria da seguinte forma:

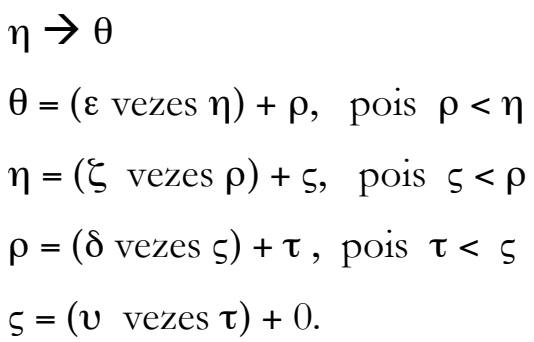

No momento em que não há mais resto, efetua-se a substituição, simplesmente fazendo valerem as igualdades. Não convém exprimir a substituição com símbolos, pois isso resultaria numa expressão muito extensa, dado que não seria possível efetuar as multiplicações. De toda maneira, uma vez que a forma do procedimento está apresentada, o que verdadeiramente importa é entender como dar-se-ia a anthyphairesis capaz de prover, no caso dos números aqui escolhidos, a aspirada premissa menor.

Ora, uma vez que 85 corresponde a $\eta$ e 195 corresponde a $\theta$, o procedimento começaria por um conhecimento que - equivalente a $2+3$ - Espinosa haveria de considerar como sendo do quarto modo, a saber: 195-85. O resultado dessa subtração simples é 110, comportando mais uma subtração de 85 , quando então é encontrado o resto 25 . E o procedimento prossegue como no esquema acima descrito ${ }^{342}$ : ${ }^{\eta} 85 \rightarrow{ }^{\theta} 195$

$1^{a}$ Subtração: ${ }^{\theta} 195-{ }^{\eta} 85=110$. Mas $110>{ }^{\eta} 85$. Logo, efetua-se mais uma

${ }^{341}$ TIE § 23: "Dantur tres numeri; quarit quis quartum, qui sit ad tertium, ut secundus ad primum /Dados três números, procurar o quarto que está [é] para o terceiro como o segundo para o primeiro"

${ }^{342}$ Para auxiliar na visualização da correspondência entre o esquema formal e o esquema concreto, será colocada, sobrescrita antes de cada número, a letra grega que é seu correlato no esquema formal apresentado. Isso pode tornar a leitura das expressões um pouco menos fluente, mas o leitor poderá simplesmente omitir as letras, e os valores numéricos tornarão claro o sentido das expressões. Por outro lado, a presença das letras sobrescritas (antes dos números, para evitar qualquer confusão com a grafia convencionada para potenciações) permite a marcação dos valores numéricos de forma que se possa acompanhar a movimentação de cada termo nas sucessivas substituições. 
subtração.

$2^{a}$ Subtração: $110-{ }^{\eta} 85=25$. Ora, $25<{ }^{\eta} 85$. Logo, não é possível efetuar mais uma subtração. Portanto, 25 corresponde ao resto $\rho$, e o número de subtrações, qual seja, 2, corresponde a $\varepsilon$. Chega-se, assim, à primeira expressão que realiza o esquema formal supra descrito:

I) ${ }^{\theta} 195=\left({ }^{\varepsilon} 2\right.$ vezes $\left.{ }^{\eta} 85\right)+{ }^{\rho} 25$.

Repete-se, então, o mesmo procedimento, agora determinando " 85 em termos do elemento residual, isto é, do resto ${ }^{\mathrm{P}} 25$ :

$1^{\text {a }}$ Subtração: ${ }^{\eta} 85-{ }^{\rho} 25=60$. Mas $60>{ }^{\circ} 25$. Logo, efetua-se mais uma subtração.

$2^{\text {a }}$ Subtração $60-{ }^{\rho} 25=35$. Mas $35>{ }^{\rho} 25$. Logo, efetua-se mais uma subtração.

$3^{\mathrm{a}}$ Subtração $35-{ }^{\rho} 25=10$. Ora $10<{ }^{\rho} 25$. Logo, não é mais possível efetuar uma subtração. Assim, chega-se à seguinte determinação de ${ }^{\eta} 85$ em termos de ${ }^{\rho} 25$, na qual ${ }^{\varsigma_{3}} 3$ é o número de vezes que ${ }^{\circledR} 25$ cabe em ${ }^{\eta} 85$, deixando um resíduo de ${ }^{5} 10$ unidades, que evidentemente não podem ser determinadas em temos subtrações de ${ }^{\rho} 25$. Assim:

II) ${ }^{\eta} 85=\left({ }^{\zeta} 3\right.$ vezes $\left.{ }^{\rho_{2}} 25\right)+{ }^{\varsigma} 10$

Repete-se, então, o mesmo procedimento, agora determinando ${ }^{\rho} 25$ em termos do elemento residual, isto é, do resto ${ }^{\varsigma} 10$ :

1 Subtração: ${ }^{\rho} 25-{ }^{5} 10=15$. Mas $15>{ }^{5} 10$. Logo, efetua-se mais uma subtração.

$2^{\text {a }}$ Subtração: $15-{ }^{5} 10=5$. Ora $5<{ }^{5} 10$. Logo, apenas dois $\varsigma$ cabem em $\rho$, isto é, ${ }^{\delta} 2$ vezes 10 em 25, deixando um resíduo de ${ }^{\top} 5$. Portanto:

III) ${ }^{\rho} 25=\left({ }^{\delta} 2\right.$ vezes $\left.{ }^{\varsigma} 10\right)+{ }^{\tau} 5$.

Repete-se, então, o mesmo procedimento, agora determinando ${ }^{5} 10 \mathrm{em}$ termos do novo elemento residual, isto é, do resto ${ }^{\top} 5$ :

1 Subtração: ${ }^{5} 10-{ }^{\tau} 5=5$. Ora, é possível realizar mais uma subtração:

$2^{\text {a }}$ Subtração: $5-{ }^{\tau} 5=0$.

Assim, havendo sido necessárias apenas 2 subtrações, deve-se dizer que ² vezes ${ }^{\top 5}$ é igual a ${ }^{5} 10$.

IV) ${ }^{\varsigma} 10=\left({ }^{v} 2\right.$ vezes $\left.{ }^{\tau} 5\right)$

Nada ficou faltando a determinar em termos de ${ }^{\tau} 5$. A parte ${ }^{\varsigma} 10$ é suficientemente definida em termos de ${ }^{\tau} 5$, ela é $2\left(^{\tau} 5\right)$ e nada mais $(+0)$. E, assim sendo, esta última parte não precisará ser determinada em termos de outra, a qual figuraria como algo adicionado, algo que ela não teria abrangido. Muito pelo contrário: realizando as 
substituições, vê-se que todas as outras partes podem ser determinadas em termos de `5. Este não é, portanto, um "novo elemento residual", pois é absolutamente "absorvido" por todas as outras partes anteriores, bem como pelos valores totais dos quais se partiu. Veja-se, pois, o conjunto de expressões:

$$
\begin{aligned}
{ }^{\theta} 195 & =\left({ }^{\varepsilon} 2 \text { vezes }{ }^{\eta} 85\right)+{ }^{\rho_{25}} \\
\eta_{85} & =\left({ }^{\varsigma} 3 \text { vezes }{ }^{\rho_{2}} 25\right)+{ }^{{ }} 10 \\
{ }^{\rho} 25 & =\left({ }^{\delta} 2 \text { vezes }{ }^{\varsigma} 10\right)+{ }^{\tau} 5 \\
{ }{ }_{10} & =\left({ }^{2} \text { vezes }{ }^{\tau} 5\right) .
\end{aligned}
$$

Até aqui, cumpriu-se a primeira tarefa necessária à determinação da premissa menor: (i) achar a parte que está tantas vezes em 85 e tantas outras em 195, qual seja, aquela que fora revelada sem que houvesse sido demonstrado de onde ela teria provindo: 5. Realizando as substituições, será automaticamente cumprida a segunda tarefa: (ii) achar essas vezes que tal parte está em um e em outro número. Dessarte, cumpre eliminar progressivamente todos os elementos não numéricos exceto a parte $\tau$, que agora já se sabe que é 5 , como é 5 e por que é 5 .

A expressão VI, que encerrou a anthyphairesis, foi a seguinte: " $510=(2$ vezes `5)". Assim, deve-se dizer que:

$$
{ }^{5} 10=2 \tau \text {. }
$$

Substituindo ${ }^{5} 10$ por $2 \tau$ nos lugares em que o termo figura na expressão III, isto é, em "م25 $=\left({ }^{\circledR} 2\right.$ vezes $\left.{ }^{\varsigma} 10\right)+{ }^{\tau} 5 "$, conclui-se que "م25 $=(2$ vezes $2 \tau)+\tau$ ", chegando, então, a uma determinação de ${ }^{\rho} 25$ em termos de $\tau$ :

$$
\rho_{25}=5 \tau \text {. }
$$

Subindo à expressão II — “" $85=\left({ }^{\zeta} 3\right.$ vezes $\left.{ }^{\rho} 25\right)+{ }^{\varsigma} 10 "$ - e substituindo ${ }^{\rho} 25$ por $5 \tau$, bem como ${ }^{5} 10$ por $2 \tau$, obtém-se uma determinação de ${ }^{n} 85$, isto é, do primeiro número da proporção, em termos de $\tau$, ou seja, sabe-se quantas vezes a parte comum está no primeiro número: ${ }^{\eta} 85=(3$ vezes $5 \tau)+2 \tau$ e, portanto :

$$
\eta 85=17 \tau \text {. }
$$

Ora, como o segundo número da proporção, ${ }^{\theta} 195$, foi determinado na expressão I como sendo igual a $\left({ }^{\varepsilon} 2\right.$ vezes $\left.{ }^{\eta} 85\right)+{ }^{\circledR} 25$, realizando as devidas substituições obtém-se o número de vezes que a parte comum $\tau$ está nesse segundo número: ${ }^{\theta} 195=(2$ vezes $17 \tau)+5 \tau$. Dessarte, completa-se a segunda tarefa dizendo que

$$
{ }^{\theta} 195=39 \tau \text {. }
$$


Através desse procedimento, foram realizados cálculos simples, todos do mesmo tipo que $3+2=5$. Tudo se passou, pois, dentro do quarto modo de perceber. Se foi apresentado, em primeiro lugar, o esquema formal da anthyphairesis, foi apenas para deixar bem distintos os passos do procedimento. Não se deve suspeitar que se trate aqui de uma nova regra operatória a ser aplicada cegamente. Trata-se, bem ao contrário, de um procedimento construtivo. Nada está sendo ditado do exterior: nem do exterior que é a autoridade, nem do exterior que é um caso particular frente a outro caso particular (o qual, o primeiro jamais pode abarcar como a regra de ambos). A anthyphairesis emerge apenas da manipulação das grandezas dadas, da experiência de flexão de uma sobre a outra; o esquema formal não é obtido por generalização, pois sua validade irrestrita é congênita à sua descoberta. A experiência construtiva - e é apropriado falar de experiência, visto que a lida é com grandezas particulares, embora seja uma experiência intelectual - é descoberta e apresentação probatória a um só tempo. Aqui se vê uma legítima definição genética, na qual, sempre dentro do quarto modo, entende-se o modo de constituição interna da proporção dada. A partir das sucessivas subtrações, que constituem, em última instância, um processo de divisão, é feita, por assim dizer, a anatomia da proporção, na qual a primeira fase (i), que encontra a parte, é como que morfológica, e a segunda (ii), que determina como essa parte produz os números dados, é como que fisiológica.

Embora a descrição aritmética da anthyphairesis seja prolixa, ela é apenas a narração numérica do que julgo ser um procedimento construtivo geométrico, comparável ao tipo de expediente empregado na definição genética do círculo. Suponha-se que os valores 85 e 195 sejam, cada um, um segmento de reta, respectivamente $\eta$ e $\theta$. Superponha-se o menor sobre o maior, unidos em uma extremidade. O recobrimento será parcial, ou seja, o menor caberá 2 vezes no maior, que ficará descoberto num sub-segmento $\rho$. Faça-se, então, a superposição desse subsegmento sobre o segmento $\eta$, o qual também não será plenamente recoberto, ficando exposto num resto 5 , etc., até que se ache um pequeno sub-segmento que, sem fragmentar-se, recubra homogeneamente tanto o segmento $\eta$ quanto o segmento $\theta$, bem como cada um dos demais sub-segmentos descritos pelas sucessivas superposições ( $s c$. $\rho, \varsigma$, etc.). Trata-se, pois, de uma figuração espacial de algo que se encontra no todo e em cada uma das partes parciais. Chamemo-lo de $\tau$, e também de parte total, pois é como um definiens absolutum, que define todas as partes mas não se define por 
nenhuma outra (na relação entre 195 e 85, bem entendido).

Uma expressão gráfica desse procedimento poderia ser apresentada através da seguinte figura:

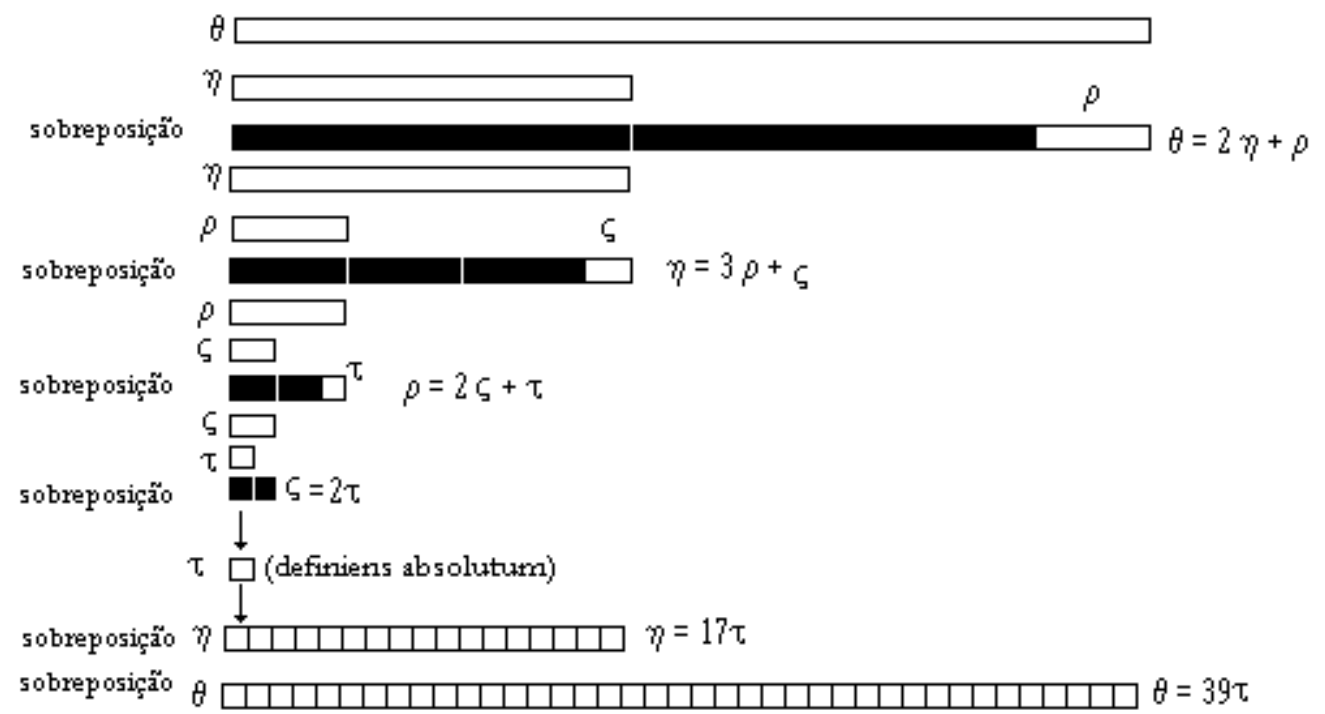

Esse esquema deixa bem mais claro por que a anthyphairesis procede do modo descrito algébrica e numericamente. Mas a grande vantagem dessas outras descrições, apresentadas em primeiro lugar, é que sua natureza discursiva permite uma aproximação com a linguagem natural, de modo que, confirmando o que foi dito sobre tratar-se aí de um expediente definitório, pode-se atentar à anthyphairesis e nela reconhecer o esquema de definição presente, por exemplo, nos textos da Ética. Nesta última, a passagem do definendum para o definiens é um procedimento intelectual (intelligo) e lingüístico (dico, appello,voco, etc) que se exprime nas páginas do livro como articulação de um registro preponderantemente lexical (os núcleos dos definiendos são predominantemente substantivos) e um registro sintático, onde a ocorrência de outros verbos, outros nomes e elementos sincategoremáticos, tende a permitir uma complexidade dinâmica de ações e coordenações. Ora, quê pede um problema de proporção? Que se diga o que algo é para outro algo. Não se trata, pois, da definição da essência de cada coisa em si mesma considerada, porquanto o que se pede é uma relação, um esse ad. Todavia, quando Espinosa critica o terceiro modo de percepção e os matemáticos que o tipificam, diz que estes não percebem adaquatam proportionalitatem. Isso torna compreensível que é o caso de se falar em uma essência da proporção entre os números dados. É essa essência que a anthyphairesis define. Para 
tanto, o primeiro passo é definir um número pelo outro. Parafrasearei, pois, ambos os discursos - o de Espinosa e o de Euclides — se disser: Per 195 intelligo $2 * 85+25$. Eis aí a passagem de um elemento quasi lexical, um símbolo de certa quantidade, para um campo sintático, no qual, além de outros símbolos de quantidades, há também símbolos de operações e, portanto, dinamismo e coordenação. Assim, diante dessa definição, não se deve simplesmente fazer a conta, pois que isso reenviaria à identidade $195=195$. O procedimento da anthyphairesis como que pede que, novamente, sejam definidos os elementos definientes um pelo outro, transformando o definiens em definiendum, aprofundando a definição, intensificando a complexidade sintática, introduzindo novos cálculos, indo cada vez mais longe da opacidade de 195=195, isto é, do mero "195", até achar um definiens absolutum, a partir do qual, então, 195 e toda a complexidade gerada podem ser entendidos integralmente, revelando a articulação interna das identidades (195=195; 85=85) em relação recíproca: Per 85 intelligo 3*25+10; Per 25 intelligo $2 * 10+5$; Per 10 intelligo $2 * 5$.

Este último termo, 5, não é a menor parte de que 195 ou 85 são constituídos. Afinal, 1 é uma parte menor, bem como $1 / \infty$, sendo um contra-senso a busca da menor de todas as partes. Mas 5 é o termo de referência último quando é pedida a maior de todas as parte comuns entre 195 e 85 . É possível, então, dizer que a reconstrução factível (fácil) a partir dessa parte, fornece uma percepção adequada da proporção particular dada e — por que não dizer ? - uma idéia simples. Pode parecer paradoxal que, em meio a tantos desdobramentos e substituições em inúmeras etapas de cálculo, se fale de simplicidade. A pura idéia de, por exemplo, 195 não seria mais simples? Não, pois, como foi dito, assim apresentada como um dado bruto ela é opaca, é quase um nome, ao passo que, para Espinosa, as idece simplices são justamente os conceitos formados de maneira construtiva, os quais, por um lado, têm seus elementos internos ligados por relações que são visíveis pelo intelecto e, por outro, não apresentam nenhuma propriedade que já não estivesse determinada por essas mesmas relações que transparecem na construção do conceito. Essa simplicidade do complexo, ao invés de uma contradictio in adjecto, torna-se bastante plausível quando se considera que aqueles que procedem pelo terceiro modo, ou seja, não realizam a anthyphairesis, não chegam à parte total e, portanto, não podem captar a proporcionalidade que torna reciprocamente inteligíveis os números dados. Seu procedimento é mais rápido, mas, como se pôde ver, não supera a justaposição das propriedades e, sob elas, a admissão da coisa. De posse da parte total, ao contrário, forma-se o conceito do que 195 é ad 85 e do 
que 85 é ad 195, a saber, respectivamente, 39(5) e 17(5) e, assim, é lícito dizer: "Per 85 ad 195 intelligo 17*5" e "Per 195 ad 85 intelligo 39*5". Da opacidade de 119 e 85 chega-se à transparência de sua estrutura interna através do estabelecimento de suas relações recíprocas:

Aqui efetivamente se $v \hat{e}$ a essência da proporção existente entre os números dados. Ao menos tanto quanto se vê a essência íntima do círculo em sua definição genética.

É notável o modo prolixo pelo qual a anthyphairesis resolve o que qualquer outro matemático resolveria muito rápida e eficazmente apenas com base na propriedade $R$ dos números subsumidos à natureza da proporção. Mas o que importa no exemplo espinosano é o valor intrínseco do procedimento e não o resultado que se desprende ao final do processo, uma vez que as quatro maneiras tem condições de chegar ao mesmo resultado. A qualidade da quarta maneira é que ela provê a estrutura da proporção, válida para qualquer par de números que estejam um para o outro segundo a mesma ratio. Assuma-se cada uma das partes representadas na figura supra como sendo um mesmo número e some-se o total de cada segmento, repita-se, depois, o mesmo procedimento com outro número, e assim por diante: será obtida uma infinidade de diferentes pares, todos, porém, com a mesma relação recíproca, todos produzindo esse mesmo desenho, esse mesmo esquema. Aliás, foi assim que o presente exemplo foi construído. Tal desenho é a representação gráfica de “ $\rightarrow$ ”, quando $85 \rightarrow 195$. O segmento menor tem 17 vezes aquilo que o maior tem 39. O segmento menor é, portanto, dezessete trinta-e-nove avos do maior. O qual, por sua vez, possui 39 vezes aquilo que o menor possui 17. E o enunciado que, da mesma maneira, descreve a relação do maior para o menor, é exatamente a premissa menor que se procurava: ${ }^{\mathrm{M}}[\mathrm{o}$ como 195 está para 85] é ${ }^{\mathrm{P}}$ [trinta e nove dezessete avos]. Dá-se o termo médio e o predicado que ele comunicará ao sujeito da premissa maior na conclusão. Segue-se daí que o quarto número proporcional deve conter em si 39 vezes aquilo que 119 contém 17. E qual a parte que está 17 vezes em 119? Seria tentador simplesmente dividir 119 por 17. Mas o procedimento que tem por modelo a anthyphairesis sugere que os próprios procedimentos sejam desconstruídos em seus elementos geradores comuns. 
Quê é afinal uma divisão? Ora, como foi dito, é uma soma de subtrações, assim como uma multiplicação é uma soma de somas. Não há afastamento do esquema $3+2=5$, com a diferença que agora também são somados os próprios eventos de efetuação; e.g. $(+)+(+)=2(+),(-)+(-)+(-)=3(-)^{343}$, etc. $)$. Dessarte, deve-se perguntar: quê é dividir 119 em 17 ? É contar quantas efetuações, quantos atos de subtração de 17 podem ser realizados a partir de 119 - o que, espacial ou extensamente, equivale a contar quantas vezes 119 contém 17 ou quantas vezes 17 "recobre" ou "cabe" em 119 (ou ainda, quantas vezes 119 pode se dobrar, se fletir em 17 como sua parte). Assim, sem que se abandone o quarto modo de percepção, repete-se aquele movimento que é o mais simples no interior da rotina da anthyphairesis, e se conta: $1^{\text {a }}$ Subtração: $119-17=$ 102; $2^{\text {a }}$ Subtração: $102-17=85$; $3^{\text {a }}$ Subtração: $85-17=68 ; 4^{\text {a }}$ Subtração: $68-17=$

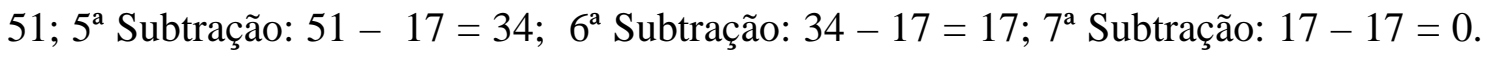
Dessarte, se 119 é perfeitamente recoberto por 7 grupos de 17, o será também por 17 grupos de 7, e com isso é encontrado o que se pedia, a saber, uma parte que está, inteira, 17 vezes em 119 inteiro: 7. Finalmente, o quarto número será obtido pela simples composição do segmento maior contando 7 em cada parte comum. Defina-se, pois, 273 como 39(7). O cerne do procedimento é definir um número pelo outro $-195=$ $(39 / 17) * 85-$ e, com isso, definir dois outros $-119=(39 / 17) * 273$. A lacuna $\rightarrow$ agora revela seu conteúdo: (39/17). É isso que é uma proporção: esse ad ut esse ad. Trata-se de uma relação entre relações e, por isso, não julgo nocivo o anacronismo quando digo que o quarto modo apreende, in concreto, uma estrutura.

Ora, definir proporções não é tarefa de pouca importância na filosofia espinosana. Para tomar apenas alguns exemplos, basta lembrar que o princípio de individuação dos entes físicos é uma proporção (ratio) constante de movimento e repouso entre as partes dos corpos: porções podem ser retiradas e repostas; mantida a ratio, o indivíduo persevera ${ }^{344}$. Não havendo, no universo espinosano, criação ou

343 Pergunto-me se isso não poderia ser comentado através das noções de "essência formal" e "essência objetiva". Pois, assim como numa idéia a essência formal é o seu ser um evento mental, um ato de pensar, e a essência objetiva é o conteúdo pensado nesse ato, assim também, ao serem engendradas, das duas operações mais simples (adição e subtração), as duas outras mais complexas (multiplicação e divisão), faz-se uma distinção entre — por assim dizer — a "quantidade formal" dos eventos e sua "quantidade objetiva". Ou melhor, além dessa distinção, realiza-se uma reflexão na qual a quantidade formal de uma operação (e.g.7 subtrações) passa a ser contida como quantidade objetiva (e.g. 7 é o valor, o número, que figura como resultado de uma divisão, quando um numero permite 7 operações de subtração de um outro número; o primeiro 7 é uma quantidade objetiva na operação de dividir, e o segundo 7 é uma quantidade formal na operação de subtrair).

${ }^{344}$ Cf. Ética II, def. depois do Lema 3: “Cum corpora aliquot (...) eodem aut diversis celeritatis gradibus moventur ut motus suos invicem certa quadam ratione communicent, illa corpora invicem unita dicemus et omnia simul unum corpus sive individuum componere quod a reliquis per hanc corporum unionem 
aniquilamento, a noção mesma de morte é comentada pela de perda de proporção:

"Mas é de notar aqui que entendo que o Corpo sofre a morte quando suas partes se dispõem de tal maneira que obtenham entre si outra razão (proporção) de movimento e de repouso"345.

E, no contexto cognitivo, a propria relação entre as idéias e os ideados é derivada do que uma idéia é para outra (causa ou efeito) e do que um ideado é para outro (causa ou efeito), e de como as partes internas de cada um estão entre si (truncadas ou coordenadas).

A exclusão espinosana da interação causal entre atributos - que evita a incidência naquele mistério, equivalente ao da criação ex nihilo, que é a produção de um efeito extenso a partir de uma causa totalmente inextensa, ou vice-versa — faz com que a relação das idéias com seus ideados seja derivada das relações, intra atributivas, das idéias entre si e dos ideados entre si. Aliás, entre os intérpretes da filosofia espinosana, o não cruzamento dos atributos gerou uma noção de paralelismo, segundo a qual, como em retas paralelas, pensamento e extensão só se "encontrariam" no infinito da substância. A despeito da beleza e de algum ponto elucidativo que essa comparação possa conter, ela peca por desconsiderar que há, sim, algo que "cruza" os atributos, a saber, aquilo mesmo que cruza os pares proporcionais: “ $\rightarrow$ ”, a mesma ratio.

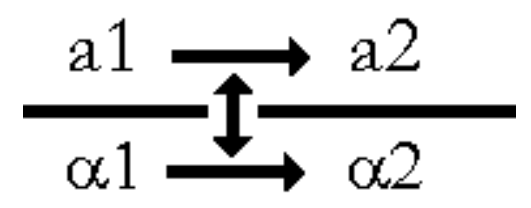

distinguitur / Quando alguns corpos (...) são movidos com o mesmo ou diversos graus de celeridade de maneira que seus movimentos comuniquem entre si uma razão (proporção) certa, diremos que esses corpos são unidos entre si e que todos simultaneamente compõem um corpo ou indivíduo, o qual se distingue dos demais corpos por essa união". Na seqüência desse mesmo conjunto, conhecido como "pequena física", leia-se, por exemplo, o lema V: "Si partes individuum componentes majores minoresve evadant, ea tamen proportione ut omnes eandem ut antea ad invicem motus et quietis rationem servent, retinebit idem individuum suam naturam ut antea absque ulla forma mutatione / Se as partes componentes do indivíduo tornam-se maiores ou menores, mas na proporção em que todas entre si conservam a mesma razão de movimento e repouso como antes, o indivíduo reterá igualmente a sua natureza como antes, sem mutação alguma da forma". Dessa "pequena física" é derivada uma fisiologia mecânica, de modo que esse processo supra descrito pode passar a ser considerado como um processo de aumento ou diminuição de massa corporal, como o crescimento ou o emagrecimento. E outros processos, tais como deslocamento, alimentação, respiração, excreção, etc., também derivados dessa "pequena física", sempre obedecendo as noções básicas de ratio e proportio.

345 Ética IV, prop 39, escólio. "Sed hîc notandum, quòd Corpus tum mortem obire intelligam, quando ejus partes ità disponuntur, ut aliam motûs, \& quietis rationem ad invicem obtineant" 
$\mathrm{Na}$ figura acima, as setas horizontais devem ser lidas como "est ad" e a seta vertical deve ser lida como " $u t$ ” mas também como "idem est”, pois é uma só e a mesma proporção (e.g. 17/39) que está presente simultaneamente nos dois pares distintos. A seta vertical é aquilo que, na proposição 7 de Ética II — de cujo escólio originou-se a imagem do paralelismo - é afirmado como o mesmo entre idéias e coisas: ordo et connexio $^{346}$. É tendo isso em mente que devem ser lidas algumas afirmações do Tratado da Emenda:

"A razão que há entre duas idéias [é] a mesma que a razão que há entre as essências formais daquelas idéias" 347 .

Talvez haja alguma preocupação em saber se, em tal frase, essas essências formais das idéias não seriam, ao invés dos ideados, as próprias essências formais constitutivas das idéias. Ora, isso não faz qualquer problema, pois, se assim for, ao invés de um novo paralelismo, o que estará sendo estabelecido é um novo cruzamento, pela "eadem ratio", entre o plano formal e o plano objetivo no interior do próprio pensamento. E quanto à relação das idéias com os ideados, também o Tratado da Emenda reafirma inequivocamente:

"Adicione-se que a idéia se porta objetivamente do mesmo modo como seu próprio ideado se porta realmente. Se, pois, fosse dado algo na Natureza que não tivesse nenhum comércio com outras coisas, e se disso também fosse dada uma essência objetiva, a qual devesse convir exatamente com a formal, também nenhum comércio teria com outras idéias, isto é, nada dela poderíamos concluir; e, ao contrário, aquelas que têm comércio com outras coisas, como são todas que existem na natureza, serão entendidas e suas essências objetivas terão o mesmo comércio, isto é, outras idéias serão deduzidas delas, as quais, de novo, terão comércio com outras, e assim crescem os instrumentos para prosseguir ulteriormente",348

O "comércio" entre as coisas, de um lado, e entre as idéias, de outro, explica

${ }^{346}$ Ética II, prop 7: "ordo \& conexio idearum idem est ac ordo \& conexio rerum / a ordem e a conexão das idéias é a mesma que a ordem e a conexão das coisas". Itálicos meus.

347 TIE § 38: "ratio, quœe est inter duas ideas, sit eadem cum ratione, qua est inter essentias formales idearum illarum”.

${ }^{348}$ TIE § 41: "Adde quod idea eodem modo se habet obiective, ac ipsius ideatum se habet realiter. Si ergo daretur aliquid in natura, nihil commercii habens cum aliis rebus, eius etiam si daretur essentia obiectiva, qua convenire omnino deberet cum formali, nihil etiam commercii haberet cum aliis ideis, id est, nihil de ipsa poterimus concludere; et contra, qua habent commercium cum aliis rebus, uti sunt omnia qua in natura existunt, intelligentur et ipsorum etiam essentice obiectiva idem habebunt commercium, id est, aliae idea ex eis deducentur, qua iterum habebunt commercium cum aliis, et sic instrumenta ad procedendum ulterius crescent". Itálicos meus na tradução. 
Espinosa na nota $p$ desse parágrafo 41, é produzir e ser produzido: producere aut produci. Ora, quê é dizer "Per 195 ad 85 intelligo 39*5" senão entender 195 literalmente - como um produto das 39 maiores partes comuns que se determinam na relação com 85, o qual, por sua vez, é produzido por 17 dessas mesmas partes? Trinta e nove dezessete avos de 85 - ou seja " $85 \rightarrow$ ” — produzem 195.

Retomando os números pequenos do exemplo de Espinosa, cumpre perguntar: quê é estabelecer o quarto número proporcional na série 2, 4, 3, X? É estabelecer uma relação entre 4 e X mediante a relação que 4 tem com 2 e que $X$ há de ter com 3. Tratase de estabelecer uma relação entre dois termos (4 e X) mediante a identidade de suas relações com dois outros. Quais são esses dois outros termos? Ora 2 e 3. E qual a relação entre 2 e 3 ? Aqui se vê a boa escolha dos números empregados por Espinosa: 2 e 3 são números primos, ou seja, números primeiros, divisíveis apenas por si mesmos e pela unidade, não sendo possível, dessarte, uma anthyphairesis entre eles. Pondo os dois números diante dos olhos, formula-se a pergunta: o que um é para o outro? Qual a proporção deles entre si? Ora, ao se forçar uma anthyphairesis, 2 seria subtraído de 3 e deixaria o resto 1, que já seria o definiens absolutum, aquele anteriormente marcado com a letra grega $\tau$. Assim, efetuadas as substituições, chegar-se-ia à conclusão de que $2=2 \tau$ e que $3=3 \tau$, ou seja, que $2=2$ e que $3=3$, e o procedimento apenas retornaria circularmente - ao ponto de partida. Mas, estabelecida a relação de 2 com 4 e de 3 com 6 , pode-se dizer que $2 \rightarrow 4$ assim como $3 \rightarrow 6$. A expressão "assim como" mostra que a coordenação intrapares estabelece uma outra relação extra pares ou interpares, tornando possível entender 2 em termos de 3 e vice versa, pois um está para o outro, igualmente, como sendo, cada um, o meio de seu próprio dobro. E se isso parece um truísmo, pois todo número é o meio de seu dobro, que não cause espanto, então, caso se diga que a proposição 7 de Ética II deve ser entendida como uma verdade eterna, pois nela se demonstra que tudo segue a mesma ordem e conexão, a mesma coordenação, a mesma syntaxis, seja no pensamento, seja na extensão. Esta proposição se demonstra apenas pelo axioma 4 de Ética I - "O conhecimento do efeito depende do conhecimento da causa e o envolve"349 -, o qual poderia ser parafraseado da seguinte maneira: o conhecimento da causa está para o conhecimento do efeito exatamente da mesma maneira como a causa está para o efeito: envolve aquilo de que depende, como o dobro depende do meio e o envolve.

${ }^{349}$ Ética I, ax. 4: "Effectus cognitio a cognitione causa dependet et eandem involvit". 
Se foi permitido a outros intérpretes de Espinosa, afim de comentarem a relação dos atributos entre si e destes com a substância, cunhar aquela imagem das retas paralelas que se encontram no infinito, que então seja dada aqui a licença para elevar à condição de modelo onto-gnoeseológico esse exemplo da quarta proporcional, fornecido por nosso próprio filósofo, a fim de comentar a percepção e seus modos. Além de valerse de um texto do autor, esse uso permitirá sentir a agudeza discreta do engenho retórico espinosano, pois que ela se manifesta tanto na riqueza de sua prosa quanto na densidade compacta do exemplo matemático. A escolha desses quatro números não é gratuita no Tratado da Emenda: 2 e 3 são números "primeiros", de sorte que, caso se tente encontrar a maior medida comum entre ambos, isto é, caso se aplique anthyphairesis, só será encontrada a unidade. Se o estabelecimento de proporções, pelo quarto modo, consiste em definir um número pelo outro, deve-se dizer que números primos são aqueles que só se definem por si mesmos e pela unidade. Creio ser lícito, pois, elevar esse fato à condição de modelo da própria relação ontológica entre atributos e substância e dizer que pensamento e extensão são "entes primos" entre si, entes "primeiros", que só se definem por si mesmos e pela substância, a qual, como a unidade, é definiens absolutum, pois nada sem ela pode ser concebido.

Fora da relação intrapares, idéias e corpos não se comunicam, assim como números primos. A explicação da ocorrência de percepções depende, pois, de que a união entre a mente e o corpo seja entendida como uma união entre "primos", ou seja, como sendo uma relação entre relações. Se essa é uma das mensagens do exemplo escolhido por Espinosa, seu engenho retórico se tornará ainda mais impressionante se os números escolhidos no Tratado forem comparados aos escolhidos na Ética, bem como os modos de percepção que em cada uma dessas obras introduzem valores numéricos. No Tratado da Emenda, 2, 4, 3, 6, são números apresentados como constituindo uma proporção simples, na qual o quarto número per se patet. É desse tipo de caso simples que precisamente a experientia faz axiomas universais: experimenta que o produto do segundo pelo terceiro, ao ser dividido pelo primeiro, é igual ao número que já fora conhecido sem esta operação, e daí conclui que essa operação é sempre boa para encontrar o quarto número proporcional. O que é mais característico da experiência não é o modo de obtenção do valor 6, mas o modo de conclusão do valor epistêmico da operação experimentada $(\mathrm{sc} .(3 * 4) / 12=6)$. Assim como os matemáticos, os empíricos não chegam a conhecer a adequada proporcionalidade através da mesma operação que concluíram ser boa sempre: se a viram, foi intuitivamente. A Ética II, no escólio 2 da 
proposição 40, diz que, dados números simplíssimos, como 1, 2, 3, ninguém deixa de ver que o quarto proporcional é 6. Na Ética, já se parte do 1, como que exprimindo no exemplo o percurso realizado pela Parte I. O primeiro número do primeiro par já é a unidade, definiens absolutum de todos os outros números do quarteto: todos são definíveis por ele. No Tratado da Emenda, o primeiro número do primeiro par é primo em relação a primeiro número do segundo par: 3 não se define por 2, como que comentando matematicamente o exemplo da "união" entre a alma e o corpo. Mas o que é realmente impressionante, é que não há números cuja relação de primos entre si seja mais patente do que 2 e 3, o que revela a penetração "retórica" desse aspecto do exemplo matemático na esfera da qual parte a experiência. Em meu entender, por ser próprio à perspectiva do Tratado, em oposição à da Ética, dialogar com a imaginação, penetrar em seu interior e transformá-la, é que Espinosa não escolhe os números 1, 2, 3, 6 mas $\operatorname{sim} 2,4,3,6$.

É possível conhecer que dois números são primos entre si através da anthyphairesis. E é exatamente isso o que se demonstra logo na primeira proposição do Livro VII dos Elementos:

"sendo dados dois números desiguais, e o menor sendo 'sempre e a cada vez subtraído de novo, ${ }^{350}$ do maior, se o número que é deixado nunca mede o anterior a ele até que uma unidade seja deixada, os números originais são primos entre si”, ${ }^{351}$.

Esse, aliás, é um teste para saber se dois números são primos. Mas, no Tratado da Emenda, cuja perspectiva própria se constitui no diálogo com a imaginação, não se pode exigir que o teste seja feito. É preciso partir de números simples tanto para exprimir o que é comensurável, quanto o que não é comensurável e, sobretudo, como os não comensuráveis se relacionam.

\footnotetext{
${ }^{350}$ Esta é uma tentativa de traduzir o particípio $\alpha v \theta v \phi \alpha \iota \rho o v \mu \varepsilon v o v$, correspondente do andamento do processo de anthyphairesis, que Heath (1952) traduz como "subtracted in turn".

${ }^{351}$ Tradução minha a partir da trad. inglesa de Heath [Euclides (1952), Livro VII, prop. 1].
} 


\section{Conclusão}

A situação epistêmica produzida pelo terceiro modo de percepção, tipificada pelas personagens conceituais chamadas de "os matemáticos" 352 , não possui todas as denominações intrínsecas da idéia verdadeira, pois não mostra como e por que algo é ou é feito (quomodo et cur aliquid sit, aut factum sit). Ela é marcada, ao contrário, sobretudo pela denominação extrínseca, isto é, pela correspondência - ou convenientia, nos termos espinosanos - com o ideado. Como julgo haver demonstrado, o caráter "certeiro" dessa correspondência obtida pela razão significa, no Tratado da Emenda, o êxito para, através de uma regra, predizer e controlar, como se vê pelo exemplo matemático proposto por Espinosa: 6 é o quarto número proporcional, quando os outros três são 1,2,3 ou 2,4,3, e não pode não ser 6. Mas existe, sim, algo de criticável na razão, apesar desse sucesso positivo e incontestável: por esse modo, não se conhece a causa ou razão (e neste caso, tal razão é literalmente a ratio) que fundamenta internamente essa necessidade nos casos concretos particulares. É por isso que se faz imprescindível um cuidado a mais para que não se dê a ingerência da imaginação e, conseqüentemente, a possibilidade do erro. Ou seja, o terceiro modo de percepção, por si só, não é suficiente: sozinho, sem esse cuidado, é apenas causa parcial da certeza que produz diante do efetivo, do dado, contendo, pois, um traço de dependência e, portanto, de passividade. Porque, se é verdade que sua capacidade de realizar inferências corretas, limitada estritamente a essa função, garante uma ausência do perigo de errar (absque periculo erroris concludamus), não é menos verdade que, fora desse limite, tal modo não constitui, per $s e^{353}$, um meio que permita conhecer perfeitamente ou o melhor possível. Esse é o núcleo básico da inadequação — aqui apresentado quase como uma glosa das definições 1 e 2 da Parte III e da definição 4 da Parte II da Ética ${ }^{354}$ — que

352 A idéia de que, no discurso espinosano, há "personagens conceituais" ou "tipos" que condensam os predicados de certas situações epistêmicas, ou melhor, de certas constitutiones mentis et corporis, foi encontrada e parcialmente desenvolvida no decurso da pesquisa que, sob a orientação de M.S. Chauí, empreendi e vim a defender no mestrado: "Com efeito, [o camponês (rusticus, boer) e a criança (infans, puer)] são tipos ligados à experiência vaga que nos permitem examiná-la em seus desdobramentos particulares. Aquilo que se nos afigura útil nessa tipologia — que, de um modo geral, não é rara nas diversas obras de Espinosa, comportando tipos como 'os comerciantes', 'os matemáticos', 'os filósofos', entre outros - é, pois, o fato de que ela destaca algumas das possíveis constitutiones que o corpo e a mente assumem quando do uso de um ou outro modo de percepção”. Rezende, C.N. (2002) p. 174.

${ }^{353}$ Cf. TIE $§ 28$

${ }^{354} \mathrm{E}$, II, def 4: "Per ideam adaquatam intelligo ideam qua quatenus in se sine relatione ad objectum consideratur, omnes vera idea proprietates sive denominationes intrinsecas habet. EXPLICATIO: Dico intrinsecas ut illam secludam qua extrinseca est nempe convenientiam idea cum suo ideato. / Por 
Espinosa atribui à razão no Tratado da Emenda do Intelecto: esse modo de perceber não é suficientemente seguro (non satis tuta est), a não ser aos maximamente cuidadosos (nisi maxime caventibus).

O Tratado da Emenda, mais do que qualquer outra obra de Espinosa que trate diretamente do assunto, adverte que é preciso ter cuidado com os limites da razão. A partir do que foi examinado aqui, o que entrevejo nessa restrição espinosana à razão é o perigo, nesta última contido, - tão mais perigoso quanto maiores são os êxitos das inferência racionais —, de se degenerar em mera "técnica teórica". Mediante aquela tripla articulação (coisa, propriedade/efeito, nome), esse modo de conhecimento pode se satisfazer com o trabalho no plano de um código de signos biunívocos, fundados na contrapredicabilidade dos propria. Como se pôde ver no exemplo da quarta proporcional, a razão realiza certas operações lógicas sem que, no entanto, sejam realmente efetuados todos os atos mentais em que se baseiam os sinais: " $\rightarrow$ " permanecia vazio e desconhecido, muito embora o resultado fosse alcançado. A maneira racional de conhecer, à diferença da intelectual, corre o risco de limitar-se à aplicação externa de um instrumento de cálculo — de utilidade inquestionável — mas, em essência, indistinta de um competente trabalho administrativo sobre um "jogo de signos”. Portanto, o verdadeiro perigo, aquele contra o qual é mister acautelar-se, isto é, aquele que não se confunde com a possibilidade de errar no resultado, é que a razão se tome e se dê por autônoma, limitando a percepção a essa capacidade de supervisionar o mundo, então reduzido ao objeto $\mathrm{X}$ das operações racionais. Essa limitação consiste, assim, em ficar pela escada (trap), numa atitude que, com ares fetichistas, confundiria o caminho (weg), o meio, com o fim ou, mais ainda, eclipsaria a prevalência deste último com a eficácia daquele primeiro. A propriedade funcionaria, então, como um mediador interposto entre idéia e ideado, por si só tão apto a uni-los quanto a separá-los. No

idéia adequada entendo a idéia que, em si espectada, sem relação com o objeto, possui todas as propriedades ou denominações intrínsecas da idéia verdadeira. EXPLICAÇÃO: Digo intrínsecas para excluir aquela que é extrínseca, qual seja, a conveniência da idéia com seu objeto"; E III, Def 1: "Causam adaquatam appello eam cujus effectus potest clare et distincte per eandem percipi. Inadoquatam autem seu partialem illam voco cujus effectus per ipsam solam intelligi nequit. / Chamo causa adequada aquela cujo efeito pode ser percebido clara e distintamente através dela mesma; inadequada ou parcial chamo aquela cujo efeito não pode ser entendido só através dela". E III, Def 2: "Nos tum agere dico cum aliquid in nobis aut extra nos fit cujus adaquata sumus causa hoc est (per definitionem pracedentem) cum ex nostra natura aliquid in nobis aut extra nos sequitur quod per eandem solam potest clare et distincte intelligi. At contra nos pati dico cum in nobis aliquid fit vel ex nostra natura aliquid sequitur cujus nos non nisi partialis sumus causa. / Digo que agimos quando, em nós ou fora de nós, faz-se algo de que somos causa adequada, isto é, (pela definição precedente) quando a partir de nossa natureza segue-se, em nós ou fora de nós, algo que só por ela pode ser entendido clara ou distintamente. Mas, ao contrário, digo que padecemos quando, em nós faz-se algo ou de nossa natureza segue-se algo do qual não somos senão causa parcial”. 
Tratado espinosano, portanto, a razão, por não ser incondicionalmente boa, é ao mesmo tempo inatacável (concludit; quamvis certa) e criticável (sed non adcequate; non satis tuta est), o que deve inevitavelmente levantar a pergunta pelo tipo de racionalismo que se pode pretender atribuir a Espinosa.

Se "enquanto Descartes não deu a conhecer ética alguma, a obra fundamental de Espinosa é precisamente uma ética" ${ }^{, 355}$, creio que isso não pode significar um desejo supostamente já anunciado pelo mos geometrico — de uma subordinação da ética pela arte da razão (kunst van reden), comprometida com o projeto moderno de dominação da natureza. Bem ao contrário, aí vejo a indicação de que, além do terceiro, há o quarto modo de conhecimento como horizonte filosófico, que eu gostaria de pensar como sendo o de uma racionalidade ou inteligência ética. E isso não porque Espinosa estaria comprometido com um misólogo humanismo renascentista - ainda que, como este, também combatesse a esterilidade formalista da lógica tradicional —, mas porque é na ética que a imanência do produto ao processo se faz, desde sempre, paradigmática: à diferença da poiésis, na práxis o bem agir é o próprio fim. O que, no entanto, é proeminente na teoria espinosana do conhecimento é que a práxis, por conta dessa imanência, forneça a estrutura interna - a fabrica — com que se caracteriza a própria epistême. E este seria, como penso, um bom ponto de partida para compreender as relações constitutivas que se dão entre a ontologia imanentista espinosana e sua teoria do conhecimento, trazendo para primeiro plano a noção de ciência contida da expressão "scientia intuitiva" e a noção de "ação" contida na definição de idéia como "actio mentis".

Em suma, penso que a inadequação da razão, discretamente comentada por Espinosa no texto e nas notas do Tratado da Emenda, deve ser entendida no contraste com aquilo que o mesmo texto já designa como verdadeira ciência e atribui apenas ao quarto modo, capaz de juntar-se ao mundo através de suas construções. Pois, ao nível da racionalidade operatória que aqui se investigou, é evidente que a ciência produzida manipula as coisas sem habitá-las, sem se unir a elas e por elas ser habitada. Tal ciência não sente (gevoelen) e não frui (genieten) a coisa mesma, ela produz índices que funcionam como definições, mas que passam ao largo do que está concretamente dado (datorum numerorum), e trata seu objeto como "objeto em geral" (aliquid), construído sob medida para suportar as atribuições racionais de efeitos ou propriedades.

${ }^{355}$ Hegel (2002) p. 283. 
Mas, caso todo este discurso pareça extemporâneo ao universo seiscentista, como se Espinosa fosse aqui caracterizado como profeta de uma crise que só muito depois viria a ser inventada ${ }^{356}$, respondo que existe, nos limites do que se convencionou chamar de modernidade, coincidente com o tipo dos "matemáticos", um pensamento ao qual convêm perfeitamente os perigosos atributos da racionalidade operatória supra descrita, os quais reduzem a potência cognitiva da idéia à eficácia instrumental de um algoritmo:

"Com efeito, é próprio do astrônomo compor, por meio de uma observação diligente e habilidosa, o registro dos movimentos celestes. E, em seguida, inventar e imaginar as causas dos mesmos, ou melhor, já que não se podem alcançar de modo algum as verdadeiras causas, quaisquer hipóteses que, uma vez supostas, permitam que estes mesmos movimentos sejam corretamente calculados (...). Não é necessário, pois, que essas hipóteses sejam verdadeiras, e nem mesmo verossímeis, bastando apenas que forneçam cálculos que concordem com as observações"357.

"Dizer que salvam-se melhor as aparências de acordo com a suposição de a Terra ser móvel e o Sol imóvel, do que supondo os excêntricos e epiciclos, é falar muito bem - não havendo nenhum perigo nisso e por ser isso suficiente para o matemático. Mas afirmar que na realidade o Sol é imóvel no centro do universo... é arriscar-se não somente a irritar todos os filósofos escolásticos e teólogos, mas também a ofender a Santa fé tornando falsas as Sagradas Escrituras. (...) demonstrar que supondo o Sol imóvel no centro e a Terra se movendo pelo céu, poderemos salvar as aparências, não é o mesmo que demonstrar que assim é na verdade. Acredito que a primeira demonstração pode ser dada, mas tenho as maiores dúvidas em relação à segunda e, em caso de dúvida, não devemos abandonar a interpretação das Sagradas Escrituras dada pelos Padres da Igreja"358.

Julgo que aquilo que, ao longo deste artigo, foi chamado de "eficácia identificatória" da razão, e também, noutros momentos, de "eficácia representativa", tenha o mesmo sentido que possui a adequação empírica preconizada pela

356 "Por que o pensamento contemporâneo vai inventar a idéia de uma "crise da razão"? Afinal, esse tema parece ter sua datação circunscrita à primeira metade de nosso século. Pois se é verdade que, de maneira explícita ou implícita, a noção de "crise" sempre frequientou a história da filosofia, é verdade também que Descartes, por exemplo, não apontava para nenhuma "crise da razão", mas para uma crise das ciências, ciências cujos "princípios incertos" careciam de uma legitimação que a prima philosophia logo, logo lhes viria restituir". Ribeiro de Moura, C.A. (2001), p.185. É preciso declarar que boa parte desta conclusão se pauta, às vezes rente à letra, pela leitura da bibliografia citada nesta nota, bem como pelas objeções, sugestões e críticas que me foram feitas por seu autor quando de meu exame de qualificação para o mestrado. A ele dedico, com admiração e respeito, o presente artigo.

357 Prefácio de Andréas Osiander ao De Revolutionibus de Copérnico, intitulado "De hipotesibus huius operis / Sobre as hipóteses desta obras" In: Loparic (1980), p.57-58.

${ }^{358}$ Carta do Cardeal Bellarmino a Foscarini, em 1615, in: Loparic (1980) p 52. Itálicos meus na tradução. 
epistemologia oficial da inquisição romana — personificada na figura do Cardeal Belarmino e prefigurada pelo prefácio de Andréas Osiander ao De Revolutionibus de Copérnico $^{359}$ - como a única aptidão legítima das teorias científicas. Aliás, entendo que a crítica espinosana ao terceiro modo de perceber deve ser interpretada como uma crítica ao instrumentalismo avant la lettre que necessariamente se estabelece quando é levado em conta somente o traço da convenientia que caracteriza as idéias verdadeiras, sendo, pois, negligenciado o traço da adaquatio, espinosanamente marcado pela presença de certa causa eficiente. Espinosa certamente concordaria com Belarmino quanto ao fato de que a capacidade de uma idéia para predizer e controlar o que se passa com o ideado, embora seja condição necessária ou critério negativo da verdade, não constitui sua condição suficiente ${ }^{360}$. Mas essa capacidade da razão, que é "suficiente para o matemático", não é tudo com o que o homem pode contar. E a alternativa espinosana, recusando-se a contar, por exemplo, com "a interpretação das Sagradas Escrituras dada pelos Padres da Igreja" como critério, propõe algo real e positivo na própria idéia, pelo qual ela se distingue da falsa.

Assim, há de ser tão natural quanto devido o prolongamento deste estudo através de uma investigação do estatuto epistêmico das definições genéticas no confronto com outros modos de pensar, especialmente com as ficções e as hipóteses científicas, trabalhadas por nosso filósofo também no Tratado da Emenda e nalgumas outras obras. Num escopo mais abrangente, isso também leva a pensar na teoria espinosana da

${ }^{359}$ É de notar que o próprio Copérnico, na Carta ao Papa Paulo III, que serve de prefácio ao $D e$ Revolutionibus, se posicione sistematicamente contra aqueles que chama de 'os matemáticos': “ mas o que mais se espera de mim é ouvir dizer como me veio ao pensamento a audácia de, contra a opinião aceite dos matemáticos e, em certa medida, contra o senso comum, imaginar algum movimento da Terra. (...) nenhum outro motivo me levou a pensar num método diferente de calcular os movimentos das esferas do Universo senão o fato de ter verificado que os matemáticos não estão de acordo consigo próprios na investigação de tais movimentos. (...) aqueles que usam círculos concêntricos, embora tenham demonstrado que a partir deles se podem estabelecer alguns variados movimentos, não puderam, apesar disso [isto é, apesar da correspondência obtida], tirar nenhuma certeza que desse segura resposta aos fenômenos. Quanto àqueles que imaginaram os círculos excêntricos, embora pareçam ter dado, em grande parte, solução aos movimentos aparentes com cálculos apropriados (...) não conseguiram descobrir ou concluir um fato de mais interesse, ou seja, a forma do universo e ajusta simetria de suas partes". Itálicos meus. Essa e outras críticas aos "quantos ensinavam Matemática nas escolas" me parecem bons indícios de que, além de apócrifo, o prefácio de Osiander tenha sido adicionado ao $D e$ Revolutionibus à revelia de Copérnico.

${ }^{360}$ Cf. TIE $\S$ : "si aliquis dicit, Petrum ex. gr. existere, nec tamen scit, Petrum existere, illa cogitatio respectu illius falsa est, vel si mavis, non est vera; quamvis Petrus revera existat. Nec hac enunciatio, Petrus existit, vera est, nisi respectu illius, qui certo scit, Petrum existere. $\$ 70$. Unde sequitur in ideis dari aliquid reale, per quod verce a falsis distinguunturl se alguém diz, por exemplo, que Pedro existe mas não sabe que Pedro existe, tal pensamento é, no que respeita a esse [que diz], falso, ou, caso se prefira, não é verdadeiro, embora Pedro verdadeiramente exista. Nem esse enunciado 'Pedro Existe' é verdadeiro a não ser com respeito aquele que sabe com certeza que Pedro existe. $§ 70$ : Donde se segue que se dá na idéia algo de real, pelo qual a idéia verdadeira se distingue da falsa". 
definição, e sua incorporação da causa eficiente, como parte do anseio pela superação de uma lógica meramente extensional.

Mas, o que daqui já resulta para uma caracterização mais ampla do sentido histórico do racionalismo espinosano é que, se este produz, no interior de seu tempo e de seu sistema, uma solicitação de cautela perante a razão, dotada de tão notável congruência com os percalços com que hoje se espreita o próprio racionalismo moderno, deve haver, então, alguma distorção no modo como a imagem desse racionalismo nos chega - ou pelo menos o racionalismo espinosano. Se o racionalismo de Espinosa é "grande", isso se deve, entre outras coisas, ao fato de que essa mesma racionalidade efetivamente construiu e criticou, de dentro de si, a figura de um "pequeno racionalismo", correspondente ao uso inadequado das certeiras inferências da razão. Dessarte, depois desta análise dos termos em que Espinosa pede cautela frente à razão, cumpre levar a sério o emblema espinosano e - ainda hoje — demandar, diante de sua aguda filosofia intelectualista: caute! 
BIBLIOGRAFIA.

Angioni, L. Introdução à teoria da predicação em Aristóteles. Campinas, Ed. Unicamp, 2006.

Aquino, T. L'être et l'essence (le vocabulaire médiéval de l'ontologie; deux traités De Ente et Essentia, de Tomás d'Aquin et de Dietrich de Frriberg; présentés et traduits par Alain de Libera et Cyrille Michon). Paris, Éditions du Seuil, 1996.

Aristóteles Metafísica - Livros VII-VIII. Trad. e Notas Lucas Angioni. Col. Textos Didáticos no. 42. Campinas, IFCH/UNICAMP, 2001.

Arnauld, A. \& Nicole, P. La Logique, ou lart de penser. PUF: Paris, 1965

Aubenque, P. El problema del ser en Aristóteles. Trad. Vidal Peña. Madrid, Taurus, 1987.

Bayle, P. Écrits sur Spinoza. Textes choisies et présentés par Frabçoise Charles-Daubert et Pierre-François Moreau. Paris, Ed. L'Autre Rive / Berg. International Eds., 1983.

Biasutti, F. La Dottrina Della Scienza in Spinoza. Bologna, Pàtron Editore, 1979

Brunschvicg, L. "La Logique de Spinoza: in Revue de Metaphysique et Morale. 1893.

Chauí, M. A Nervura do Real. São Paulo, Companhia das Letras, 1999.

Colli, G. Zenón de Elea. México, Sextopiso Editorial, 2006

Descartes, R. Princípios da Filosofia. Rio de Janeiro, Editora UFRJ, 2002

Descartes, R. Les passions de l'âme, $\mathrm{AT}, \mathrm{XI}$

Dominguez, A. "Las Fuentes de los Cogitata Metaphysica - Analogias Lexicais cons Suarez y Heereboord" in Spinoziana, Richerche di terminogia filosofica e critica testuale, Actes du séminaire international tenu à Rome les 29-30 septembre 1995, a cura di Pina Totaro, Leo S. Olschki editore, Firenze, "Lessico Intellettuale Europeo", LXXII, 1997

Espinosa, B. Korte Verhandeling, Van God, de Mensch, en deszelvs Welstand Breve Trattato su Dio, l'uomo e il suo bene, Introd. Edit. Trad. e Commento di Filippo Mignini. L’Aquila, Japadre, 1986.

Espinosa, B. Spinoza Opera. Im Auftrag der Heidelberger Akademie der Wissenschaft herausgegeben von Carl Gebhardt. Heidelberg, Carl Winters Universitätsbuchhandlung, 1972. 4 Vol. 
Espinosa, B. Traité de la Réforme de L'Entendement. Trad. introd e coment.: Bernard Rousset. Paris, Vrin, 1992.

Espinosa, B. Tratado Breve. Traducción, prólogo y notas de Atilano Domínguez. Madrid. Alianza, 1990

Euclides. Elements. Trad. Sir Thomas L. Heath. Chicago, University of Chicago, 1952.

Floriano, M. Historiola Animi - a experiência intelectual no prólogo do prólogo do Tractatus de Intellectus Emendatione de Baruch Espinosa . Dissertação apresentada ao departamento de Filosofia da Faculdade de Filosofia, Letras e Ciências Humanas para a obtenção do título de Mestre em Filosofia, sob a orientação da Profa. Dra. Marilena de Souza Chauí. Mimeo Biblioteca FFLCH-USP, 2002.

Gainza, M. "A negatividade interrogada: Espinosa entre Bayle e Hegel” in Cadernos Espinosanos XVI. São Pulo, 2007.

Garrett, A. Meaning in Spinoza's Method. Cambridge, Cambridge University Press, 2003

Gueroult, M. Spinoza I - Dieu (Éthique I); Paris, Aubier-Montaigne, 1968

Geroult, M. Spinoza II - L’Âme (Éthique II); Paris, Aubier-Montaigne, 1972

Hegel, G.W.F. Enciclopédia das Ciências Filosóficas em Compêndio (1930)

Hegel, G.W.F. Lecciones sobre la historia de la filosofia. Vol. III. Fondo de Cultura Econômica: México, 2002.

Kant, I. Manual dos cursos de lógica Geral. Trad. Apresentação e notas, Fausto Castilho. Campinas, Editora Unicamp, 2003

Joachim, H. Spinosa's Tractatus de Intellectus Emendatione - A comentary. Oxford, Clarendon Press, 1958

Keale \& Kneale. O desenvolvimento da lógica. Lisboa, Calouste Gulbenkian, 1991

Laudan, L. Teorias do Método Científico de Platão a Mach. Trad. Bathazar Barbosa Filho; in Cadernos de História e Filosofia da Ciência - Série 3, Vol 10, n.2, Jul-Dez 2000

Leibniz, G.W. Escritos Filosóficos. Trad. Ezequiel Olaso, Buenos Aires, Ed. Charcas, 1982.

Levy, L. O autômato Espiritual. Porto Alegre, L\&PM, 1998 
Loparic, J. "Andreas Osiander: Prefácio ao De Revolutionibus Orbium Coelestium" de Copérnico; in: Cadernos de Filosofia e História da Ciência, No. 1, pp. 44-61, 1980.

Macherey, P. Hegel ou Spinoza. Paris, Ed La Découverte, 1990.

Marion, J-L. Sobre a ontologia cinzenta de Descartes - Ciência cartesiana e saber aristotélico nas Regulae. Instituto Piaget, Lisboa, 1990

Mark, T.C. Spinoza's theory of truth. New York, Columbia University Press, 1972

Matheron, A. "Pourquoi le Tratactus de Intellectus Emendatione est-il resté inachevé ?" in Revue des sciences philosophiques et théologiques, No. 1, tome 71, pp. 45-53; Paris, Vrin, 1987.

Matheron, A. "Spinoza and euclidean arithmetic: the exemple of the fourth proportional". In: Spinoza and the Sciences, pp 125-150; org M. Grene \& D. Nails. D. Reidel Publishing Company, 1986

Mignini, F. Introduzione, edizione, traduzione e commento: Breve Trattato su Dio, l'Uomo e il suo Bene, L'Aquila, Japadre, 1986

Mignini, F. (Org.) Dio, L’uomo, La Libertà - Studi sul "Breve Trattato" di Spinoza. Roma, L.U. Japadre Editore, 1990

Moreau, P-F. "Lês príncipes de la lecture de L'Écriture sainte dans lê TTP" in L'Écriture sainte au temps de Spinoza et dans le système spinoziste. Grupe de Rechercehs Spinozistes, Travaux et Documents, $n^{\circ}$. 4, Paris, 1992

Rebollo, Regina A. "Considerações sobre o estabelecimento da medicina no tratado hipocrático Sobre a Arte Médica", in Scientice Studia, Vol. 1, No. 3, 2003, p. 275-97.

Rezende, C.N. "Idéia verdadeira e História"; in: Cadernos Espinosanos, No. II, tomo 2. São Paulo: FFLCH-USP, 1997, pp. 103-133.

Rezende, C.N. Investigação sobre o conceito de emendatio no proêmio do “Tractatus de Intellectus Emendatione” de Espinosa. - Dissertação apresentada ao departamento de Filosofia da Faculdade de Filosofia, Letras e Ciências Humanas para a obtenção do título de Mestre em Filosofia, sob a orientação da Profa. Dra. Marilena de Souza Chauí. Mimeo Biblioteca FFLCH-USP. Abril de 2002.

Rezende, C.N. "A ordem que naturalmente temos". In: Cadernos Espinosanos, No. XI, São Paulo: FFLCH-USP, 2004; pp. 93-110

Ribeiro de Moura, C. A. Racionalidade e Crise. São Paulo: Discurso Editorial, 2001

Ross, D. Aristóteles, Lisboa, Dom Quixote, 1987. 
Ross, D. Plato's theory of ideas. Oxford, Clarendon Press, 1953

Santiago, H. Espinosa e o cartesianismo - O estabelecimento da ordem nos Princípios de Filosofia Cartesiana. São Paulo, Humanitas, 2004

Santos, L.H. "A Harmonia essência" - in A Crise da Razão; Adauto Novaes (Org.). São Paulo, Companhia das Letras, 1996.

Vulliaud, P. Spinoza d'après les livres de as bibliothèque. Paris, Chacornac, 1934. 